\title{
BIOLOGICAL ACTIVITY OF FIBRONECTIN AT THE CELL-MATERIAL INTERFACE
}

\author{
Thesis submitted by \\ Cristina González García \\ To obtain the degree of Dr. Eng. Sci. \\ at the Universitat Politècnica de València \\ Valencia (Spain), 2012
}

Thesis supervisor: Prof. Manuel Salmerón-Sánchez 

A Jorge y a mi familia,

Con mucho cariño 



\section{Contents}

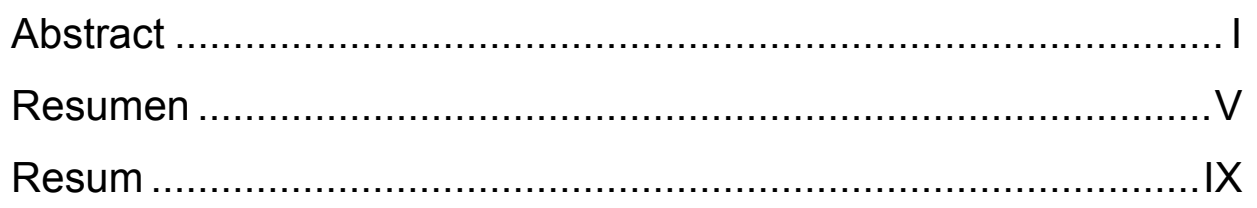

1. Introduction ................................................................ 1

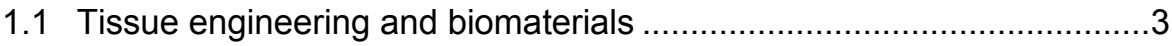

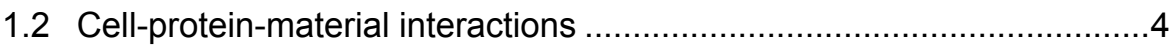

1.3 Extracellular matrix and cell adhesion proteins................................. 6

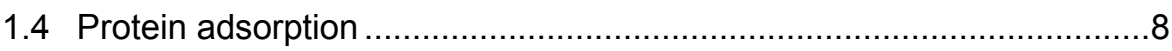

1.4.1 Effect of surface properties on protein adsorption ....................10

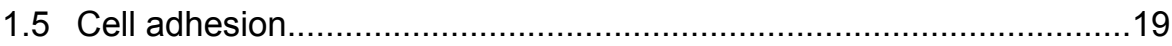

1.5.1 Role of surface properties on cell adhesion ...........................24

1.6 Remodeling of adsorbed proteins ................................................... 30

1.6.1 Reorganization and secretion at the cell-material interface .....30

1.6.2 Proteolytic remodeling at the cell-material interface .................32

1.7 Fibronectin fibrillogenesis..............................................................

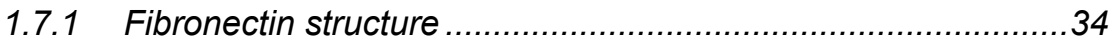

1.7.2 Cell-driven fibronectin fibrillogenesis ......................................36

1.7.3 Cell-free assembly of fibronectin fibrils ..................................40

1.7.4 Material-driven fibronectin fibrillogenesis ..............................40

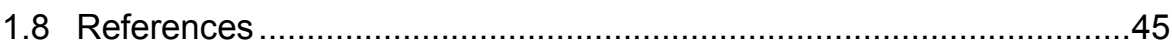

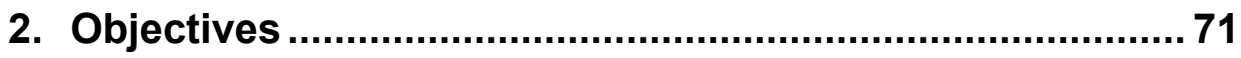

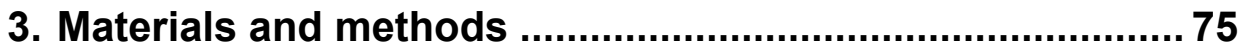

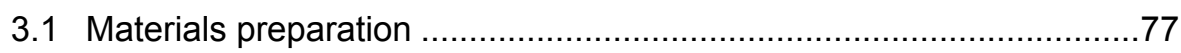

3.1.1 PLLA/PS nanotopographies .............................................. 77

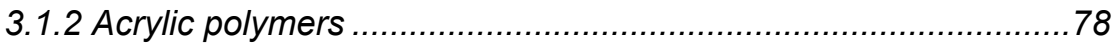




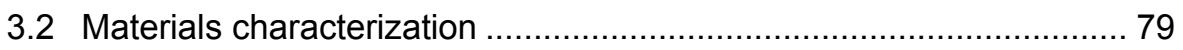

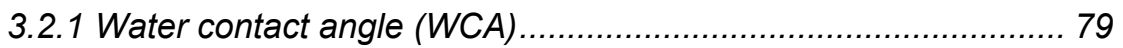

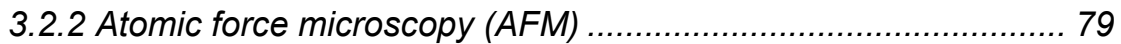

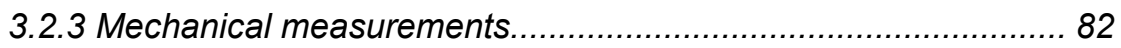

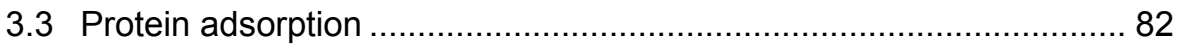

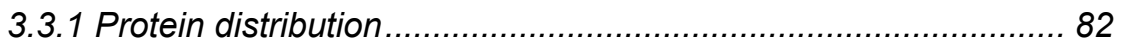

3.3. 2 Protein quantification by radioactivity ...................................... 83

3.3.3 Protein quantification by Western Blot ................................... 85

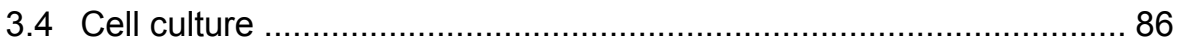

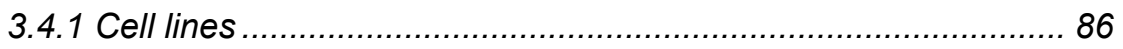

3.4.2 Mesenchymal stem cells (MSCs) ........................................... 86

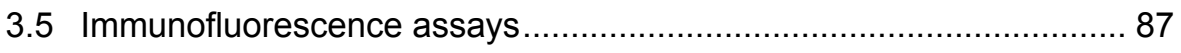

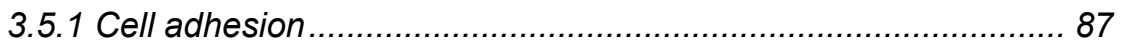

3.5.2 Fibronectin reorganization and secretion ................................ 88

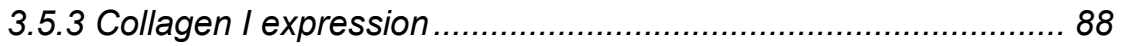

3.5.4 Matrix Metalloproteinase-2 expression (MMP2)....................... 89

3.5.5 Mesenchymal stem cell differentiation .................................... 89

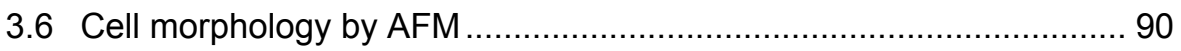

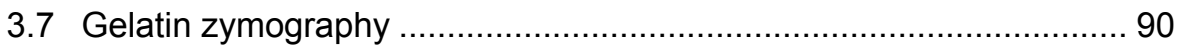

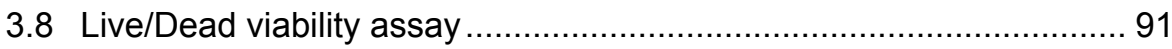

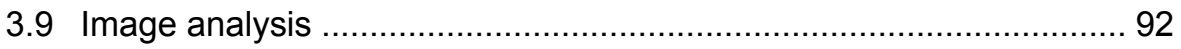

3.9.1 FN distribution on the PLLA/PS nanotopographies................... 92

3.9.2 Western blot bands.............................................................. 93

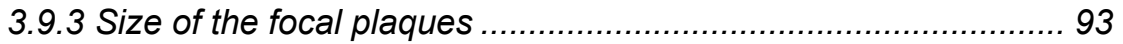

3.9.4 Secreted matrix-associated proteins ........................................ 94

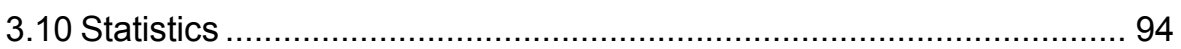

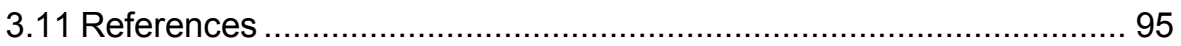


4. Effect of nanoscale topography on fibronectin adsorption and cell response ............................................................. 97

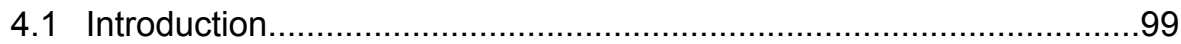

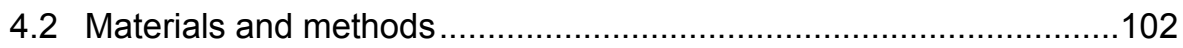

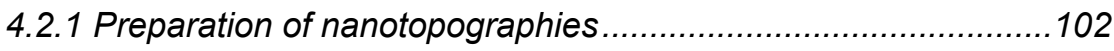

4.2.2 Characterization of nanotopographies ...................................102

4.2.3 Protein adsorption .................................................................103

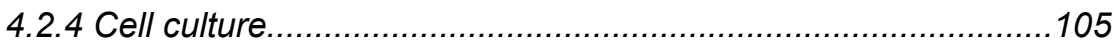

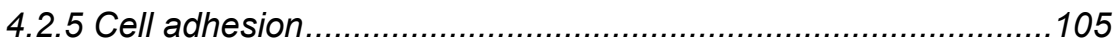

4.2.6 Fibronectin reorganization and FN matrix formation .................106

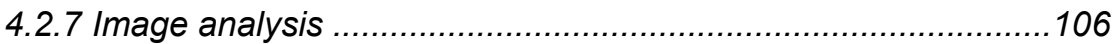

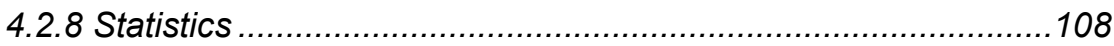

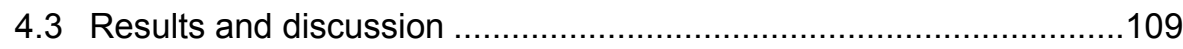

4.3.1 Nanoscale topographies......................................................109

4.3.2 Fibronectin adsorption.........................................................116

4.3.3 Cell adhesion and FN matrix formation ...................................121

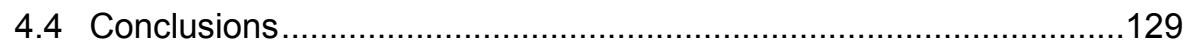

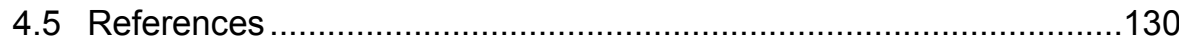

5. Surface mobility regulates cell adhesion and skeletal stem cell differentiation ........................................................... 135

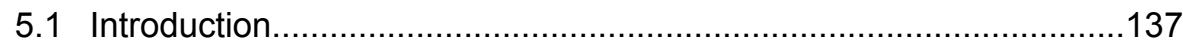

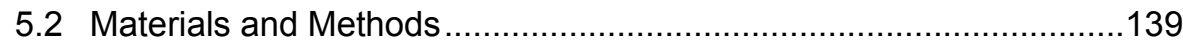

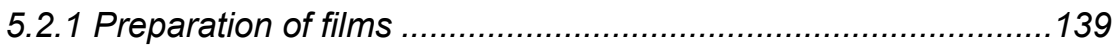

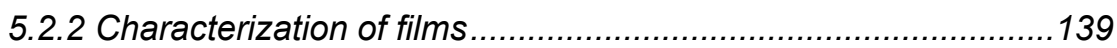

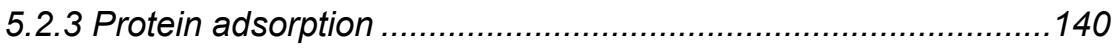

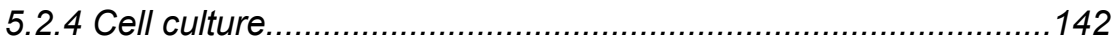

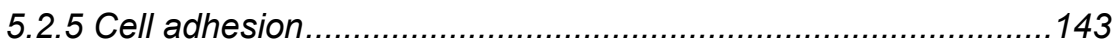

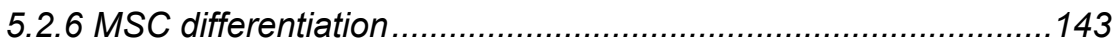

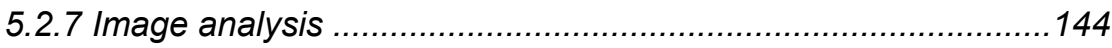

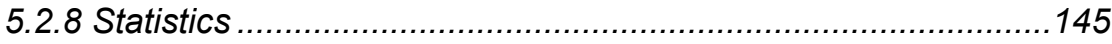




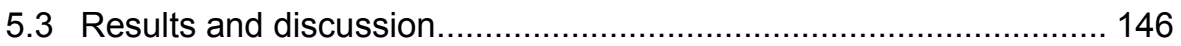

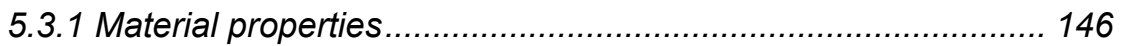

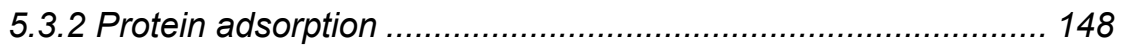

5.3.3 Cell adhesion and skeletal stem cell differentiation ................. 153

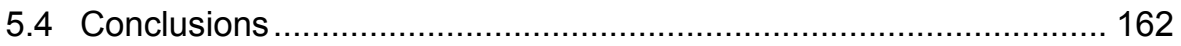

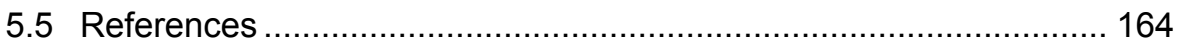

6. Role of vitronectin in fibronectin activity at the cellmaterial interface .............................................................. 171

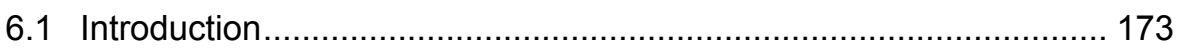

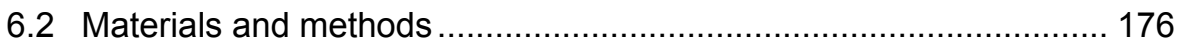

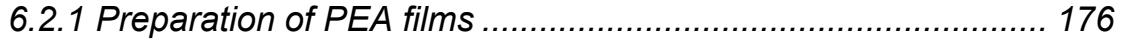

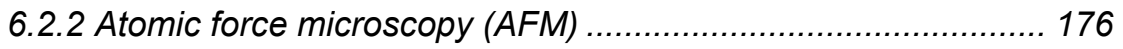

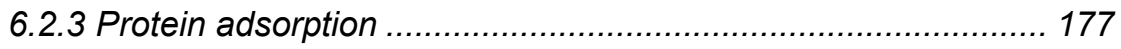

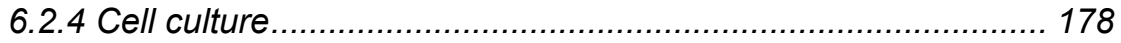

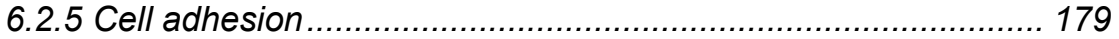

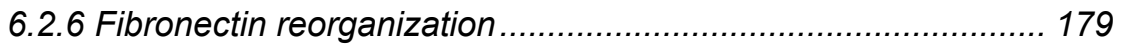

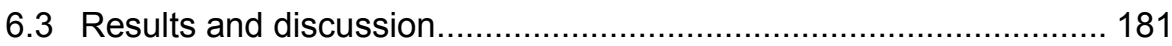

6.3.1 Protein adsorption on PEA surfaces .................................... 181

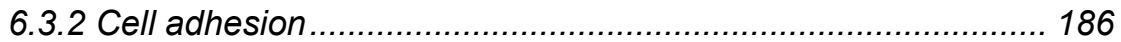

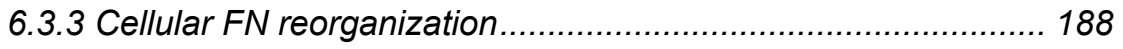

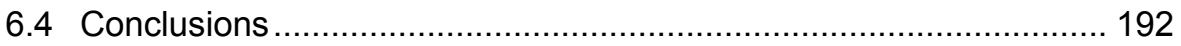

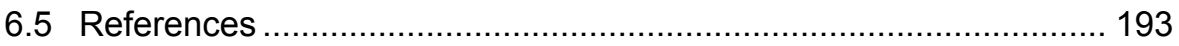

7. Cell-mediated matrix remodeling at the nanoscale .........197

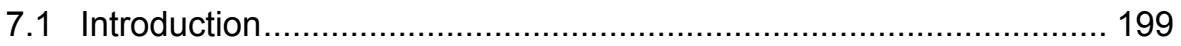

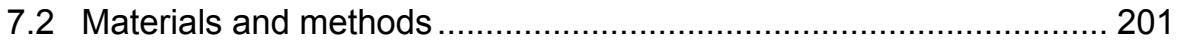

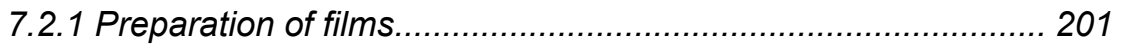

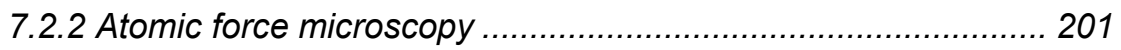

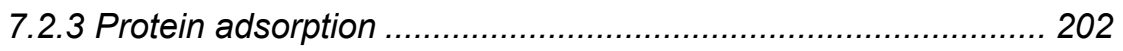

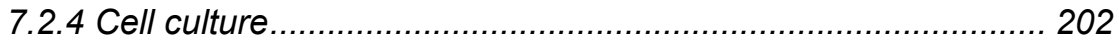


7.2.5 Cell morphology and protein reorganization by AFM ................202

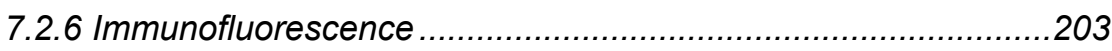

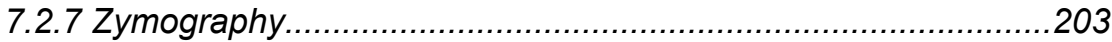

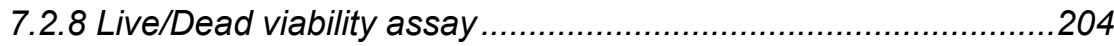

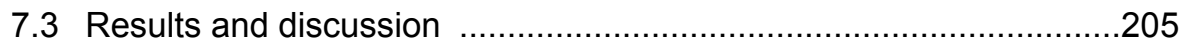

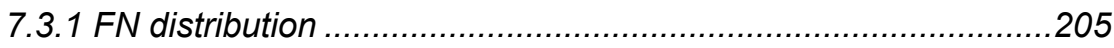

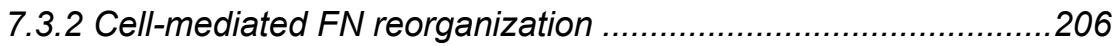

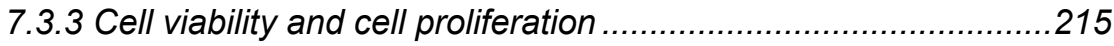

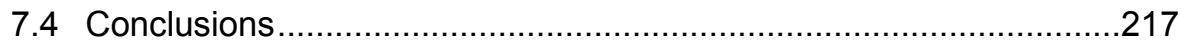

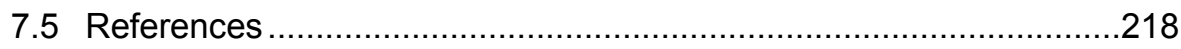

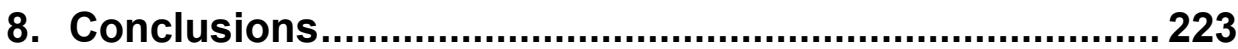

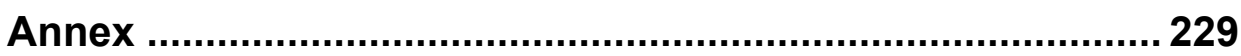

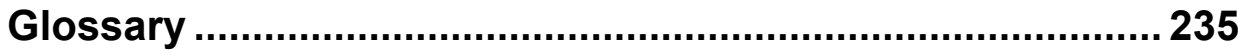

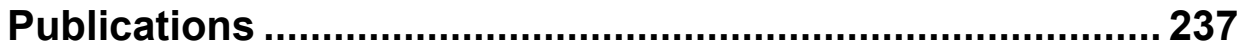





\section{Abstract}

This thesis deals with the biological activity of fibronectin (FN) as interface protein in the interaction between cells and materials. It investigates protein response, in terms of adsorbed amount and conformation, to different physicochemical properties of the material. Moreover, early cell response and cellular functionality are correlated to the state of the protein adsorbed onto the material.

For that, different sets of materials with tailored physico-chemical properties were prepared. FN distribution on the different surfaces was characterized via atomic force microscopy (AFM) and its surface density was quantified by radiolabelling and western blotting. Cell response was evaluated in terms of initial adhesion to the surfaces, and of the subsequent processes of differentiation, proliferation, extracellular matrix reorganization and secretion.

The effect of nanotopography on FN adsorption and cell behavior was investigated using a set of topographies tailored at the nanoscale, obtained by spin casting of poly(L-lactic) acid/polystyrene (PLLA/PS) solutions of different concentrations. PLLA migration to the top of the film during the spin casting process provides PLLA surfaces with nanopits of different sizes (14, 29 and 45 $\mathrm{nm})$. The size of the nanostructure affects the density of adsorbed FN, which is higher on the nanotopography with smaller nanostructures, whereas $\mathrm{FN}$ is evenly distributed through the peaks and valleys of the different nanotopographies when FN adsorption takes place from solutions of concentration of $10 \mu \mathrm{g} / \mathrm{ml}$ or higher (thus including the concentration employed in cell cultures, $20 \mu \mathrm{g} / \mathrm{ml}$ ). With regard to initial cell response, more developed focal adhesions and stronger cell-mediated reorganization of the adsorbed FN layer are observed on surfaces with higher nanostructures (29 and $45 \mathrm{~nm}$ ), resulting in enhanced a greater production and organization of new matrix. 
On the other hand, a family of materials with subtle variations in their chemical composition were employed: acrylic polymers (polymethyl, ethyl, butyl acrylate -PMA, PEA and PBA respectively-) which only differ in the length of the side chain (number of carbons). This change in surface chemistry provides materials of different stiffness and surface mobility, allowing to identify the latter as a new physical parameter able to regulate protein adsorption and cell differentiation. Transition from PMA to PEA drastically alters FN distribution at the material interface, from a globular conformation on PMA to the formation of a well-interconnected FN network on PEA. At increasing surface mobility a FN network is still formed, but with a faster adsorption dynamics (on PBA). Cell adhesion and differentiation to the osteoblastic lineage is enhanced with the surface mobility of the material.

PEA was further studied due to its ability of triggering FN organization into a physiological fibrillar network with enhanced biological activity in the absence of cells. The effect of vitronectin (VN), an extracellular adhesion protein, on FN adsorption and cell response was investigated. FN surface density and distribution onto PEA surfaces is altered when $\mathrm{FN}$ is adsorbed competitively with $\mathrm{VN}$. The presence of $\mathrm{VN}$ during $\mathrm{FN}$ adsorption is likely to provide higher mobility to the FN network, contributing to improve cell-mediated FN reorganization.

FN reorganization in serum-free conditions was studied on surfaces where protein distribution is very different, PMA and PEA, and significant differences are observed. $\mathrm{FN}$ reorganization on PEA was analyzed at the nanoscale via AFM in order to analyze the observed variations in the adsorbed FN layer. A less interconnected FN network is observed around cells, while a denser network is observed on regions far from cells: the occurrence of matrix degradation (among other possibilities) is discussed in order to explain the effect of cells on the protein network in the initial stages of cell adhesion on PEA. 
Finally, preliminary assays were performed via AFM in liquid environment in order to assess fibronectin adsorption and distribution under conditions more similar to physiological ones. 



\section{Resumen}

Esta tesis aborda la actividad biológica de la fibronectina (FN) como proteína de interfase en la interacción célula-material. La tesis investiga la respuesta de la proteína, en términos de cantidad adsorbida y conformación, ante diferentes propiedades físico-químicas del material. Además, se correlaciona la respuesta celular temprana y la funcionalidad celular con el estado de la proteína adsorbida sobre el material.

Para ello se prepararon diferentes series de materiales con propiedades físico-químicas controladas. La distribución de FN sobre las diferentes superficies se caracterizó mediante el uso de la microscopía de fuerza atómica (AFM) y la densidad superficial adsorbida fue cuantificada mediante técnicas de marcado radioactivo y western blot. La respuesta celular se evaluó en términos de la adhesión inicial a las superficies, así como los procesos posteriores de diferenciación, proliferación, reorganización y producción de matriz extracelular.

Se investigó el efecto de la nanotopografía en la adsorción de la FN y el comportamiento celular sobre una serie de topografías controladas en la escala nanométrica, obtenidas mediante el spin casting de soluciones de ácido poli(Lláctico)/poliestireno (PLLA/PS) de distintas concentraciones. La migración del PLLA hacia la superficie del film durante el proceso de spin coating proporciona superficies de PLLA con nanopicos de diferentes tamaños (14, 29 y $45 \mathrm{~nm}$ ). El tamaño de la nanoestrutura afecta a la densidad de FN adsorbida, siendo mayor en la superficie de menor nanotopografía, mientras que la FN se distribuye homogéneamente a través de los picos y valles de las distintas nanotopografías cuando es adsorbida a partir de disoluciones de concentración igual o superior a $10 \mu \mathrm{g} / \mathrm{ml}$ (incluyendo la concentración empleada en los cultivos, $20 \mu \mathrm{g} / \mathrm{ml}$ ). En cuanto a la respuesta celular inicial, se observan adhesiones focales más desarrolladas y mejor reorganización celular de la capa de FN adsorbida en las superficies de mayor topografía (29 and $45 \mathrm{~nm}$ ), lo que resulta en una mayor producción y organización de nueva matriz. 
Por otra parte se empleó una familia de materiales con sutiles variaciones en la composición química: polímeros acrílicos (polimetil, etil y butil acrilato PMA, PEA y PBA respectivamente-) que únicamente difieren en la longitud de la cadena lateral (número de carbonos). Esta variación en la química superficial proporciona materiales de distinta rigidez y movilidad superficial, identificándose esta última como un nuevo parámetro físico capaz de regular la adsorción de proteínas y la diferenciación celular. La transición de PMA a PEA altera drásticamente la distribución de la $\mathrm{FN}$ en la interfase del material, desde una forma globular en el PMA a la formación de una red bien interconectada sobre el PEA, mientras que un aumento mayor de la movilidad superficial mantiene la formación de la red de FN pero con una dinámica de adsorción más rápida (en PBA). La adhesión y diferenciación de células mesenquimales hacia el linaje osteoblástico se mejora con la movilidad superficial del material.

EI PEA fue estudiado en mayor profundidad por su capacidad de inducir, en ausencia de células, la organización de la $\mathrm{FN}$ en una red fibrilar con una actividad biológica mejorada, similar a la fisiológica. Se investigó el efecto de la vitronectina (VN), una proteína de adhesión de la matriz extracelular, en la adsorción de la FN y la respuesta celular. La densidad superficial de la FN y su distribución sobre las superficies de PEA se altera cuando la FN se adsorbe competitivamente con la VN. La presencia de la VN, adsorbida conjuntamente con la FN sobre las superficies, probablemente aporta más movilidad a la red de FN, lo que contribuye a mejorar la reorganización celular de la FN.

Se estudió la reorganización de la $\mathrm{FN}$ en condiciones libre de suero sobre las superficies de PMA y PEA, donde la distribución es muy diferente, observándose diferencias significativas entre ambos materiales. La reorganización de la FN sobre PEA fue analizada a escala nanométrica mediante el AFM con el fin de analizar las variaciones observadas en la capa de FN adsorbida. Se observa una red de FN menos interconectada alrededor de las células y una red de mayor densidad en las regiones superficiales alejadas de la célula, por lo que se discute la existencia de la degradación de la 
matriz (entre otras posibilidades) para explicar el efecto de las células sobre la red de proteína en los primeros estadios de la adhesión celular sobre PEA.

Finalmente se realizaron ensayos preliminares en el AFM en ambiente líquido para evaluar la adsorción y distribución de fibronectina en unas condiciones más similares a las fisiológicas. 



\section{Resum}

Aquesta tesi aborda l'activitat biològica de la fibronectina (FN) com a proteïna d'interfase en la interacció cèlllula-material. La tesi investiga la resposta de la proteïna, en termes de quantitat adsorbida i conformació, davant diferents propietats fisicoquímiques del material. A més, es correlaciona la resposta cel-lular primerenca i la funcionalitat cel-lular amb l'estat de la proteïna adsorbida sobre el material.

Per a això es van preparar diferents sèries de materials amb propietats fisicoquímiques controlades. La distribució de FN sobre les diferents superfícies es va caracteritzar mitjançant l'ús de la microscòpia de força atòmica (AFM) i la densitat superficial adsorbida va ser quantificada mitjançant tècniques de marcatge radioactiu i western blot. La resposta cel-lular es va avaluar en termes de l'adhesió inicial a les superfícies, així com els processos posteriors de diferenciació, proliferació, reorganització i producció de matriu extracel·lular.

Es va investigar l'efecte de la nanotopografia en l'adsorció de la FN i el comportament cel-lular sobre una sèrie de topografies controlades en l'escala nanomètrica, obtingudes mitjançant l'spin càsting de solucions d'àcid poli (Llàctic)/poliestirè (PLLA/PS) de diferents concentracions. La migració del PLLA cap a la superfície del film durant el procés de spin coating proporciona superfícies de PLLA amb nanopics de diferents mides (14, 29 i $45 \mathrm{~nm}$ ). La mida de la nanoestrutura afecta la densitat de FN adsorbida, sent major en la superfície de menor nanotopografia, mentre que la $\mathrm{FN}$ es distribueix homogèniament a través dels pics i valls de les diferents nanotopografies quan és adsorbida a partir de dissolucions de concentració igual o superior a 10 $\mu \mathrm{g} / \mathrm{ml}$ (incloent la concentració emprada en els cultius, $20 \mu \mathrm{g} / \mathrm{ml}$ ). Quant a la resposta cel-lular inicial, s'observen adhesions focals més desenvolupades i millor reorganització cel-lular de la capa de FN adsorbida en les superfícies de major topografia ( 29 and $45 \mathrm{~nm}$ ), el que resulta en una major producció i organització de nova matriu. 
D'altra banda es va emprar una família de materials amb subtils variacions en la composició química: polímers acrílics (polimetil, etil i butil acrilat -PMA, PEA i PBA respectivament-) que únicament difereixen en la longitud de la cadena lateral (nombre de carbonis). Aquesta variació en la química superficial proporciona materials de diferent rigidesa i mobilitat superficial, identificant aquesta última com un nou paràmetre físic capaç de regular l'adsorció de proteïnes i la diferenciació celllular. La transició de PMA a PEA altera dràsticament la distribució de la $\mathrm{FN}$ a la interfase del material, des d'una forma globular en el PMA a la formació d'una xarxa ben interconnectada sobre el PEA, mentre que un augment major de la mobilitat superficial manté la formació de la xarxa de FN però amb una dinàmica d'adsorció més ràpida (en PBA). L'adhesió i diferenciació de cèl/lules mesenquimals cap al llinatge osteoblàstic es millora amb la mobilitat superficial del material.

EI PEA va ser estudiat en major profunditat per la seva capacitat d'induir, en absència de cèl-lules, l'organització de la FN en una xarxa fibrilllar amb una activitat biològica millorada, semblant a la fisiològica. Es va investigar l'efecte de la vitronectina $(\mathrm{VN})$, una proteïna d'adhesió de la matriu extracel/lular, en l'adsorció de la FN i la resposta cel-lular. La densitat superficial de la FN i la seva distribució sobre les superfícies de PEA s'altera quan la FN és adsorbida competitivament amb la VN. La presència de la VN, adsorbida conjuntament amb la FN sobre les superfícies, probablement aporta més mobilitat a la xarxa de $\mathrm{FN}$, el que contribueix a millorar la reorganització cel·lular de la FN.

Es va estudiar la reorganització de la $\mathrm{FN}$ en condicions lliures de sèrum sobre les superfícies de PMA i PEA, on la distribució és molt diferent, observant diferències significatives entre ambdós materials. La reorganització de la FN sobre PEA va ser analitzada a escala nanomètrica mitjançant l'AFM per tal d'analitzar les variacions observades a la capa de FN adsorbida. S'observa una xarxa de FN menys interconnectada al voltant de les cèl-lules i una xarxa de major densitat en les regions superficials allunyades de la cèl-lula, de manera que es discuteix l'existència de la degradació de la matriu (entre altres 
possibilitats) per explicar l'efecte de les cèl/lules sobre la xarxa de proteïna en els primers estadis de l'adhesió cel·lular sobre PEA.

Finalment es van realitzar assajos preliminars amb l'AFM en ambient líquid per a avaluar l'adsorció i distribució de fibronectina en unes condicions més similars a les fisiològiques. 



\section{Introduction}





\subsection{Tissue engineering and biomaterials}

The loss or failure of an organ or tissue is one of the most frequent, devastating and costly problems in human health care, which has been tried to be solved through different approaches, such as transplants, autologous grafts, prostheses and tissue regeneration.

Nowadays, regenerative medicine employs tissue engineering techniques to solve many diseases and degenerative processes of tissues and organs. Tissue engineering is an interdisciplinary area that strives to repair the structure and function of damaged or dysfunctional tissues, by engineering advanced material-based systems [1]. These materials are employed to develop substrates or scaffolds with appropriate characteristics for cell adhesion and proliferation and to allow cells to develop their functions, thereby acting as artificial extracellular matrices able to trigger the cell regeneration. Therefore, these material substrates are designed according to the biological characteristics and mechanical requirement of the target tissue for reparation. Their interface with cells and the implant site must be clearly understood so that the interface can be optimized.

Biomaterials are characterized by their ability to exist in contact with tissues of the human body and develop a specific biological function without causing a rejection reaction or causing any harm to that body [2]. Polymeric biomaterials present many possibilities, comparing to biomaterials of a metallic or ceramic nature, due to the variety of compounds and the possibility of manufacturing in many different ways with well defined characteristics and different conformations. Moreover, they can be classified according to their synthetic or natural origin, or according to their ability of degradation, for temporal or permanent applications. Biodegradable materials are eliminated in a natural way after completing its function, which is an advantage over the use of prosthesis, since they avoid posterior surgeries for their replacement or removal 
and any stress problems at the site of implantation associated with permanent and rigid metallic implants [3].

Although tissue engineering uses different strategies to promote regeneration, the principle of tissue engineering is based on cell extraction from the patient, their expansion in vitro, their culture on a biomaterial designed with specific physico-chemical properties, able to direct cellular behaviour and function, and the posterior implantation in the site to be repaired. Cell adhesion on material surface is the first step of the regeneration process and plays a fundamental role in subsequent cell growth, differentiation, viability and phenotype expression [4].

\subsection{Cell-protein-material interactions}

Cell adhesion and subsequent response to a synthetic material is mediated by a layer of extracellular matrix (ECM) proteins, which adsorb onto its surface upon contact with physiological fluids in vivo or culture medium in vitro. In fact, cells cultured on a material or responding to a foreign implant, do not get in direct contact with the substrate, but instead interact with the proteins that have previously adsorbed onto its surface [5-22].

The initial cell-material interaction usually involves the adsorption of proteins such as fibronectin (FN), vitronectin (VN), fibrinogen (FG), representing the socalled soluble matrix proteins in the biological fluids [17]. Upon longer contact with tissues many other extracellular matrix (ECM) proteins, such as collagens and laminins, will also associate with the surfaces, affecting the cellular interaction. Cells recognize specific sequences of these matrix proteins via a family of trans-membrane proteins - integrins - that provide links between the ECM and the actin cytoskeleton [23]. When integrins are occupied, they cluster and develop an aggregate of different proteins, the so-called focal adhesions, which actually anchor the cell to the substrate. Focal adhesions are supramolecular complexes that contain various structural proteins such as 
vinculin, talin, $\alpha$-actinin, and signaling molecules, including FAK, Src and paxilin, which attach the cells to the surface and trigger the subsequent cellular response [24-25]. Thus, the initial cell-material interaction is a complex multistep process consisting of early events, such as adsorption of proteins, followed by cell adhesion and spreading, and late events, related to cell growth, differentiation, matrix deposition and cell functioning. To measure and to quantify some of these parameters comprise the classical approach to characterize the cellular biocompatibility of materials [26].

Even if the cell material interaction is not a direct one, but it is mediated by ECM proteins adsorbed on the substrate; it is said that cells response to different kinds of surface properties: chemical, topographical and mechanical [27]. The surface properties of the materials determine protein adsorption, and the state of adsorbed proteins (conformation, surface density and strength of interaction) affects the type and extent of the cell response, eventually determining the biocompatibility of the system [19].

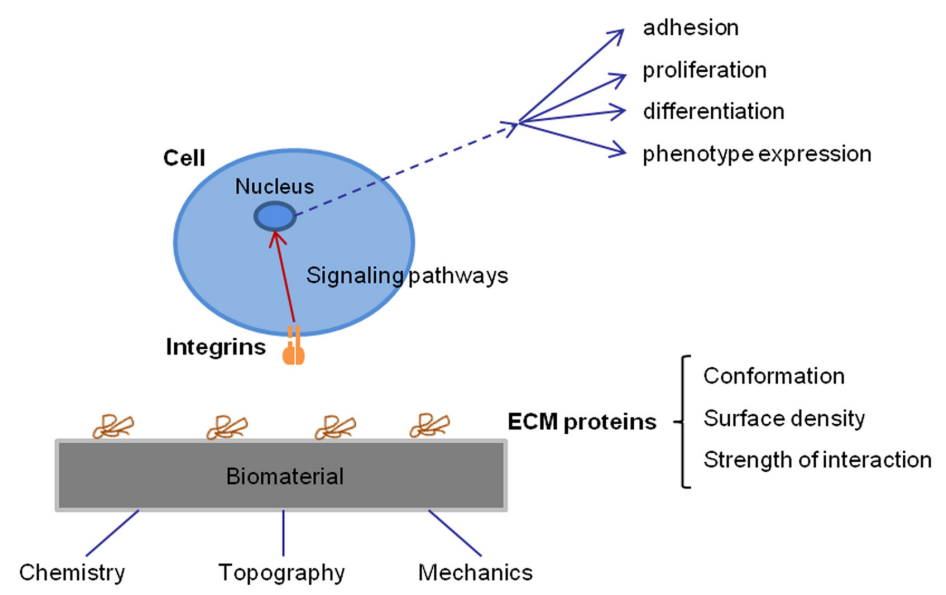

Figure 1.1 Cell-protein-material interaction. Physico-chemical properties of materials influence protein adsorption (conformation, surface density and strength of interaction). Adsorbed ECM proteins are recognized by cell surface receptors (integrins) which trigger the subsequent cell response. 


\subsection{Extracellular matrix and cell adhesion proteins}

The extracellular matrix (ECM) is a dynamic and heterogeneous meshwork of fibrillar and non-fibrillar components that provide an active microenvironment for cell adhesion, differentiation, migration and proliferation. It acts as a reservoir for growth factors and fluids and can be assembled into elaborated structures participating in basement membranes and providing a scaffold for tissue organization. Moreover, it regulates numerous cell functions by activating multiple signaling pathways at adhesion sites. ECM is composed of structural proteins such as collagens, elastin, which provide strength and flexibility to the matrix; proteoglicans (protein-polysaccharide complex) that constitute the matrix in which are inserted structural molecules; and other glycoproteins such as fibronectin and laminin, which anchor the cells to the matrix. The ECM components are secreted by cells as non-functional protein units, which are assembled into functional supramolecular structures in a highly regulated manner [28-30]. The ECM also plays an important role in morphogenic processes critical for development, regeneration, and healing. Defects in assembly stops embryogenesis, deranged assembly promotes scarring, tumorigenesis and fibrotic disease; delayed assembly provokes birth defects, chronic wounds and skeletal malformations [31].

Among the proteins of the ECM that mediate cell adhesion and whose interaction with synthetic materials has been the object of intensive studies, the most significant ones include fibronectin, fibrinogen, laminin, vitronectin, and collagens.

Fibrinogen $(F G)$ is a large, complex, fibrous glycoprotein (328 kDa) normally present in human blood plasma; it consists of six polypeptides organized into a trinodular structure [32]. FG is essential for many biological functions, including haemostasis, wound healing, inflammation, and angiogenesis; in particular, it mediates platelet adhesion. Laminins (LN) are a family of large multi-domain glycoproteins $(900 \mathrm{kDa})$ which consist on trimeric molecules of $\alpha, \beta$, and $\mathrm{y}$ 
chains [33]. LN are important components of basement membranes, where they provide interaction sites for many other constituents, including cell surface receptors; moreover, they play an important role in neural cell migration, differentiation, and neurite growth. Vitronectin $(\mathrm{VN})$ is a multi-functional adhesive glycoprotein found in the circulation and in different tissues, with a molecular weight of $75 \mathrm{kDa}$. It is involved in several physiological and pathological processes including haemostasis, angiogenesis, rheumatoid arthritis, and tumor cell invasion; and it regulates proteolysis initiated by plasminogen activation [34]. VN also contributes to cell adhesion, migration and integrin-mediated signal transduction. Collagen $(\mathrm{Col})$ is the major insoluble fibrous protein in the ECM and in the connective tissue; it exists in different isotypes, the most abundant ones being types I, II, III, and IV [35]. Each collagen molecule is composed of three long chains which are tightly twisted together into a triple helix. The unique properties of each type of collagen are due mainly to segments that interrupt the triple helix and that fold into other kinds of three-dimensional structures. Like other ECM proteins, collagen is recognized by the cells via integrins, and this interaction triggers cell response.

Fibronectin (FN) is a ubiquitous glycoprotein and the core component of the ECM. It is found in a soluble form in blood and other extracellular fluids, and in an insoluble form in connective tissues and attached to cell surfaces. It is synthesized by adherent cells which then assemble it into a fibrillar network in an integrin binding-dependent mechanism [36]. The assembly of FN matrix is the initial step which orchestrates the assembly of other ECM proteins and promotes cell adhesion, migration and signaling [29, 31]. FN matrix also controls the availability of growth factors [37]. Therefore, it has an important role for normal cell adhesion and growth and plays a critical role in early development [38].

The importance of $\mathrm{FN}$ as a mediator of cell adhesion to a substrate was early recognized [39]. Many studies have showed the role of FN in triggering cell adhesion and regulating cellular and phenotype expression on different 
material surfaces [40-43]. The present work is focus on investigating the biological activity of fibronectin as mediator protein of cell-material interactions. Its structure and functions are described in more detail below.

\subsection{Protein adsorption}

Protein adsorption on a material surface is the initial event that occurs when a material comes into contact with a biological environment. Understanding the interaction between proteins and material surfaces is critical, and the control of this interaction is an important factor for consideration in the design of biocompatible surfaces. The status of the adsorbed proteins, namely their concentration, distribution, conformation and strength of interaction, affects the type and extent of the cell response, eventually determining the biocompatibility and biofunctionality of the system [5-7, 9-16, 19-22].

The adsorption of proteins onto the surface of a biomaterial from the surrounding fluid phase is a complex, dynamic, energy-driven process, controlled by the solution conditions (e.g., temperature, $\mathrm{pH}$, salt concentration), protein properties (e.g., size, conformation, charge distribution, strength of intramolecular bonds) and material surface properties (e.g., chemistry, surface energy, charge, topography) [6].

Among external parameters that influence protein adsorption, temperature has an effect on equilibrium state and the kinetics of adsorption. The amount of adsorbed proteins generally increases at elevated temperatures. The major driving force of protein adsorption is the entropy gain arising from the release of surface adsorbed water molecules and salt ions and from structural rearrangements inside the protein [44-45]. The $\mathrm{pH}$ determines the electrostatic state of proteins. When $\mathrm{pH}$ equals the isoelectric point $(\mathrm{pl})$ of a protein, the numbers of negative and positive charges are in balance resulting in a net neutral molecule. At lower $\mathrm{pH}$ conditions $(\mathrm{pH}<\mathrm{pl})$ proteins are positively charged whereas at higher $\mathrm{pH}$ conditions $(\mathrm{pH}>\mathrm{pl})$ proteins are negatively charged. 
Electrostatic protein-protein repulsions are minimized at the isoelectric point allowing higher packing densities on the surface [46-47]. Ionic strength (concentration of dissolved ions) influences the electrostatic interactions between charged entities, which are shorter as the ionic strength increases [48].

Proteins are complex molecules that typically exhibit different affinities in different regions of their surface, depending on the local composition of amino acid residues. These individual domains can be of hydrophobic, hydrophilic, positively, or negatively charged nature [49-51]. In solution, proteins rotate freely whereas on a surface each protein adopts a certain orientation determining which part of the molecule interacts with the surface and which part is exposed to the bulk solution. The favored orientation of a protein on the surface is the one that minimize its free energy resulting from attractive coulomb and van-der-Waals interactions, hydrogen bonds, and the entropy gain of solvent molecules [49-51]. Therefore, its orientation and conformation will depend on the physico-chemical properties of the substrate surface, determining the accessibility of interaction domains with cell receptors.

After hydration of the substrate, the proteins of the fluid phase are transferred towards the interface due to diffusion or under a force field, and eventually get attached to the material surface. Small proteins diffuse faster than larger ones and are the dominating species in the early adsorption stage. Depending on the relative strength of the initial attachment, these macromolecules can stay adsorbed or be displaced over time by other proteins with higher affinity for the surface (Vroman effect) [13]. Larger proteins typically bind stronger to the surface because of a larger contact area [52]. Hence, adsorption from protein mixtures is a selective phenomenon that leads to enrichment of the interface in particular proteins $[11,13,19]$. In addition to the time-dependent compositional changes, those proteins that finally remain on the surface may undergo conformational and orientational rearrangements to increase the contact area with the substrate and minimize the interaction energy with it; moreover, as their concentration on the surface increases, they may go 
through ordering transitions because of the protein-protein interaction [19, 5354]. Adsorption rates can be increased as a result of increasing surface coverages [55-57]. The diffusion of a protein in close proximity to the surface is more like to adsorb if there are already pre-adsorbed proteins, and its adsorption rate is higher.

Finally, cells make contact with the protein-coated surface and interact with it through transmembrane receptors, usually integrins, facilitating cell anchorage to the material and triggering the subsequent cellular response. Hence, the nature and the bioactivity of the adsorbed layer of proteins dictate the initial cellular response and, eventually, the fate of a synthetic material when it is introduced in a biological environment.

\subsubsection{Effect of surface properties on protein adsorption}

The formation of the right adhesive layer of protein onto a biomaterial surface is critical in the biocompatibility of a material, thus it is necessary to control the biological activity of adsorbed proteins by tailoring the surface characteristics of the material, through chemical, topographic or mechanical cues.

\section{Surface chemistry}

Modification of surface chemistry is the most direct way to influence protein adsorption [11-12, 14]. In fact, surface chemistry plays an important role in determining the conformation of adsorbed proteins as well as the rates of adsorption and the amount and composition of the adsorbed protein layer through interactions between the functional groups on the substrate and those of the proteins themselves. Hence, by tailoring the functional groups available at the material surface, and therefore modifying the surface properties (in terms of wettability, surface charge, or free energy), it is possible to modulate the affinity of ECM proteins for the surface. 
Even though it is well accepted that certain functional groups enhance protein/surface interactions $[9,11]$, at present a comprehensive knowledge and consequent methodology that allows a full control of protein adsorption is still lacking [11]. It is generally acknowledged that hydrophobic surfaces tend to adsorb more serum proteins $[9,58]$, whilst hydrophilic ones tend to resist protein adsorption [9]; surface charges are also a significant factor for protein adsorption [9, 22]. Nevertheless, exceptions exist to these general rules, as the protein/material interaction ultimately depends on the specific kind of substrates that are studied and on the proteins involved in the adsorption process.

Fibronectin, $(\mathrm{FN})$ is adsorbed in greater amounts onto hydrophobic model surfaces than onto hydrophilic ones. For instance, higher FN density was adsorbed on non-wettable polystyrene (PS) bacteriological dishes versus wettable oxidized-PS tissue culture dishes [42], or hydrophobic silanized glass versus hydrophilic glass [59]. Hydrophobic polysulfone (PSf) surfaces modified by covalent grafting of polyethylene glycol (PEG) at increasing concentrations yielded a family of surfaces where $\mathrm{FN}$ adsorption decreased gradually with increasing wettability [43]. Similarly, FN adsorption was lower onto hydroxyl $(\mathrm{OH})$ terminated self assembly monolayers (SAMs), than onto carboxylic acid $(\mathrm{COOH})$, or amine $\left(\mathrm{NH}_{2}\right)$, or methyl $\left(\mathrm{CH}_{3}\right)$ terminated SAMs [40]; in this model system, $\mathrm{FN}$ adsorption saturated at higher levels for the positively charged $\mathrm{NH}_{2}$ SAMs compared to the neutral $\mathrm{CH}_{3}$ and to the negatively charged $\mathrm{COOH}$ SAMs. The recombinant fragment of $\mathrm{FN}, \mathrm{FNIII}_{7-10}$, presented an analogous adsorption behavior on the same model surfaces [60]. Wettability was also found to play an important role in $\mathrm{FN}$ adsorption to titanium dioxide $\left(\mathrm{TiO}_{2}\right)$ surfaces, with greater protein adsorption on the more hydrophobic surfaces (butanol-treated $\mathrm{TiO}_{2}$ ) [61]. FN surface density was also higher on hydrophobic poly(dimethylsiloxane) (PDMS) compared to activated hydrophilic PDMS [62].

However, FN adsorption followed an opposite trend in other systems, with higher FN adsorption on the more hydrophilic surfaces. Higher amount of FN was adsorbed on a hydrophilic surface of pure titanium with a titanium oxide 
layer formed in a $\mathrm{H}_{2} \mathrm{O}_{2}$ solution $\left(\mathrm{TiO}_{2} \mathrm{cp}\right.$ ) compared to the more hydrophobic surface of $\mathrm{TiO}_{2}$ sputtered on $\mathrm{Si}\left(\mathrm{TiO}_{2} \mathrm{sp}\right)$ [63]. Moreover, $\mathrm{FN}$ molecules were more strongly attached to the former surface as indicated by exchangeability studies. FN adsorption, either from a pure solution or from serum, was greater on hydrophilic $\mathrm{COOH}$ SAMs, followed by OH SAMs; and the lowest amount of protein adsorption was found onto $\mathrm{CH}_{3}$ SAMs [64], showing an opposite trend to other studies with these model surfaces [40]. In the system based on the copolymerization of ethyl acrylate (EA) and hydroxyethyl acrylate (HEA), where the surface density of $-\mathrm{OH}$ groups can be varied without modifying any other chemical functionality, the highest $\mathrm{FN}$ adsorption occurred on the most hydrophilic substrate [65]. Nevertheless, the amount of adsorbed FN was not found to depend monotonically on the $-\mathrm{OH}$ density. Chitosan membranes with decreasing degree of acetylation (DA) gave place to surfaces with increasing hydrophilicity, due to the higher surface concentration of amine functionalities, where FN adsorption was higher [66]. Furthermore, when FN was adsorbed from serum, the amount of adsorbed $\mathrm{FN}$ was threefold higher with respect to the tissue culture PS control, indicating that in the presence of competitive proteins chitosan is more specific toward FN adsorption than tissue culture PS. The role of surface charge in FN adsorption was investigated by using multilayer films obtained via layer-by-layer ( $\mathrm{LbL}$ ) assembly and composed of polymers of biological origin (poly(L-lysine) (PLL) and dextran sulfate (DS) [67]: FN adsorbed in greater amounts and more strongly to positively charged and less hydrated polycation-terminated films.

In the case of FG, most studies which have addressed the dependence of the amount of FG adsorption on surface wettability, have converged in an increase of adsorbed amount with increasing surface hydrophobicity [68-72]. For instance, FG adsorption was investigated on the system based on copolymers of ethyl acrylate and hydroxyethyl acrylate, and the adsorbed amount was found to decrease as the surface fraction of $\mathrm{OH}$ groups increased [72]. The adhesion force of FG to the substrate was found to follow a similar 
trend [68]. Only a few works found different trends of FG adsorption, where surface hydrophobicity did not dictate FG/surface interactions [73]. Finally, the effect of surface charge on FG adsorption has been studied [74], and FG adsorption tended to be lower in samples with lower zeta-potential, where charge repulsion was higher.

Other important ECM proteins, such as VN and Col IV, have been shown to adsorb in greater amounts on more hydrophobic surfaces [75-76]. Surface wettability has also been found to affect competitive protein adsorption from multi-component mixtures, such as plasma serum. Alterations in surface hydrophobicity were found to modulate the composition of the protein layer [77]. Whilst total protein adsorption from serum-containing cell culture medium decreased with increasing hydrophobicity, FN adsorption followed the opposite trend. When a binary mixture of FN and albumin was adsorbed onto plasmatreated surfaces with a wide range of wettability, $\mathrm{FN}$ adsorbed much more on hydrophilic surfaces, while albumin dominated on hydrophobic ones in a competing mode [78]. Similarly, FN competitively adsorbed from binary solutions with albumin was shown to adsorb in greater amount onto $\mathrm{TiO}_{2} \mathrm{cp}$ (more hydrophilic) than $\mathrm{TiO}_{2} \mathrm{sp}$ substrates [79]. Hydroxyapatite (HAP) was shown to adsorb more FN and VN from serum than two commonly used hardtissue materials, commercial pure titanium and $316 \mathrm{~L}$ stainless steel [80]. Finally, coating titanium with chitosan was found to selectively enhance adsorption of $\mathrm{FN}$, due to the positive charge present on the coated samples [81].

Besides the amount and type of adsorbed proteins, surface chemistry is known to affect the conformation and orientation of the proteins upon adsorption, determining their biological activity. It is generally thought that hydrophilic substrates induce less modification in the conformation of adsorbed proteins; thus, proteins would tend to retain a more active conformation on hydrophilic substrates as compared to the one that they adopt upon adsorption onto hydrophobic substrates [22]. 
In the case of $\mathrm{FN}$, several studies have confirmed that while hydrophilic, negatively charged surfaces promote the extension of its dimer arms, in a conformation that favors the binding of antibodies against cell-adhesive epitopes, hydrophobic surfaces promote the disruption of its secondary structures, negatively affecting cell response [40, 42, 59-60, 62, 82-89]. FN adopted a more favorable conformation on wettable oxidized-PS tissue culture dishes than on hydrophobic PS [42]. FN conformation onto SAMs with different functionalities was studied, and was observed that FN underwent greater loss of $\beta$-sheet structure on hydrophobic methyl or bromide terminated SAMs, than on hydrophilic surfaces [85]; the same effect was observed upon adsorption of FN onto hydrophobic PS [87]. FN adsorbed onto hydrophilic PS in a conformation that favored the exposition of the RGD domain as compared to hydrophobic PS [84]. Hydrophilic surfaces (OH-SAM) induced the least amount of structural change in $\mathrm{FN}$ or in the recombinant fragment $\mathrm{FNIII}{ }_{7-10}$, while hydrophobic $\mathrm{CH}_{3}$ SAM provokes the largest structural changes $[40,60]$. FN molecules adsorbed on hydrophilic surfaces (silica) had an elongated structure, whereas on hydrophobic ones (methylated silica) compact structures were more frequently observed via AFM; on the other hand, mica surfaces displayed both compact and elongated protein structures [86]. Further studies confirmed that surface wettability affects the exposure of the flexible $\mathrm{FNIII}_{10}$ fragment containing the RGD sequence, which seems to be masked in the structure adopted by FN onto non-sulfonated (hydrophobic) styrene/methyl methacrylate copolymer surface [82-83]. However, upon adsorption on the system based on copolymers of ethyl acrylate and hydroxyethyl acrylate, FN assumed an extended conformation on the more hydrophobic surfaces, where a protein network, characterized by FNFN interactions, was found [65, 90-91]. This phenomenon was strongly dependent on the surface chemistry and only took place for substrates with hydroxyl fractions lower than 0.7 , while disperse (micro) aggregates of the protein were observed on more hydrophilic substrates. A similar adsorption behavior on these substrates was demonstrated for the recombinant fragment $\mathrm{FNIII}_{7-10}$; moreover, $\mathrm{FNIII}_{7-10}$ adsorbed on PEA proved to have higher 
bioavailability of cell adhesion domains, including RGD, with respect to control glass.

Also in the case of FG, surface wettability has been shown to affect its conformation and biological activity [69-70, 72, 92-97]. Globular conformations were observed on hydrophilic mica, whereas the trinodular structure of the extended molecule was clearly observed on hydrophobic graphite [96]. The formation of a FG layer on hydrophobic surfaces proceeded via network formation and propagation, involving protein-protein interactions, while on hydrophilic surfaces FG layer grew through a homogeneous increase in nucleation sites [94]. The footprint of a FG molecule is larger when adsorbed on a hydrophobic surface (graphite) than on a hydrophilic one (mica) [92-93] and the spreading of FG increases with the hydrophobicity of the surface [95]. Nevertheless, other authors have found the FG trinodular conformation on both surfaces [97]. In the case of the system based on copolymers of ethyl acrylate and hydroxyethyl acrylate, the formation of a FG network occurred on pure PEA $\left(-\mathrm{OH}_{0}\right)$, but the co-continuity of the protein network was lost when small amounts of $\mathrm{OH}$ were introduced in the system $\left(-\mathrm{OH}_{10}\right.$ and $\left.-\mathrm{OH}_{20}\right)$ [72]. When VN was adsorbed on this family of substrates, isolated globular-like $\mathrm{VN}$ molecules were observed on the surfaces with higher $-\mathrm{OH}$ density; as the fraction of hydroxyl groups decreased, aggregates of 3-5 VN molecules could be observed, and VN activity was enhanced [75]. When LN was adsorbed on the same set of substrates, protein molecules showed globular-like morphology on the hydrophilic PHEA and gradually extended as the amount of $-\mathrm{OH}$ groups on the surface diminished, up to a point in which the protein conformation tended again to a more compact, less extended conformation [98]. Also in the case of collagen, surface chemistry has been shown to affect protein conformation and organization upon adsorption [76, 99-101]. Different adsorptions patterns weres observed for collagen I, III and IV. 


\section{Surface Topography}

With regard to the effect of surface topography on protein adsorption, microscale topographic features are too large for individual proteins to "observe"; on the other hand, nano-topographic structures are closer to the size scale of protein molecules [11-12]. Thus, the nano-architecture of the surface may be used to influence to some extent proteins behaviour upon adsorption. However, the investigation of topographical effects is somewhat sparse at present [11], and the reports available in literature have not been able to provide a clear and unambiguous understanding of the overall effect of surface nano-scale features on protein adsorption [7, 12, 15].

In different studies, FN adsorption has been suggested increase with the size of surface roughness [102-104]. The amount of adsorbed FN, either from plasma or isolated, increased on titanium surfaces with increasing mean surface roughness $(53,70$ and $183 \mathrm{~nm}$ ), even after correction for the increased surface area [102]. A linear correlation between nano-scale surface roughness and the amount of adsorbed FN was observed onto carbon nanotube/polycarbonate urethane composites with root mean square roughness values ranging from 2 to $20 \mathrm{~nm}$, however it was in part attribute to surface chemistry [103]. FN adsorption onto nanometer scale rough tantalum oxide surfaces (root mean square surface roughness $\sim 5 \mathrm{~nm}$ ) resulted in an increase of its surface mass density as compared to flat substrates, but this increase was found to be lower than the increase in surface area [104]; the authors ascribed this effect to a conformational change of the adsorbed proteins onto the nanorough surfaces, where FN would assume a more spread-out and rigid conformation.

In the case of $F G$, roughness on the nanometer scale has a significant impact on protein adsorption, with increased amount of adsorbed FG on nanostructures of higher roughness [105-106]. However, some studies, where the size of nano-topographic features was of similar order of magnitude, suggest have no significant effect on the amount of adsorbed FG [74, 102]. 
Nano-scale featured surfaces adsorbed significantly more serum proteins than microstructures surfaces [107]. Besides enhanced adsorption, differences in the selectivity of proteins adsorbed from serum were found as a result of nano-structuring: the nano-fibrous architecture of the pore walls of PLLA scaffolds altered the profile of protein adsorption with respect to solid-walled scaffolds, inducing selective enrichment in FN and VN [108]. Nano-phase ceramics affected the type and concentration of proteins adsorbed from serum as compared to conventional ceramics [109-110]; nano-phase alumina (grain size $24 \mathrm{~nm})$ and HAP $(67 \mathrm{~nm})$ adsorbed a significantly greater concentration of serum proteins with respect to conventional alumina $(167 \mathrm{~nm})$ and HAP (179 $\mathrm{nm}$ ). Moreover, the nano-phase ceramics were selectively enriched in VN (that may have preferentially adsorbed to the small pores present in these ceramics) and denatured collagen, while $\mathrm{LN}$ adsorbed in greater amounts onto conventional ceramics (characterized by larger pores) and $\mathrm{FN}$ adsorption was not affected by the change in surface topography.

Besides the amount of protein adsorption, topographical changes of nanometric order of magnitude can modify the conformation and therefore the activity of the adsorbed proteins. It seems that a surface roughness of the same order as the protein size does not promote conformational changes upon adsorption, while lower or higher values of roughness favor conformational alterations as proteins adjust to the nano-scale features of the surface $[7,11$, $15,110-111]$.

With regard to $\mathrm{FN}$, several studies proved that nano-topographical features are able to modulate its conformation upon adsorption [106, 112-113]. While the amount of FN adsorbed onto nano-rough colloidal silica surfaces was not altered with respect to flat control silica, the conformation of the protein was significantly affected by the change in nano-topography: RGD and the synergy sequences were hidden or sterically hindered on the nano-rough surfaces [106]. FN conformation by adsorbing the protein onto a nano-structured poly(lactic-coglycolic acid) (PLGA) surface with $500 \mathrm{~nm}, 200 \mathrm{~nm}$, or $100 \mathrm{~nm}$ spherical bumps 
[112]. AFM images revealed small globules of $F N$ on the surface with $500 \mathrm{~nm}$ features whereas bumps of lower sizes promoted the spreading of the FN molecules. The topographic features resulting from crystallization of PLLA were also shown to affect FN conformation: on rough semi-crystalline PLLA samples $\mathrm{FN}$ was not able to expand its dimer arms, hindering FN-FN interactions and therefore impeding the formation of an interconnected protein network, which was instead found on smooth amorphous substrates [113].

FG was also found to suffer changes in its conformation or orientation upon adsorption to topographically structured surfaces, adopting a favorable conformation as compared to flat control, whilst the amount of protein adsorption was not affected [114]. Collagen I morphology was also shown to be affected by nanometer-scale roughness [115-116]. Some studies suggest that a critical surface height variation, close to the thickness of the collagen molecule, might affect the mobility of the adsorbed proteins and their tendency to aggregate. Morphological differences in the collagen layer adsorbed were ascribed to changes in protein mobility. Collagen mobility was limited by nanostructured surfaces, impeding any form of supramolecular aggregation.

Topographical features have also been found to affect the distribution of the adsorbed proteins [117-120]. As a matter of fact, the mechanism of contact guidance has been interpreted in terms of protein adsorption: discontinuities or curvatures associated with topographic features such as grooves may trigger changes in protein adsorption, consequently affecting cellular response [117, 119-121]. FN and VN from serum had a tendency to adsorb with preference to the walls of the grooves of micro-patterned substrates [120]. In other system, higher amounts of protein adsorbed on the peaks with respect to the valleys of the topography [121].

In any case, the amount of the adsorbed proteins and their conformation, the morphology, composition, distribution and organization of the adsorbed protein layer can be modulated by changes in the nano-topography of the substrates; in 
this light, nanometer surface features may meet increasing success in controlling protein interactions for a number of tissue engineering applications.

\section{Surface Mechanical Properties}

While the effect of the mechanical properties of the substrate on cell response has been extensively investigated, very few reports address the effect of surface mechanical properties onto protein adsorption [122-123]. In fact, since proteins are not able to deform the substrate on which are adsorbed, it is expected that proteins remain unaffected by the mechanical properties of the surface. Sometimes changes in surface chemistry are also associated to the materials used to investigate the influence of mechanical properties [122-123]. An increase in Pellethane poly(ether urethane) weight percent of hard segment, surface hardness, and hydrophobicity resulted in an increase in total protein adsorption [123]. Later, increased FG adsorption onto a poly(carbonate urethane) surface was justified as a result of enhanced modulus or rigidity associated with the nano-phase separation [122].

\subsection{Cell adhesion}

The complex interactions of cells with the extracellular matrix (ECM) and with neighboring cells trigger numerous responses that have essential roles in the regulation of their behavior and fate [4, 124]. When biomaterials are employed as substrates for regeneration, many cellular events take place at the material interface, and cells try to mimic the natural adhesive interaction with the ECM [8, 17-18]. In fact, cells interact with foreign materials through the adsorbed protein layer. This interaction depends on the composition and structure of the protein layer, which therefore plays a critical role in determining subsequent cell behavior.

Cell attachment to ECMs is dynamic, spatially precise, and regulated bidirectionally between the cells and the matrix through integrins, which are the major class of adhesive receptors through which cell-matrix interactions occur. 
They can bind with a range of specificities to many different ligands in matrix proteins [17]. Integrins are a large family of $\alpha / \beta$ heterodimers that recognize specific sequences of ECM proteins, such as arginine-glycine-aspartic acid (RGD) tripeptide, and provide trans-membrane links between the ECM and the actin cytoskeleton [23]. Cells can express many different integrins at the same time, however, many integrins are not constitutively active; they often are expressed on cell surfaces in an "OFF" state, in which they do not bind ligands and do not signals. Integrin activation can occur either by ligand binding or by effects on the cytoplasmic domains, which led to conformational changes that expose epitopes for specific activation antibodies [23]. The relative number and activation state of integrins is highly dependent on cell type and physiological context, depending on disease state, developmental stage, or whether a healing process is ongoing. The most common integrins found in focal adhesions in vitro and other ECM adhesions are $\alpha_{5} \beta_{1}$ (the classical fibronectin receptor) and $\alpha_{v} \beta_{3}$ (vitronectin receptor).

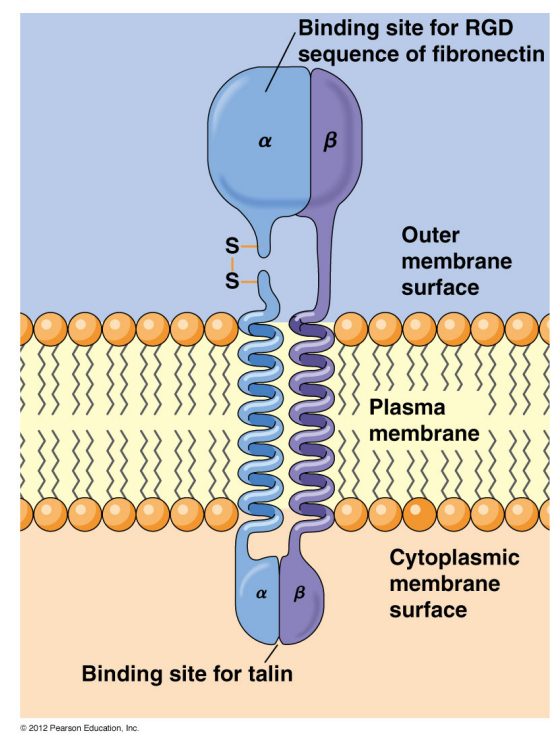

Figure 1.2 Integrin structure; transmembrane receptors which consist of two chains $(\alpha / \beta)$ with binding sites for ECM proteins and cytoplasmic tails for binding intracellular proteins. [Pearson education, Inc 2009] 
Beyond their role as mediators of cell attachment, integrins are at the same time signal transduction receptors, capable of initiating intracellular signaling events upon ligand binding, which can in turn influence growth, migration, proliferation or differentiation [125]. Substrate-bound integrins cluster and develop focal adhesions - discrete supramolecular complexes - that contain important structural proteins and signaling molecules that actually anchor the cells to the surface and trigger the subsequent cellular response [24]. After initial adhesion, cells spread on the substrate and acquire a flattened morphology, developing the actin cytoskeleton that provides mechanical stability and transmits forces to the cell interior [126-127].

Adhesions with the ECM act as binding bridges which link the ECM to the actin cytoskeleton at the cell interior. There are four varieties of well characterized adhesion structures: focal adhesions, fibrillar adhesions, focal complexes (dot contacts), and podosomes.

- Focal adhesions (also called focal contacts): flat and elongated structures that are several square microns in size and often located near the periphery of cells [128-131]. They are typically observed in vitro when cells are cultured on solid substrates. Focal adhesions mediate strong adhesion to the substrate, and they anchor bundles of actin microfilaments through a plaque that consists of many different proteins such as vinculin, talin, paxilin and tyrosine phosphorylated proteins. Development of focal adhesions is stimulated by the small GTPase Rho-A, and is driven by actomyosin contractility. It is believed that focal adhesions act as tactile mechanisms of cells, i.e., mechanosensors, permitting to sense not only chemical signals but also physical properties of the substrates and to convert them into specific biological signals [24, 132].

- Focal complexes: small, dot-like adhesions located mainly at the edge of lamellipodia. These sites can be associated with cell migration or serve as precursors of focal adhesions. They are also characteristic for cancer cells 
which do not have well developed adhesion structures. The Rho-family GTPase Rac participates in their formation [133-134].

- Fibrillar adhesions: elongated or dot-like structures that are associated with ECM fibrils and located in more central positions of many cell types [135137]. The typical components of fibrillar adhesions are the extracellular fibronectin fibrils, aligning with the fibronectin receptor $\alpha_{5} \beta_{1}$ integrin, and the cytoplasmic protein tensin [136].

- Podosomes: cylindrical structures containing some focal adhesion proteins (such as vinculin and paxillin). Podosomes are small actin-based adhesion structures.

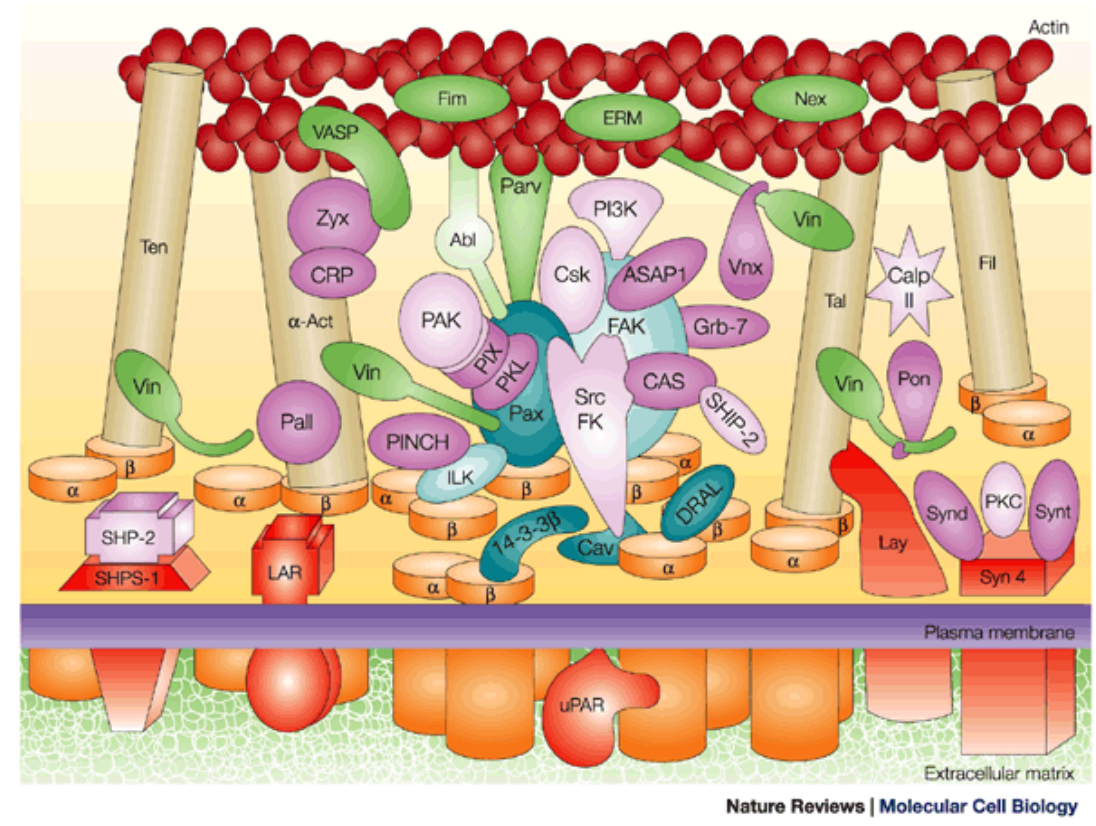

Figure 1.3 Schematic representation of focal adhesions. Primary adhesion receptors (integrins) represented by orange cylinders; membrane-associated molecules enriched in these adhesions (red); proteins interacting with both integrin and actin (golden rods); integrin-associated molecules (blue); actin-associated proteins (green); adaptor proteins (purple) [24]. 
In the cytoplasm, a small group of proteins (talin, a-actinin, tensin and filamin) can function as direct integrin-actin linkers [129, 138]. Vinculin acts as a universal linker because it interacts with many plaque proteins (including talin, $\alpha$-actinin etc), as well as with acidic phospholipids, membranes and actin. After integrin clustering, several signaling molecules such as focal adhesion kinase (FAK) and integrin-linked kinase (ILK) [139] are recruited to focal adhesions by adapter proteins such as paxillin, where they are activated.

Focal adhesion kinases (FAK) are non-receptor protein-tyrosine kinases that become activated in response to cell-ECM adhesion [140-141]. FAKs trigger the majority of signalling pathways [142-143]. FAK has emerged as an important mechanotransducer translating mechanical inputs coming from the extracellular matrix into biochemical signals in the cytoplasm. It is a key signaling protein contributing to integrin control of cell motility, invasion, survival, plays a fundamental role in determining cell cycle progression, proliferation and development [144-148]. It is needed as a regulator of focal adhesion assembly and turnover [145, 149] and promotes integrin activation to enhance the generation of cell-ECM adhesive forces [146]. Also, FAK is overexpressed in a variety of human cancers [142] and FAK signaling can promote invasive behavior of tumor cells $[143,150]$.

This kinase is activated by a mechanism involving FAT and FERM domain interactions with other integrin-associated proteins [151-153]. The activation state of FAK is defined mostly by the phosphorylation of tyrosine Y-397, an autophosphorylation site that lies in the linker region between the FERM and kinase domains. Y-397 phosphorylation creates a high-affinity binding site for the $\mathrm{Src} \mathrm{SH} 2$ domain, an interaction that recruits and activates $\mathrm{Src}$ in adhesions [154]. Formation of the complex with Src is the most critical event in FAKassociated signaling. Src bound to the Y-397 site phosphorylates other FAK residues [155-156], including Y-576 and Y- 577 in the kinase domain activation loop and Y-861, that are important for maximal FAK autophosphorylation activity [157]. 
FAK expression and phosphorylation of their tyrosine residues have shown to be affected by surface parameters of materials [158-166]. The possibility of controlling the adhesion of cells to their substrates represents a versatile mechanism to elicit specific cellular responses for biological and biotechnological applications.

\subsubsection{Role of surface properties on cell adhesion}

Even if the cell-material interaction is not a direct one, but it is mediated by ECM proteins adsorbed on the substrate; it is said that cells response to three different kinds of surface properties: chemical, topographical and mechanical [27].

\section{Hydrophilic/hydrophobic balance}

A classically parameter affecting protein adsorption and cell adhesion is the hydrophilic/hydrophobic balance. As explained before, hydrophobic surfaces tend to favor the adsorption of proteins, but irreversible adsorption and denaturation of the protein native conformation and bioactivity might occur. On the other hand, a highly hydrophilic surface may expel any protein molecule and inhibit protein adsorption. However, changes in surface wettability are often involved in modification of other material properties, thus contrasting results are found when the effect of wettability on cell behavior is investigated, which make it difficult to get clear conclusions. It is now well accepted in that both very hydrophilic and very hydrophobic surfaces are not good for cell attachment, rather, surfaces with moderate wettability are able to adsorb a proper amount of proteins, and at the same time preserve their natural conformation, resulting in adequate cell responses. Some recent works agree with this postulation, such as studies with the biodegradable polymers poly( $\varepsilon$-caprolactone) and poly(D,Llactide) [167]. By contrast, many other works have demonstrated that hydrophobic materials display good cell attachment [168]. 


\section{Surface chemistry}

Chemical modifications often produce changes in other physico-chemical parameter of the material, which also influence on cell response. Well-controlled systems, employed to study the influence of surface chemistry, are selfassembled monolayers (SAMs), which consist of surface coatings that form highly ordered structures on specific substrates. SAMs with different functional end groups have been used to study cell adhesion. The surface chemistry of these materials modulate focal adhesion composition and signaling of cells and hence can control the phenotype and function of a cell whereby the level of adhesion influences cell proliferation and differentiation and modulates other cell signaling pathways. Several works based on SAMs showed experimental data indicating that on polar and positively charged surfaces (endowed with $-\mathrm{OH}$ and $\mathrm{NH}_{2}$ groups) the spatial conformation of adsorbed fibronectin was more advantageous for binding osteoblast-like MC3T3-E1 cells through their $\alpha_{5} \beta_{1}$ integrin receptors than on non-polar and negatively charged surfaces $(-\mathrm{CH} 3$ and $-\mathrm{COOH}$ groups) [40, 162]. Indeed, SAMs with hydrophilic properties differentially modulate promotion to cell differentiation in myoblast cells [169] and osteoblast cells [170]. It is also described that SAMs with different surface chemistry differentially modulates human mesenchymal stem cells differentiation in a lineage dependent manner [171].

\section{Surface topography}

Depending on the scale of irregularities of the material surface, macroroughness (100 $\mu \mathrm{m}$ - millimeters), micro-roughness (100 nm - $100 \mu \mathrm{m})$, and nano-roughness (less than $100 \mathrm{~nm}$ ) can be distinguished. Macro-roughness seems to enhance tissue integration, since it facilitates the anchorage of implants into the natural tissue even if is thought not to be felt by the cells, e.g., it does not restrict their attachment and spreading. The effect of micro-scale roughness is more controversial, because the cells can be limited by the material surface topography in their adhesion area [172-173]. By contrast, the 
presence of nano-scale features increases cell attachment, proliferation and cytoskeletal assembly.

The influence of micro-scale features on the cytoskeletal filaments is easier to appreciate due to the scale of the features is of the same order of magnitude compared with the cell. However, nano-scale features are far smaller than the cell, corresponding in size to features such as filopodia and microspikes (effectively the "sensing" organelles of the cell), which may heighten the cell level of perception; it seems therefore likely that nano-topography will change the cell behavior through modifications in adhesion formation rather than though mechanical constraints.

Several authors have reported that osteoblasts, grown on micro-rough surfaces, were stimulated towards differentiation as shown by their gene expression and higher level of mineralization in comparison with cells growing on smooth surfaces [173-174]. Besides, the nano-scale structure of the material surface has been found to have significant positive effects on osteoblast cell response, including initial cell adhesion and subsequent proliferation, and expression of differentiation markers. This finding is not so surprising when we keep in mind that the natural environment of cells, the extracellular matrix (ECM), is also organized at the nano-scale level.

It must be considered that not only the scale of surface topography affects cell behavior, but also the feature type - for example ridges, pits, or grooves, and their random or even distribution - has a consequence on cell fate. At present, there is great disparity between the experimental approaches of different research groups, making it difficult to compare data on similar systems. A common theme of cellular adhesion on nano-scale protrusions is the observation of a decrease in cellular adhesion with increasing nano-protrusion height (> 70nm) [175]. Reducing the height of the nano-protrusion features to less than $50 \mathrm{~nm}$ has been shown for numerous cell types to return the frequency of focal adhesion formation to that of cells cultured on planar 
controls, with accompanying upregulation in proteins critical to cytoskeletal dynamics [176].

As with nano-scale protrusions, pitted-like topographies have been shown to produce different effects on cellular behavior, depending on pit diameter, spacing and symmetry of pit positioning [177-178]. It seems that the spacing and density of the nano-pit features are as influential on focal adhesion formation as the feature size, at the nano-scale level. Some studies indicate that introducing a degree of disorder or increasing the inter-pit area enhances focal adhesion formation and subsequent cellular spreading as well as cellular function [179].

Micro-groove/ridge surfaces have shown significant control over cellular behaviors. The most important phenomenon is that the cell spreading, alignment, and migration can be oriented along the grooves/ridges. One already classical theory that accounts for this phenomenon is called "contact guide effect", in which the cell integrin receptors in the focal contact transfer the variable degrees of tension or compression into the cytoskeleton, and cell stretch receptors subject to these stresses are activated and reorganize the cytoskeleton according to the surface topography [180]. In addition to grooves and ridges, micro-pillars enhance cells spreading, adhesion [181] and migration [182].

Nano-grooved topographies may also produce very predictable effects on cellular morphology. Indeed, the elongated morphology and alignment induced by grooved substrates may resemble the natural state of many cell populations in vivo and is observed to occur in a wide range of cell types, including fibroblasts [183], osteoblasts [184], nerve cells [185] and MSCs [186], which respond profoundly to grooved substrates. However, at present no clear conclusions have been reached about the absolute size required for cellular and focal adhesion alignment. 
Some studies suggest that contact guidance is not initiated on groove depths below $35 \mathrm{~nm}$ [187] or ridge widths < $100 \mathrm{~nm}$ [188]. Similarly, contact guidance or a modulation in focal adhesion formation is not initiated on anisotropic grooved topographies with feature widths significantly greater than that of the cellular diameter. It can be argued that such topographies are essentially planar areas separated by a topographical step that neither perturbs integrin activation and clustering nor offers an increased surface area to facilitate focal adhesion formation [189].

To summarize, nano-structures have been shown to induce significant modulation of focal adhesion formation, cytoskeletal development, and cellular spreading, changes that are subsequently transduced to signaling pathways, affecting functional differentiation.

\section{Mechanical properties}

There is substantial evidence that substrate rigidity is a key element to determine cell response [190-194]. Mechanical properties of the substrate play an important role in cell response regardless of surface chemistry and topography; nevertheless, this phenomenon has not been completely understood yet. It is known that cell spreading and motility are higher on stiff substrates than on soft ones, which favors cell-cell interaction and leads to more organized cell aggregates [195]. Well-developed focal adhesions connected by actin fibers are found in cells cultured on rigid/stiff substrates; however, these structures are gradually lost as cells are grown on softer matrices [196-198]. Cell proliferation increases on stiff surfaces and, in the case of a rigidity gradient on the substrate, cells migrate to stiffer regions (durotaxis) [190]. This kind of cell behavior has been found for different cells types (fibroblasts, muscular VSMC cells, chondrocytes and neurons), independently of the protein coating of the substrate (fibronectin, collagen, etc).

Seminal work from Engler et al. provided the first evidence that matrix elasticity can direct stem cell lineage specification in the absence of soluble 
induction factors [199]. MSCs on the stiffest substrates expressed early markers of osteogenesis, whereas these cells on intermediate stiffness gels expressed myogenic markers and cells on the softest gels expressed neuronal markers.

It is thought that cells are able to react to substrate rigidity by means of a real tactile exploration, by exerting contractile forces and interpreting the substrate deformation [200-202]. However, it would appear that substrates of very high stiffness cannot be deformed by cells, thus must be sensed as simply rigid substrates by cells [203-204]. Moreover, it has been shown that cells are able to sense the stiffness up to $1 \mu \mathrm{m}$ depth [205-206], which has to be taking into account when the effect of stiffness on cell response is investigated.

The preparation of substrates with controlled rigidity often leads to small variations in substrate chemistry, as observed in changing the crosslinking ratio in a polyacrylamide gel [198-199], thus some controversial results have been obtained in terms of surfaces stiffness. Cultures of MC3T3-E1 cells on polyacrylamide substrates with different mechanical properties showed that rigid substrates enhance cell proliferation and osteogenic differentiation [158]. Otherwise, when cells were cultured on alginate gels, they were found to differentiate better on the softer substrates [207]. The observed opposite results - with the same cell line and substrates of similar stiffness - could be partly a consequence of changes in surface chemistry.

Some other studies report that the effect of varied substrate stiffness on cell behavior is only manifest in combination with topography. Surface patterns with $10 \mu \mathrm{m}$ wide grooves induced significant cell adhesion and spreading on PEGbased hydrogels. In contrast, only little adhesion was detected on smaller and larger pattern sizes and no adhesion at all on the smooth substrates, regardless of the rigidity of the gel [208]. 


\subsection{Remodeling of adsorbed proteins}

\subsubsection{Reorganization and secretion at the cell-material interface}

Cellular interaction with ECM is highly dynamic in nature. In particular, cells are not only receiving information from specific cues in the ECM [209], but, simultaneously, and as consequence, cells respond to these inputs by remodeling the surrounding matrix and/or secreting new one $[17,23,210]$.

Not only the physico-chemical properties of the surrounding ECM influence on its reorganization, but also its mechanical properties are important. For instance, when the stiffness of the surrounding ECM is in the same order of magnitude as the cells, they are able to reorganize this matrix [211-212]. However, on stiffer materials cells may fail to do so, and this is an obstacle for the biocompatibility of the material.

Cells tend to rearrange matrix proteins adsorbed on material surfaces in a fibril-like pattern, seeking to mimic the ECM organization in vivo [213-214]. It seems that biocompatibility of the materials may be connected with the allowance of cells to remodel surface associated proteins, presumably as an attempt to form their own matrix. Several cell types (including fibroblasts and endothelial cells) tend to rearrange adsorbed matrix proteins, such as FN, FG and collagen [213-215], in a fibril-like pattern. Moreover, this cellular activity depends on the surface properties of materials, such as wettability [216], surface chemistry and charge $[43,217]$.

FN reorganization at the cell-material interface was initially thought to occur on hydrophilic substrata without rearrangement on hydrophobic ones (SAMs). However, since cells need to modify adsorbed FN for their normal function, it is suggested that surfaces that adsorb proteins loosely will result in better substrates for cell growth. Cells remove and organize FN from the substrate into specific fibrillar structures, similar to FN matrix fibrils that occur during the physiological fibronectin fibrillogenesis [214, 216]. The arrangement of natural 
FN matrix is also dependent on the ability of cells to reorganize the adsorbed FN layer on the material substrate. FN matrix secretion was higher on hydrophilic glass compared to the hydrophobic one; despite cell spreading was similar [218].

However, recent investigations have shown that even if cells need the adequate environment to synthesize their own matrix at the cell-material interface, this does not exclusively occur on hydrophilic materials. The system based on the copolymerization of ethyl acrylate and hydroxyethyl acrylate is an example of how things can happen in a different way: cells are able to synthesize and deposit FN matrix fibrils on some of the material surfaces. FN fibrils could not be found on the more hydrophilic samples, while on the sample with intermediate composition the fibroblasts deposited only small fibrils, located mostly beneath the cells. As the hydroxyl fraction decreases (and the surface becomes more hydrophobic), the FN deposition increases, and, moreover, it is organized into a typical matrix-like structure similar to those on the hydrophilic glass [216]. No reorganization of FN takes place whatever the hydroxyl fraction of groups in the sample, thus does not depend on the hydrophilicity for this family of substrates. It is noteworthy, however, that the values for the wettability of the PHEA samples (water contact angle, WCA, of $\sim 45^{\circ}$ ) correspond to values that are optimal for the cellular interaction in other systems. Conversely, surfaces with about $90^{\circ}$ WCA, characteristic for pure PEA, and where the best cellular interaction was found, usually abrogate cellular interaction [19, 42, 219]. Collectively, this suggests that, even if unable to organize the pre-adsorbed FN on the substrate, the fibroblasts respond to the FN network previously formed during protein adsorption on the substrate, presumably because the conformation of the protein provides the adequate signals which stimulate their normal matrix-forming activity [220].

These results suggest that the distinction between hydrophilic and hydrophobic features of a substrate is not the adequate one to explain the general trends underlying the cell-material interaction, and more factors must be 
taken into account, such as the particular substrate chemistry that triggers the process of protein adsorption. Both protein conformation on the substrate and the intensity of the protein-material interaction play a fundamental role on cell behavior: the adequate protein conformation on the substrate results in excellent cell adhesion and matrix formation (for low -OH contents), even if preadsorbed FN cannot be removed by cells. Alternatively, if protein conformation is good enough so as to support initial cell adhesion, cells will be able to remove the initial FN layer and secrete their own extracellular matrix (as it happens in the control glass). Higher $-\mathrm{OH}$ fractions in the substrate often lead to inadequate protein conformation on the substrate, which does not support cell adhesion and consequently leads to diminished functionality.

However, relatively little is known about the fate of these already arranged matrix proteins. Recent data indicate that polymerized forms of the matrix proteins have properties distinct from protomeric, non-polymerized ones [36, 221-222]. Integrin-mediated assembly of FN into fibrils is well documented [223225]. In addition, FN may tether other matrix proteins to the cell surface, and therefore is required for their organization [213, 226]. It provides also new insights on the mechanisms for other fibrillar matrix proteins assembly, such as collagen and thrombospondin [223] or FG [215, 227-228].

\subsubsection{Proteolytic remodeling at the cell-material interface}

ECM remodeling is a dynamic process that consists of two opposite events: assembly and degradation. Proteolytic degradation of ECM is a mechanism for the removal of the excess ECM usually approximated with remodeling. These processes are mostly active during development and wound healing and regeneration of tissues but, when misregulated, can contribute to diseases such as fibrosis, arthritis, reduced angiogenesis, and developmental abnormalities [221-222, 229-230]. The invasive behavior of cancer cells is also due to upregulation of matrix remodeling [231-232]. 
Matrix remodeling is subject of extensive biomedical research, but how it relates to the biocompatibility of materials remains unclear. Upon implantation, foreign materials often trigger an uncontrolled deposition of fibrous matrix that, difficult to be predicted, hampers the biocompatibility of the implant. ECM organization in vivo is regulated by the $3 \mathrm{D}$ environment and the cellular tension that is transmitted through integrins [23]. It is difficult, however, to create such an environment on the biomaterials surface. Thus, identifying factors that control matrix deposition on the materials interface is an essential step for understanding the mechanisms involved in the pathological host response.

The proteolytic cleavage of ECM components represents a main mechanism for ECM degradation and removal [233-234]. Several families of proteases operate at the ECM level, including matrix metalloproteinases (MMPs), cysteine proteases and serine proteases. Proteolysis may also regulate the ECM assembly, editing the excess ECM components. During enzymatic remodeling of ECM structures, bioactive fragments and growth factors can be released that will affect cell growth, morphogenesis, tissue repair, and also various pathological processes.

The major enzymes that degrade ECM and cell surface associated proteins are MMPs, a family of secreted and membrane bound proteinases. Recently, the role of MMPs in both development and diseases has been extensively studied and reviewed because it is tightly linked with the mechanisms of tumor invasion and metastasis [235]. MMPs are a family (24 members) of zinc dependent endopeptidases, which together with adamalysin-related membrane proteinases that contain disintegrin and metalloproteinase domains (ADAMs or MDCs), such as thrombin, tissue plasminogen activator (tPA), urokinase (UPA) and plasmin, are involved in the degradation of ECM proteins. MMPs are either secreted or anchored to the cell membrane by a transmembrane domain or by their ability to bind directly uPAR and integrin $\alpha_{v} \beta_{3}[236]$. 
Activation of proMMPs requires physical delocalization of the prodomain from the catalytic site. Most of the MMPs are secreted as proenzymes and their activation occurs in the pericellular and extracellular space. By contrast, all transmembrane-MMPs and some of the secreted MMPs can be activated intracellularly by furins [237].

ECM remodeling is poorly understood at the biomaterials level. While mechanical strain is known to be able to enhance MMP expression [238], only a few examples in the literature have related the use of synthetic materials to the transcription and activity of MMPs [235, 239-241].

\subsection{Fibronectin fibrillogenesis}

\subsubsection{Fibronectin structure}

Fibronectin is a high molecular weight glycoprotein of the ECM. It is a single gene-encoded protein. Its $8 \mathrm{~kb}$ mRNA can be alternatively spliced allowing the expression of larger variety of $\mathrm{FN}$ isoforms [242]. The two major different forms of $\mathrm{FN}$ are plasma ( $\mathrm{pFN}$ ) and cellular $\mathrm{FN}(\mathrm{cFN})$. $\mathrm{pFN}$ is produced by hepatocytes and secreted into the blood, where it remains in a soluble form in order to avoid fibrillar formation that may cause severe diseases. Additionally, in blood, haematopoietic cells are adapted to express their integrins in an inactive conformation; hence, both mechanisms prevent the binding of pFN to cells. pFN plays an important role in wound healing. In case of a vascular injury or wound, integrins shift to their active conformation by a platelet-mediated mechanism, and $\mathrm{pFN}$ can bind and assemble into fibrils that are required for thrombus growth and stability [243-244]. On the other hand, cFN is found as an insoluble form in connective tissues and attached to cell surfaces. cFN is secreted by cells as a dimer in a compact globular structure and then is assembled into fibrils (insoluble form) in a cell-dependent process. 
FN contains domains to interact with other ECM proteins, glycosaminoglicans (GAGs), cell surface receptors (integrins), other FN molecules and also pathogens such as bacteria [245]. This combination of domains allows the simultaneous binding of $\mathrm{FN}$ to cells and other molecules. Each dimeric subunit of the FN molecule ranges in size from 230 to $270 \mathrm{kDa}$, depending on alternative splicing of the mRNA, and binds into dimers via two disulfide bonds at the C-terminus of the protein. Each subunit FN contains three types of repeating modules, types I, II and III (Figure 1.4). The type I and II units contain two intramolecular disulfide bonds to stabilize the folded structure, while type III units lack this kind of bridges. Both type I and II protein modules are structured in $\beta$-sheets enclosing a hydrophobic core containing highly conserved aromatic amino acids [245-246]. The repeat III 9 contains the Arg-GlyAsp (RGD) sequence recognized by several cell surface receptors, including the $\alpha_{5} \beta_{1}$ integrin.

Extra type III repeats (A and $B$ ) are produced by alternative splicing and included in cFN molecules, but they are not present in pFN; it seems that the alternative exons are not necessary for matrix assembly, but lacking them may affect matrix levels [245-246]. A variable region $V$ is present in the vast majority of cFN subunits, but only in one subunit of the pFN dimer. Results concerning this region suggest that it is essential for FN dimer secretion [247] and provides the binding site for $\alpha_{4} \beta_{1}$ integrin [248]. 


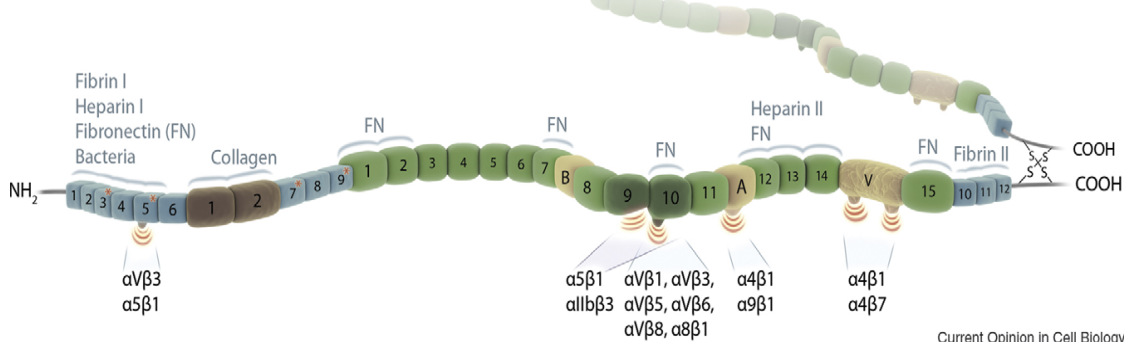

Figure 1.4 Molecular structure of FN that consists of three different modules (type I, blue; type II, brown; type III, green). The alternatively spliced extradomains B, A and variable region $(\mathrm{V})$ are colored in ochre. The FN dimer forms via two disulfide bonds at the $\mathrm{C}$ terminus. Integrin binding sites are indicated, as well as other binding domains for $\mathrm{FN}$, collagen, fibrin, heparin and bacteria [249].

\subsubsection{Cell-driven fibronectin fibrillogenesis}

\section{Essential domains for FN assembly}

FN matrix assembly is a cell-dependent process mediated by the binding of FN dimers to integrin receptors, which link the FN to the actin cytoskeleton and other cytoskeletal-associated proteins. The essential domains for FN assembly include:

- $\quad$ FN dimerization, which depends on covalent association of the subunits mediated by a pair of disulfide bonds at the C-terminus of the FN molecule.

- The 70-kDa fragment, which extends from type $I_{1}$ to $I_{9}$, including the $\mathrm{N}$ terminal assembly domain, composed by the first five repeats of type I units, and the collagen/gelatin binding domains. Within the $70-\mathrm{kDa}$ fragment, it seems that the binding activity resides only in the type $\mathrm{I}_{1-5}$ portion of the molecule (the $\mathrm{N}$-terminal assembly domain), which is the nexus point that binds $\mathrm{FN}$ molecules to each other by noncovalent interactions [250]. Therefore, FN fibrils formation and consequently FN matrix assembly depends directly on this domain. 
- The Arg-Gly-Asp (RGD) sequence located in repeat $\mathrm{III}_{10}$ and the synergy sequence PHSRN located in repeat $\mathrm{II}_{9}$, whose binding to $\alpha_{5} \beta_{1}$ integrin is required for the cell-mediated $\mathrm{FN}$ assembly to occur [251]. Blocking antibodies directed against either the cell binding domain of $F N$ or $\alpha_{5} \beta_{1}$ receptor inhibit fibril formation [252-253]. Although both sites are required for fibril formation, the synergy site is not essential because matrix levels are drastically reduced but not ablated with $\mathrm{FN}$ lacking this sequence [254].

However, not only $\alpha_{5} \beta_{1}$ integrin binds to RGD, but also several additional integrins, including all members of the $\alpha_{v}$ subfamily, $\alpha_{8} \beta_{1}, \alpha_{9} \beta_{1}$ and the plateletspecific $\alpha_{1 \mathrm{lb}} \beta_{3}$. Interestingly, in absence of $\alpha_{5} \beta_{1}$ integrin expression in cells, $F N$ can still be assembled by the operation of other integrins, most notably the $\alpha_{v}$ integrin subfamily [255-256]. In fact, the double knockout of $\alpha_{v}$ and $\alpha_{5}$ integrin genes lacks the capacity of FN fibril formation [257]. However, the $\alpha_{v}$-class produced fibrils are shorter and thicker than the $\alpha_{5}$ produced [258]. The possible role of the co-existence of both types of fibrils is still an unanswered question: maybe diverse types of FN fibrils could provide tissues with $\mathrm{FN}$ matrices with different qualities, implicating different functional properties [258].

On the other hand, the Asn-Gly-Arg (NGR) sequence located at the first five repeats of type I module is a high affinity binding site for $\alpha_{v} \beta_{3}$ integrin [259]. Therefore, the initial binding of $\alpha_{5} \beta_{1}$ integrin to the RGD sequence is not the only way to promote fibrillogenesis [258].

Other FN binding domains are implicated in matrix assembly: III ${ }_{1-2}$ and $\mathrm{III}_{12-14}$ can bind $\mathrm{FN}$; in addition, $\mathrm{II}_{1}$ can bind to $\mathrm{III}_{7}$, and $\mathrm{II}_{2-3}$ can interact with $\mathrm{III}_{12-14}$ [245]. All these domains can promote FN fibrillogenesis due to the ability to bind $\mathrm{FN}$, but they can also participate in intramolecular interactions that keep soluble FN in a compact form [260].

FN has two heparin binding domains on $\mathrm{I}_{1-5}$ and $\mathrm{III}_{13-15}$ and both participate in the binding of proteoglycan cell surface receptors. This binding promotes FNfibrillogenesis via at least two mechanisms. Firstly, they can activate protein 
kinases such as FAK that promotes integrin clustering and focal adhesion assembly. Secondly, they activate small GTPases such as RhoA and Rac1 via a $\alpha_{5} \beta_{1}$ bonded integrins-mediated process. The activation of such GTPases is required to generate the necessary force to unfold $\mathrm{FN}$ molecules for matrix formation [258].

\section{FN fibrillogenesis and regulation of matrix assembly}

$\mathrm{FN}$ in solution has a compact conformation and does not form fibrils even at extremely high concentrations. This compact form is maintained by intramolecular interactions between $\mathrm{II}_{2-3}$ and $\mathrm{III}_{12-14}$ modules [260]. Soluble FN can bind selectively to cell surface receptors, integrins such as $\alpha_{5} \beta_{1}$, which is the primary integrin for FN matrix assembly via binding to the RGD and synergy sites. FN-integrin binding induces integrin clustering, which groups together cytoplasmic molecules such as FAK, Src Kinase, paxillin and others, promoting the formation of focal complexes. These complexes activate the polymerization of the actin cytoskeleton and kinase cascades-mediated intracellular signaling pathways [24]. Receptor clustering by dimeric FN helps to organize FN into short fibrils. After that, the contractility of the cytoskeleton contributes to FN fibril formation [261-262]. The process is controlled by Rho GTPases that stimulate Rho kinases to enhance cell contractility by inducing actin-myosin interactions and actin rearrangement into stress fibers [261]. Rho activation also stimulates FN incorporation into a matrix [262]. The stretching due to cell contractility provokes a progressive extension of the $\mathrm{FN}$ molecule and the exposition of binding sites that mediate lateral interactions between $\mathrm{FN}$ molecules. 

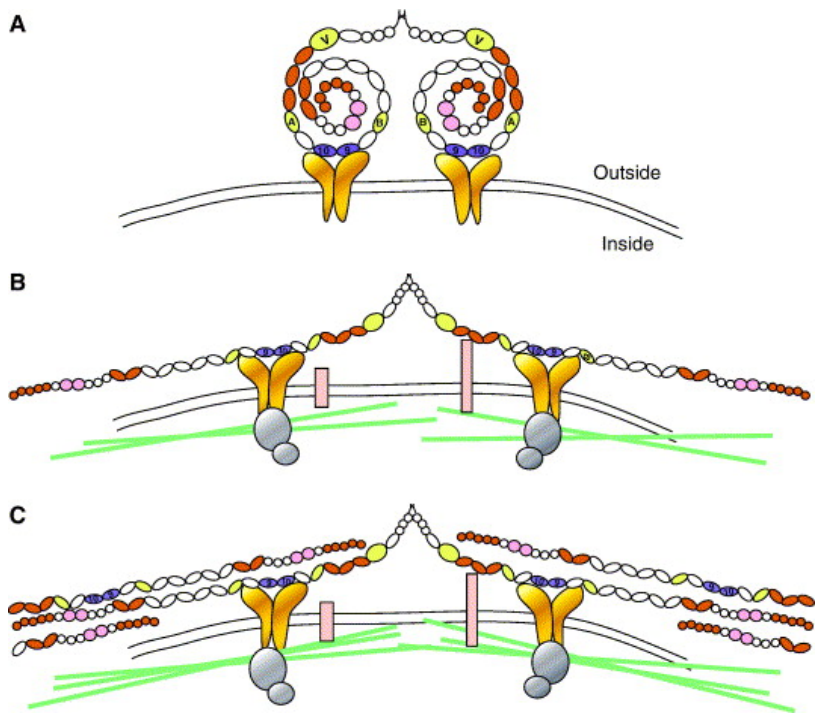

Figure 1.5 Major steps in FN fibril assembly. (A) Compact soluble FN binds to integrin $\alpha_{5} \beta_{1}$ (gold) via its cell binding domain. (B) FN binding to integrins and other receptors (pink bars) induces reorganization of the actin cytoskeleton (green lines) and activates intracellular signaling complexes (silver circles). Cell contractility aids in FN conformational changes thus exposing sequestered $\mathrm{FN}$ binding domains in the extended molecule. (C) Fibrils form through FN - FN interactions [245].

Initial thin fibrils then grow in length and thickness as the matrix matures and FN fibrils are converted in an insoluble form [246]. There is also continuous FN polymerization needed for matrix stabilization, a phenomenon that shows a tight relationship between FN polymerization and turn-over, mediated by endocytosis of soluble FN [263]. Thus, the dynamic interactions between FN, integrins and intracellular proteins are essential for FN matrix assembly and regulation.

In fact, certain pathways are critical for the initiation and maintenance of the matrix assembly. FAK plays a central role in integrin signaling and loss of talin binding to $\beta_{1}$ integrin reduces FN assembly [264]. Other focal adhesion proteins participate in the assembly but they are not essential, such as the Src kinase family, which, among other functions, phosphorylates paxilin. Inhibition of Src kinase caused a loss of matrix due to reduction in paxilin phosphorylation levels 
[265]. As mentioned above, a continuous FN polymerization for matrix maintenance is needed. The same mechanism would act with focal adhesion proteins involved in matrix assembly. They are needed not only in the initial steps of assembly; they also participate to maintain matrix association with the cell surface.

Proper integration of extracellular signals with active intracellular pathways plays a crucial role in the initiation, progression and regulation of $\mathrm{FN}$ matrix assembly [266].

\subsubsection{Cell-free assembly of fibronectin fibrils}

The need for controllable and reproducible in vitro models of fibronectin (FN) fibrils and for new synthetic materials able to serve as bio-inspired scaffolds for tissue engineering has driven the efforts in biology and regenerative medicine for the identification of cell-free routes able to induce $\mathrm{FN}$ fibrillogenesis. These routes are based on the assumption that unfolding of soluble $\mathrm{FN}$ dimers from their globular conformation exposes cryptic domains needed for FN-FN interactions to occur, leading eventually to FN polymerization and fibril formation. The methods that have been used in literature include: addition of reducing [267-268] or oxidizing [269] agents to the protein solution; use of denaturing [270-272], cationic [273-274] or anionic [275-276] compounds; and the use of peptidic FN fragments [277-278]; which allow the formation of FN multimers. Force-based assembly, via application of mechanical tension [279282] or shear forces [283-288], which allow the unfolding of FN dimers; and surface-initiated assembly, where the unfolding of soluble FN is obtained as a result of its adsorption onto a material surface [220, 289-293].

\subsubsection{Material-driven fibronectin fibrillogenesis}

Significant efforts in regenerative medicine research have been focused on engineering materials that recapitulate characteristics of the ECM, such as the 
presentation of cell-adhesive motifs or protease-degradable cross-links, in order to direct cellular responses [294-295]. However, material-based approaches to reconstitute the network structure and bioactivity of $\mathrm{FN}$ fibrillar matrices have not been established yet. Different studies indicate that changes in the structure of $\mathrm{FN}$ are required to expose sites within the molecule to drive its assembly into fibers [272, 278, 280-281]. In our group, it has been hypothesized that adsorption of individual FN molecules onto particular surface chemistries would induce exposure of self-assembly sites to drive FN fibril assembly and identified poly(ethyl acrylate) (PEA) as a potential surface chemistry to generate FN fibrils $[65,118]$. The organization of $F N$ molecules at the material (PEA) interface has been investigated [65].

\section{Physiological organization of fibronectin at the material interface}

The development of a FN network in the absence of cells gains a distinct bioengineering interest because it is a way to improve the biocompatibility of materials. It is well documented that cells recognize faster and with higher affinity already assembled FN fibrils versus adsorbed protein [296-297].

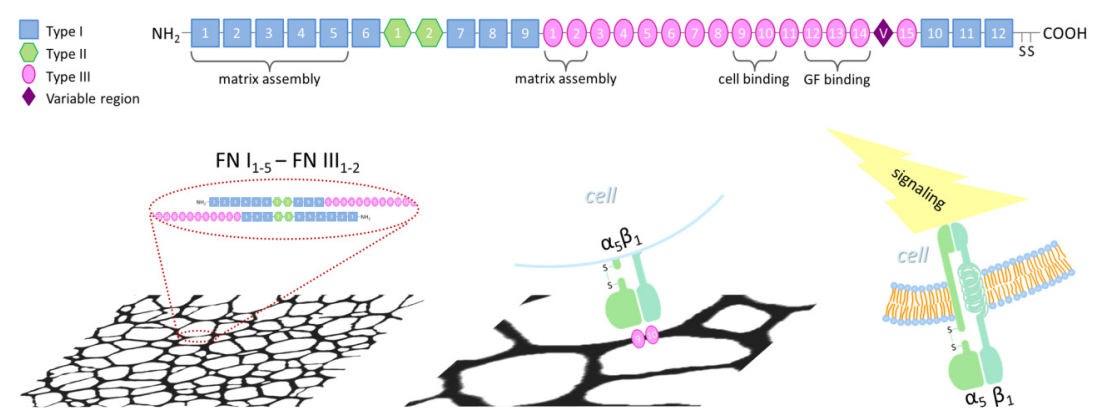

Figure 1.6 Molecular structure of a monomer of $\mathrm{FN}$ with indication of the main domains involved in matrix assembly, cell binding, or growth factor binding. The material-driven fibrillogenesis leads to the formation of a biologically active network through interactions between $\mathrm{I}_{1-5}$ and $\mathrm{III}_{1-2}$ domains. 
Interconnected FN fibrils are organized upon adsorption from a solution of concentration $20 \mu \mathrm{g} / \mathrm{ml}$ on PEA. FN fibril formation on PEA is dependent on the FN solution concentration, as lower concentrations result in dispersed adsorbed molecules [220]. The role of the $70 \mathrm{kDa}$ amino-terminal domain of $\mathrm{FN}$ in this material-driven fibrillogenesis process was examined. The $70 \mathrm{kDa}$ aminoterminal regions are known to be essential for cell-mediated FN assembly, and within this region, the $\mathrm{I}_{1-5}$ repeats confer $\mathrm{FN}$ binding activity [298]. This domain is not accessible in the folded, compact structure of $\mathrm{FN}$ in solution and a conformational change of the molecule is mandatory for physiological matrix assembly to occur [297]. Strikingly, material-driven fibrillogenesis absolutely requires the $70 \mathrm{kDa}$ amino-terminal region of $\mathrm{FN}$. Addition of the $70 \mathrm{kDa}$ fragment completely blocks the organization of $\mathrm{FN}$ at the material interface and only discrete molecular aggregates can be observed, without any trace of the assembled FN network. These results demonstrate that particular polymer chemistry (PEA) drives assembly of adsorbed FN molecules into FN fibrils and this material-driven fibrillogenesis requires the $70 \mathrm{kDa}$ amino-terminal domain of FN.

The dynamics of the formation of the FN network on PEA was followed via AFM at different adsorption times [91]. At the very beginning of the adsorption process (10 s), isolated FN molecules are homogeneously distributed on the material. After $30 \mathrm{~s}$ of adsorption, the molecules tend to align suggesting the initial formation of intermolecular connections, which result in protein-protein contacts through the surface. After $60 \mathrm{~s}$, AFM images reveal the formation of a protein network on the material surface. Increasing the adsorption time results in thickening the fibrils, which make up the protein network [91]. These results allow one to conclude that FN organization on the material interface occurs in a timescale that is adequate to be followed via AFM, whose acquisition time is in the minute range.

Seeking to follow the adsorption process in a more detailed way, the adsorption time was fixed and solutions of increasing concentration of FN were 
employed [118]. FN adsorbed onto PEA substrates after immersion for $10 \mathrm{~min}$ in protein solutions of different concentrations: $2,2.5,3.3,5,20$, and $50 \mu \mathrm{g} / \mathrm{mL}$ was analyzed by AFM. The lowest concentration results in isolated extended FN molecules homogeneously distributed on the material. For a concentration of $2.5 \mu \mathrm{g} / \mathrm{mL}$, a higher density of $\mathrm{FN}$ molecules is observed; extended FN molecules tend to align, suggesting the initial formation of intermolecular connections. FN conformation suggests the incipient formation of a protein network on the material when $F N$ is adsorbed from a solution with a concentration of $3.3 \mu \mathrm{g} / \mathrm{mL}$. Protein adsorption from higher solution concentrations gives rise to the formation of $F N$ networks on the material with higher cross-link density, i.e., a higher number of cross-link points and lower distance between them [118].

The formation of FN networks on PEA must be a consequence of the following sequence of events:

(1) Conformational change upon FN adsorption on PEA. It is known that FN has a compact folded structure in physiological buffer that is stabilized through ionic interactions between its arms [260]. FN interaction with chemical groups of the substrate (a vinyl backbone with $-\mathrm{COOCH}_{2} \mathrm{CH}_{3}$ side chain) gives rise to conformational changes in the molecule that lead to the extension of the protein arms. Adsorption of FN onto slightly charged surfaces (negative neat group in the $-\mathrm{COO}^{-}$group) gives rise to elongated structures of the molecule, as obtained for $\mathrm{SiO}_{2}$ and glass $[86,88]$. It is likely that $\mathrm{FN}$ orients at the surface, so that its hydrophobic segments interact with the methyl groups in PEA, maybe throughout the heparin-binding fragment, as proposed for the FN-DPPC interaction [281], but with more efficient arm extension results because of the neat negative charge of the surface.

(2) Enhanced FN-FN interaction on the PEA substrate. The adequate conformation of individual FN molecules as the adsorption process continues favors FN-FN interactions involving the amino-terminal $70 \mathrm{kDa}$ fragment [86], 
probably throughout the interaction between $\mathrm{I}_{1-5}$ and $\mathrm{III}_{1-2}$ domains located near their amino side [8].

(3) Formation of the FN network. New FN molecules are preferentially adsorbed in close contact to $\mathrm{FN}$ molecules already present on the substrate, probably as a consequence of the presence of polar-oriented FN molecules enhancing the collision rate of FN self-assembly sites [242], which finally gives rise to the initial formation of a protein network on the substrate. This process leads to a well-interconnected network of FN on the surface of the substrate [118]. Adsorption from solutions of higher concentrations leads to the formation of a protein network with thicker arms.

The formation of a FN network on PEA is not a universal property of this protein. For example, a similar network was found for fibrinogen [72] and collagen IV [76], but only globular-isolated molecules were observed after laminin [98] and vitronectin adsorption [75].

Given its similarities with the physiological assembly of $\mathrm{FN}$, the materialdriven FN fibrillogenesis is expected to yield a protein network with enhanced biological activity [65]; since the conformation adopted by the protein might promote the exposition of domains that favor the interaction with cells and other proteins. 


\subsection{References}

1. J.P. Vacanti, C.A. Vacanti. The history and scope of tissue engineering. in Principles of tissue engineering, R.L. Lanza, R. Langer, J. Vacanti, Editor. 1997.

2. D.F. Willams. On the mechanisms of biocompatibility. Biomaterials, 2008. 29, 29412953.

3. L.S. Nair, C.T. Laurencin. Biodegradable polymers as biomaterials. Progress in Polymer Science, 2007. 32, 762-798.

4. B.M. Gumbiner. Cell adhesion: the molecular basis of tissue architecture and morphogenesis. Cell, 1996. 84, 345-357.

5. C. Werner, T. Pompe, P. Katrin. Modulating Extracellular Matrix at Interfaces of Polymeric Materials. Advances in Polymer Science, 2006. 203, 63-93.

6. T. Tsapikouni, Y. Missirlis. Protein-material interactions: From micro-to-nano scale. Materials Science and Engineering: B, 2008. 152, 2-7.

7. W. Song, H. Chen. Protein adsorption on materials surfaces with nano-topography. Chinese Science Bulletin, 2007. 52, 3169-3173.

8. J.D. Sipe. Tissue engineering and reparative medicine. Annals of the New York Academy of Sciences, 2002. 961, 1-9.

9. D.R. Schmidt, H. Waldeck, W.J. Kao. Protein Adsorption to Biomaterials. D.A. Puleo,R. Bizios, Editor. 2009, 1-18.

10. M. Salmerón-Sánchez, G. Altankov. Cell-Protein-Material interaction in tissue engineering. D. Eberli, Editor. 2010, In-Tech: 77-102.

11. P. Roach, D. Eglin, K. Rohde, C.C. Perry. Modern biomaterials: a review - bulk properties and implications of surface modifications. Journal of materials science. Materials in medicine, 2007. 18, 1263-1277.

12. J.A. Planell, M. Navarro, G. Altankov, C. Aparicio, E. Engel, J. Gil, M.P. Ginebra,D. Lacroix. Materials Surface Effect on Biological Interactions. V.P. Shastri, G. Altankov,A. Lendlein, Editor. 2010, Springer Netherlands: Dordrecht. p. 233-252.

13. H. Noh, E.a. Vogler. Volumetric interpretation of protein adsorption: competition from mixtures and the Vroman effect. Biomaterials, 2007. 28, 405-422.

14. J.L. McKenzie, T.J. Webster. Protein Interactions at Material Surfaces. R. Narayan, Editor. 2009, Springer US: Boston, MA. p. 215-237.

15. M.S. Lord, M. Foss, F. Besenbacher. Influence of nanoscale surface topography on protein adsorption and cellular response. Nano Today, 2010. 5, 66-78. 
16. H. Liu, T.J. Webster. Nanomedicine for implants: $A$ review of studies and necessary experimental tools. Biomaterials, 2007. 28, 354-369.

17. F. Grinnell. Focal adhesion sites and the removal of substratum-bound fibronectin. The Journal of cell biology, 1986. 103, 2697-2706.

18. L.G. Griffith, G. Naughton. Tissue engineering--current challenges and expanding opportunities. Science, 2002. 295, 1009-1014.

19. A.J. García. Interfaces to Control Cell-Biomaterial Adhesive Interactions. Advances in Polymer Science, 2006. 203, 171-190.

20. H. Chen, L. Yuan, W. Song, Z. Wu, D. Li. Biocompatible polymer materials: Role of protein-surface interactions. Progress in Polymer Science, 2008. 33, 1059-1087.

21. T. Ballet, L. Boulange, Y. Brechet, F. Bruckert, M. Weidenhaupt. Protein conformational changes induced by adsorption onto material surfaces : an important issue for biomedical applications of material science. Bulletin Of The Polish Academy Of Sciences Technical Sciences, 2010. 58, 303-315.

22. K. Anselme, a. Ponche, M. Bigerelle. Relative influence of surface topography and surface chemistry on cell response to bone implant materials. Part 2: biological aspects. Proceedings of the Institution of Mechanical Engineers, Part $\mathrm{H}$ : Journal of Engineering in Medicine, 2010. 224, 1487-1507.

23. R.O. Hynes. Integrins: bidirectional, allosteric signaling machines. Cell, 2002. 110, 673-687.

24. B. Geiger, A. Bershadsky, R. Pankov, K.M. Yamada. Transmembrane crosstalk between the extracellular matrix and the cytoskeleton. Nature Reviews Molecular Cell Biology, 2001. 2, 793-805.

25. A.J. García. Get a grip: integrins in cell-biomaterial interactions. Biomaterials, 2005. 26, 7525-7529.

26. J.M. Anderson. Biological Responses to Materials. Annual Review of Material Research, 2001. 31, 81-110.

27. J.Y. Wong, J.B. Leach, X.Q. Brown. Balance of chemistry, topography, and mechanics at the cell-biomaterial interface: Issues and challenges for assessing the role of substrate mechanics on cell response. Surface Science, 2004. 570, 119133.

28. I. Vakonakis, I.D. Campbell. Extracellular matrix: from atomic resolution to ultrastructure. Current opinion in cell biology, 2007. 19, 578-583. 
29. M. Larsen, V.V. Artym, J.A. Green,K.M. Yamada. The matrix reorganized: extracellular matrix remodeling and integrin signaling. Current opinion in cell biology, 2006. 18, 463-471.

30. X. Zhou, R.G. Rowe, N. Hiraoka, J.P. George, D. Wirtz, D.F. Mosher, I. Virtanen, M.A. Chernousov, S.J. Weiss. Fibronectin fibrillogenesis regulates threedimensional neovessel formation. Genes \& Development, 2008. 22, 1231-1243.

31. P. Singh, C. Carraher, J.E. Schwarzbauer. Assembly of Fibronectin Extracellular Matrix. Annual review of cell and developmental biology, 2010. 26, 397-419.

32. Y.I. Veklich, O.V. Gorkun, L.V. Medved, W. Nieuwenhuizen, J.W. Weisel. Carboxylterminal portions of the alpha chains of fibrinogen and fibrin. Localization by electron microscopy and the effects of isolated alpha $C$ fragments on polymerization. The Journal of biological chemistry, 1993. 268, 13577-13585.

33. T. Sasaki, R. Fässler, E. Hohenester. Laminin: the crux of basement membrane assembly. The Journal of cell biology, 2004. 164, 959-963.

34. C.D. Madsen, N. Sidenius. The interaction between urokinase receptor and vitronectin in cell adhesion and signalling. European journal of cell biology, 2008. 87, 617-629.

35. H. Lodish, A. Berk, S.L. Zipursky, P. Matsudaira, D. Baltimore, J. Darnell. Collagen: The Fibrous Proteins of the Matrix. 2000, W. H. Freeman and Company:

36. R.O. Hynes. Fibronectins. Springer Series in Molecular Biology. 1990, Springer New York. 1-538.

37. L. Fontana, Y. Chen, P. Prijatelj, T. Sakai, R. Fässler, L.Y. Sakai, D.B. Rifkin. Fibronectin is required for integrin $\alpha v \beta 6$-mediated activation of latent TGF- $\beta$ complexes containing LTBP-1. The FASEB journal, 2005. 19, 1798-1808.

38. E.L. George, E.N. Georges-Labouesse, R.S. Patel-King, H. Rayburn, R.O. Hynes. Defects in mesoderm, neural tube and vascular development in mouse embryos lacking fibronectin. Development, 1993. 119, 1079-1091.

39. E. Pearlstein, L.I. Gold, A. Garcia-Pardo. Fibronectin: A review of its structure and biological activity. Molecular and Cellular Biochemistry, 1980. 29, 103-128.

40. B.G. Keselowsky, D.M. Collard, A.J. García. Surface chemistry modulates fibronectin conformation and directs integrin binding and specificity to control cell adhesion. Journal of biomedical materials research. Part A, 2003. 66, 247-259.

41. A.J. García, D. Boettiger. Integrin-fibronectin interactions at the cell-material interface: initial integrin binding and signaling. Biomaterials, 1999. 20, 2427-2433. 
42. F. Grinnell, M.K. Feld. Fibronectin adsorption on hydrophilic and hydrophobic surfaces detected by antibody binding and analyzed during cell adhesion in serumcontaining medium. The Journal of biological chemistry, 1982. 257, 4888-4893.

43. G. Altankov, V. Thom, T. Groth, K. Jankova, G. Jonsson, M. Ulbricht. Modulating the biocompatibility of polymer surfaces with poly(ethylene glycol): effect of fibronectin. Journal of biomedical materials research, 2000. 52, 219-230.

44. M. Malmsten. Formation of Adsorbed Protein Layers. Journal of Colloid and Interface Science, 1998. 207, 186-199.

45. C.A. Haynes, W. Norde. Globular proteins at solid/liquid interfaces. Colloids and Surfaces B: Biointerfaces, 1994. 2, 517-566.

46. M.G.E.G. Bremer, J. Duval, W. Norde, J. Lyklema. Electrostatic interactions between immunoglobulin (IgG) molecules and a charged sorbent. Colloids and Surfaces A: Physicochemical and Engineering Aspects, 2004. 250, 29-42.

47. S. Demanèche, J.-P. Chapel, L.J. Monrozier, H. Quiquampoix. Dissimilar pHdependent adsorption features of bovine serum albumin and $\alpha$-chymotrypsin on mica probed by AFM. Colloids and Surfaces B: Biointerfaces, 2009. 70, 226-231.

48. K.L. Jones, C.R. O'Melia. Protein and humic acid adsorption onto hydrophilic membrane surfaces: effects of $\mathrm{pH}$ and ionic strength. Journal of Membrane Science, 2000. 165, 31-46.

49. D. Asthagiri, A.M. Lenhoff. Influence of Structural Details in Modeling Electrostatically Driven Protein Adsorption. Langmuir, 1997. 13, 6761-6768.

50. F.A.M. Leermakers, M. Ballauff, O.V. Borisov. On the Mechanism of Uptake of Globular Proteins by Polyelectrolyte Brushes: A Two-Gradient Self-Consistent Field Analysis. Langmuir, 2007. 23, 3937-3946.

51. A. Wittemann, M. Ballauff. Interaction of proteins with linear polyelectrolytes and spherical polyelectrolyte brushes in aqueous solution. Physical Chemistry Chemical Physics, 2006. 8, 5269-5275.

52. J. Andrade, V. Hlady. Protein adsorption and materials biocompatibility: A tutorial review and suggested hypotheses. Advances in Polymer Science 1986. 79, 1-63.

53. T.S. Tsapikouni, Y.F. Missirlis. $\mathrm{pH}$ and ionic strength effect on single fibrinogen molecule adsorption on mica studied with AFM. Colloids and surfaces. B, Biointerfaces, 2007. 57, 89-96.

54. D.G. Castner, B.D. Ratner. Biomedical surface science: Foundations to frontiers. Surface Science, 2002. 500, 28-60. 
55. M. Rabe, D. Verdes, S. Seeger. Understanding protein adsorption phenomena at solid surfaces. Advances in Colloid and Interface Science, 2011. 162, 87-106.

56. R.C. Chatelier, A.P. Minton. Adsorption of globular proteins on locally planar surfaces: models for the effect of excluded surface area and aggregation of adsorbed protein on adsorption equilibria. Biophysical Journal, 1996. 71, 23672374.

57. V. Ball, A. Lustig, J.J. Ramsden. Lag phases in the adsorption of lysozyme to $\mathrm{Si}(\mathrm{Ti}) \mathrm{O} 2$ surfaces in the presence of sodium thiocyanate. Part I. Phenomenology. Physical Chemistry Chemical Physics, 1999. 1, 3667-3671.

58. J. Comelles, M. Estévez, E. Martínez, J. Samitier. The role of surface energy of technical polymers in serum protein adsorption and MG-63 cells adhesion. Nanomedicine : nanotechnology, biology, and medicine, 2010. 6, 44-51.

59. D.J. Iuliano, S.S. Saavedra, G.A. Truskey. Effect of the conformation and orientation of adsorbed fibronectin on endothelial cell spreading and the strength of adhesion. Journal of biomedical materials research, 1993. 27, 1103-1113.

60. K.E. Michael, V.N. Vernekar, B.G. Keselowsky, J.C. Meredith, R.A. Latour, A.J. García. Adsorption-Induced Conformational Changes in Fibronectin Due to Interactions with Well-Defined Surface Chemistries. Langmuir, 2003. 19, 80338040.

61. D.E. MacDonald, N. Deo, B. Markovic, M. Stranick, P. Somasundaran. Adsorption and dissolution behavior of human plasma fibronectin on thermally and chemically modified titanium dioxide particles. Biomaterials, 2002. 23, 1269-1279.

62. G.K. Toworfe, R.J. Composto, C.S. Adams, I.M. Shapiro, P. Ducheyne. Fibronectin adsorption on surface-activated poly(dimethylsiloxane) and its effect on cellular function. Journal of biomedical materials research. Part A, 2004. 71, 449-461.

63. S.R. Sousa, M.M. Brás, P. Moradas-Ferreira, M.A. Barbosa. Dynamics of fibronectin adsorption on TiO2 surfaces. Langmuir, 2007. 23, 7046-7054.

64. C.A. Scotchford, C.P. Gilmore, E. Cooper, G.J. Leggett, S. Downes. Protein adsorption and human osteoblast-like cell attachment and growth on alkylthiol on gold self-assembled monolayers. Journal of biomedical materials research, 2002. 59, 84-99.

65. P. Rico, J. Carlos, D. Moratal, G. Altankov, M. Salmerón-Sánchez. Substrateinduced assembly of fibronectin into networks: influence of surface chemistry and effect on osteoblast adhesion. Tissue engineering. Part A, 2009. 15, 3271-3281. 
66. I.F. Amaral, M. Lamghari, S.R. Sousa, P. Sampaio, M.A. Barbosa. Rat bone marrow stromal cell osteogenic differentiation and fibronectin adsorption on chitosan membranes: the effect of the degree of acetylation. Journal of biomedical materials research. Part $A, 2005.75,387-397$.

67. C.R. Wittmer, J.A. Phelps, W.M. Saltzman. Fibronectin terminated multilayer films: protein adsorption and cell attachment studies. Biomaterials, 2007. 28, 851-860.

68. L.-C. Xu, C.A. Siedlecki. Effects of surface wettability and contact time on protein adhesion to biomaterial surfaces. Biomaterials, 2007. 28, 3273-3283.

69. R. Tzoneva, M. Heuchel, T. Groth, G. Altankov, W. Albrecht, D. Paul. Fibrinogen adsorption and platelet interactions on polymer membranes. Journal of biomaterials science. Polymer edition, 2002. 13, 1033-1050.

70. S. Tunc, M.F. Maitz, G. Steiner, L. Vázquez, M.T. Pham, R. Salzer. In situ conformational analysis of fibrinogen adsorbed on Si surfaces. Colloids and surfaces. B, Biointerfaces, 2005. 42, 219-225.

71. S.N. Rodrigues, I.C. Gonçalves, M.C.L. Martins, M.A. Barbosa, B.D. Ratner. Fibrinogen adsorption, platelet adhesion and activation on mixed hydroxyl-/methylterminated self-assembled monolayers. Biomaterials, 2006. 27, 5357-5367.

72. J.C. Rodríguez Hernández, P. Rico, D. Moratal, M. Monleón Pradas, M. SalmerónSánchez. Fibrinogen Patterns and Activity on Substrates with Tailored Hydroxy Density. Macromolecular Bioscience, 2009. 9, 766-775.

73. L. Tang, Y. Wu, R.B. Timmons. Fibrinogen adsorption and host tissue responses to plasma functionalized surfaces. Journal of biomedical materials research, 1998. 42, 156-163.

74. K. Cai, J. Bossert, K.D. Jandt. Does the nanometre scale topography of titanium influence protein adsorption and cell proliferation? Colloids and surfaces. B, Biointerfaces, 2006. 49, 136-144.

75. G. Toromanov, C. González-García, G. Altankov, M. Salmerón-Sánchez. Vitronectin activity on polymer substrates with controlled $-\mathrm{OH}$ density. Polymer, 2010. 51, 2329-2336.

76. N.M. Coelho, C. González-García, J.A. Planell, M. Salmerón-Sánchez, G. Altankov. Different assembly of type IV collagen on hydrophilic and hydrophobic substrata alters endothelial cells interaction. European cells \& materials, 2010. 19, 262-272.

77. L.T. Allen, M. Tosetto, I.S. Miller, D.P. O'Connor, S.C. Penney, I. Lynch, A.K. Keenan, S.R. Pennington, K.A. Dawson,W.M. Gallagher. Surface-induced changes 
in protein adsorption and implications for cellular phenotypic responses to surface interaction. Biomaterials, 2006. 27, 3096-3108.

78. J. Wei, M. Yoshinari, S. Takemoto, M. Hattori, E. Kawada, B. Liu, Y. Oda. Adhesion of Mouse Fibroblasts on Hexamethyldisiloxane Surfaces With Wide Range of Wettability. Journal of Biomedical Materials Research Part B: Applied Biomaterials, 2007. 81, 66-75.

79. S.R. Sousa, M. Lamghari, P. Sampaio, M.A. Barbosa. Osteoblast adhesion and morphology on TiO 2 depends on the competitive preadsorption of albumin and fibronectin. Journal of Biomedical Materials Research Part A, 2008. 84, 281-290.

80. K.L. Kilpadi, P.L. Chang, S.L. Bellis. Hydroxylapatite binds more serum proteins, purified integrins, and osteoblast precursor cells than titanium or steel. Journal of biomedical materials research, 2001. 57, 258-267.

81. J.D. Bumgardner, R. Wiser, S.H. Elder, R. Jouett, Y. Yang, J.L. Ong. Contact angle, protein adsorption and osteoblast precursor cell attachment to chitosan coatings bonded to titanium. Journal of biomaterials science. Polymer edition, 2003. $14,1401-1409$.

82. H.M. Kowalczyńska, M. Nowak-Wyrzykowska, R. Kołos, J. Dobkowski, J. Kamiński. Fibronectin adsorption and arrangement on copolymer surfaces and their significance in cell adhesion. Journal of biomedical materials research. Part A, 2005. 72, 228-236.

83. H.M. Kowalczyńska, M. Nowak-Wyrzykowska, J. Dobkowski, R. Kołos, J. Kamiński, A. Makowska-Cynka, E. Marciniak. Adsorption characteristics of human plasma fibronectin in relationship to cell adhesion. Journal of biomedical materials research, 2002. 61, 260-269.

84. A.J. García, M.D. Vega, D. Boettiger. Modulation of cell proliferation and differentiation through substrate-dependent changes in fibronectin conformation. Molecular biology of the cell, 1999. 10, 785-798.

85. S. Cheng, K.K. Chittur, C.N. Sukenik, L.A. Culp, K. Lewandowska. The conformation of fibronectin on self-assembled monolayers with different surface composition: an FTIR/ATR study. Journal of co, 1994. 162, 135-143.

86. M. Bergkvist, J. Carlsson, S. Oscarsson. Surface-dependent conformations of human plasma fibronectin adsorbed to silica, mica, and hydrophobic surfaces, studied with use of Atomic Force Microscopy. Journal of biomedical materials research. Part A, 2003. 64, 349-356. 
87. L. Baujard-Lamotte, S. Noinville, F. Goubard, P. Marque, E. Pauthe. Kinetics of conformational changes of fibronectin adsorbed onto model surfaces. Colloids and surfaces. B, Biointerfaces, 2008. 63, 129-137.

88. L. Baugh, V. Vogel. Structural changes of fibronectin adsorbed to model surfaces probed by fluorescence resonance energy transfer. Journal of biomedical materials research. Part A, 2004. 69, 525-534.

89. J.B. Lhoest, E. Detrait, P.P. Bertrand. Fibronectin adsorption, conformation, and orientation on polystyrene substrates studied by radiolabeling, XPS, and ToF SIMS. Journal of biomedical materials research, 1998. 41, 95-103.

90. P. Rico, C. González-García, T.A. Petrie, A.J. García, M. Salmerón-Sánchez. Molecular assembly and biological activity of a recombinant fragment of fibronectin (FNIII(7-10)) on poly(ethyl acrylate). Colloids and surfaces. B, Biointerfaces, 2010. 78, 310-316.

91. D. Gugutkov, G. Altankov, J. Carlos, M. Salmerón-Sánchez. Fibronectin activity on substrates with controlled --OH density. Journal of biomedical materials research. Part A, 2010. 92, 322-331.

92. C.F. Wertz, M.M. Santore. Fibrinogen Adsorption on Hydrophilic and Hydrophobic Surfaces: Geometrical and Energetic Aspects of Interfacial Relaxations. Langmuir, 2002. 18, 706-715.

93. C.F. Wertz, M.M. Santore. Effect of Surface Hydrophobicity on Adsorption and Relaxation Kinetics of Albumin and Fibrinogen: Single-Species and Competitive Behavior. Langmuir, 2001. 17, 3006-3016.

94. T.C. Ta, M.T. Sykes, M.T. McDermott. Real-Time Observation of Plasma Protein Film Formation on Well-Defined Surfaces with Scanning Force Microscopy. Langmuir, 1998. 14, 2435-2443.

95. P.S. Sit, R.E. Marchant. Surface-dependent conformations of human fibrinogen observed by atomic force microscopy under aqueous conditions. Thrombosis and haemostasis, 1999. 82, 1053-1060.

96. K.L. Marchin, C.L. Berrie. Conformational Changes in the Plasma Protein Fibrinogen upon Adsorption to Graphite and Mica Investigated by Atomic Force Microscopy. Langmuir, 2003. 19, 9883-9888.

97. A. Agnihotri, C.A. Siedlecki. Time-dependent conformational changes in fibrinogen measured by atomic force microscopy. Langmuir, 2004. 20, 8846-8852.

98. J.C. Rodríguez-Hernández, M. Salmerón-Sánchez, J.M. Soria, J.L. Gómez Ribelles,M. Monleón Pradas. Substrate chemistry-dependent conformations of 
single laminin molecules on polymer sufaces are revealed by the phase signal of atomic force microscopy. Biophysical journal, 2007. 93, 202-207.

99. F.A. Denis, A. Pallandre, B. Nysten, A.M. Jonas, C.C. Dupont-Gillain. Alignment and assembly of adsorbed collagen molecules induced by anisotropic chemical nanopatterns. Small, 2005. 1, 984-991.

100. S.E. Woodcock, W.C. Johnson, Z. Chen. Collagen adsorption and structure on polymer surfaces observed by atomic force microscopy. Journal of colloid and interface science, 2005. 292, 99-107.

101. C.C. Dupont-Gillain, P.G. Rouxhet. AFM Study of the Interaction of Collagen with Polystyrene and Plasma-Oxidized Polystyrene. Langmuir, 2001. 17, 7261-7266.

102. M.N. Sela, L. Badihi, G. Rosen, D. Steinberg, D. Kohavi. Adsorption of human plasma proteins to modified titanium surfaces. Clinical oral implants research, 2007. 18, 630-638.

103. D. Khang, S.Y. Kim, P. Liu-Snyder, G.T.R. Palmore, S.M. Durbin,T.J. Webster. Enhanced fibronectin adsorption on carbon nanotube/poly(carbonate) urethane: independent role of surface nano-roughness and associated surface energy. Biomaterials, 2007. 28, 4756-4768.

104. M.B. Hovgaard, K. Rechendorff, J. Chevallier, M. Foss, F. Besenbacher. Fibronectin adsorption on tantalum: the influence of nanoroughness. The journal of physical chemistry. B, 2008. 112, 8241-8249.

105. K. Rechendorff, M.B. Hovgaard, M. Foss, V.P. Zhdanov, F. Besenbacher. Enhancement of protein adsorption induced by surface roughness. Langmuir, 2006. 22, 10885-10888.

106. M.S. Lord, B.G. Cousins, P.J. Doherty, J.M. Whitelock, A. Simmons, R.L. Williams, B.K. Milthorpe. The effect of silica nanoparticulate coatings on serum protein adsorption and cellular response. Biomaterials, 2006. 27, 4856-4862.

107. G. Wei, P.X. Ma. Structure and properties of nano-hydroxyapatite/polymer composite scaffolds for bone tissue engineering. Biomaterials, 2004. 25, 47494757.

108. K.M. Woo, V.J. Chen, P.X. Ma. Nano-fibrous scaffolding architecture selectively enhances protein adsorption contributing to cell attachment. Journal of biomedical materials research. Part A, 2003. 67, 531-537.

109. T.J. Webster, C. Ergun, R.H. Doremus, R.W. Siegel,R. Bizios. Specific proteins mediate enhanced osteoblast adhesion on nanophase ceramics. Journal of biomedical materials research, 2000. 51, 475-483. 
110. T.J. Webster, L.S. Schadler, R.W. Siegel, R. Bizios. Mechanisms of enhanced osteoblast adhesion on nanophase alumina involve vitronectin. Tissue engineering, 2001. 7, 291-301.

111. P. Roach, D. Farrar, C.C. Perry. Surface tailoring for controlled protein adsorption: effect of topography at the nanometer scale and chemistry. Journal of the American Chemical Society, 2006. 128, 3939-3945.

112. D.C. Miller, K.M. Haberstroh, T.J. Webster. PLGA nanometer surface features manipulate fibronectin interactions for improved vascular cell adhesion. Journal of Biomedical Materials Research Part A, 2007. 81, 678-684.

113. E. Costa Martínez, J.C. Rodríguez-Hernández, M. Machado, J.F. Mano, J.L. Gómez Ribelles, M. Monleón Pradas, M. Salmerón-Sánchez. Human chondrocyte morphology, its dedifferentiation, and fibronectin conformation on different PLLA microtopographies. Tissue engineering. Part A, 2008. 14, 1751-1762.

114. D.S. Sutherland, M. Broberg, H. Nygren, B. Kasemo. Influence of Nanoscale Surface Topography and Chemistry on the Functional Behaviour of an Adsorbed Model Macromolecule. Macromolecular Bioscience, 2001. 1, 270-273.

115. F.A. Denis, P. Hanarp, D.S. Sutherland, J. Gold, C. Mustin, P.G. Rouxhet, Y.F. Dufrêne. Protein Adsorption on Model Surfaces with Controlled Nanotopography and Chemistry. Langmuir, 2002. 18, 819-828.

116. Y.F. Dufrêne, T.G. Marchal, P.G. Rouxhet. Influence of Substratum Surface Properties on the Organization of Adsorbed Collagen Films: In Situ Characterization by Atomic Force Microscopy. Langmuir, 1999. 15, 2871-2878.

117. J. Reichert, G. Wei, K.D. Jandt. Formation and Topotactical Orientation of Fibrinogen Nanofibrils on Graphite Nanostructures. Advanced Engineering Materials, 2009. 11, B177--B181.

118. D. Gugutkov, C. González-García, J. Carlos, G. Altankov, M. Salmerón-Sánchez. Biological activity of the substrate-induced fibronectin network: insight into the third dimension through electrospun fibers. Langmuir, 2009. 25, 10893-10900.

119. A.F. von Recum, T.G. van Kooten. The influence of micro-topography on cellular response and the implications for silicone implants. Journal of Biomaterials Science, Polymer Edition, 1995. 7, 181-198.

120. V.A. Schulte, M. Díez, M. Möller, M.C. Lensen. Surface topography induces fibroblast adhesion on intrinsically nonadhesive poly(ethylene glycol) substrates. Biomacromolecules, 2009. 10, 2795-2801. 
121. M. Pegueroles, C. Aparicio, M. Bosio, E. Engel, F.J. Gil, J.A. Planell, G. Altankov. Spatial organization of osteoblast fibronectin matrix on titanium surfaces: effects of roughness, chemical heterogeneity and surface energy. Acta biomaterialia, 2010. 6, 291-301.

122. S.-H. Hsu, Y.-C. Kao. Biocompatibility of poly(carbonate urethane)s with various degrees of nanophase separation. Macromolecular bioscience, 2005. 5, 246-253.

123. W.J. Kao, Q.H. Zhao, A. Hiltner, J.M. Anderson. Theoretical analysis of in vivo macrophage adhesion and foreign body giant cell formation on polydimethylsiloxane, low density polyethylene, and polyetherurethanes. Journal of biomedical materials research, 1994. 28, 73-79.

124. F.G. Giancotti. Integrin signalling. Science, 1999. 285, 1028-1032.

125. A.L. Berrier, K.M. Yamada. Cell - Matrix Adhesion. Journal of Cellular Physiology, 2007. 213, 565-573.

126. B.D. Boyan, T.W. Hummert, D.D. Dean, Z. Schwartz. Role of material surfaces in regulating bone and cartilage cell response. Biomaterials, 1996. 17, 137-146.

127. K. Anselme. Osteoblast adhesion on biomaterials. Biomaterials, 2000. 21, 667-681.

128. C.S. Izzard, L.R. Lochner. Cell-to-substrate contacts in living fibroblasts: an interference reflexion study with an evaluation of the technique. Journal of Cell Science, 1976. 21, 129-159.

129. E. Zamir, B. Geiger. Molecular complexity and dynamics of cell-matrix adhesions. Journal of Cell Science, 2001. 114, 3583-3590.

130. S.K. Sastry, K. Burridge. Focal adhesions: A nexus for intracellular signaling and cytoskeletal dynamics. Experimental Cell Research, 2000. 261, 25-36.

131. M. Abercrombie, G.A. Dunn. Adhesions of fibroblasts to substratum during contact inhibition observed by interference reflection microscopy. Experimental Cell Research, 1975. 92, 57-62.

132. M.A. Schwartz. Integrins and Extracellular Matrix in Mechanotransduction. Cold Spring Harbor perspectives in biology, 2010.

133. K. Rottner, A. Hall, J.V. Small. Interplay between rac and rho in the control of substrate contact dynamics. Current biology, 1999. 9, 640-648.

134. C.D. Nobes, A. Hall. Rho, rac, and cdc42 GTPases regulate the assembly of multimolecular focal complexes associated with actin stress fibers, lamellipodia, and filopodia. Cell, 1995. 81, 53-62. 
135. E. Zamir, M. Katz, Y. Posen, N. Erez, K.M. Yamada, B.Z. Katz, S. Lin, D.C. Lin, A. Bershadsky, Z. Kam, B. Geiger. Dynamics and segregation of cell-matrix adhesions in cultured fibroblasts. Nature Cell Biology, 2000. 2, 191-196.

136. E. Zamir, B.Z. Katz, S. Aota, K.M. Yamada, B. Geiger, Z. Kam. Molecular diversity of cell-matrix adhesions. Journal of Cell Science, 1999. 112, 1655-1669.

137. W.T. Chen, S.J. Singer. Immunoelectron microscopic studies of the sites of cellsubstratum and cell-cell contacts in cultured fibroblasts. Journal of Cell Biology, 1982. 95, 205-222.

138. S. Lin, D. Lin. Mapping of actin, vinculin, and integrin binding domains suggests a direct role of tensin in actin-membrane association. Molecular biology of the cell, 1996. 7 (suppl), 389a-389a.

139. D.C. Han, L.G. Rodriguez, J.L. Guan. Identification of a novel interaction between integrin $\beta 1$ and 14-3-3 3 . Oncogene, 2000. 20, 346-357.

140. S.K. Hanks, M.B. Calalb, M.C. Harper, S.K. Patel. Focal adhesion protein-tyrosine kinase phosphorylated in response to cell attachment to fibronectin. Proceedings of the National Academy of Sciences of the United States of America, 1992. 89, 84878491.

141. M.D. Schaller, C.A. Borgman, B.S. Cobb, R.R. Vines, A.B. Reynolds, J.T. Parsons. pp125FAK, a structurally distinctive protein-tyrosine kinase associated with focal adhesions. Proceedings of the National Academy of Sciences of the United States of America, 1992. 89, 5192-5196.

142. G.W. McLean, N.O. Carragher, E. Avizienyte, J. Evans, V.G. Brunton, M.C. Frame. The role of focal-adhesion kinase in cancer - a new therapeutic opportunity. Nature reviews. Cancer, 2005. 5, 505-515.

143. D.A. Hsia, S.K. Mitra, C.R. Hauck, D.N. Streblow, J.A. Nelson, D. Ilic, S. Huang, E. Li, G.R. Nemerow, J. Leng, K.S.R. Spencer, D.A. Cheresh, D.D. Schlaepfer. Differential regulation of cell motility and invasion by FAK. Cell, 2003. 753-767.

144. T-L. Shen, A.Y.J. Park, A. Alcaraz, X. Peng, I. Jang, P. Koni, R.A. Flavell, H. Gu, JL. Guan. Conditional knockout of focal adhesion kinase in endothelial cells reveals its role in angiogenesis and vascular development in late embryogenesis. The Journal of cell biology, 2005. 169, 941-952.

145. J.T. Parsons. Focal adhesion kinase: the first ten years. Journal of Cell Science, 2003. 116, 1409-1416.

146. S.K. Mitra, D.A. Hanson, D.D. Schlaepfer. Focal adhesion kinase: in command and control of cell motility. Nature reviews. Molecular cell biology, 2005. 6, 56-68. 
147. R. Braren, H. Hu, Y.H. Kim, H.E. Beggs, L.F. Reichardt, R. Wang. Endothelial FAK is essential for vascular network stability, cell survival, and lamellipodial formation. The Journal of cell biology, 2006. 172, 151-162.

148. H.E. Beggs, D. Schahin-reed, K. Zang, S. Goebbels, K.A. Nave, J. Gorski, K.R. Jones, D. Sretavan, L.F. Reichardt. FAK deficiency in cells contributing to the basal lamina results in cortical abnormalities resembling congenital muscular dystrophies. Neuron, 2003. 40, 501-514.

149. D. Ilic, Y. Furuta, S. Kanazawa, N. Takeda, K. Sobue, N. Nakatsuji, S. Nomura, J. Fujimoto, M. Okada, T. Yamamoto, S. Aizawa. Reduced cell motility and enhanced focal adhesion contact formation in cells from FAK-deficient mice. Nature, 1995. 377, 539-544.

150. M. Luo, J.-I. Guan. Focal adhesion kinase: A prominent determinant in breast cancer initiation, progression and metastasis. Cancer Letters, 2010. 289, 127-139.

151. J.M. Dunty, V. Gabarra-niecko, M.L. King, D.F.J. Ceccarelli, M.J. Eck, M.D. Schaller. FERM Domain Interaction Promotes FAK Signaling. Molecular and cellular biology, 2004. 24, 5353-5368.

152. L.A. Cooper, T.-I. Shen, J.-I. Guan. Regulation of Focal Adhesion Kinase by Its Amino-Terminal Domain through an Autoinhibitory Interaction. Society, 2003. 23, 8030-8041.

153. L.A. Cohen, J.-L. Guan. Residues within the first subdomain of the FERM-like domain in focal adhesion kinase are important in its regulation. The Journal of biological chemistry, 2005. 280, 8197-8207.

154. M.D. Schaller, J.D. Hildebrand, J.D. Shannon, J.W. Fox, R.R. Vines, J.T. Parsons. Autophosphorylation of the focal adhesion kinase, pp125FAK, directs DH2dependent binding of pp60src. Molecular and cellular biology, 1994. 14, 1680-1688.

155. D.D. Schlaepfer, M.A. Broome, T. Hunter. Fibronectin-stimulated signaling from a focal adhesion kinase-c-Src complex: Involvement of the Grb2, p130cas, and Nck adaptor proteins. Molecular and cellular biology, 1997. 17, 1702-1713.

156. P.J. Ruest, S. Roy, E. Shi, R.L. Mernaugh, S.K. Hanks. Phosphospecific antibodies reveal focal adhesion kinase activation loop phosphorylation in nascent and mature focal adhesions and requirement for the autophosphorylation site. Cell growth \& differentiation : the molecular biology journal of the American Association for Cancer Research, 2000. 11, 41-48.

157. J.D. Owen, P.J. Ruest, D.W. Fry, S.K. Hanks. Induced focal adhesion kinase (FAK) expression in FAK-null cells enhances cell spreading and migration requiring both 
auto- and activation loop phosphorylation sites and inhibits adhesion-dependent tyrosine phosphorylation of Pyk2. Molecular and cellular biology, 1999. 19, 48064818.

158. C.B. Khatiwala, S.R. Peyton, A.J. Putnam. Intrinsic mechanical properties of the extracellular matrix affect the behavior of pre-osteoblastic MC3T3-E1 cells. American Journal of Physiology. Cell Physiology, 2006. 6, C1640--C1650.

159. M.T. Frey, I.Y. Tsai, T.P. Russell, S.K. Hanks, Y.-L. Wang. Cellular responses to substrate topography: role of myosin II and focal adhesion kinase. Biophysical journal, 2006. 90, 3774-3782.

160. B.G. Keselowsky, L. Wang, Z. Schwartz, A.J. Garcia, B.D. Boyan. Integrin alpha5 controls osteoblastic proliferation and differentiation responses to titanium substrates presenting different roughness characteristics in a roughness independent manner. Journal of Biomedical Materials Research. Part A, 2006. 80, 700-710.

161. J.Y. Lim, A.D. Dreiss, Z. Zhou, J.C. Hansen, C.A. Siedlecki, R.W. Hengstebeck, J. Cheng, N. Winograd, H.J. Donahue. The regulation of integrin-mediated osteoblast focal adhesion and focal adhesion kinase expression by nanoscale topography. Biomaterials, 2007. 28, 1787-1797.

162. B.G. Keselowsky, D.M. Collard, A.J. García. Surface chemistry modulates focal adhesion composition and signaling through changes in integrin binding. Biomaterials, 2004. 25, 5947-5954.

163. A.M. Moursi, R.K. Globus, C.H. Damsky. Interactions between integrin receptors and fibronectin are required for calvarial osteoblast differentiation in vitro. Journal of cell science, 1997. 110, 2187-2196.

164. V. Llopis, P. Rico, J. Ballester, D. Moratal, M. Salmerón-Sánchez. Role of surface chemistry in protein remodelling at the cell-material interface. Plos one, 2011.

165. H. Zhang, C.-y. Lin,S.J. Hollister. The interaction between bone marrow stromal cells and RGD-modi ed three-dimensional porous polycaprolactone scaffolds. Biomaterials, 2009. 30, 4063-4069.

166. T.A. Petrie, J.R. Capadona, C.D. Reyes, A.J. García. Integrin specificity and enhanced cellular activities associated with surfaces presenting a recombinant fibronectin fragment compared to RGD supports. Biomaterials, 2006. 27, 54595470 . 
167. P. Zapata, J. Su, A.J. García, J.C. Meredith. Quantitative high-throughput screening of osteoblast attachment, spreading, and proliferation on demixed polymer blend micropatterns. Biomacromolecules, 2007. 8, 1907-1917.

168. M. Padial-Molina, P. Galindo-Moreno, J.E. Fernández-Barbero, F. O'Valle, A.B. Jódar-Reyes, J.L. Ortega-Vinuesa, P.J. Ramón-Torregrosa. Role of wettability and nanoroughness on interactions between osteoblast and modified silicon surfaces. Acta biomaterialia, 2011. 7, 771-778.

169. M.A. Lan, C.A. Gersbach, K.E. Michael, B.G. Keselowsky, A.J. García. Myoblast proliferation and differentiation on fibronectin-coated self assembled monolayers presenting different surface chemistries. Biomaterials, 2005. 26, 4523-4531.

170. B.G. Keselowsky, D.M. Collard, A.J. García. Integrin binding specificity regulates biomaterial surface chemistry effects on cell differentiation. Proceedings of the National Academy of Sciences of the United States of America, 2005. 102, 59535957.

171. J.E. Phillips, T.A. Petrie, F.P. Creighton, A.J. García. Human mesenchymal stem cell differentiation on self-assembled monolayers presenting different surface chemistries. Acta biomaterialia, 2010. 6, 12-20.

172. J. Tan,W.M. Saltzman. Biomaterials with hierarchically defined micro- and nanoscale structure. Biomaterials, 2004. 25, 3593-3601.

173. S. Lossdorfer, Z. Schwartz, L. Wang, C.H. Lohman, J.D. Turner, M. Wieland, D.L. Cochran, B.D. Boyan. Microrough implant surface topographies increase osteogenesis by reducing osteoclast formation and activity. Journal of Biomedical Materials Research Part A, 2004. 70, 361-369.

174. G.B. Schneider, H. Perinpanayagam, M. Clegg, R. Zaharias, D. Seabold, J. Keller, C. Stanford. Implant surface roughness affects osteoblast gene expression. Journal of Dental Research, 2003. 82, 372-376.

175. T. Sjostrom, M.J. Dalby, A. Hart, R. Tare, R.O. Oreffo, B. Su. Fabrication of pillarlike titania nanostructures on titanium and their interactions with human skeletal stem cells. Acta Biomaterialia, 2009. 5, 1433-1441.

176. M.J. Dalby, S.J. Yarwood, M.O. Riehle, H.J. Johnstone, S. Affrossman, A.S. Curtis. Increasing fibroblast response to materials using nanotopography: morphological and genetic measurements of cell response to 13-nm-high polymer demixed islands. Experimental Cell Research, 2002. 276, 1-9. 
177. M.J. Dalby, N. Gadegaard, C.D. Wilkinson. The response of fibroblasts to hexagonal nanotopography fabricated by electron beam lithography. Journal of Biomedical Materials Research Part A, 2008. 84, 973-979.

178. M.J.P. Biggs, R.G. Richards, N. Gadegaard, C.D.W. Wilkinson, M.J. Dalby. Regulation of implant surface cell adhesion: characterization and quantification of S-phase primary osteoblast adhesions on biomimetic nanoscale substrates. Journal of Orthopaedic Research, 2007. 25, 273-282.

179. M.J. Dalby, N. Gadegaard, R. Tare, A. Andar, M.O. Riehle, P. Herzyk, C.D.W. Wilkinson, R.O.C. Oreffo. The control of human mesenchymal cell differentiation using nanoscale symmetry and disorder. Nature materials, 2007. 6, 997-1003.

180. A. Curtis,C. Wilkinson. Topographical control of cells. Biomaterials, 1997. 18, 15731583.

181. A. Mata, C. Boehm, A.J. Fleischman, G. Muschler, S. Roy. Growth of connective tissue progenitor cells on microtextured polydimethylsiloxane surfaces. Journal of biomedical materials research, 2002. 62, 499-506.

182. J. Tan, H. Shen, K.L. Carter, W.M. Saltzman. Controlling human polymorphonuclear leukocytes motility using microfabrication technology. Journal of biomedical materials research, 2000. 51, 694-702.

183. M.J. Dalby, M.O. Riehle, S.J. Yarwood, C.D. Wilkinson, A.S. Curtis. Nucleus alignment and cell signaling in fibroblasts: response to a micro-grooved topography. Experimental Cell Research, 2003. 284, 274-282.

184. S. Lenhert, M.B. Meier, U. Meyer, L. Chi, H.P. Wiesmann. Osteoblast alignment, elongation and migration on grooved polystyrene surfaces patterned by LangmuirBlodgett lithography. Biomaterials, 2005. 26, 563-570.

185. E.K. Yim, S.W. Pang, K.W. Leong. Synthetic nanostructures inducing differentiation of human mesenchymal stem cells into neuronal lineage. Experimental Cell Research, 2007. 313, 1820-1829.

186. M.J. Dalby, D. McCloy, M. Robertson, C.D. Wilkinson, R.O. Oreffo. Osteoprogenitor response to defined topographies with nanoscale depths. Biomaterials, 2006. 27, 1306-1315.

187. S.A. Biela, Y. Su, J.P. Spatz, R. Kemkemer. Different sensitivity of human endothelial cells, smooth muscle cells and fibroblasts to topography in the nanomicro range. Acta Biomaterialia, 2009. 5, 2460-2466. 
188. W.A. Loesberg, J. te Riet, F.C. van Delft, P. Schon, C.G. Figdor, S. Speller. The threshold at which substrate nanogroove dimensions may influence fibroblast alignment and adhesion. Biomaterials, 2007. 28, 3944-3951.

189. M.J.P. Biggs, R.G. Richards, M.J. Dalby. Nanotopographical modification: a regulator of cellular function through focal adhesions. Nanomedicine : nanotechnology, biology, and medicine, 2010. 6, 619-633.

190. C.M. Lo, H.B. Wang, M. Dembo, Y.L. Wang. Cell movement is guided by the rigidity of the substrate. Biophysical journal, 2000. 79, 144-152.

191. A.J. Engler, M.A. Griffin, S. Sen, C.G. Bönnemann, H.L. Sweeney, D.E. Discher. Myotubes differentiate optimally on substrates with tissue-like stiffness. The Journal of Cell Biology, 2004. 166, 877-887.

192. S.R. Peyton, A.J. Putnam. Extracellular matrix rigidity governs smooth muscle cell motility in a biphasic fashion. Journal of Cellular Physiology, 2005. 204, 198-209.

193. W.-h. Guo, M.T. Frey, N.A. Burnham, Y.-I. Wang. Substrate Rigidity Regulates the Formation and Maintenance of Tissues. Biophysical Journal, 2006. 90, 2213-2220.

194. K. Ghosh, Z. Pan, E. Guan, S. Ge, Y. Liu, T. Nakamura, X.-D. Ren, M. Rafailovich, R.A.F. Clark. Cell adaptation to a physiologically relevant ECM mimic with different viscoelastic properties. Biomaterials, 2007. 28, 671-679.

195. P.L. Ryan, R.A. Foty, J. Kohn, M.S. Steinberg. Tissue spreading on implantable substrates is a competitive outcome of cell-cell vs. cell-substratum adhesivity. Proceedings of the National Academy of Sciences of the United States of America, 2001. 98, 4282-4284.

196. D.E. Discher, P. Janmey, Y.-I. Wang. Tissue Cells Feel and Respond to the Stiffness of Their Substrate. Science, 2005. 310, 1139-1143.

197. A. Schneider, G. Francius, R. Obeid, P. Schwinté, J. Hemmerlé, B. Frisch, P. Schaaf, J.-C. Voegel, B. Senger, C. Picart. Polyelectrolyte Multilayers with a Tunable Young's Modulus: Influence of Film Stiffness on Cell Adhesion. Langmuir, 2005. 22, 1193-1200.

198. R.J. Pelham, Y.-I. Wang. Cell locomotion and focal adhesions are regulated by substrate flexibility. Proceedings of the National Academy of Sciences, 1997. 94, 13661-13665.

199. A.J. Engler, S. Sen, H.L. Sweeney, D.E. Discher. Matrix Elasticity Directs Stem Cell Lineage Specification. Cell, 2006. 126, 677-689. 
200. I.B. Bischofs, U.S. Schwarz. Cell organization in soft media due to active mechanosensing. Proceedings of the National Academy of Sciences of the United States of America, 2003. 16, 9274-9279.

201. N.G. Genes, J.A. Rowley, D.J. Mooney, L.J. Bonassar. Effect of substrate mechanics on chondrocyte adhesion to modified alginate surfaces. Archives of Biochemistry and Biophysics, 2004. 422, 161-167.

202. A. Schneider, G. Francius, R. Obeid, P. Schwinté, J. Hemmerlé, B. Frisch, P. Schaaf, J.C. Voegel, B. Senger, C. Picart. Polyelectrolyte multilayers with a tunable Young's modulus: influence of film stiffness on cell adhesion. Langmuir, 2006. 3, 1193-1200.

203. G. De Santis, A.B. Lennon, F. Boschetti, B. Verhegghe, P. Verdonck, P.J. Prendergast. How can cells sense the elasticity of a substrate? An analysis using a cell tensegrity model. European Cells and Materials, 2011. 22, 202-213.

204. T. Yeung, P.C. Georges, L.A. Flanagan, B. Marg, M. Ortiz, M. Funaki, N. Zahir, W. Ming, V. Weaver, P.A. Janmey. Effects of substrate stiffness on cell morphology, cytoskeletal structure, and adhesion. Cell Motility and the Cytoskeleton, 2005. 60, 24-34.

205. J.M. Maloney, E.B. Walton, C.M. Bruce, K.J. Van Vliet. Influence of finite thickness and stiffness on cellular adhesion-induced deformation of compliant substrata. Physical review. E, Statistical, nonlinear, and soft matter physics, 2008. 78, 041923.

206. A. Buxboim, K. Rajagopal, A.E.X. Brown, D.E. Discher. How deeply cells feel: methods for thin gels. Journal of Physics: Condensed Matter, 2010. 22, 194116.

207. H.J. Kong, T.R. Polte, E. Alsberg, D.J. Mooney. FRET measurements of celltraction forces and nano-scale clustering of adhesion ligands varied by substrate stiffness. Proceedings of the National Academy of Sciences of the United States of America, 2005. 12, 4300-4305.

208. V.A. Schulte, M. Diez, Y. Hu, M. Möller, M.C. Lensen. Combined influence of substrate stiffness and surface topography on the antiadhesive properties of Acr$s P(E O-s t a t-P O)$ hydrogels. Biomacromolecules, 2010. 11, 3375-3383.

209. G. Altankov, T. Groth. Reorganization of substratum-bound fibronectin on hydrophilic and hydrophobic materials is related to biocompatibility. Journal of Materials Science: Materials in Medicine, 1994. 5, 732-737.

210. Z. Avnur, B. Geiger. The removal of extracellular fibronectin from areas of cellsubstrate contact. Cell, 1981. 25, 121-132. 
211. S. Rhee, F. Grinnell. Fibroblast mechanics in $3 D$ collagen matrices. Advanced drug delivery reviews, 2007. 59, 1299-1305.

212. L. Kolácná, J. Bakesová, F. Varga, E. Kostáková, L. Plánka, A. Necas, D. Lukás, E. Amler, V. Pelouch. Biochemical and biophysical aspects of collagen nanostructure in the extracellular matrix. Physiological research, 2007. 56 Suppl 1, S51--S60.

213. L. Maneva-Radicheva, U. Ebert, N. Dimoudis, G. Altankov. Fibroblast remodeling of adsorbed collagen type IV is altered in contact with cancer cells. Histology and histopathology, 2008. 23, 833-842.

214. G. Altankov, T. Groth, N. Krasteva, W. Albrecht, D. Paul. Morphological evidence for a different fibronectin receptor organization and function during fibroblast adhesion on hydrophilic and hydrophobic glass substrata. Journal of biomaterials science. Polymer edition, 1997. 8, 721-740.

215. R. Tzoneva, T. Groth, G. Altankov, D. Paul. Remodeling of fibrinogen by endothelial cells in dependence on fibronectin matrix assembly. Effect of substratum wettability. Journal of materials science. Materials in medicine, 2002. $13,1235-1244$.

216. G. Altankov, F. Grinnell, T. Groth. Studies on the biocompatibility of materials: fibroblast reorganization of substratum-bound fibronectin on surfaces varying in wettability. Journal of biomedical materials research, 1996. 30, 385-391.

217. T. Pompe, K. Keller, C. Mitdank, C. Werner. Fibronectin fibril pattern displays the force balance of cell-matrix adhesion. European biophysics journal, 2005. 34, 10491056.

218. G. Altankov, T. Groth. Fibronectin matrix formation biocompatibility of materials. Journal of Materials Science: Materials in Medicine, 1996. 7, 425-429.

219. Y. Arima, H. Iwata. Effect of wettability and surface functional groups on protein adsorption and cell adhesion using well-defined mixed self-assembled monolayers. Biomaterials, 2007. 28, 3074-3082.

220. M. Salmerón-Sánchez, P. Rico, D. Moratal, T. Lee, J.E. Schwarzbauer, A.J. García. Role of material-driven fibronectin fibrillogenesis in cell differentiation. Biomaterials, 2011. 32, 2099-2105.

221. R.A. Wagenaar-Miller, L.H. Engelholm, J. Gavard, S.S. Yamada, J.S. Gutkind, N. Behrendt, T.H. Bugge, K. Holmbeck. Complementary roles of intracellular and pericellular collagen degradation pathways in vivo. Molecular and cellular biology, 2007. 27, 6309-6322. 
222. R. Schofield. The relationship between the spleen colony-forming cell and the haemopoietic stem cell. Blood cells, 1978. 4, 7-25.

223. J. Sottile, D.C. Hocking. Fibronectin Polymerization Regulates the Composition and Stability of Extracellular Matrix Fibrils and Cell-Matrix Adhesions. Molecular Biology of the Cell, 2002. 13, 3546-3559.

224. D.F. Mosher, J. Sottile, C. Wu, J.A. McDonald. Assembly of extracellular matrix. Current opinion in cell biology, 1992. 4, 810-818.

225. R.A. Christopher, A.P. Kowalczyk, P.J. McKeown-Longo. Localization of fibronectin matrix assembly sites on fibroblasts and endothelial cells. Journal of cell science, 1997. 110, 569-581.

226. B.J. Dzamba, H. Wu, R. Jaenisch, D.M. Peters. Fibronectin binding site in type I collagen regulates fibronectin fibril formation. The Journal of cell biology, 1993. 121, 1165-1172.

227. M. Pereira, B.J. Rybarczyk, T.M. Odrljin, D.C. Hocking, J. Sottile, P.J. SimpsonHaidaris. The incorporation of fibrinogen into extracellular matrix is dependent on active assembly of a fibronectin matrix. Journal of cell science, 2002. 115, 609-617.

228. G. Guadiz, L.A. Sporn, P.J. Simpson-Haidaris. Thrombin Cleavage-Independent Deposition of Fibrinogen in Extracellular Matrices. Blood, 1997. 90, 2644-2653.

229. K. Holmbeck, P. Bianco, J. Caterina, S. Yamada, M. Kromer, S.A. Kuznetsov, M. Mankani, P.G. Robey, a.R. Poole, I. Pidoux, J.M. Ward, H. Birkedal-Hansen. MT1MMP-deficient mice develop dwarfism, osteopenia, arthritis, and connective tissue disease due to inadequate collagen turnover. Cell, 1999. 99, 81-92.

230. S. Heymans, M. Pauschinger, Armando, A. Kallwellis-Opara, S. Rutschow, M. Swinnen, D. Vanhoutte, F. Gao, R. Torpai, A.H. Baker, E. Padalko, J. Neyts, H.-P. Schultheiss, Frans, P. Carmeliet, Y.M. Pinto. Inhibition of urokinase-type plasminogen activator or matrix metalloproteinases prevents cardiac injury and dysfunction during viral myocarditis. Circulation, 2006. 114, 565-573.

231. A. Reisenauer, O. Eickelberg, A. Wille, A. Heimburg, A. Reinhold, B.F. Sloane, T. Welte, F. Bühling. Increased carcinogenic potential of myeloid tumor cells induced by aberrant TGF- $\beta 1$-signaling and upregulation of cathepsin B. Biological Chemistry, 2007. 388, 639-650.

232. A.C. Curino, L.H. Engelholm, S.S. Yamada, K. Holmbeck, L.R. Lund, A.A. Molinolo, N. Behrendt, B.S. Nielsen, T.H. Bugge. Intracellular collagen degradation mediated by UPARAP/Endo180 is a major pathway of extracellular matrix turnover during malignancy. The Journal of cell biology, 2005. 169, 977-985. 
233. M.M. Mohamed, B.F. Sloane. Cysteine cathepsins: multifunctional enzymes in cancer. Nature Reviews. Cancer, 2006. 6, 764-775.

234. J.E. Koblinski, M. Ahram, B.F. Sloane. Unraveling the role of proteases in cancer. Clinica chimica acta, 2000. 291, 113-135.

235. A. Page-McCaw, A.J. Ewald, Z. Werb. Matrix metalloproteinases and the regulation of tissue remodelling. Nature Reviews Molecular Cell Biology, 2007. 8, 221-233.

236. M.R. Buck, D.G. Karustis, N.a. Day, K.V. Honn, B.F. Sloane. Degradation of extracellular-matrix proteins by human cathepsin $B$ from normal and tumour tissues. The Biochemical journal, 1992. 282, 273-278.

237. E. Hadler-Olser, B. Fadnes, I. Sylte, L. Uhlin-Hansen, J. Winberg. Regulation of matrix metalloproteinase activity in health and disease. FEBS Journal, 2011. 278, 28-45.

238. M. Uchida, M. Shima, T. Shimoaka, A. Fujieda, K. Obara, H. Suzuki, Y. Nagai, T. Ikeda, H. Yamato, H. Kawaguchi. Regulation of Matrix Metalloproteinases (MMPs) and Tissue Inhibitors of Metalloproteinases ( TIMPs) by Bone Resorptive Factors in Osteoblastic Cells. Journal of cellular physiology, 2000. 185, 207-214.

239. C.-M. Yang, C.-S. Chien, C.-C. Yao, L.-D. Hsiao, Y.-C. Huang, C.B. Wu. Mechanical strain induces collagenase-3 (MMP-13) expression in MC3T3-E1 osteoblastic cells. The Journal of biological chemistry, 2004. 279, 22158-22165.

240. R. Wan, Y. Mo, X. Zhang, S. Chien, D.J. Tollerud, Q. Zhang. Matrix metalloproteinase-2 and -9 are induced differently by metal nanoparticles in human monocytes: The role of oxidative stress and protein tyrosine kinase activation. Toxicology and applied pharmacology, 2008. 233, 276-285.

241. H.A. Kenny, S. Kaur, L.M. Coussens, E. Lengyel. The initial steps of ovarian cancer cell metastasis are mediated by MMP-2 cleavage of vitronectin and fibronectin. The Journal of Clinical Investigation, 2008. 118, 1367-1379.

242. R. Pankov, K.M. Yamada. Fibronectin at a glance. Journal of Cell Science, 2002. 115, 3861-3863.

243. J. Cho, D.F. Mosher. Role of fibronectin assembly in platelet thrombus formation. Journal of thrombosis and haemostasis, 2006. 4, 1461-1469.

244. H. Ni, P.S.T. Yuen, J.M. Papalia, J.E. Trevithick, T. Sakai, R. Fässler, R.O. Hynes, D.D. Wagner. Plasma fibronectin promotes thrombus growth and stability in injured arterioles. Proceedings of the National Academy of Sciences of the United States of America, 2003. 100, 2415-2419. 
245. Y. Mao, J.E. Schwarzbauer. Fibronectin fibrillogenesis, a cell-mediated matrix assembly process. Matrix Biology, 2005. 24, 389-399.

246. P. Singh, C. Carraher, J.E. Schwarzbauer. Assembly of Fibronectin Extracellular Matrix. Annual Review of Cell and Developmental Biology, 2010. 26, 397-419.

247. J.E. Schwarzbauer. Fibronectin: from gene to protein. Current opinion in cell biology, 1991. 3, 786-791.

248. J.-L. Guan, R.O. Hynes. Lymphoid cells recognize an alternatively spliced segment of fibronectin via the integrin receptor $\alpha 4 \beta 1$. Cell, 1990. 60, 53-61.

249. M. Leiss, K. Beckmann, A. Girós, M. Costell, R. Fässler. The role of integrin binding sites in fibronectin matrix assembly in vivo. Current Opinion in Cell Biology, 2008. 20, 502-507.

250. J. Sottile, J. Schwarzbauer, J. Selegue, D.F. Mosher. Five type I modules of fibronectin form a functional unit that binds to fibroblasts and Staphylococcus aureus. The Journal of biological chemistry, 1991. 266, 12840-12843.

251. E. Ruoslahti, B. Obrink. Common principles in cell adhesion. Experimental cell research, 1996. 227, 1-11.

252. J.A. McDonald, B.J. Quade, T.J. Broekelmann, R. LaChance, K. Forsman, E. Hasegawa, S. Akiyama. Fibronectin's cell-adhesive domain and an amino-terminal matrix assembly domain participate in its assembly into fibroblast pericellular matrix. Journal of Biological Chemistry, 1987. 262, 2957-2967.

253. F.J. Fogerty, S.K. Akiyama, K.M. Yamada, D.F. Mosher. Inhibition of binding of fibronectin to matrix assembly sites by anti-integrin (alpha 5 beta 1) antibodies. The Journal of cell biology, 1990. 111, 699-708.

254. J.L. Sechler, S.A. Corbett, J.E. Schwarzbauer. Modulatory roles for integrin activation and the synergy site of fibronectin during matrix assembly. Molecular biology of the cell, 1997. 8, 2563-2573.

255. C. Wu, V.M. Keivenst, T.E. O'Toole, J.A. McDonald, M.H. Ginsberg. Integrin activation and cytoskeletal interaction are essential for the assembly of a fibronectin matrix. Cell, 1995. 83, 715-724.

256. K. Wennerberg, L. Lohikangas, D. Gullberg, M. Pfaff, S. Johansson, R. Fässler. $\beta 1$ Integrin-dependent and -independent Polymerization of Fibronectin. The Journal of cell biology, 1996. 132, 227-238.

257. J.T. Yang, B.L. Bader, J.A. Kreidberg, M. Ullman-Culleré, J.E. Trevithick, R.O. Hynes. Overlapping and independent functions of fibronectin receptor integrins in early mesodermal development. Developmental biology, 1999. 215, 264-277. 
258. M. Leiss, K. Beckmann, A. Girós, M. Costell, R. Fässler. The role of integrin binding sites in fibronectin matrix assembly in vivo. Current opinion in cell biology, 2008. 20, 502-507.

259. F. Curnis, R. Longhi, L. Crippa, A. Cattaneo, E. Dondossola, A. Bachi, A. Corti. Spontaneous formation of L-isoaspartate and gain of function in fibronectin. The Journal of biological chemistry, 2006. 281, 36466-36476.

260. K.J. Johnson, H. Sage, G. Briscoe, H.P. Erickson. The compact conformation of fibronectin is determined by intramolecular ionic interactions. The Journal of biological chemistry, 1999. 274, 15473-15479.

261. A. Hall. Rho GTPases and the control of cell behaviour. Biochemical Society Transactions, 2005. 33, 891-895.

262. A. Yoneda, D. Ushakov, H.A.B. Multhaupt, J.R. Couchman. Fibronectin Matrix Assembly Requires Distinct Contributions from Rho Kinases I and -II. Molecular Biology of the Cell, 2007. 18, 66-75.

263. F. Shi, J. Sottile. Caveolin-1-dependent $\beta 1$ integrin endocytosis is a critical regulator of fibronectin turnover. Journal of cell science, 2008. 121, 2360-2371.

264. J.A. Green, A.L. Berrier, R. Pankov, K.M. Yamada. $\beta 1$ Integrin Cytoplasmic Domain Residues Selectively Modulate Fibronectin Matrix Assembly and Cell Spreading through Talin and Akt. Journal of Biological Chemistry, 2009. 284, 8148-8159.

265. I. Wierzbicka-Patynowski, Y. Mao, J.E. Schwarzbauer. Continuous Requirement for pp60-Src and Phospho-Paxillin During Fibronectin Matrix Assembly by Transformed Cells. Journal of Cellular Physiology, 2007. 210, 750-756.

266. F. Shi, J. Sottile. Caveolin-1-dependent $\beta 1$ integrin endocytosis is a critical regulator of fibronectin turnover. Journal of Cell Science, 2008. 121, 2360-2371.

267. E.C. Williams, P.A. Janmeyn, R.B. Johnson, F. Mosher. Fibronectin. Effect of disulfide bond reduction on its physical and functional properties. The Journal of biological chemistry, 1983. 258, 5911-5914.

268. K. Sakai, T. Fujii, T. Hayashi. Cell-free formation of disulfide-bonded multimer from isolated plasma fibronectin in the presence of a low concentration of $\mathrm{SH}$ reagent under a physiological condition. Journal of biochemistry, 1994. 115, 415-421.

269. T. Vartio. Disulfide-bonded polymerization of plasma fibronectin in the presence of metal ions. The Journal of biological chemistry, 1986. 261, 9433-9437.

270. D.M.P. Peters, Y. Chen, L. Zardi, S. Brummel. Conformation of fibronectin fibrils varies: Discrete globular domains of type III repeats detected. Microscopy and Microanalysis, 1998. 4, 385-396. 
271. Y. Chen, L. Zardi, D.M.P. Peters. High-resolution cryo-scanning electron microscopy study of the macromolecular structure of fibronectin fibrils. Scanning, 1997. 19, 349-355.

272. D.F. Mosher, R.B. Johnson. In vitro formation of disulfide-bonded fibronectin multimers. The Journal of biological chemistry, 1983. 258, 6595-6601.

273. M. Vuento, T. Vartio, M. Saraste, C.H. von Bonsdorff, A. Vaheri. Spontaneous and polyamine-induced formation of filamentous polymers from soluble fibronectin. European journal of biochemistry, 1980. 105, 33-42.

274. M. Vuento, E. Salonen, P. Riepponen. Interaction of polyamines with proteins of human plasma: a preferential aggregation of fibrinogen and fibronectin (cold insoluble globulin). Biochimie, 1980. 62, 99-104.

275. H. Richter, C. Wendt, H. Hörmann. Aggregation and Fibril Formation of Plasma Fibronectin by Heparin. Biological Chemistry Hoppe-Seyler, 1985. 366, 509-514.

276. F. Jilek, H. Hörmann. Fibronectin (Cold-Insoluble Globulin), VI. Influence of Heparin and Hyaluronic Acid on the Binding of Native Collagen. Hoppe-Seyler's Zeitschrift für physiologische Chemie, 1979. 360, 597-604.

277. D.C. Hocking, R.K. Smith, P.J. McKeown-Longo. A novel role for the integrinbinding III-10 module in fibronectin matrix assembly. The Journal of cell biology, 1996. 133, 431-444.

278. A. Morla, Z. Zhang, E. Ruoslahti. Superfibronectin is a functionally distinct form of fibronectin. Nature, 1994. 367, 193-196.

279. T. Volberg, J. Ulmer, J. Spatz, B. Geiger. Chemical and Mechanical Micro-Diversity of the Extracellular Matrix. K. Garikipati,E.M. Arruda, Editor. 2010, Springer Netherlands: $69-79$.

280. J. Ulmer, B. Geiger, J.P. Spatz. Force-induced fibronectin fibrillogenesis in vitro. Soft Matter, 2008. 4, 1998-2007.

281. G. Baneyx, V. Vogel. Self-assembly of fibronectin into fibrillar networks underneath dipalmitoyl phosphatidylcholine monolayers: role of lipid matrix and tensile forces. Proceedings of the National Academy of Sciences of the United States of America, 1999. 96, 12518-12523.

282. C. Zhong, M. Chrzanowska-Wodnicka, J. Brown, A. Shaub, A.M. Belkin, K. Burridge. Rho-mediated contractility exposes a cryptic site in fibronectin and induces fibronectin matrix assembly. The Journal of cell biology, 1998. 141, 539551. 
283. B. Wòjciak-Stothard, M. Denyer, M. Mishra, R.A. Brown. Adhesion, orientation, and movement of cells cultured on ultrathin fibronectin fibers. In vitro cellular \& developmental biology. Animal, 1997. 33, 110-117.

284. S. Underwood, A. Afoke, R.A. Brown, A.J. MacLeod, P.a. Shamlou, P. Dunnill. Wet extrusion of fibronectin-fibrinogen cables for application in tissue engineering. Biotechnology and bioengineering, 2001. 73, 295-305.

285. E. Klotzsch, M.L. Smith, K.E. Kubow, S. Muntwyler, W.C. Little, F. Beyeler, D. Gourdon, B.J. Nelson, V. Vogel. Fibronectin forms the most extensible biological fibers displaying switchable force-exposed cryptic binding sites. Proceedings of the National Academy of Sciences of the United States of America, 2009. 106, 1826718272.

286. S.I. Harding, S. Underwood, R.A. Brown, P. Dunnill. Assessment of cell alignment by fibronectin multi-fibre cables capable of large scale production. Bioprocess Engineering, 2000. 22, 159-164.

287. O.S. Ejim, G.W. Blunn, R.A. Brown. Production of artificial-oriented mats and strands from plasma fibronectin: a morphological study. Biomaterials, 1993. 14, 743-748.

288. Z. Ahmed, R.A. Brown. Adhesion, alignment, and migration of cultured Schwann cells on ultrathin fibronectin fibres. Cell motility and the cytoskeleton, 1999. 42, 331343.

289. N. Pernodet, M. Rafailovich, J. Sokolov, D. Xu, N.-L. Yang, K. McLeod. Fibronectin fibrillogenesis on sulfonated polystyrene surfaces. Journal of biomedical materials research. Part A, 2003. 64, 684-692.

290. D. Pellenc, H. Berry, O. Gallet. Adsorption-induced fibronectin aggregation and fibrillogenesis. Journal of colloid and interface science, 2006. 298, 132-144.

291. V. Nelea, M.T. Kaartinen. Periodic beaded-filament assembly of fibronectin on negatively charged surface. Journal of structural biology, 2010. 170, 50-59.

292. A.W. Feinberg, K.K. Parker. Surface-Initiated Assembly of Protein Nanofabrics. Nano letters, 2010. 10, 2184-2191.

293. R.A. Brown, G.W. Blunn,O.S. Ejim. Preparation of orientated fibrous mats from fibronectin: composition and stability. Biomaterials, 1994. 15, 457-464.

294. T.A. Petrie, J.E. Raynor, D.W. Dumbauld, T.T. Lee, S. Jagtap, K.L. Templeman, D.M. Collard, A.J. García. Multivalent integrin-specific ligands enhance tissue healing and biomaterial integration. Science translational medicine, 2010. 2, 45ra60-45ra60. 
295. M.P. Lutolf, P.M. Gilbert, H.M. Blau. Designing materials to direct stem-cell fate. Nature, 2009. 462, 433-441.

296. B. Geiger, A. Bershadsky, R. Pankov, K.M. Yamada. Transmembrane extracellular matrix- cytoskeleton crosstalk. Nature reviews. Molecular cell biology, 2001. 2, 793-805.

297. Y. Mao, J.E. Schwarzbauer. Fibronectin fibrillogenesis, a cell-mediated matrix assembly process. Matrix biology, 2005. 24, 389-399.

298. J.E. Schwarzbauer. Identification of the fibronectin sequences required for assembly of a fibrillar matrix. The Journal of cell biology, 1991. 113, 1463-1473. 
2. Objectives 

The aim of this work is to understand the influence of different materials properties on fibronectin adsorption and cell adhesion, seeking to comprehend the effect of different physico-chemical parameters in order to engineer advanced biomaterials to trigger protein adsorption and cell response.

Fibronectin, $\mathrm{FN}$, is an extracellular matrix protein which plays an important role in mediation of cell adhesion onto material substrates. In this work, we will perform different studies by using fibronectin as interface protein, evaluating cell response after investigating the state of the adsorbed fibronectin layer. The concrete objectives of this work are:

1) Investigate the role of nanoscale topography on cell response; by assessing cell adhesion, and the subsequent processes of FN matrix reorganization and secretion.

2) Study the effect of minute variations in surface chemistry on fibronectin adsorption, cell adhesion, and cell differentiation.

3) Investigate the effect of vitronectin in fibronectin adsorption, as well as the role in cell adhesion and fibronectin matrix reorganization.

4) Analyze cell-mediated fibronectin remodeling at the nanoscale, in order to understand this cellular process at molecular level. 

3. Materials and Methods 

In this chapter the materials and the main experimental methods employed to develop this work are described. The specific experimental conditions employed in each study are detailed in the corresponding chapter.

\subsection{Materials preparation}

Samples were prepared by spin coating, which is a very widely used technique for making uniform thin polymer films. The polymer solution is deposited onto the center of a substrate and then spinning the substrate at high speed. Centripetal acceleration will cause the polymer solution to spread to the edge of the substrate leaving a thin film of polymer on the surface. During spinning at high velocity, the solvent is evaporated. Final film thickness and other properties will depend on the nature of the polymer (viscosity, drying rate, percent solids, surface tension, etc.), the substrate surface and the parameters chosen for the spin process (rotational speed, acceleration, spin time).

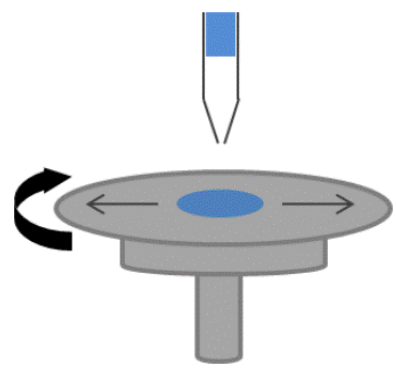

Figure 3.1 Spin casting process.

\subsubsection{PLLA/PS nanotopographies}

Two different sets of nanoscale topographies were prepared by polymer demixing techniques at high velocity as previously described [1-2]

For the first system of nanotopographies, PLLA (Cargill Dow) and PS (Sigma-Aldrich) were dissolved in chloroform (1wt-\%), common solvent for both polymers, at different ratios, 0/100, 10/90, 30/70, 50/50, 70/30, 90/10 and 100/0 
$\mathrm{w} / \mathrm{w}$. Spin-casting of the solutions was performed on $12 \mathrm{~mm}$ glass coverslips at $2000 \mathrm{rpm}$ during $30 \mathrm{~s}$, by making use of a spin-coater (Brewer Science).

The second set of PLLA/PS nanotopographies was prepared by dissolving both polymers at fixed polymer composition 50/50 w/w and different total polymer concentration $(0.5,1$, and $1.5 \%)$. Spin casting of the solutions was performed on $12 \mathrm{~mm}$ glass coverslips at $4000 \mathrm{rpm}$ for $30 \mathrm{~s}$. Pure PLLA was also spin-casted from a $2 \%$ solution with similar conditions (2000 rpm for $30 \mathrm{~s}$ ).

Samples were dried in vacuo at room temperature before further characterization.

\subsubsection{Acrylic polymers}

\section{$\underline{\text { Polymerization }}$}

Polymer sheets were obtained by radical polymerization of a solution of the corresponding vinyl monomer of alkyl acrylate, i.e. methyl (MA), ethyl (EA) and butyl (BA) (Sigma-Aldrich) using benzoin (98\% pure, Scharlau) as a photoinitiator of the reaction (a free radicals initiator). The polymerization was carried out up to limiting conversion in a UV oven for 12 hours. After polymerization, low molecular-mass substances (i.e. residual monomer) were extracted from the material by drying in vacuo in continuous extraction at $60^{\circ} \mathrm{C}$ for several days.

\section{Preparation of films}

Thin films were prepared by making use of a spin-coater. For that, each of the synthesized polymers was dissolved in toluene (Sigma-Aldrich). Spin casting was performed on $12 \mathrm{~mm}$ glass coverslips at $2000 \mathrm{rpm}$ for $30 \mathrm{~s}$. Samples were dried in vacuo at $60{ }^{\circ} \mathrm{C}$ for several hours to remove solvent traces before further characterization. 
In all cases, glass coverslips used as substrates to prepare the films were previously washed in ethanol, making use of an ultrasound device (Bandelin Sonorex Digitec), and then were rinsed with ethanol and dried with a nitrogen flow.

\subsection{Materials characterization}

\subsubsection{Water contact angle (WCA)}

Surface wettability was characterized by measuring the water contact angle, defined as the angle formed by a small drop of water in contact with a solid surface, which determines the hydrophilic character of the surface.

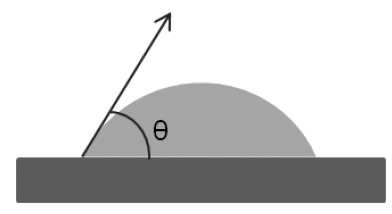

Figure 3.2 Measurement of the water contact angle.

A DataPhysics OCA 20 device was employed for measurements. The assays were performed in normal conditions of temperature and pressure. The volume of the drop was $10 \mu \mathrm{l}$ and the measurements were performed after $10 \mathrm{~s}$ of substrate-water contact and per triplicate on each substrate.

\subsubsection{Atomic force microscopy (AFM)}

Atomic force microscope was employed to characterize the surface roughness of the material substrates and determine the protein distribution on them.

The AFM can perform measurements in different operation modes and it is able to provide images with molecular level resolution, therefore it is a powerful tool to investigate biological molecules, as proteins adsorbed onto a material 
surface. In the tapping mode AFM (employed in this work), a flexible cantilever with a sharp tip at its end oscillates up and down near its resonance frequency with given amplitude. A laser beam that impact the cantilever is reflected and deflected in a regular pattern over a photodiode array, generating a sinusoidal electronic signal. When the tip comes into contact with the sample surface, a shift in the oscillation amplitude respective to that measured in the free oscillation, i.e. when the probe is far away from the surface, is produced. The vertical displacement (height) of the piezoelectric scanner, on which the sample is placed, needed to keep the set amplitude, provides information about the topography of the sample. Whereas the $x$ and $y$ movement of the scanner allows scan the surface.
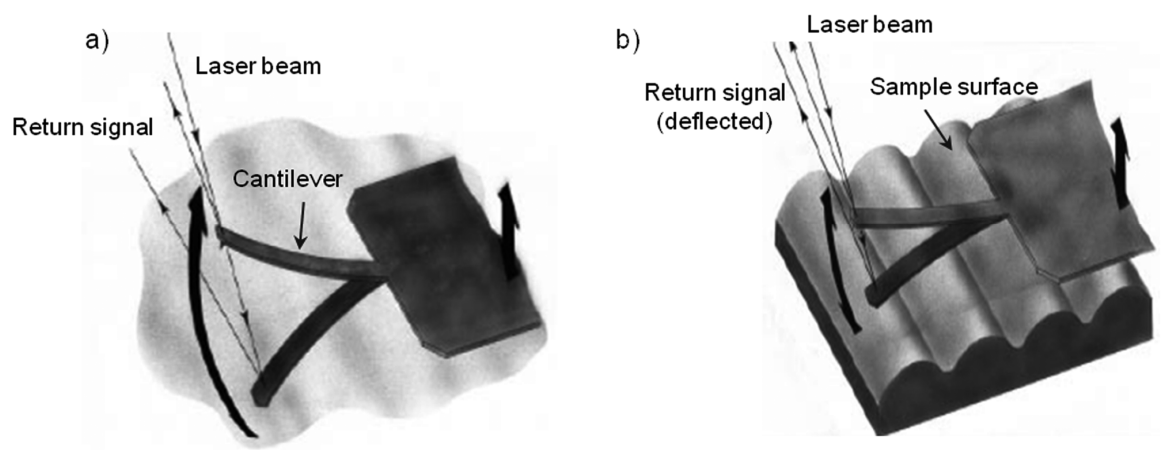

Figure 3.3 Tapping mode in AFM. a) Cantilever in free air, b) cantilever on sample surface. [Adapted from [3]]

The tapping force is an important factor to perform the measurements. According to the characteristics of the sample, it is possible to choose the more suitable tapping force, i.e. the force applied with the tip onto the surface. When the ratio between the amplitude in free oscillation, $A_{0}$, and the setpoint amplitude, $A_{s p}$, is close to 1 , a soft tapping is performed. On the contrary, a ratio around 0.5 is selected when a hard tapping is needed.

Moreover, the AFM in the tapping mode provides information about the viscoelastic properties of different parts of the sample thought phase changes in 
the tip oscillation. Therefore, it provides information about the morphology of the system. However, shifts in the oscillation phase may not only be produced for changes in the composition of different regions of the sample, but can also be induced by several geometric features in the material surface (i.e. edges, peaks, valleys, etc). When proteins are adsorbed on surfaces with roughness of the same order of magnitude as the protein, as frequently occurs in the case of biomaterials, the protein cannot be distinguished from the material topography. Because of that, the phase image in tapping mode AFM has been shown to be the experimental magnitude to be exploited to obtain significant information on protein conformation and distribution. On the other hand, AFM can perform these measurements under physiological conditions (in liquid environment), which allow investigating time-dependent and dynamic biological processes at the molecular scale.

In this work, AFM experiments were performed using a Multimode AFM equipped with NanoScope IIla controller (Digital Instruments-Veeco) operating in tapping mode. The Nanoscope 5.30r2 software version was used. Sicantilevers (Veeco, Manchester, UK) were used with force constant of $2.8 \mathrm{~N} / \mathrm{m}$ and resonance frequency of $75 \mathrm{kHz}$. The phase signal was set to zero at a frequency of $5-10 \%$ lower than the resonance one, as suggested by manufacturer. Drive amplitude was $600 \mathrm{mV}$ and the amplitude setpoint $\left(A_{s p}\right)$ was $1.8 \mathrm{~V}$. The ratio between the amplitude setpoint and the free amplitude $A_{\mathrm{sp}} / A_{0}$ was kept equal to 0.8 .

Samples were analyzed in the AFM, and height, phase and amplitude magnitudes were recorded simultaneously for each image. Areas of different sizes were scanned in several replicated samples of each material. All experiments were performed in a vibrations isolation system.

Besides, the AFM software was employed to determine the thickness of the films obtained by spin casting process. For that, the sample surface was scratched with a blade before being analyzed in the AFM. 
Since working in AFM in liquid conditions leads to some difficulties, mainly due to the low stability of the system, in this work, analysis of protein conformation and distribution, as well as cell morphology was performed in air. In preliminary studies, protein distribution under physiological conditions has been shown to be similar to those observed in air (see annex), thus results obtained in air can be considered as representative to those which would be obtained in liquid.

\subsubsection{Mechanical measurements}

The mechanical characterization of the materials was performed on a dynamic mechanical analysis device (DMA, Perkin Elmer) in the traction mode. The elastic modulus was recorded as a function of temperature; from $-50^{\circ} \mathrm{C}$ to $50^{\circ} \mathrm{C}$, using liquid nitrogen as refrigerant. Polymer bars of $5 \times 8 \times 1 \mathrm{~mm}$ of size were used.

\subsection{Protein adsorption}

\subsubsection{Protein distribution}

Protein was adsorbed on the different substrates by immersing the material films in several protein solutions of different concentration in PBS for $10 \mathrm{~min}$. After protein adsorption, samples were rinsed with PBS to eliminate the nonadsorbed protein. Remaining drops on the surface were dried by exposing the sample to a gently nitrogen flow for 2-3 min.

Protein distribution onto the materials was evaluated by AFM working in the tapping mode in air, immediately after protein adsorption. Height, phase and amplitude magnitudes were recorded simultaneously for each image. The protein distribution was mainly analyzed by the phase image, since frequently proteins cannot be distinguished from the material topography. 


\subsubsection{Protein quantification by radioactivity}

The amount of adsorbed fibronectin in equilibrium was quantified by radiolabelling the protein with ${ }^{125} \mathrm{I}$ using the lodogen method [4-5]. Briefly, an in water insoluble oxidant agent (1,3,4,6-tetrachloro-3a,6a-diphenyl glycoluril, (Sigma)) that allow the binding between the radioactive isotope and the FN molecule, was dissolved in dichloromethane (Sigma) at $1 \mathrm{mg} / \mathrm{ml}$ to obtain the iodo-gen solution in an eppendorf tube. The solvent was evaporated with a nitrogen flow and an iodo-gen layer was obtained in the walls of the eppendorf tube. Then, $10 \mu \mathrm{l}$ of FN (Sigma), $10 \mu \mathrm{l}$ of ${ }^{125}$ I (Perkin Elmer) and PBS $0.25 \mathrm{M}$ were added, and this solution was incubated for $20 \mathrm{~min}$. Thereafter, the ${ }^{125} \mathrm{I}-\mathrm{FN}$ solution was passed through Sephadex column G-25 M (PD-10 desalting column, Amersham Pharmacia Biotech) to remove the unbound ${ }^{125}$ and different fractions were collected (Figure 3.4).

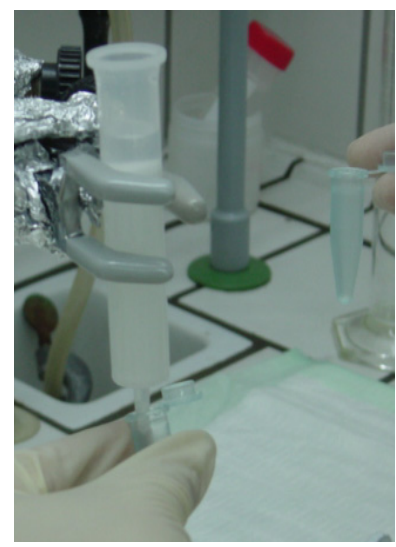

Figure 3.4 Sephadex column to remove the unbound ${ }^{125}$.

The yield of iodination in the different fractions was determined by precipitating the ${ }^{125}$ I-labeled FN with $20 \%$ trichloroacetic acid (TCA method). For that, the counts of the supernatant and the precipitated protein were measured. Only fractions with yield of iodination higher than $98 \%$ were used. 
The contribution of free ${ }^{125} \mathrm{I}$ to the total radioactivity found on the surfaces was estimated using unlabeled $\mathrm{FN}$ solutions at a concentration of $1 \mathrm{mg} / \mathrm{ml}$ and an amount of free ${ }^{125} \mathrm{I}$ ion equivalent to that present as ${ }^{125} \mathrm{I}$ ion in the labeled protein solutions.

In all studies in which radiolabeling methods are used it must be kept in mind that the behavior of the labeled protein may or may not reflect the behavior of unlabeled protein. To assess whether preferential adsorption of ${ }^{125}$ I-labeled FN occurred on the surfaces, a series of control experiments were performed in previous studies by varying the ratio of labeled to unlabeled $\mathrm{FN}$ (10-50\%). The final concentration of the $\mathrm{FN}$ solutions $(1 \mathrm{mg} / \mathrm{ml})$ was confirmed by the bicinchoninic acid (BCA) assay using a $B C A$ assay kit from Pierce and bovine serum albumin (BSA) as the standard [5].

Protein solutions for adsorption experiments were prepared by adding ${ }^{125} \mathrm{I}-$ $\mathrm{FN}$ to unlabeled FN solution to obtain a final activity of $10^{7} \mathrm{cpm} / \mathrm{mg}$.

FN adsorption tests were performed by placing the substrates $(5 \mathrm{~mm}$ diameter) in a 24-well tissue plate. Previously to the adsorption, samples were placed in Nal in PBS solution to inhibit the later free ${ }^{125}$ adsorption on the surfaces. A drop of $10 \mu \mathrm{l}$ of ${ }^{125} \mathrm{I}-\mathrm{FN}$ solution was added to each surface. Adsorption tests were carried out at $25^{\circ} \mathrm{C}$ for $60 \mathrm{~min}$. After this period the drop was removed from the surface and the surface was washed three times with PBS. The samples were transferred to radioimmunoassay tubes with PBS, and the surface activity was measured using an automatic gamma counter (model 1470 Wizard, from Wallac). In order to ensure that free ${ }^{125}$ I was removed of the surfaces, the samples were kept in PBS for $24 \mathrm{~h}$ and were transferred to other radioimmunoassay tubes to measure the surface activity again. All experiments were done in triplicate. The counts from each sample were averaged, and the surface concentration was calculated by the equation:

$$
[F N]\left(\mu g / m^{2}\right)=\frac{[\text { counts }(\text { cpm })] \cdot\left[[F N]_{\text {solution }}(\mu g / m L)\right]}{\left[A_{\text {solution }}(c p m / m L)\right] \cdot\left[S A\left(m^{2}\right)\right]} \quad \text { Equation } 2.1
$$


where the counts measure the radioactivity of the samples, $[\mathrm{FN}]_{\text {solution }}$ is the FN concentration in solution, $A_{\text {solution }}$ is the specific activity of the $F N$ solution, and $\mathrm{SA}$ is the surface area expressed as the area occupied by the drop during adsorption tests, measured by contact angle software.

After FN adsorption, samples were immersed in fresh unlabeled FN solutions $(20 \mu \mathrm{g} / \mathrm{ml})$ for $24 \mathrm{~h}$. Then, the surfaces were washed three times with PBS and the residual activity was measured in order to quantify the fraction of molecules that remains adsorbed on the different surfaces.

\subsubsection{Protein quantification by Western Blot}

The amount of adsorbed fibronectin was also quantified by measuring the remaining protein in the supernatant, i.e. the amount of protein that remained in solution without adsorbing on the material surface, as explained previously [6]. Different aliquots of non-adsorbed protein were subjected to $5 \%$-SDS polyacrylamide gel electrophoresis (PAGE), using Laemmli buffer $2 x$ and denaturing standard conditions. A prestained marker (Fermentas) was used to control the electrophoresis time. Afterwards, proteins were transferred to a positively charged polyvinylidene difluoride nylon membrane (GE Healthcare) using a semidry transfer cell system (Biorad), and blocked by immersion in $5 \%$ skimmed milk in PBS for $1 \mathrm{~h}$ at room temperature. The blot was incubated with anti-human fibronectin polyclonal antibody (developed in rabbit, Sigma) (1:500) in PBS containing $0.1 \%$ TWEEN 20 and $2 \%$ skimmed milk for $1 \mathrm{~h}$ at room temperature and washed three times (10 $\mathrm{min}$ for each wash) with PBS containing $0.1 \%$ TWEEN 20 . The blot was subsequently incubated in horseradish peroxidase-conjugated donkey anti-rabbit immunoglobulin G (GE Healthcare) diluted 1:20000 in PBS containing TWEEN 20 and $2 \%$ milk ( $1 \mathrm{~h}$ at room temperature). The enhanced chemiluminescence detection system (GE Healthcare) was used according to the manufacturer's instructions prior to exposing the blot to an X-ray film for $5 \mathrm{~min}$. The X-ray film, excited by the chemiluminescence emitted by the blot, was revealed to visualize the blot which 
was subjected to image analysis. Several known amounts of FN were also charged in the gel to obtain the relationship between the protein concentration and the band intensity, which was employed to quantify the amount of FN adsorbed on the substrates.

\subsection{Cell culture}

\subsubsection{Cell lines}

Prior to seeding on substrates, cells were maintained in DMEM medium supplemented with $1 \%$ penicillin-streptomycin and $10 \%$ fetal bovine serum (for MC3T3-E1 cells) or calf serum (for NiH3T3 cells), and passaged twice a week using standard techniques.

Sample disks (12 $\mathrm{mm}$ diameter) placed in a 24-well tissue culture plate were sterilized in UV and coated with FN. After coating time, samples were washed with PBS to remove the non-adsorbed protein. Cells were trypsinized and the cell pellet was resuspended in DMEM in serum-free conditions and then, cells were placed onto each substrate and were maintained at $37^{\circ} \mathrm{C}$ in a humidified atmosphere under $5 \% \mathrm{CO}_{2}$ for different culture times. Each experiment was performed in triplicate.

\subsubsection{Mesenchymal stem cells (MSCs)}

Human bone marrow stromal cells were obtained from hematologically normal patients undergoing routine hip-replacement surgery as described previously with full ethical approval and patient consent [7]. Skeletal/mesenchymal stem cell populations were enriched from the bone marrow stromal cell population with Stro-1 selection using magnetic activated cells sorting (MACS) as previously detailed [8]. Stro-1 has been used as a stringent marker for enhancing the most primitive multipotent population of the bone marrow [9-12]. Thus, these cells can be used at very low passage 
preventing phenotypical drift due to prolonged culture/excessive passaging.

Prior to seeding on FN-coated substrates, STRO-1+ cells were cultured in $75 \mathrm{~cm}^{2}$ tissue culture flasks and cells were maintained in basal medium (aMEM supplemented with $10 \%$ foetal bovine serum and $2 \%$ antibiotics) at $37^{\circ} \mathrm{C}$. All cells used in differentiation studies were from passage 3 or lower.

Sample disks (12 $\mathrm{mm}$ diameter) previously sterilized in UV and placed in a 24-well tissue culture plate were hydrated with PBS and coated with FN 20 $\mu \mathrm{g} / \mathrm{ml}$ ( $1 \mathrm{~h}$ at room temperature). Then, $1 \times 10^{4}$ cells were placed onto each substrate and the experiments were carried out in aMEM medium in serum-free conditions at $37^{\circ} \mathrm{C}$ in a humidified atmosphere under $5 \% \mathrm{CO}_{2}$ for $2 \mathrm{~h}$. After that, the medium was replaced by aMEM medium with $10 \% \mathrm{FBS}$, in order to provide the necessary nutrients during the incubation time, and the substrates were incubated at $37^{\circ} \mathrm{C}$ for different times: 3 days for cell adhesion, 1 day to detect the phosphorylation of Runx2, and 21 days for osteocalcin (OCN) and osteopontin (OPN) expression. The medium was replaced after one culture day in all experiments, and it was changed twice weekly in experiments of 21 days. Each experiment was performed in triplicate.

\subsection{Immunofluorescence assays}

\subsubsection{Cell adhesion}

To characterize the cell adhesion to the substrates, after culture time, cells were washed in Dulbecco's phosphate buffered saline (DPBS, Invitrogen) and fixed in Formalin solution $10 \%$ (Sigma) at $4{ }^{\circ} \mathrm{C}$ for 30 min. Afterwards, the samples were rinsed with DPBS three times and a permeabilising buffer $(10.3 \mathrm{~g}$ sucrose, $0.292 \mathrm{~g} \mathrm{NaCl}, 0.06 \mathrm{~g} \mathrm{MgCl}_{2}, 0.476 \mathrm{~g}$ Hepes buffer, $0.5 \mathrm{ml}$ Triton $\mathrm{X}$, in $100 \mathrm{ml}$ water, $\mathrm{pH}$ 7.2) was added at room temperature for $5 \mathrm{~min}$. In order to reduce the background signal, the samples were then incubated in $1 \%$ BSA/DPBS at room temperature for $30 \mathrm{~min}$. Then, samples were incubated in 
monoclonal mouse antibody against vinculin (1:400 in 1\% BSA/DPBS; Sigma) at room temperature for $1 \mathrm{~h}$. The samples were rinsed in 0.5\% Tween 20/DPBS three times for $5 \mathrm{~min}$ each. Alexa fluor 633-conjugated rabbit anti-mouse secondary antibody (1:200 in 1\% BSA/DPBS; Invitrogen) was then added at room temperature for $1 \mathrm{~h}$. Simultaneously, BODIPY FL phallacidin was added for the duration of this incubation (1:40 in 1\% BSA/PBS; Invitrogen). Finally, samples were washed in $0.5 \%$ Tween 20/DPBS three times before mounted in Vectashield containing DAPI (Vector Laboratories, Peterborough, UK). A fluorescence microscope was used for cellular imaging.

\subsubsection{Fibronectin reorganization and secretion}

The ability of cells to reorganize adsorbed FN (i.e. early matrix) was monitored after coating all samples with a $20 \mu \mathrm{g} / \mathrm{ml} \mathrm{FN}$ solution and rinsing with PBS twice before seeding cells in serum containing medium. To assess the ability of cells to secrete and deposit $\mathrm{FN}$ into the extracellular matrix fibrils (i.e. late matrix) cells were cultured on the substrates for different culture times in serum containing medium. After fixing cells, the evolution of FN in the ECM was followed by immunofluorescence as explained in section 2.5.1. A polyclonal rabbit anti-FN antibody (1:400 in 1\% BSA/DPBS, Sigma) and a goat anti-rabbit Cy3-conjugated secondary antibody (1:200 in 1\% BSA/DPBS, Jackson Research) were used.

\subsubsection{Collagen I expression}

To assess the ability of MC3T3 osteoblastic-like cells to express collagen I, after culture time cells were washed in Dulbecco's phosphate buffered saline (DPBS, Invitrogen) and fixed in formaldehyde solution 3.7\% (Sigma) at room temperature for $15 \mathrm{~min}$. Afterwards, collagen I expression was detected by immunofluorescence as explained in section 2.5.1. A monoclonal mouse antibody against collagen I (1:400 in 1\% BSA/DPBS; Sigma) and a Cy3- 
conjugated anti-mouse secondary antibody (1:200 in 1\% BSA/DPBS; Invitrogen) were used.

\subsubsection{Matrix Metalloproteinase-2 expression (MMP2)}

The expression of matrix metalloproteinase- 2 by MC3T3 cells on the substrates was evaluated by inmunofluorescence as explained in section 2.5.1. After different culture times, cells were washed in Dulbecco's phosphate buffered saline (DPBS, Invitrogen) and fixed in Formalin solution 10\% (Sigma) at $4{ }^{\circ} \mathrm{C}$ for $30 \mathrm{~min}$. A polyclonal rabbit antibody against MMP2 $(2 \mu \mathrm{g} / \mathrm{ml}$ in $1 \%$ BSA/DPBS; Sigma) and a Cy3-conjugated anti-rabbit secondary antibody (1:200 in 1\% BSA/DPBS; Invitrogen) were used.

\subsubsection{Mesenchymal stem cell differentiation}

The MSCs adhesion and differentiation on the different substrates was investigated. The cell differentiation was assessed by several osteogenic markers. After different culture times, MSCs were washed in phosphate buffered saline (PBS) and fixed with $4 \%$ formaldehyde (Fisher) with $2 \%$ sucrose in phosphate-buffered saline (PBS), at $37^{\circ} \mathrm{C}$ for 15 minutes. Afterwards, the samples were rinsed with PBS and a permeabilising buffer (10.3 g sucrose, $0.292 \mathrm{~g} \mathrm{NaCl}, 0.06 \mathrm{~g} \mathrm{MgCl} 2,0.476 \mathrm{~g}$ Hepes buffer, $0.5 \mathrm{ml}$ Triton $\mathrm{X}$, in $100 \mathrm{ml}$ PBS, pH 7.2) was added at $4{ }^{\circ} \mathrm{C}$ for 5 minutes. The samples were saturated then with $1 \% \mathrm{BSA} / \mathrm{DPBS}$ at $37^{\circ} \mathrm{C}$ for 5 minutes. Subsequently they were incubated a $37^{\circ} \mathrm{C}$ for $1 \mathrm{~h}$ with primary antibody against vinculin (monoclonal mouse antibody, Sigma, 1:150) and with rhodamine-conjugated phalloidin (Invitrogen, 1:50) to stain actin; or phosphoRunx2 (rabbit polyclonal, Abgent, $1: 100$ ), or OPN (mouse monoclonal, Autogen Bioclear, 1:50), or OCN (mouse monoclonal, Autogen Bioclear, 1:50), all of them dissolved in 1\% BSA in PBS. After three washes with PBS/0.5\% Tween 20, the appropriate biotinylated antimouse or anti-rabbit secondary antibody (Vector Laboratories, 1:50) was incubated for 60 minutes at $37^{\circ} \mathrm{C}$, followed by fluorescein streptavidin tertiary 
label (Vector Laboratories, 1:50) for 30 minutes at $4{ }^{\circ} \mathrm{C}$. Finally the samples were rinsed in PBS three times before mounted in Vectashield containing DAPI staining (Vector Laboratories). Secondary and tertiary antibody controls were performed for these cells. A fluorescence microscope was used for imaging.

\subsection{Cell morphology by AFM}

The AFM was also employed to assess the cell morphology and the protein distribution onto the substrate, at the nanoscale, after cell seeding. For that, after different culture times, cells were washed in Dulbecco's phosphate buffered saline (DPBS, Invitrogen) and fixed in Formalin solution 10\% (Sigma) at $4{ }^{\circ} \mathrm{C}$ for $30 \mathrm{~min}$. Remaining drops of DPBS on the sample surface were gently dried by exposing the sample to a nitrogen flow for 2-3 $\mathrm{min}$.

Cell morphology and the cell-mediated protein distribution were evaluated by AFM working in the tapping mode in air environment, immediately after sample preparation. Height, phase and amplitude magnitudes were recorded for each image.

\subsection{Gelatin zymography}

To detect actives and pro-matrix metalloproteinases (gelatinases MMP2 and 9) secreted by cells, MC3T3 cells were cultures on each material for different culture times in serum-free conditions. After culture time, the supernatants were subjected to $10 \%$-SDS polyacrylamide gel electrophoresis (PAGE) containing $0.1 \%$ gelatin (Biorad), using a loading buffer 2x $(62.5 \mathrm{mM}$ Tris- $\mathrm{HCl} \mathrm{pH} 6.8,25 \%$ glycerol, $4 \%$ SDS, $0.01 \%$ bromophenol blue) and denaturing standard conditions. A prestained marker was employed to control the electrophoresis time. Afterwards, gelatin gel was incubated in renaturation buffer $(2.5 \%$ Triton $\mathrm{X}-100 / \mathrm{H}_{2} \mathrm{O}$ ) at room temperature for $30 \mathrm{~min}$ to remove the SDS and thus, the proteinase activity was retrieved. Then, gel was incubated in a development 
buffer (50mM base Tris, $200 \mathrm{mM} \mathrm{NaCl}, 5 \mathrm{mM}$ anhydrous $\mathrm{CaCl}_{2}, 0.02 \% 30 \%$ brij-35) overnight at $37^{\circ} \mathrm{C}$. The enzymatic activity was revealed by staining the gel at room temperature with a solution containing $0.5 \%$ Coomassie $(40 \%$ methanol, $10 \%$ acetic acid, $0.5 \%$ Coomassie R-250) and, subsequently, a destaining solution ( $40 \%$ methanol, $10 \%$ acetic acid) was added at room temperature to detect the bands. The bands were visualized with a Molecular Imager Gel Doc XR+ transilluminator (Imaging System, BioRad). The experiments were performed in duplicate.

\subsection{Live/Dead viability assay}

Cells were incubated for different culture times on FN-coated substrates in serum-free conditions. Each experiment was performed in triplicate. Then, cells were incubated for 15 min with $300 \mu \mathrm{l}$ of combined Live/Dead assay reagents, using the concentrations recommended by the manufacturer: $2 \mu \mathrm{m}$ calcein $\mathrm{AM}$ and $4 \mu \mathrm{M}$ Ethidium homodimer-1 (EthD-1, Molecular Probes, Inc, Eugene, OR). The nonfluorescent cell-permeant calcein AM converts to the fluorescent calcein in live cells, due to the esterase activity of these cells. The polyanionic dye calcein is retained within live cells, producing an intense uniform green fluorescence. On the other hand, the EthD-1 is able to enter cells with damaged membranes, whereas it is excluded by the intact plasma membrane of live cells. When EthD-1 enters dead cells, binds to the nucleic acids and undergoes an enhancement of fluorescence producing a bright red. All the labelled cells were visualized under a fluorescence microscope. Viable green fluorescent cells and dead red fluorescent cells were counted in ten different fields, and the percent of dead cells was calculated. The results were averaged. 


\subsection{Image analysis}

All image processing and analysis was done using an in house software developed under MATLAB R2008a and R2009a (The MathWorks, Inc., Natick, MA, USA).

\subsubsection{FN distribution on the PLLA/PS nanotopographies}

For calculating the distribution of $\mathrm{FN}$ between valleys and pits, the valleys and the pits were firstly delineated. For this, the height AFM image was grayscaled and equalized, providing an output grayscale image with its intensity values evenly distributed throughout the intensity range, and then a median filtering was applied to the resulting image to reduce noise background. This new image was then binarized through Otsu's method [13], which chooses the threshold that minimizes the intraclass variance of the thresholded black and white pixels, providing a binary image with the valleys and the pits perfectly segmented. The contour of the pits was then easily extracted and applied, in a second step, to the amplitude and phase AFM images.

FN was detected from the amplitude and phase AFM images. It was afterwards associated to the valleys or to the pits based on the contour between both previously detected using the height AFM images, and the results were averaged. For this procedure, several steps were followed: (i) both images were firstly grayscaled, equalized and a median filtering was applied to the resulting images for a background noise reduction. The histogram of both images was then automatically stretched for a fair detection of the protein. The images were then size-filtered to avoid the detection of any too small region not corresponding to proteins. Once the protein was correctly detected, it was associated to a valley or to a pit based on the contour previously detected from the height AFM image. The resulting protein distribution was averaged between the amplitude and the phase images. 


\subsubsection{Western blot bands}

All the western bands were digitized using the same scanner (Epson Stylus Photo RX500, Seiko Epson Corpo., Nagano, Japan) and the same scan parameters: 8 bits gray scale image and $300 \mathrm{dpi}$. The digitized images were binarized using the Otsu method, which chooses the threshold that minimizes the intraclass variance of the thresholded black and white pixels, in order to create a mask that automatically selected the edge of each western blot band [13]. This mask was applied to a negative version of the original scanned picture providing a resulting image which contained only the western bands. The last step of the process consisted of adding all the pixels that conformed each band correctly weighted by their intensity level.

\subsubsection{Size of the focal plaques}

The size distribution of the focal plaques was determined through a severalstep image analysis including a contour delineation of the cell. For a perfect segmentation of the cell, (i) images showing the actin cytoskelton were grayscaled and equalized. (ii) The cell was then detected (segmented): since the cytoskeleton differed greatly in contrast from the background image, a gradient-magnitude method (Sobel) [14-16] was applied to the image and once the gradient image was calculated, a binary mask was created containing the segmented cytoskeleton. (iii) Compared to the original image, the binary gradient mask showed gaps in the lines surrounding the cell (the outline of the object of interest was not completely delineated). These linear gaps disappeared when the Sobel image was dilated using linear structuring elements (a vertical structuring element followed by a horizontal one), obtaining a clear and perfect contour detection of the cell. Once the cell was perfectly segmented, the obtained binary mask was then applied to the image obtained in the red channel for vinculin. This permitted to focus the attention on the cell and the focal adhesions, as other any object in the image was virtually erased. This new image was then binarized through Otsu's method [13] and size-filtered to 
avoid any extra small particles in the image that did not represent focal plaques which sizes wanted to be determined. Once the sizes of the focal contacts were determined, a size distribution was easily obtained.

\subsubsection{Secreted matrix-associated proteins}

To quantify the level of differentiation markers from fluorescence images (osteocalcin, osteopontin, phosphoRunx2), images were firstly equalized, providing an output grayscale image with its intensity values evenly distributed throughout the intensity range. Afterwards, they were segmented into 5 different classes by means of Otsu's multiple thresholding method [13]. Each class was then size-filtered using an opening morphological operator to eliminate remaining isolated pixels and the existing gaps were filled using an erosion morphological operator followed by a dilation one, using both a diamond structuring element of size 3 . The calculus of the intensity and the area covered by the 3 most brightest classes of the 5 different ones into which the image was segmented previously was then easily performed.

\subsection{Statistics}

All experiments were performed at least three times, in triplicate, unless otherwise noted. Data are reported as mean \pm standard error. Results were analyzed by one-way ANOVA using SYSTAT 8.0 (SPSS). If treatment level differences were determined to be significant, pair-wise comparisons were performed using a Tukey post hoc test. A 95\% confidence level was considered significant. 


\subsection{References}

1. J.Y. Lim, J.C. Hansen, C.A. Siedlecki, R.W. Hengstebeck, J. Cheng, N. Winograd H.J. Donahue. Osteoblast Adhesion on Poly(I-lactic Acid)/Polystyrene Demixed Thin Film Blends: Effect of Nanotopography, Surface Chemistry, and Wettability. Biomacromolecules, 2005. 6, 3319-3327.

2. J.Y. Lim, A.D. Dreiss, Z. Zhou, J.C. Hansen, C.A. Siedlecki, R.W. Hengstebeck, J. Cheng, N. Winograd, H.J. Donahue. The regulation of integrin-mediated osteoblast focal adhesion and focal adhesion kinase expression by nanoscale topography. Biomaterials, 2007. 28, 1787-1797.

3. Veeco Metrology Group, Multimode SPM Instruction Manual. Digital Instruments.

4. I. Amersham. lodine-125. 1993, Little Chalfont, Buckinghamshire, U.K.

5. R.S. Sousa, M.M. Brás, P. Moradas-Ferreira, M.A. Barbosa. Dynamics of Fibronectin Adsorption on TiO2 Surfaces. - Langmuir, 2007. 23, 7046-7054.

6. P. Rico, J.C. Rodríguez Hernández, D. Moratal, G. Altankov, M. Monleón Pradas, M. Salmerón-Sánchez. Substrate-Induced Assembly of Fibronectin into Networks: Influence of Surface Chemistry and Effect on Osteoblast Adhesion. Tissue Engineering: Part A, 2009. 15, 3271-3281.

7. X.B. Yang, H.I. Roach, N.M.P. Clarke, S.M. Howdle, R. Quirk, K.M. Shakesheff, R.O.C. Oreffo. Human osteoprogenitor growth and differentiation on synthetic biodegradable structures after surface modification. Bone, 2001. 29, 523-531.

8. D. Howard, K. Partridge, X. Yang, N.M.P. Clarke, Y. Okubo, K. Bessho, S.M. Howdle, K.M. Shakesheff, R.O.C. Oreffo. Immunoselection and adenoviral genetic modulation of human osteoprogenitors: in vivo bone formation on PLA scaffold. Biochemical and biophysical research communications, 2002. 299, 208-215.

9. S.-H. Mirmalek-Sani, R.S. Tare, S.M. Morgan, H.I. Roach, D.I. Wilson, N.A. Hanley, R.O.C. Oreffo. Characterization and Multipotentiality of Human Fetal FemurDerived Cells: Implications for Skeletal Tissue Regeneration. Stem cells, 2006. 24, 1042-1053.

10. P.J. Simmons, B. Torok-Storb. Identification of stromal cell precursors in human bone marrow by a novel monoclonal antibody, STRO-1. Blood, 1991. 78, 55-62.

11. J.T. Triffitt, C.J. Joyner, R.O.C. Oreffo, A.S. Virdi. Osteogenesis: bone development from primitive progenitors. Biochemical Society Transactions, 1998. 26, 21-27.

12. X. Yang, R.S. Tare, K.A. Partridge, H.I. Roach, N.M.P. Clarke, S.M. Howdle, K.M. Shakesheff, R.O.C. Oreffo. Induction of Human Osteoprogenitor Chemotaxis, 
Proliferation, Differentiation, and Bone Formation by Osteoblast Stimulating Factor1/Pleiotrophin: Osteoconductive Biomimetic Scaffolds for Tissue Engineering. Journal of Bone and Mineral Research, 2003. 18, 47-57.

13. N. Otsu. A Threshold Selection Method from Gray-Level Histograms. IEEE Transactions on Systems, Man, and Cybernetics, 1979. 9, 62-66.

14. R.C. González, R.E. Woods, S.L. Eddins. Digital Image Processing Using MATLAB. 2003, Prentice-Hall, Upper Saddler River, NJ.

15. R.C. González, R.E. Woods. Digital Imaging Processing. 2007, Prentice-Hall, Upper Saddle River, NJ.

16. T. Mathworks. MATLAB Image Processing Toolbox User's Guide. 2006, Natick, MA. The MathWorks, Inc. 


\section{Effect of nanoscale topography on fibronectin adsorption and cell response}

\section{Summary}

In this chapter the effect of nanoscale topography on fibronectin adsorption and cell behavior is investigated. PLLA/PS nanotopographies with nanopits of different sizes were developed, and their influence on fibronectin adsorption (distribution and surface density) was analyzed. The biological activity of fibronectin on the nanostructures, determined by AFM and radiolabelling with ${ }^{125}$ I, was correlated with the initial cell adhesion of MC3T3 osteoblast-like cells and the cell-mediated FN matrix organization along the time. Nanotopographies with higher deep pits (29 and $45 \mathrm{~nm}$ ), where less amount of FN was adsorbed and focal adhesion plaques were more developed, the adsorbed FN layer was more reorganized, which resulted in higher production and organization of new FN matrix.

*Results presented in this chapter have been partially published in: PérezGarnes M, González-García C, Moratal D, Rico P, Salmerón-Sánchez M. Int J Artif Organs, 2011, 34, 1, 54-63; and González-García C, Sousa S.R, Moratal $D$, Rico $P$, Salmerón-Sánchez M. Colloids and Surfaces B: Biointerfaces, 2010, 77, 181-190. 



\subsection{Introduction}

Even if the cell-material interaction is not a direct one, but it is mediated by ECM proteins previously adsorbed on the substrate's surface, it is said that cells response to three different kind of surface parameters: chemical, topographical and mechanical [1]. Surface topography is a key parameter that is able to modify cell response independently of the chemical composition of the substrate. Even though sometimes topography is only a manifestation of material chemistry, many times it can be modulated in an independent way. The effect of topography on cell adhesion has been widely studied. Micro and nanopatterned surfaces have been prepared for a better understanding of the cell response to topographic features, mainly in what cell adhesion is concerned. Anisotropic surfaces prepared by lithographic and microfabrication techniques can induce cell reorientation following microgrooves, the so-called contact guidance phenomenon [2-3]; and the scale of anisotropic topography plays an important role in deciding cell alignment [4]. Different techniques have been used to produce controlled isotropic topographies at different scales which include photolithography, electron beam lithography, colloidal lithography, and polymer demixing techniques during a high-speed spin-casting process [5-6] which allows obtaining nanotopographic motifs in a broad range (from 9 to 100 $\mathrm{nm})$. However, the effect of nanotopography on cell response remains an open question. It seems that the interval $10-30 \mathrm{~nm}$ gives rise to better adhesion and higher stimulation of intracellular signalling than going up to $100 \mathrm{~nm}$ [7-9]. Cell differentiation and gene expression are also influenced by surface topography [10-11].

The effect of surface nanotopography on cell behavior should be a consequence of different protein adsorption patterns. It has been suggested that nanotopography is able to enhance protein adsorption as compared to the same plane chemistry [12], although other claim little effect of surface nanoroughness on protein adsorption [13]. Different substrates have been 
prepared in the recent years aiming at investigating the role of surface nanotopography in the cell-material interaction, especially what cell adhesion is concerned. These works are mainly focused in investigating the effect of material properties on the biological performance of the substrate and, only a few of them, investigate this effect by addressing first protein adsorption and conformation on the material surface and then by correlating this phenomenon with cell behavior.

\section{Polymer demixing by spin-casting}

Spin coating is a very widely used technique for making uniform thin polymer films, including single component and multi-component systems [14-15]. When several immiscible polymers are dissolved in a common solvent and a highspeed spin casting process is performed, a polymeric phase separation occurs due to the intrinsic immiscibility of the polymer blend. This phase separation is a complex non-equilibrium process, very sensitive to the characteristic of the solvent and the precise spinning conditions, and gives rise to different morphologies in the film surface. The thickness and surface morphology of the film depends on the exact spin-casting conditions, such as blend composition and concentration of the polymers [7, 16-18], solvent solubility and volatility [19$20]$, the speed of spin-coating [20], and the chemical nature of the substrate [19].

Phase separation can take place exclusively in the plane of the film, resulting in a laterally patterned film [16, 21-22], and can take place exclusively in the direction perpendicular to the plane of the film, resulting in a self-stratified film [23-24]. In the latter case, a preferential aggregation of one phase at the polymer-substrate interface and segregation of the other phase at the airpolymer interface may occur. The component with the lower surface free energy tends to be enriched at the surface in order to minimize the polymer-air surface tension [25]. Surface segregation can be promoted by substrate surface energy modification [26] and solvent evaporation control [19]. 
Recently, nanoscale topographies have been prepared by using poly $(\mathrm{L}-$ lactic) acid (PLLA) and polystyrene (PS) demixing techniques [7]. Randomly distributed nanoscale pits (14, 29 and $45 \mathrm{~nm}$ deep pits) were produced adjusting PLLA/PS at 50/50 (w/w) but varying the concentration of the spincasting solution. During the spin casting process the relatively low molecular weight PLLA segregates to the air-film interface, despite its relatively higher surface energy, to reduce the increase in entropy that would occur if high molecular weight PS is exposed to the surface [18]. PLLA migration to the top surface of the film during the spin casting process provides a system of nanotopographies which consists almost completely of PLLA on the material surface [7]; therefore the effect of nanotopography on cell response can be investigated after ruling out the influence of surface chemistry.

On these nanoscale topographies, it was suggested that cell attachment, cell spreading, integrin subunit expression, paxillin synthesis and FAK expression (and its phosphorylation) were enhanced on 14 and $29 \mathrm{~nm}$ deep pits compared to $45 \mathrm{~nm}$ deep pits or flat PLLA surfaces, which suggested that nanostructures provide physical signals that regulate cell function.

The present work further investigates the role of these nanostructured PLLA/PS nanotopographies on initial cell adhesion by paying special attention to the adsorbed protein layer as the biological interface between the synthetic substrate and the cell population. The amount of FN adsorbed on the different nanotopographies from solutions of different concentrations is quantified by radiolabelling the protein; the conformation and distribution $\mathrm{FN}$ on the synthetic surfaces is directly observed by atomic force microscopy (AFM). Moreover, initial cell adhesion on the different FN-coated nanostructured surfaces is investigated, as well the reorganization of the adsorbed FN layer (after $3 \mathrm{~h}$ ) and late matrix production as a function of time (after 1, 3 and 6 days). 


\subsection{Materials and methods}

\subsubsection{Preparation of nanotopographies}

Two different sets of nanoscale topographies were prepared by polymer demixing techniques at high velocity as previously described $[7,18]$.

PLLA (Cargill Dow) and PS (Sigma-Aldrich) were dissolved in chloroform (1wt-\%), common solvent for both polymers, at different ratios, 0/100, 10/90, $30 / 70,50 / 50,70 / 30,90 / 10$ and 100/0 w/w. Spin-casting of the solutions was performed on $12 \mathrm{~mm}$ glass coverslips at $2000 \mathrm{rpm}$ during $30 \mathrm{~s}$, by making use of a spin-coater (Brewer Science).

The second set of PLLA/PS nanotopographies was prepared by dissolving both polymers at fixed polymer composition 50/50 w/w and different total polymer concentration $(0.5,1$, and $1.5 \%)$. Spin casting of the solutions was performed on $12 \mathrm{~mm}$ glass coverslips at $4000 \mathrm{rpm}$ for $30 \mathrm{~s}$. Pure PLLA was also spin-casted from a $2 \%$ solution with similar conditions (2000 rpm for $30 \mathrm{~s}$ ).

Samples were dried in vacuo at room temperature before further characterization.

\subsubsection{Characterization of nanotopographies}

\section{Atomic force microscopy}

Atomic force microscope was employed to characterize the topography of the substrates and the protein distribution on their surfaces.

AFM experiments were performed using a Multimode AFM equipped with NanoScope Illa controller (Digital Instruments-Veeco) operating in tapping mode in air. The Nanoscope 5.30r2 software version was used. Si-cantilevers (Veeco, Manchester, UK) were used with force constant of $2.8 \mathrm{~N} / \mathrm{m}$ and resonance frequency of $75 \mathrm{kHz}$. The phase signal was set to zero at a 
frequency of $5-10 \%$ lower than the resonance one, as suggested by manufacturer. Drive amplitude was $600 \mathrm{mV}$ and the amplitude setpoint $\left(A_{\mathrm{sp}}\right)$ was $1.8 \mathrm{~V}$. The ratio between the amplitude setpoint and the free amplitude $A_{s p} / A_{0}$ was kept equal to 0.8 .

Height, phase and amplitude magnitudes were recorded simultaneously for each image. AFM software was employed to characterize the height of the nanofeatures.

\section{Water contact angle}

Surface wettability was characterized by measuring the water contact angle with a DataPhysics OCA 20 device. The volume of the drop was $10 \mu$ l. Measurements were performed per triplicate on each substrate.

\subsubsection{Protein adsorption}

The protein adsorption was characterized by the adsorbed surface density and its distribution on the different substrates.

\section{Protein distribution}

Fibronectin from human plasma (Sigma) was adsorbed on the different substrates by immersing the material disks in several $\mathrm{FN}$ solutions at concentrations of $2,5,10$ and $20 \mu \mathrm{g} / \mathrm{ml}$ in physiological solution $(\mathrm{NaCl} 0.9 \%)$ for $10 \mathrm{~min}$. After protein adsorption, samples were rinsed in the physiological solution to eliminate the non-adsorbed protein. Remaining drops on the surface were dried by exposing the sample to a nitrogen flow for 2-3 $\mathrm{min}$.

The protein distribution onto the nanotopographies was evaluated in the AFM, in the tapping mode in air, immediately after sample preparation. Height, phase and amplitude magnitudes were recorded simultaneously for each image. 


\section{Protein quantification by radioactivity}

The amount of adsorbed $\mathrm{FN}$ in equilibrium was quantified by radiolabelling the protein with ${ }^{125} \mathrm{I}$ using the lodogen Method (detailed in chapter of materials and methods) [27-28]. Thereafter ${ }^{125} \mathrm{I}-\mathrm{FN}$ was passed through Sephadex column G-25 M (PD-10 desalting column, Amersham Pharmacia Biotech) to remove unbound ${ }^{125} \mathrm{I}$. Only fractions with yield of iodination higher than $98 \%$ were used.

Protein solutions for adsorption experiments were prepared by adding ${ }^{125} \mathrm{I}-$ $\mathrm{FN}$ to unlabeled FN solution to obtain a final activity of $10^{7} \mathrm{cpm} / \mathrm{mg}$.

FN adsorption tests were performed by placing the substrates $(5 \mathrm{~mm}$ diameter) in a 24-well tissue plate. A drop of $10 \mu \mathrm{l}$ of $\left({ }^{125} \mathrm{I}-\mathrm{FN}\right)$ solution was added to each surface. Adsorption tests were carried out at $25^{\circ} \mathrm{C}$ for $60 \mathrm{~min}$ and different $\mathrm{FN}$ concentrations 2, 10 and $20 \mu \mathrm{g} / \mathrm{ml}$ were studied on each surface. After this period the surface was washed three times with PBS. The samples were transferred to radioimmunoassay tubes with PBS, and the surface activity was measured using an automatic gamma counter (model 1470 Wizard, from Wallac). In order to ensure that free ${ }^{125} \mathrm{I}$ is removed of the surfaces, the samples were kept in PBS for $24 \mathrm{~h}$ and were transferred to other radioimmunoassay tubes to measure the surface activity again. All experiments were done in triplicate. The counts from each sample were averaged, and the surface concentration was calculated by the equation:

$$
[F N]\left(\mu g / m^{2}\right)=\frac{[\operatorname{counts}(\mathrm{cpm})] \cdot\left[[F N]_{\text {solution }}(\mu \mathrm{g} / m L)\right]}{\left[A_{\text {solution }}(\mathrm{cpm} / \mathrm{mL})\right] \cdot\left[S A\left(\mathrm{~m}^{2}\right)\right]}(\text { Equation 4.1 })
$$

where the counts measure the radioactivity of the samples, $[\mathrm{FN}]_{\text {solution }}$ is the $\mathrm{FN}$ concentration in solution, $A_{\text {solution }}$ is the specific activity of the $F N$ solution, and $\mathrm{SA}$ is the surface area expressed as the area occupied by the drop during adsorption tests, measured by contact angle software. 
After FN adsorption, samples were immersed in fresh unlabeled FN solutions $(20 \mu \mathrm{g} / \mathrm{ml})$ for $24 \mathrm{~h}$. Then, the surfaces were washed three times with PBS and the residual activity was measured in order to quantify the fraction of molecules that remains adsorbed on the different surfaces.

\subsubsection{Cell culture}

MC3T3-E1 cells were obtained from the RIKEN CELL BANK (Japan). Prior to seeding on FN-coated substrates, cells were maintained in DMEM medium supplemented with $10 \%$ fetal bovine serum and $1 \%$ penicillin-streptomycin and passaged twice a week using standard techniques. Sample disks $(12 \mathrm{~mm}$ diameter) placed in a 24-well tissue culture plate were coated with FN $20 \mu \mathrm{g} / \mathrm{ml}$ $\left(12 \mathrm{~h}\right.$ at $\left.37^{\circ} \mathrm{C}\right)$. Then, $10^{3}$ cells were placed onto each substrate (cell density: 500 cells $/ \mathrm{cm}^{2}$ ) and were maintained at $37^{\circ} \mathrm{C}$ in a humidified atmosphere under $5 \% \mathrm{CO}_{2}$ for $3 \mathrm{~h}$, to analyze the initial cell adhesion and $\mathrm{FN}$ reorganization, and for 1,3 and 6 days to observe the FN matrix formation as a function of time. Each experiment was performed in triplicate.

\subsubsection{Cell adhesion}

After 3h of culture, MC3T3-E1 cells were washed in Dulbecco's phosphate buffered saline (DPBS, Invitrogen) and fixed in Formalin solution 10\% (Sigma) at $4{ }^{\circ} \mathrm{C}$ for $1 \mathrm{~h}$. Afterwards, the samples were rinsed with DPBS three times and a permeabilising buffer (10.3 g sucrose, $0.292 \mathrm{~g} \mathrm{NaCl}, 0.06 \mathrm{~g} \mathrm{MgCl}_{2}, 0.476 \mathrm{~g}$ Hepes buffer, $0.5 \mathrm{ml}$ Triton $\mathrm{X}$, in $100 \mathrm{ml}$ water, $\mathrm{pH}$ 7.2) was added at room temperature for $5 \mathrm{~min}$. Samples were blocked with $1 \%$ BSA/DPBS at room temperature for $30 \mathrm{~min}$ and were incubated in monoclonal mouse antibody against vinculin (1:400 in 1\% BSA/DPBS; Sigma) at room temperature for $1 \mathrm{~h}$. The samples were rinsed in 0.5\% Tween 20/DPBS three times for 5 min each. Alexa fluor 633-conjugated rabbit anti-mouse secondary antibody (1:200 in 1\% BSA/DPBS; Invitrogen) was then added at room temperature for $1 \mathrm{~h}$. Simultaneously, BODIPY FL phallacidin was added for the duration of this 
incubation (1:40 in 1\% BSA/PBS; Invitrogen). Finally, samples were washed in 0.5\% Tween 20/DPBS three times before mounted in Vectashield containing DAPI (Vector Laboratories, Peterborough, UK). A Leica DM6000B fluorescent microscope was used for cellular imaging.

\subsubsection{Fibronectin reorganization and secretion}

The ability of cells to reorganize adsorbed FN (i.e. early matrix) was monitored after coating all samples with a $20 \mu \mathrm{g} / \mathrm{ml} \mathrm{FN}$ solution and rinsing with PBS twice before seeding cells in serum containing medium. To assess the ability of cells to secrete and deposit FN into the extracellular matrix fibrils (i.e. late matrix) cells were cultured on the different substrates for $3 \mathrm{~h}, 1,3$ and 6 days in serum containing medium. The evolution of FN in the ECM was followed by immunofluorescence. At the end of incubation time, cells were washed in Dulbecco's phosphate buffered saline (DPBS, Invitrogen) and fixed in 10\% formalin solution (Sigma) at $4{ }^{\circ} \mathrm{C}$ for $1 \mathrm{~h}$. Samples were rinsed with DPBS and the permeabilization buffer was added at room temperature for $5 \mathrm{~min}$. Samples were incubated with a polyclonal rabbit anti-FN antibody (1:400, Sigma), dissolved in $1 \%$ BSA/DPBS for $1 \mathrm{~h}$, washed, and incubated with a goat antirabbit Cy3-conjugated secondary antibody for $1 \mathrm{~h}$ before washed and mounted with Vectashield containing DAPI. A Leica DM6000B fluorescence microscope was used.

\subsubsection{Image analysis}

All image processing and analysis was done using an in house software developed under MATLAB R2008a and R2009a (The MathWorks, Inc., Natick, MA, USA).

\section{Area covered by raised nanofeatures}

To determine the fraction of area covered by raised nanofeatures, valleys and the pits were delineated. For this, the height AFM image was grayscaled 
and equalized, providing an output grayscale image with its intensity values evenly distributed throughout the intensity range, and then a median filtering was applied to the resulting image to reduce noise background. This new image was then binarized through Otsu's method [29], which chooses the threshold that minimizes the intraclass variance of the thresholded black and white pixels, providing a binary image with the valleys and the pits perfectly segmented. The contour of the pits was then easily extracted and their area was determined.

\section{FN distribution on the PLLA/PS nanotopographies}

For calculating the distribution of FN between valleys and pits, the valleys and the pits were firstly delineated as above. The contour of the pits was then easily extracted and applied, in a second step, to the amplitude and phase AFM images.

FN was detected from the amplitude and phase AFM images. It was afterwards associated to the valleys or to the pits based on the contour between both previously detected using the height AFM images, and the results were averaged. For this procedure, several steps were followed: (i) both images were firstly grayscaled, equalized and a median filtering was applied to the resulting images for a background noise reduction. The histogram of both images was then automatically stretched for a fair detection of the protein. The images were then size-filtered to avoid the detection of any too small region not corresponding to proteins. Once the protein was correctly detected, it was associated to a valley or to a pit based on the contour previously detected from the height AFM image. The resulting protein distribution was averaged between the amplitude and the phase images.

\section{Size of the focal plaques}

The size distribution of the focal plaques was determined through a severalstep image analysis including a contour delineation of the cell. For a perfect segmentation of the cell, (i) images showing the actin cytoskeleton were 
grayscaled and equalized. (ii) The cell was then detected (segmented): since the cytoskeleton differed greatly in contrast from the background image, a gradient-magnitude method (Sobel) [30-32] was applied to the image and once the gradient image was calculated, a binary mask was created containing the segmented cytoskeleton. (iii) Compared to the original image, the binary gradient mask showed gaps in the lines surrounding the cell (the outline of the object of interest was not completely delineated). These linear gaps disappeared when the Sobel image was dilated using linear structuring elements (a vertical structuring element followed by a horizontal one), obtaining a clear and perfect contour detection of the cell. Once the cell was perfectly segmented, the obtained binary mask was then applied to the image obtained in the red channel for vinculin. This permitted to focus the attention on the cell and the focal adhesions, as other any object in the image was virtually erased. This new image was then binarized through Otsu's method [29] and size-filtered to avoid any extra small particles in the image that did not represent focal plaques which sizes wanted to be determined. Once the sizes of the focal contacts were determined, a size distribution was easily obtained.

\subsubsection{Statistics}

All experiments were performed at least three times, in triplicate, unless otherwise noted. Data are reported as mean \pm standard error. Results were analyzed by one-way ANOVA using SYSTAT 8.0 (SPSS). If treatment level differences were determined to be significant, pair-wise comparisons were performed using a Tukey post hoc test. A 95\% confidence level was considered significant. 


\subsection{Results and discussion}

\subsubsection{Nanoscale topographies}

\section{Different geometrical nanofeatures}

Figure 4.1 shows AFM height and amplitude images of PLLA/PS nanotopographies as obtained during polymer demixing in a high speed spincasting on glass coverslips at various ratios of the base components (PLLA/PS): 0/100, 10/90, 30/70, 50/50, 70/30, 90/10, 100/0, and fixed total polymer concentration (1 wt\%). Flat substrates are obtained for pure PS and PLLA, whereas nanotopographic motifs are found for every intermediate composition: interconnected pits for the substrates with PLLA content below $50 \%$ (included), and isolated islands above 50\% PLLA. Therefore, the materials surface consists of valleys and peaks with a characteristic geometric distribution (Figure 4.1). 

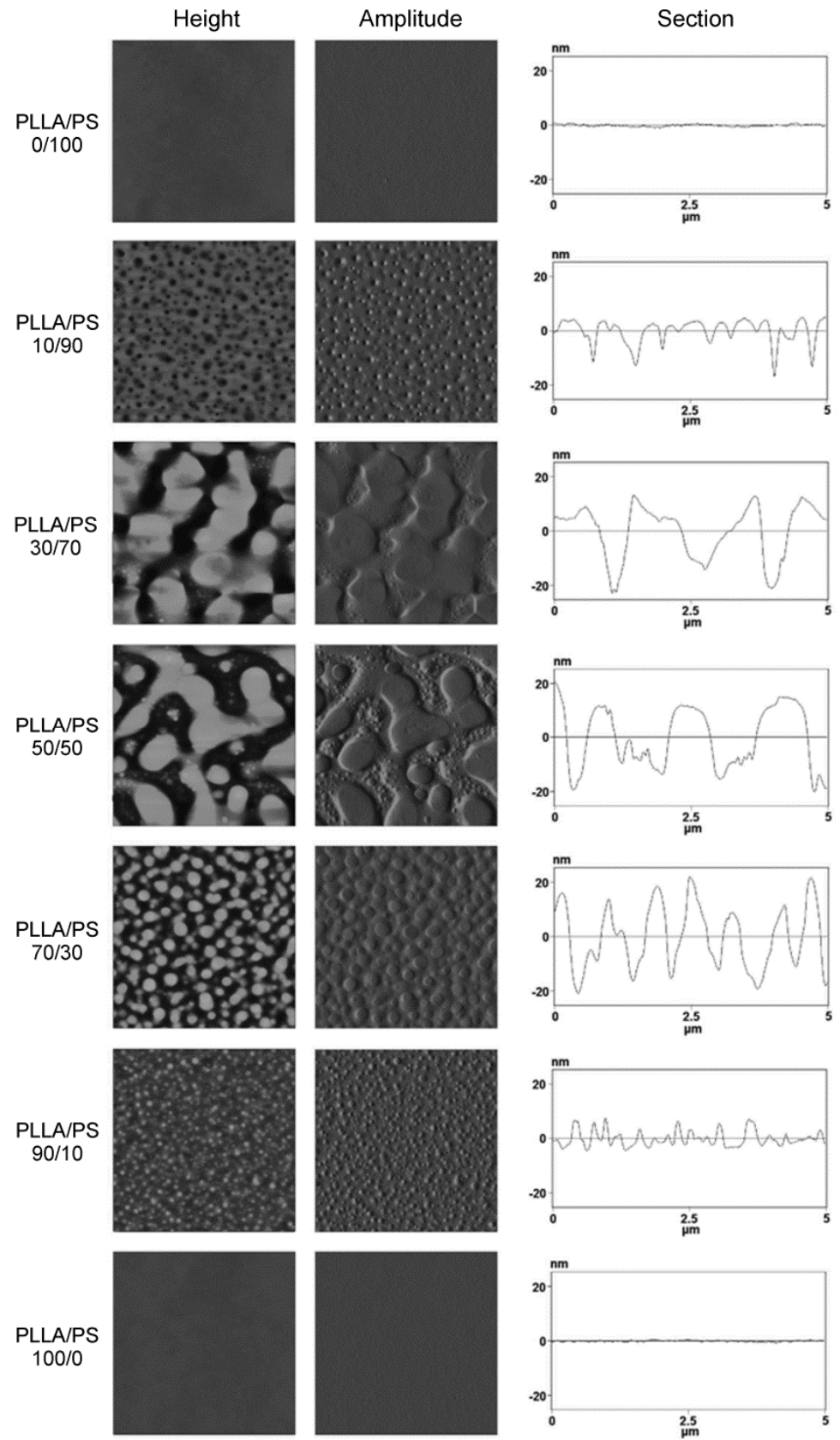

Figure 4.1 AFM images for the PLLA/PS nanotopographies as obtained from solutions of different polymer ratios. 
The height of the elevated areas in the sample depends non-monotonically on the PLLA content, as shown in the sections displayed in Figure 4.1 and the corresponding quantification, performed with the AFM software, in Figure 4.2 (squares). Sub-10nm features are found for low and high PLLA contents (10/90, 90/10) and similar $20 \mathrm{~nm}$ features for the intermediate compositions (30/70, 70/30). By contrast, the fraction of the surface area covered by raised nanofeatures, calculated from AFM images by image analysis, decreases linearly as the amount of PLLA in the sample increases (circles in Figure 4.2). These results are in agreement with those values previously reported for this system [18].

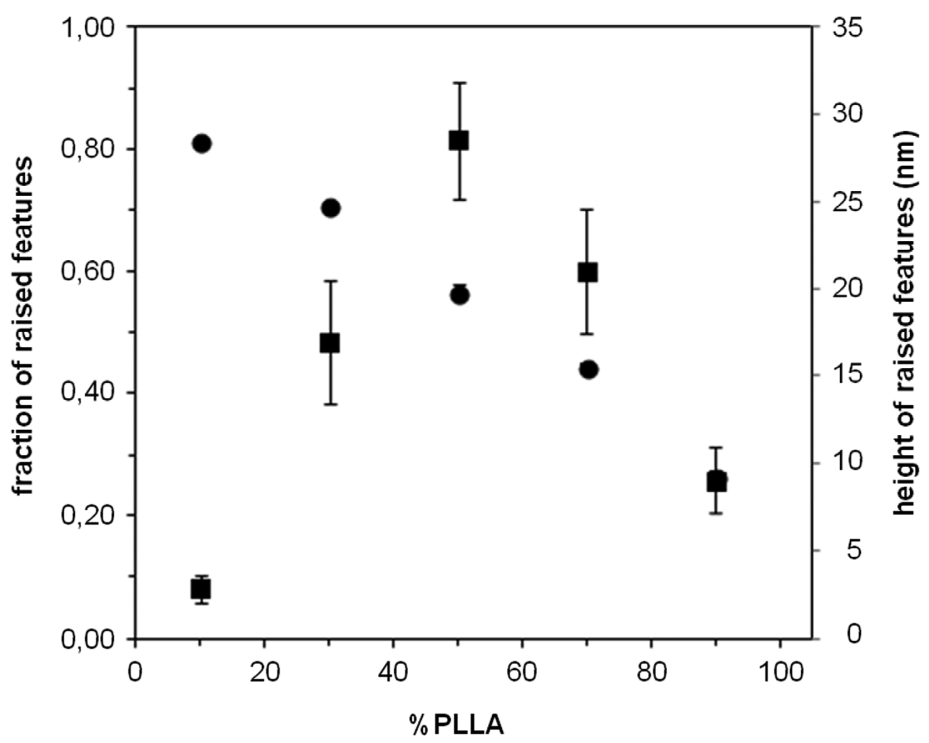

Figure 4.2 Fraction of raised features (circles) and their average height (squares). Error bar represents the standard deviation of three independent areas on the sample. When not visible, it is smaller than the symbol.

Even though surface topography is often only a manifestation of the underlying chemistry, it can also be modulated in an independent way. For this system, it is known that PLLA tends to be segregated onto the top surface, as obtained from SIMS and XPS [12]. That is to say, this system consists of 
nanotopographies with different geometrical patterns whose surface consists mostly of PLLA, especially for samples which have a total PLLA content higher than $30 \%$, where the fraction of PLLA on the surfaces is higher than $96 \%$ [18]. Therefore, the effect on cell behaviour must be ascribed to different nanometric patterns rather than to the effect of surface chemistry.

The surface of the sample with 10\% PLLA consists of approximately $70 \%$ PLLA [7]. For this reason, the water contact angle decreases from $93^{\circ}$ for the hydrophobic PS to $85^{\circ}$ for the sample with 10\% PLLA (but with $30 \%$ PS on the surface) and then it stabilizes at approximately $75^{\circ}$ for the rest of the samples (Figure 4.3), supporting the presence of similar PLLA surface chemistries, regardless of the underlying nanotopography obtained as a consequence of the phase separation process during spin-casting. The small variations observed in the water contact angle measured on samples with PLLA content higher than $10 \%$ can be caused by the different underlying nanotopography.

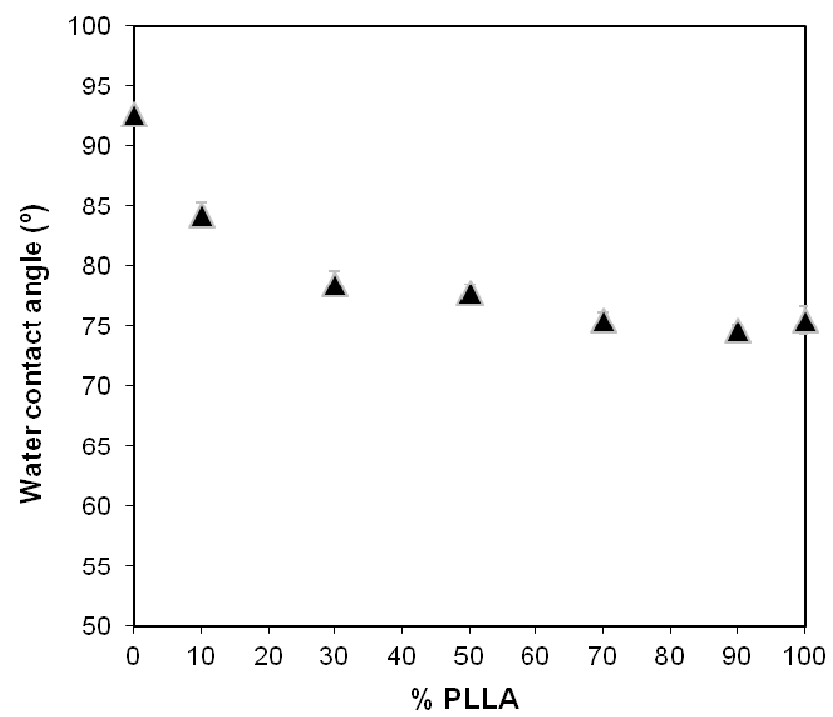

Figure 4.3 Water contact angle on the different nanoscale topographies. Error bar represents the standard deviation of three independent areas on the sample. When not visible, it is smaller than the symbol. 
Therefore, this system consists on several nanoscale topographies of similar chemistry, with different geometrical features and different sizes.

We have recently assessed the initial cell adhesion on these nanostructures, mediated by the FN distribution on them, and well-developed focal adhesion and F-actin cytoskeleton formation was found for each substrate [33]. To investigate the effect of the nanotopography size on protein adsorption and cell response, ruling out the effect due to different geometrical features, a second system of PLLA/PS nanotopographies was prepared. We chose the intermediate composition (50/50) from which a nanotopography which consists of peaks and valleys was obtained. In this nanostructure the surface fraction covered by both high and low areas is similar and the fraction of PLLA on its surface was higher than 93\% [7]. To obtain PLLA/PS nanostructures of different sizes, solutions of fixed composition of both polymers (50/50) and different total polymer concentration were prepared and the nanotopographies were obtained by spin casting of the solutions, as described elsewhere [7].

\section{Nanopits of different sizes}

Figure 4.4 shows AFM height images of PLLA/PS (50/50, w/w) nanotopographies as obtained by demixing during high-speed spin-casting on glass coverslips of various solutions of different concentration in chloroform: $0.5,1$ and $1.5 \%$. In this way, three nanotopographies which consists on high areas (peaks) and low areas (valleys) with different deep pits (14, 29 and $45 \mathrm{~nm}$ respectively) were obtained. Hereafter we will refer to the various nanotopographies with the corresponding depth of pit: 0.5\% (14 nm deep pits), $1 \%$ (29 nm deep pits) and 1.5\% (45 nm deep pits).

In Figure 4.4, the first row corresponds to the height magnitude for the three nanotopographies, the second one is a transversal cut (where deep pits of the different nanotopographies can be observed) and the last one shows a $3 \mathrm{D}$ reconstruction of the surfaces. A flat substrate was obtained from spin-casting 
of a solution of pure PLLA, and it is employed as a control respect to the nanoscale topographies.
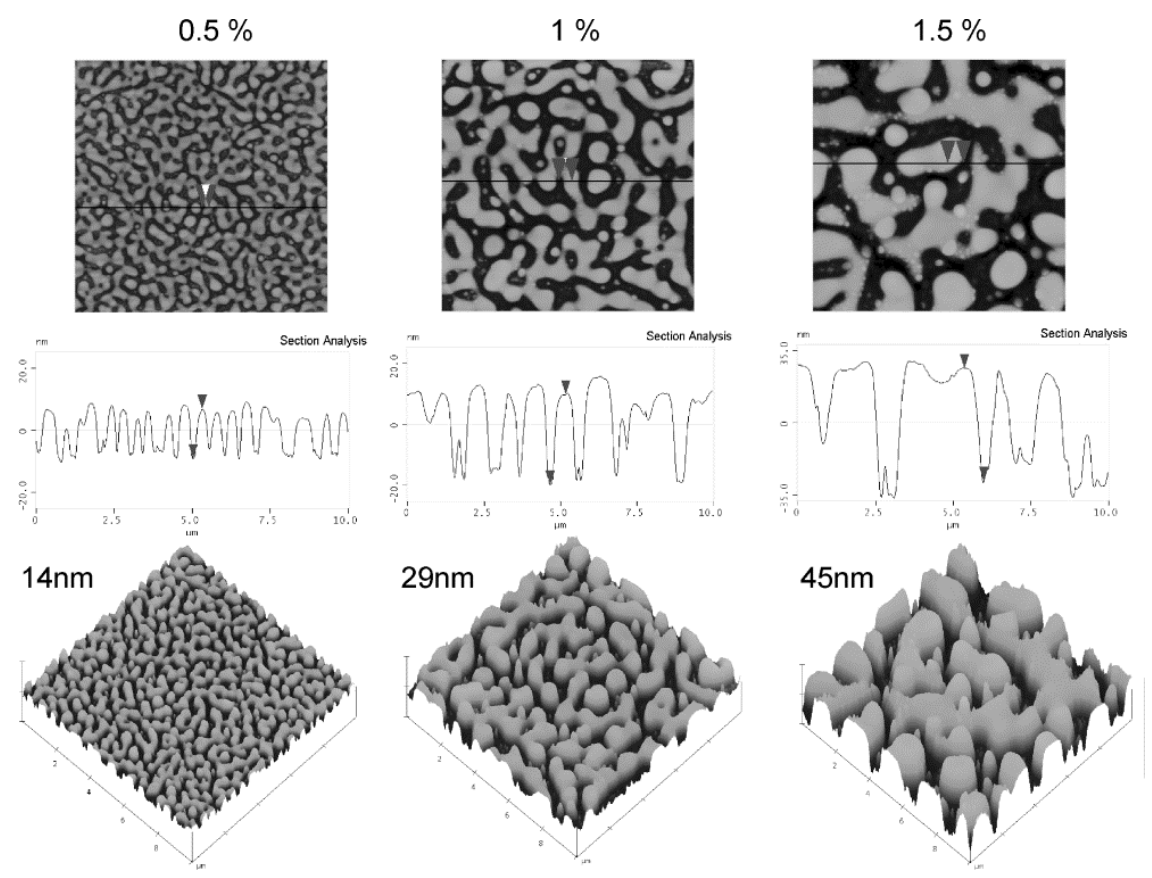

Figure 4.4 AFM images for the PLLA/PS (50/50, w/w) demixed nanotopographies as obtained after spin casting from solutions of concentrations $0.5,1$ and $1.5 \mathrm{wt} \%$ in chloroform.

The fraction of the total area covered of pits (determined by image analysis) is similar for the three nanotopographies (approximately 55\%), thus it does not depend on the individual topographic scale. The samples showed increased values for the real 3D surface area: $5 \mu \mathrm{m} \times 5 \mu \mathrm{m}$ AFM images showed 25.15 , 25.20 and $25.30 \mu \mathrm{m}^{2}$ for 14,29 and $45 \mathrm{~nm}$ deep pits respectively. These values are in agreement with those reported previously for this system [7]. Moreover, not only the vertical size of the topography changes for the different substrates, but also the characteristic horizontal area of the pits which is approximately $0.08,0.2$ and $0.5 \mu \mathrm{m}^{2}$ for the 14,29 and $45 \mathrm{~nm}$ deep pits nanotopographies respectively. The mean roughness of the different nanotopographies, also 
increased as the deep pits did, as observed in Figure 4.5 (Ra: arithmetic average of the height deviations from the center plane).

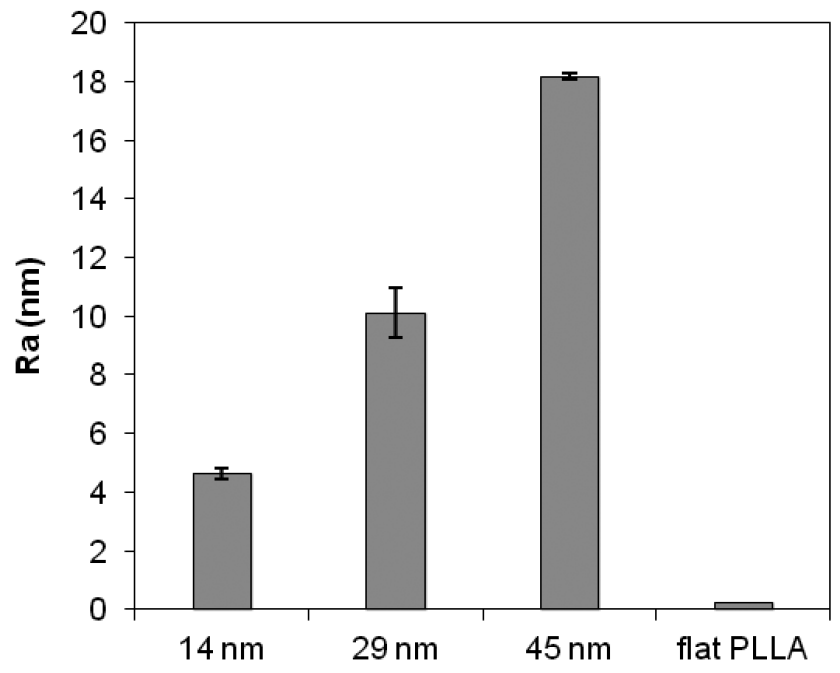

Figure 4.5 Mean roughness $(\mathrm{Ra})$ of the different nanotopographies and flat PLLA.

Besides, since PLLA tends to segregate to the air-film interface (the fraction of PLLA on the three surfaces is higher than 93\%, as confirmed by SIMS and XPS [7, 18], the system consists of different nanotopographies with the same surface chemistry. In fact, the three nanotopographies have similar wettability (i.e. water contact angle around $77^{\circ}$ ). Therefore, the system is appropriate for investigating the effect of surface nanotopography on the cell-protein-material interaction independently of the surface chemistry that is kept constant. This is an important matter since protein adsorption is mostly affected by the material surface and, consequently, cells are only sensitive to the topmost surface chemistry of the films. The layer of interest for protein adsorption and cell adhesion consists of PLLA nanopits of different sizes. 


\subsubsection{Fibronectin adsorption}

\section{$\underline{\text { Protein quantification }}$}

Figure 4.6 shows the amount of FN adsorbed on the different substrates (the nanopits and flat PLLA) from solutions of different concentrations, i.e. 2, 10 and $20 \mu \mathrm{g} / \mathrm{ml}$ for $60 \mathrm{~min}$, as obtained by radiolabelling of FN with ${ }^{125} \mathrm{I}\left({ }^{125} \mathrm{I}-\mathrm{FN}\right)$. For a fixed nanotopography, the amount of adsorbed $\mathrm{FN}$ increases as the concentration of the protein solution does. For a fixed concentration of the FN solution, the amount of adsorbed protein is higher on the $14 \mathrm{~nm}$ deep pits surface compared to the 29 and $45 \mathrm{~nm}$ deep pits nanotopographies on which the amount of adsorbed FN is similar. In concrete, when adsorbing from the 20 $\mu \mathrm{g} / \mathrm{ml} \mathrm{FN}$ solution - which is the concentration of the solution used in cell culture later on $-2250 \mu \mathrm{g} / \mathrm{m}^{2}$ of the protein were adsorbed on the $14 \mathrm{~nm}$ deep pit surface which lowers to approximately $1500 \mu \mathrm{g} / \mathrm{m}^{2}$ for the other two surfaces (29 and $45 \mathrm{~nm}$ deep pits). That is to say, the amount of adsorbed FN is approximately $50 \%$ higher on the $14 \mathrm{~nm}$ deep pit nanotopography. Therefore, the amount of adsorbed $\mathrm{FN}$ depends on the topographical nanostructure of the substrate. This phenomenon is remarkable since suggesting a direct influence of surface topography on protein adsorption (since the same surface chemistry is obtained for every substrate). This different amount of adsorbed FN cannot be explained by small differences in the real three dimensional areas among nanotopographies (less than $3 \%$ ). 


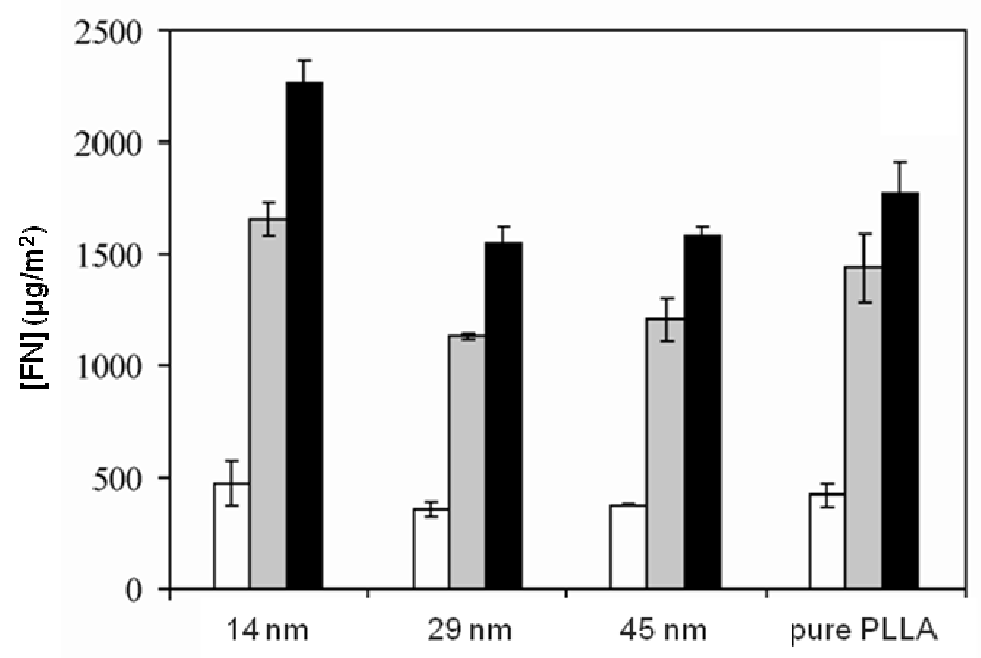

Figure 4.6 Quantification of FN adsorption by radioactivity. Surface density of FN after adsorption from solutions of concentration $2 \mu \mathrm{g} / \mathrm{ml}$ (white), $10 \mu \mathrm{g} / \mathrm{ml}$ (gray), and $20 \mu \mathrm{g} / \mathrm{ml}$ (black).

The exchangeability of FN molecules bound to the surfaces was evaluated by the exchange of the preadsorbed ${ }^{125} \mathrm{I}-\mathrm{FN}$ for unlabelled FN. Figure 4.7 shows the percentage of ${ }^{125} \mathrm{I}-\mathrm{FN}$ retained on the different surfaces after $60 \mathrm{~min}$ of adsorption and the posterior elution by other FN molecules during $24 \mathrm{~h}$ in an unlabeled $F N$ solution of $20 \mu \mathrm{g} / \mathrm{ml}$. It can be seen that all three nanotopographies and flat PLLA shows similar behavior and only approximately $10 \%$ of the initially adsorbed $\mathrm{FN}$ is eluted. The same experiment was done on glass coverslips, and the fraction eluted from the surface was significantly higher, approximately $20 \%$ of the initial adsorbed FN. 


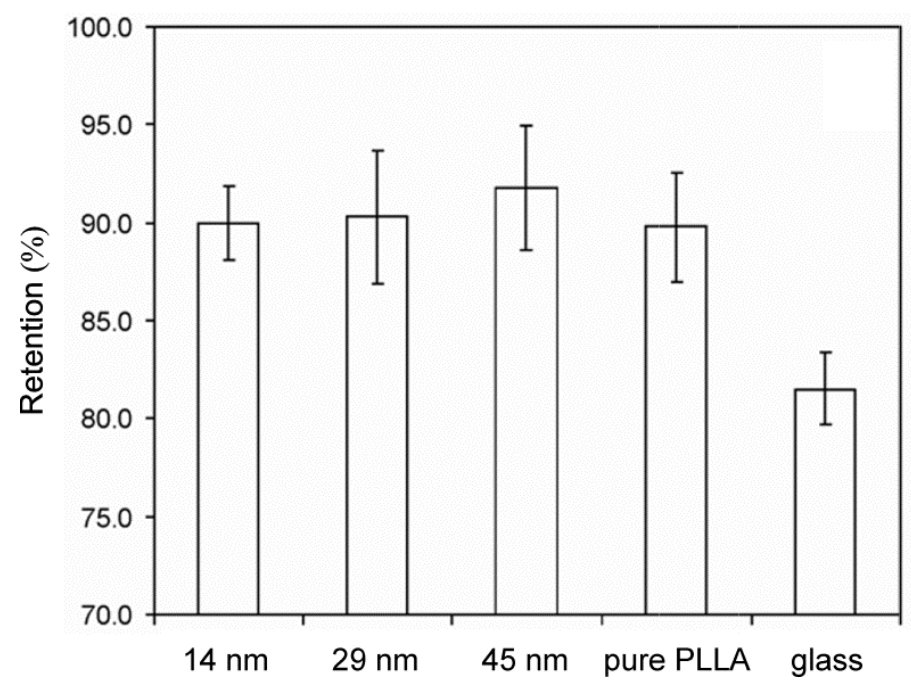

Figure 4.7 Retention of FN molecules on the surface after 60 min of adsorption and posterior elution for $24 \mathrm{~h}$.

The exchangeability of FN molecules by other FN molecules provides an idea of the strength of interaction between the adsorbed protein layer and the material surface.

\section{FN conformation and distribution}

FN conformation and distribution on the three nanotopographies was assessed by AFM. Figure 4.8-4.10 show the AFM height (first row) and phase (second row) magnitudes for the different nanotopographies after $\mathrm{FN}$ adsorption during $10 \mathrm{~min}$ from solutions of concentration 2, 5, 10 and $20 \mu \mathrm{g} / \mathrm{ml}$ respectively. FN molecules are better identified on the phase image, while the height magnitude can be used for identifying, simultaneously, the spatial distribution of FN throughout peaks and valleys in the sample. Only isolated molecules are observed after adsorption from the solution of concentration 2 $\mu \mathrm{g} / \mathrm{ml}$, which associate into small aggregates which results in a continuous protein layer on the sample after adsorption from solutions of higher concentrations (10 and $20 \mu \mathrm{g} / \mathrm{ml}$ respectively). 


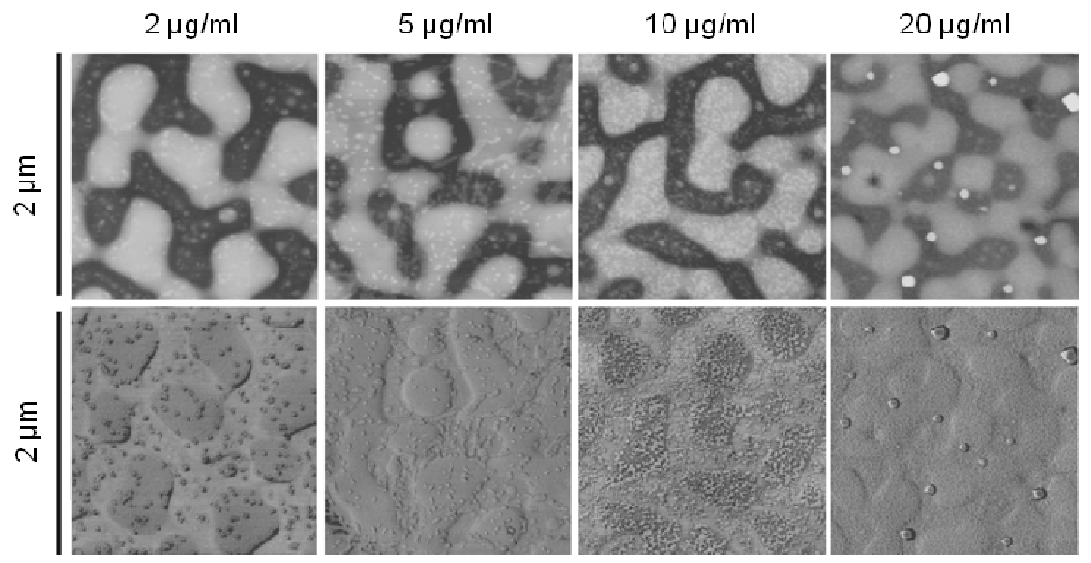

Figure 4.8 Conformation and distribution of the $\mathrm{FN}$ adsorbed on the $14 \mathrm{~nm}$ deep pit nanotopography at different concentrations. Height (first row) and phase (second row) AFM magnitudes.

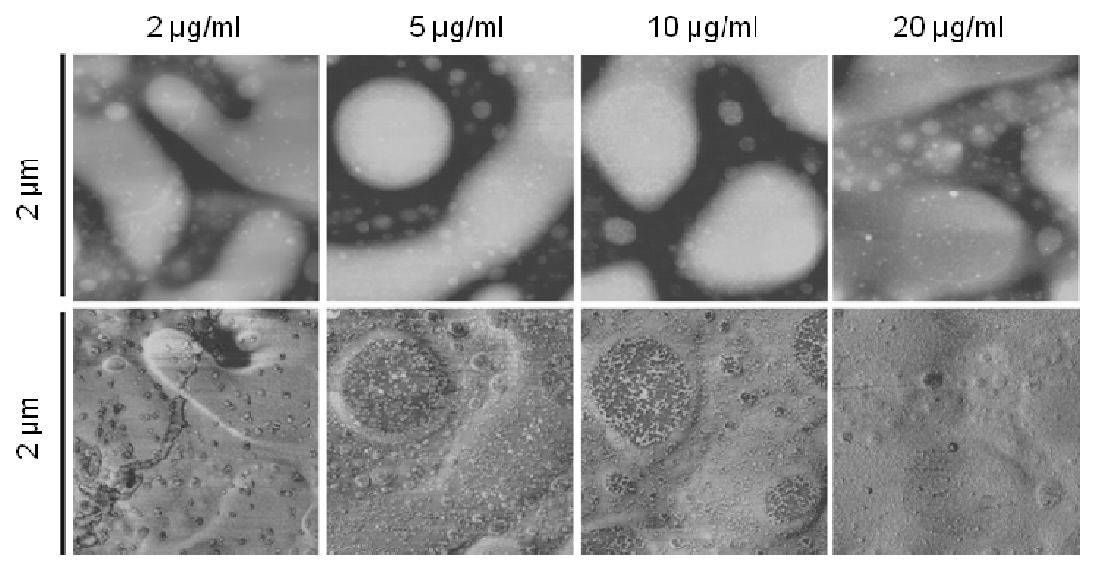

Figure 4.9 Conformation and distribution of the $\mathrm{FN}$ adsorbed on the $29 \mathrm{~nm}$ deep pit nanotopography at different concentrations. Height (first row) and phase (second row) AFM magnitudes. 

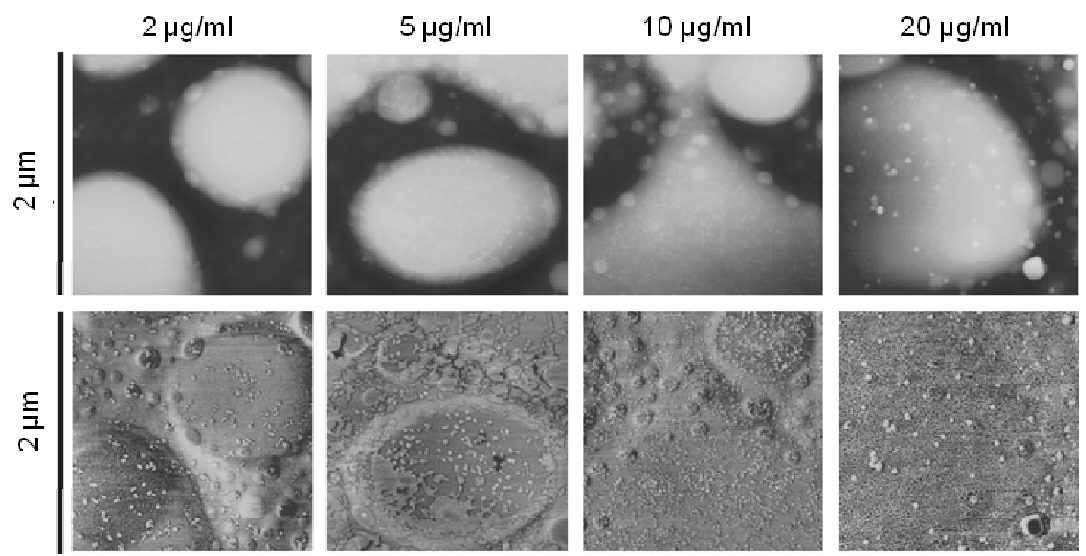

Figure 4.10 Conformation and distribution of the $\mathrm{FN}$ adsorbed on the $45 \mathrm{~nm}$ deep pit nanotopography at different concentrations. Height (first row) and phase (second row) AFM magnitudes.

Image analysis of the AFM figures allows one to quantify the distribution of molecules between peaks and valleys of the nanostructure, after adsorption from solutions of different concentrations (Figure 4.11). It is observed that, for the $14 \mathrm{~nm}$ deep pits, $\mathrm{FN}$ is preferentially adsorbed on the valleys of the nanostructure when the concentration of the solution is lower than $10 \mu \mathrm{g} / \mathrm{ml}$ (squares in Figure 4.11). However, $\mathrm{FN}$ is evenly distributed between valleys and peaks of the samples when adsorbed from solutions of 10 and $20 \mu \mathrm{g} / \mathrm{ml}$ (FN concentration employed for protein coating in cellular cultures). FN distributes randomly between pits and valleys independently of the concentration of the solution when adsorbed on the 29 and $45 \mathrm{~nm}$ deep pits nanotopographies (triangles in Figure 4.11). 


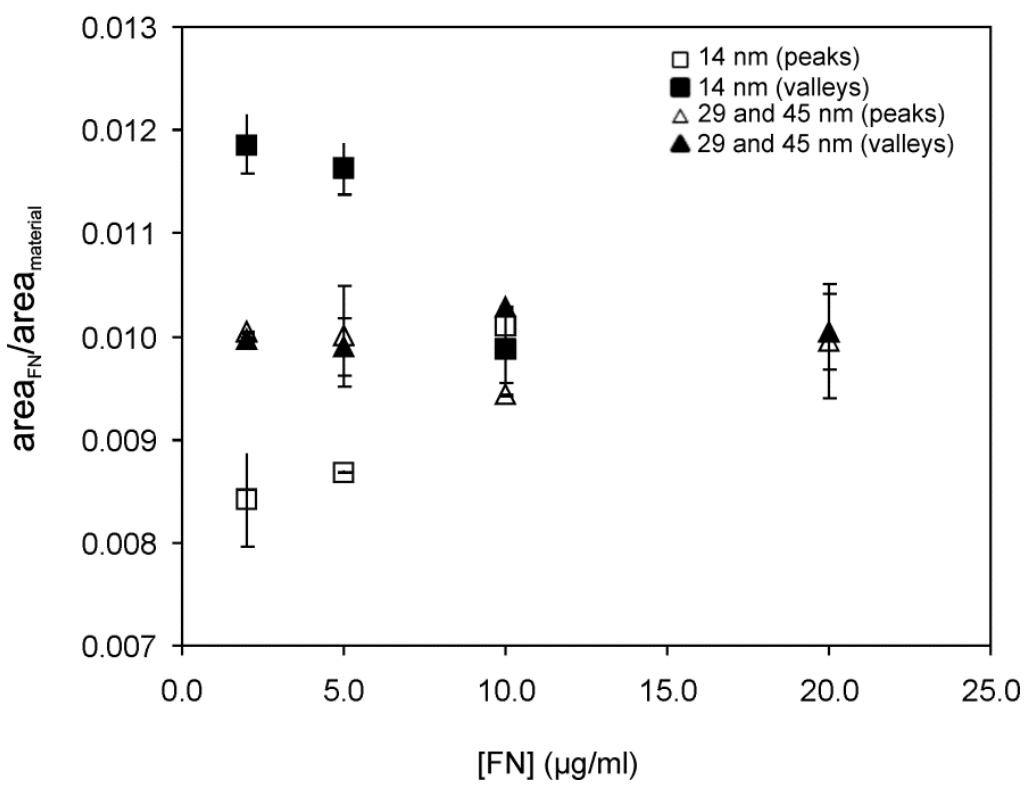

Figure 4.11 Fraction of the area covered by FN relative to the area of the peaks (empty symbols) and valleys (filled symbols).

\subsubsection{Cell adhesion and FN matrix formation}

\section{Initial cell adhesion}

Figure 4.12 shows the overall morphology of MC3T3 cells adhering for $3 \mathrm{~h}$ on FN-coated nanotopographies and flat PLLA, visualized via staining for actin (left column). Cells presented prominent actin fibers inserting into welldeveloped focal adhesion complexes, as depicted in the central column for vinculin. The third column is the superposition of the other two. Nuclei were counterstained with DAPI. 


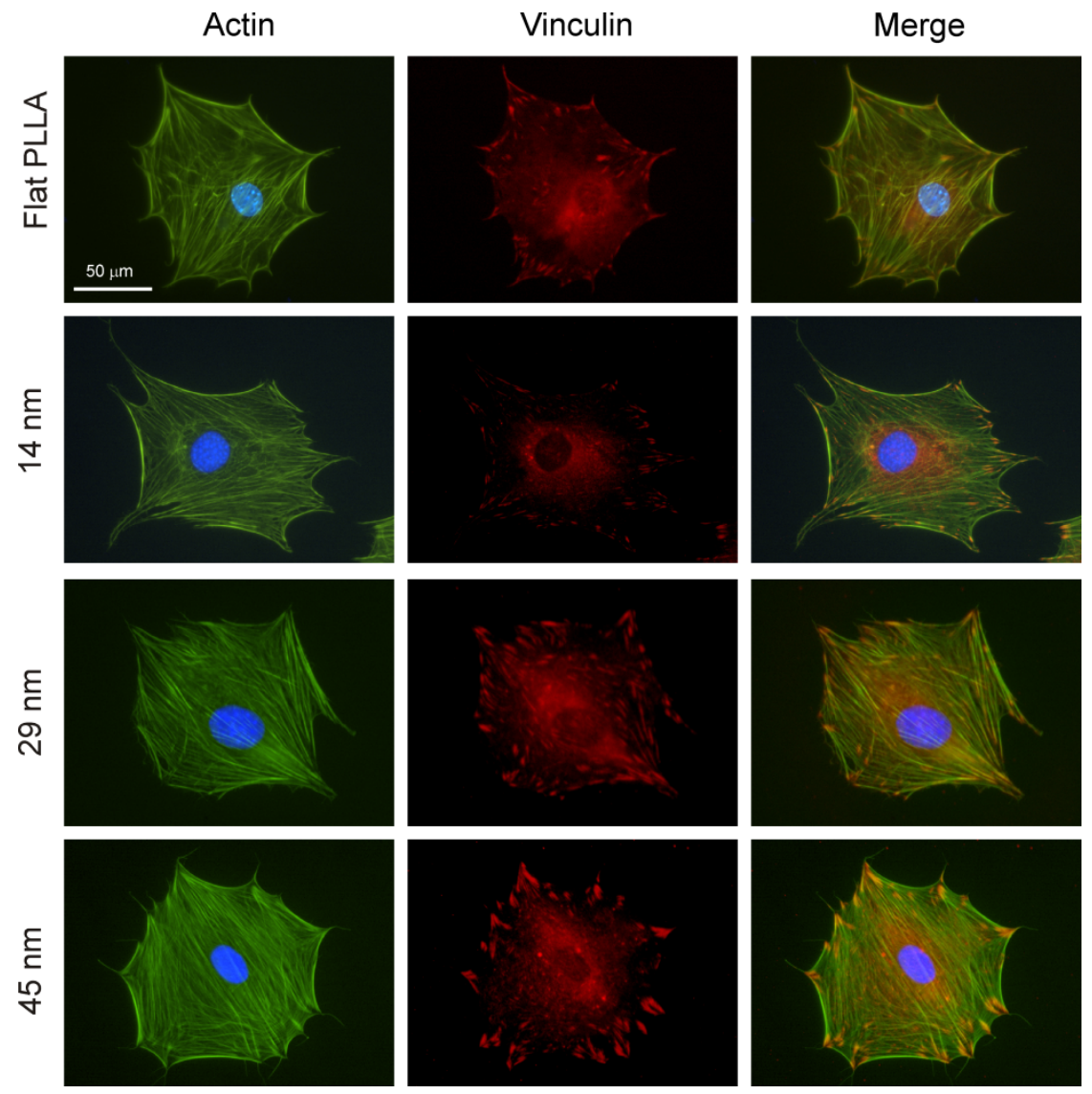

Figure 4.12 MC3T3 osteoblast-like cells after 3h on FN-coated nanotopographies.

It is clearly observed that the size of focal complexes increases as the size of the nanotopography does, from the $14 \mathrm{~nm}$ deep pits nanotopography to the $45 \mathrm{~nm}$ pits one, which can be quantified by image analysis. Figure 4.13 shows the size distribution of focal adhesion complexes for the three nanotopographies, as well as an example of the sequential process described above to delimitate focal adhesion plaques from the original image (see experimental section). 


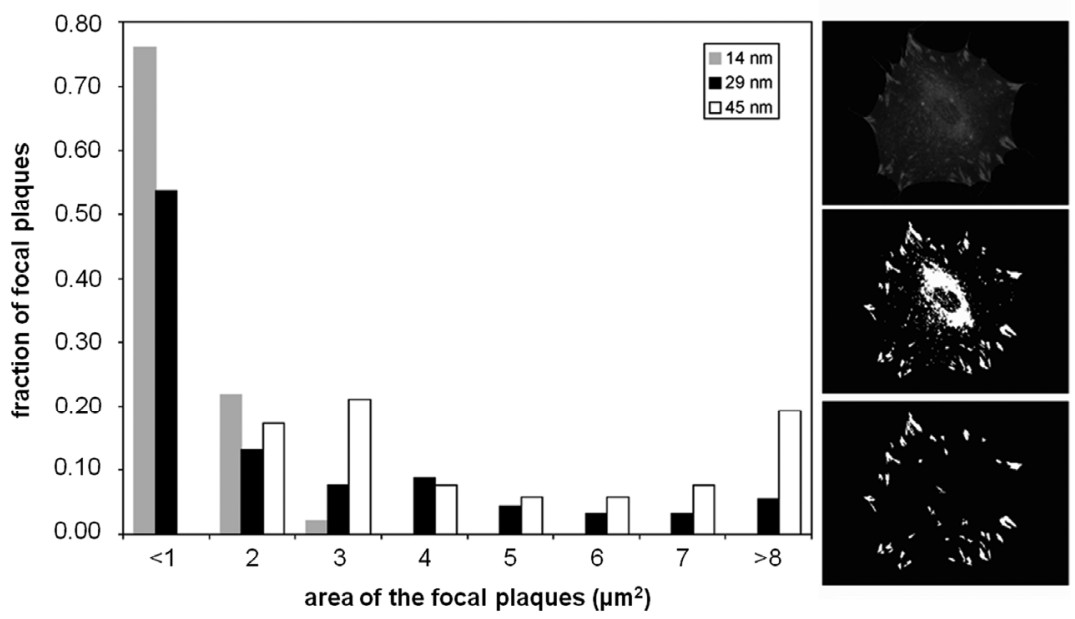

Figure 4.13 Size distribution of focal adhesion plaques on each nanotopography as quantifed by image analysis.

Small focal complexes are found for the $14 \mathrm{~nm}$ deep pits topographies, such that the whole distribution is below $3 \mu \mathrm{m}^{2}$ and $75 \%$ below $1 \mu \mathrm{m}^{2}$. The size distribution expands up to $8 \mu \mathrm{m}^{2}$ on the $29 \mathrm{~nm}$ deep pits, while still $70 \%$ of the values below $2 \mu \mathrm{m}^{2}$. The distribution is completely altered for the focal plaques formed on the $45 \mathrm{~nm}$ deep pits topography: there is no focal plaque smaller than $1 \mu \mathrm{m}^{2}, 40 \%$ of them are in the range of $2-3 \mu \mathrm{m}^{2}$ and approximately $25 \%$ are larger than $1 \mu^{2}$ (Figure 4.13).

The effect of this concrete family of substrates on human fetal osteoblastic (hFOB) cells was previously investigated in the literature [7]. There, it was found that cell adhesion was enhanced on the $14 \mathrm{~nm}$ deep pits nanotopography, in agreement with other studies [34-35]. Moreover, focal adhesion development in hFOB was found to be enhanced on 14 and $29 \mathrm{~nm}$ pit surfaces; however, only paxillin expression was altered while vinculin did not display significantly altered expression with respect to nanopit textures [7]. However, the results obtained in this work show that vinculin distribution throughout the cell periphery, organized in focal adhesion plaques, is modified as a consequence of the underlying nanotopography. The horizontal area of the pits on the material surface - 
correlated to the height of the nanopits - tailors the size of focal adhesion sites, which are larger as the z-axis scale dimension of the structure increases (Figure 4.12). This behavior must be a consequence of the availability of the adsorbed FN layer on the material surface which is influenced by the underlying nanotopography. It has been reported that cells were able to form larger focal contacts on nanostructure materials [10], but a clear trend and its frequency distribution had not been reported so far.

It is important to remark that this study was done in serum free conditions, which allows to characterize the cell-material interface in terms of the amount of FN adsorbed and its conformation, evaluating the specific cell-FN interaction, which is an important difference with respect to previous investigations on this family of nanotopographies [7].

FN was equally distributed between pits and valleys after adsorption from a solution of concentration $20 \mu \mathrm{g} / \mathrm{ml}$ (Figure 4.11) - the one used for coating samples before cell culture - and the surface FN density adsorbed on 29 and 45 $\mathrm{nm}$ deep pit nanotopographies was the same, whereas the size of focal adhesions was different on these substrates, which suggests that the total amount of the adsorbed FN and its distribution does not influence in the size of the focal plaques. Therefore, vinculin distribution on the different nanotopographies must be a consequence of the local organization (at the nanoscale) of the underlying material surface - which is covered by a uniform layer of the protein - considering both the vertical and horizontal dimensions of the pits, and not due to either the difference in the amount of adsorbed protein (Figure 4.6), or the influence of nanotopography on the conformation and distribution of the adsorbed FN molecules (Figure 4.8-4.10).

On the other hand, vinculin level at adhesion sites has been correlated in a linear manner with tractional forces exerted by cells, so that tension needs to be developed between the ECM and the adhesion site for vinculin recruitment [11, 36]. The formation of mature focal adhesions occurs through integrin clustering 
via increased force generated by the cytoskeleton [37], thus less mature cytoskeleton suggests that less tension is applied to integrins resulting in less clustering and smaller contacts [38]. We have not found any difference in the state of development of actin cytoskeleton on the different nanotopographies (Figure 4.12) regardless the size of the focal contact plaques which suggests that the size of the adhesion contacts, being directly modulated by the available area on the nanopits, are large enough so as to allow cell adhesion and mechanotransduction via actin cables.

\section{FN matrix formation and organization}

Figure 4.14 shows the cellular reorganization of adsorbed $\mathrm{FN}$ after $3 \mathrm{~h}$ of culture for the different nanotopographies, flat PLLA and the control glass. It is observed that cells are able to reorganise $\mathrm{FN}$ on the control glass as it is shown by the dark area around the pericellular edge (now absent of FN), specially when comparing the actin cytoskeleton (right column) and the staining for FN (left column). Reorganization occurs much less actively for flat PLLA and the different nanotopographies. It is shown that some movements of the adsorbed FN layer takes place in any case but the dark areas in the pericellular zone are smaller and mostly coincident with focal adhesion plaques. Reorganization takes place preferentially on the 29 and $45 \mathrm{~nm}$ deep pits nanotopographies and it is almost absent for the $14 \mathrm{~nm}$ deep pit structure (Figure 4.14). 


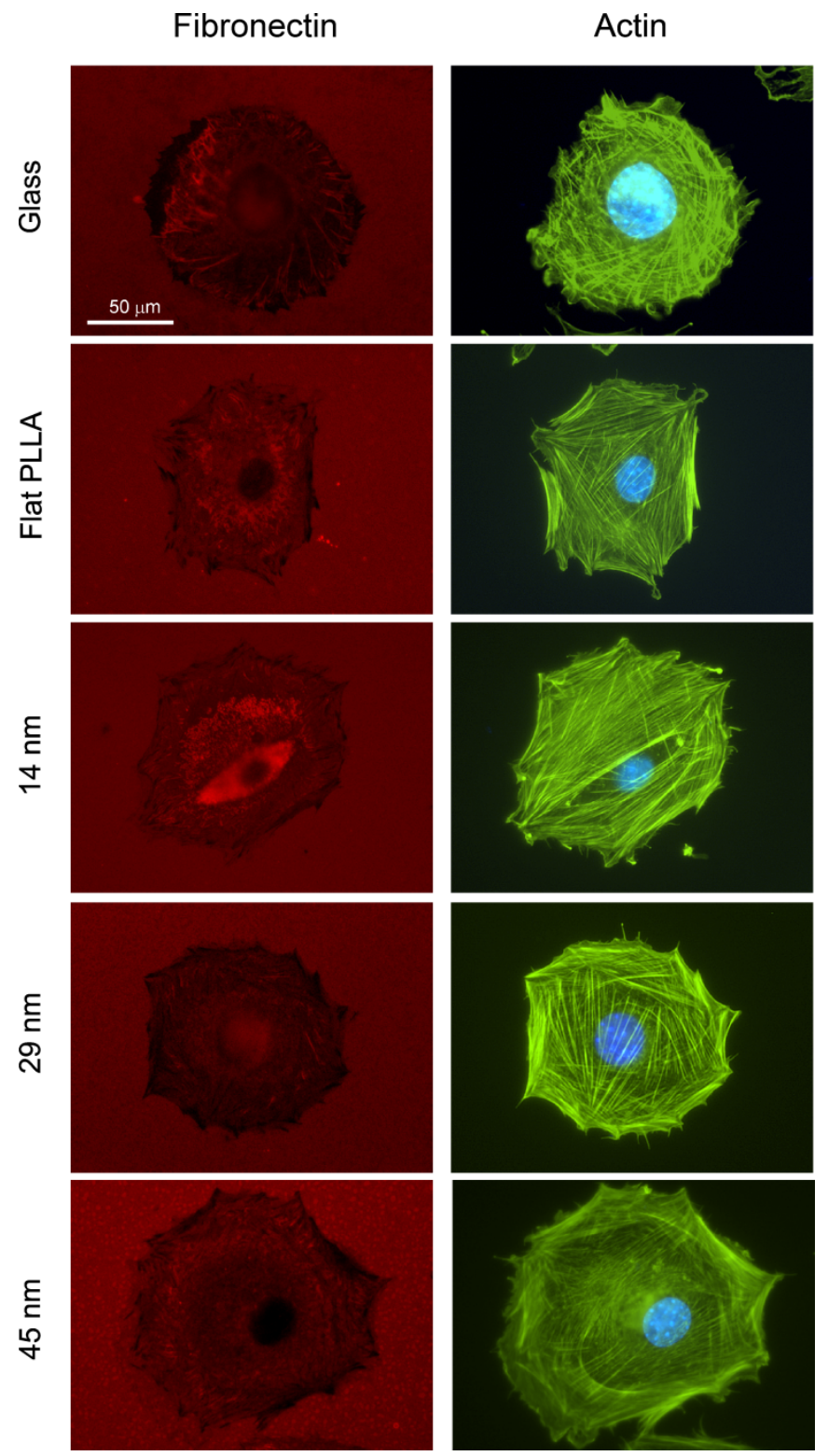

Figure 4.14 Cellular reorganization of adsorbed $\mathrm{FN}$ on the different nanotopographies, flat PLLA and glass. 
As observed in Figure 4.14, FN reorganization is more important on the underlying glass, a hydrophilic substrate that bounds proteins loosely and leads to strong cell rearrangement of the adsorbed protein layer [39]. Previous investigations have shown that for cells to remove and reorganize the adsorbed FN layer in matrix fibrils, material need to adsorb proteins loosely [40-43]. The strength of interaction between the adsorbed protein layer and the material surface is related to the exchangeability of FN molecules by other FN molecules or other proteins after adsorption [44]. In our case, the strength of interaction between the adsorbed FN molecules and the underlying substrate must be similar for each nanotopography, since the elution of bound $\mathrm{FN}$ molecules showed no differences among the different substrates (Figure 4.7). However, FN elution is higher on glass which means lower strength of adhesion and higher cellular reorganization.

The size of the focal adhesion plaques is related to the ability of cells to rearrange the adsorbed protein layer. Matrix reorganization takes place via integrin-FN interaction, involving the transmission of forces from the actin cytoskeleton to the ECM via focal adhesion plaques [38]. We have found that, even PLLA is a material on which FN reorganization is highly difficult (Figure 4.14), the presence of nanopits provides some degrees of freedom for cellmediated FN rearrangements, more the larger the nanopit size (Figure 4.14).

Figure 4.15 shows late $F N$ matrix formation for the different nanotopographies and flat PLLA after different culture times. It is observed that, as expected, matrix production increases as time goes by on every substrate. Cells are able to secrete their own extracellular matrix on flat PLLA, but matrix deposition is strongly affected by substrate's nanostructure. 


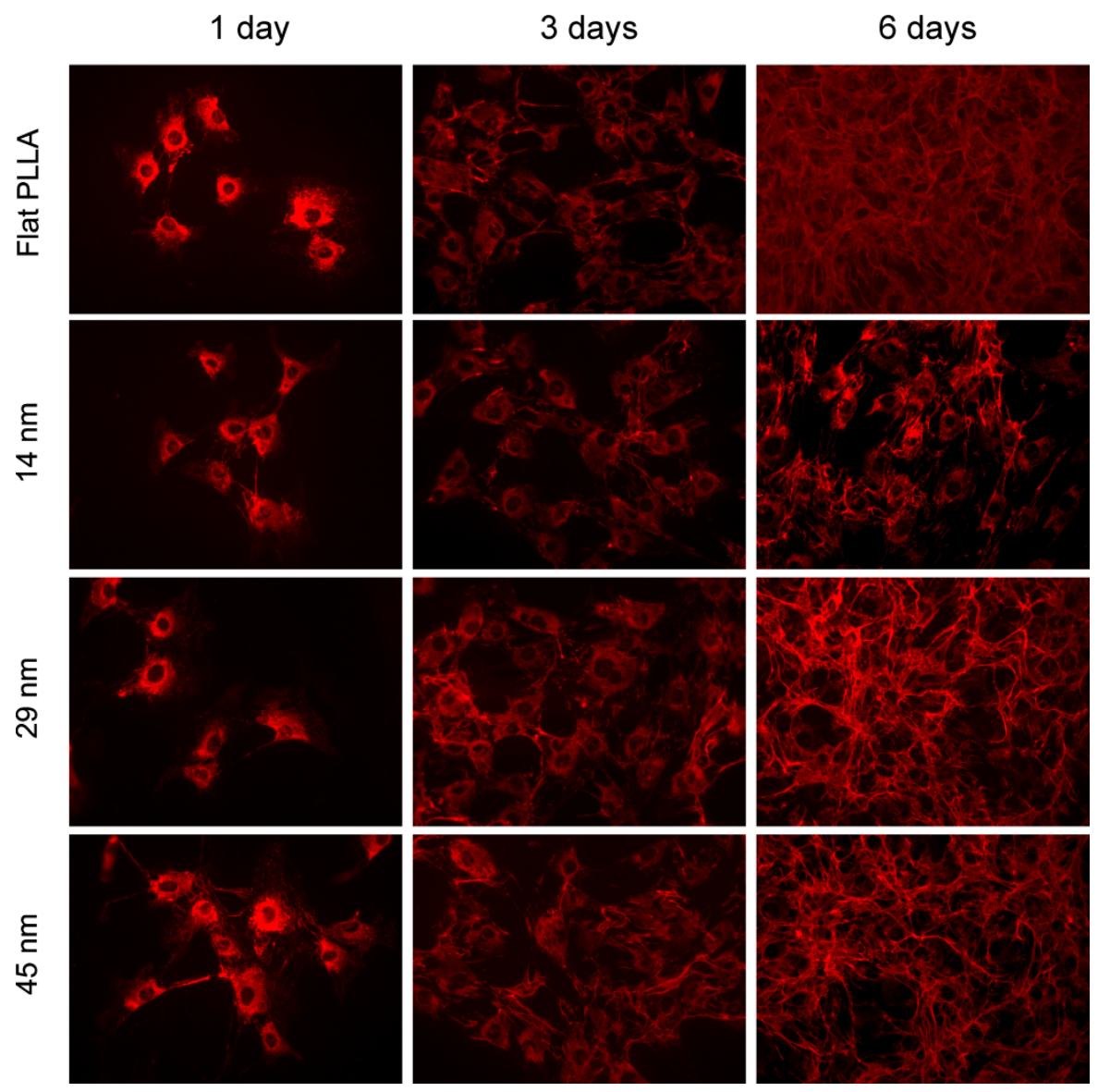

Figure 4.15 Dynamics of fibronectin matrix formation on the different nanotopographies and the flat PLLA.

Late matrix formation has been related to the ability of cells to rearrange the initially adsorbed protein layer [41-42, 45]. Cells are able to synthesize and deposit FN matrix fibrils - more abundantly and better organized into fibrillar networks - for the 29 and $45 \mathrm{~nm}$ deep pits nanotopographies rather than the 14 $\mathrm{nm}$ deep pits one, where scarce FN formation is obtained. This must be related to the fact that matrix reorganization is almost absent on this surface. On the contrary, when the initial FN layer is reorganized by the adhered cell, FN formation takes place more abundantly. This fact suggests that late matrix formation is in need not only of cell adhesion on the substrate, but some cell 
movements, in the range of the size of the focal adhesion plaques, must take place so matrix deposition takes place normally.

\subsection{Conclusions}

The results of this work suggest the importance of the adsorbed FN layer in cellular response to different nanotopographies.

FN adsorption depends on the size of the nanostructure, i.e. the amount of adsorbed $\mathrm{FN}$ is higher on the $14 \mathrm{~nm}$ deep substrate than the other two ones (29 and $45 \mathrm{~nm}$ deep pits). The protein conformation and distribution between valleys and peaks is similar when FN adsorption takes place from solutions of concentration of $10 \mu \mathrm{g} / \mathrm{ml}$ or higher (thus including the concentration employed in cell cultures, $20 \mu \mathrm{g} / \mathrm{ml}$ ).

The distribution of focal adhesions (vinculin) is strongly affected by the size of the nanopits. When focal adhesion plaques are too small (in $14 \mathrm{~nm}$ deep pit nanotopography), even if cells are able to adhere on the substrate and they develop the actin cytoskeleton, there is no trace of reorganization for the adsorbed FN layer which, in the long term, leads to diminishing functionality in the formation of the new matrix. In nanotopographies with higher deep pits (29 and $45 \mathrm{~nm}$ ), where focal adhesion plaques are more developed, the adsorbed FN layer is more reorganized, which results in higher production and organization of new FN matrix. 


\subsection{References}

1. J.Y. Wong, J.B. Leach, X.Q. Brown. Balance of chemistry, topography, and mechanics at the cell-biomaterial interface: Issues and challenges for assessing the role of substrate mechanics on cell response. Surface Science, 2004. 570, 119133.

2. P.T. Ohara, R.C. Buck. Contact guidance in vitro: A light, transmission, and scanning electron microscopic study. Experimental Cell Research, 1979. 121, 235249.

3. J.Y. Lim, H.J. Donahue. Cell sensing and response to micro- and nanostructured surfaces produced by chemical and topographic patterning. Tissue Engineering, 2007. 13, 1879-1891.

4. S. Affrossman, M. Stamm. The effect of molecular weight on the topography of thin films of blends of poly(4-bromostyrene) and polystyrene. Colloid \& Polymer Science, 2000. 278, 888-893.

5. F.A. Denis, P. Hanarp, D.S. Sutherland, Y.F. Dufrêne. Fabrication of Nanostructured Polymer Surfaces Using Colloidal Lithography and Spin-Coating. Nano Letters, 2002. 2, 1419-1425.

6. M.J. Dalby, D. Giannaras, M.O. Riehle, N. Gadegaard, S. Affrossman, A.S.G. Curtis. Rapid fibroblast adhesion to $27 \mathrm{~nm}$ high polymer demixed nano-topography. Biomaterials, 2004. 25, 77-83.

7. J.Y. Lim, A.D. Dreiss, Z. Zhou, J.C. Hansen, C.A. Siedlecki, R.W. Hengstebeck, J. Cheng, N. Winograd, H.J. Donahue. The regulation of integrin-mediated osteoblast focal adhesion and focal adhesion kinase expression by nanoscale topography. Biomaterials, 2007. 28, 1787-1797.

8. O. Zinger, G. Zhao, Z. Schwartz, J. Simpson, M. Wieland, D. Landolt, B. Boyan. Differential regulation of osteoblasts by substrate microstructural features. Biomaterials, 2005. 26, 1837-1847.

9. M.J. Dalby, A. Hart, S.J. Yarwood. The effect of the RACK1 signalling protein on the regulation of cell adhesion and cell contact guidance on nanometric grooves. Biomaterials, 2008. 29, 282-289.

10. M.J. Dalby, N. Gadegaard, R. Tare, A. Andar, M.O. Riehle, P. Herzyk, C.D.W. Wilkinson, R.O.C. Oreffo. The control of human mesenchymal cell differentiation using nanoscale symmetry and disorder. Nature Materials, 2007. 6, 997-1003. 
11. M.J. Dalby, D. McCloy, M. Robertson, H. Agheli, D. Sutherland, S. Affrossman, R.O.C. Oreffo. Osteoprogenitor response to semi-ordered and random nanotopographies. Biomaterials, 2006. 27, 2980-2987.

12. H.L. Khor, Y. Kuan, L. Kukula, K. Tamada, W. Knoll, M. Moeller, D.W. Hutmacher. Response of Cells on Surface-Induced Nanopatterns: Fibroblasts and Mesenchymal Progenitor Cells. Biomacromolecules, 2007. 8, 1530-1540.

13. K. Cai, J. Bossert, K.D. Jandt. Does the nanometre scale topography of titanium influence protein adsorption and cell proliferation? Colloids and Surfaces B: Biointerfaces, 2006. 49, 136-144.

14. D.G. Bucknall. Influence of interfaces on thin polymer film behaviour. Progress in Materials Science, 2004. 49, 713-786.

15. P. Müller-Buschbaum, E. Bauer, O. Wunnicke, M. Stamm. The control of thin film morphology by the interplay of dewetting, phase separation and microphase separation. Journal of Physics: Condensed Matter, 2005. 17, S363.

16. C. Ton-That, A.G. Shard, R.H. Bradley. Surface feature size of spin cast PS/PMMA blends. Polymer, 2002. 43, 4973-4977.

17. L. Cui, Y. Ding, X. Li, Z. Wang,Y. Han. Solvent and polymer concentration effects on the surface morphology evolution of immiscible polystyrene/poly(methyl methacrylate) blends. Thin Solid Films, 2006. 515, 2038-2048.

18. J.Y. Lim, J.C. Hansen, C.A. Siedlecki, R.W. Hengstebeck, J. Cheng, N. Winograd, H.J. Donahue. Osteoblast Adhesion on Poly(I-lactic Acid)/Polystyrene Demixed Thin Film Blends: Effect of Nanotopography, Surface Chemistry, and Wettability. Biomacromolecules, 2005. 6, 3319-3327.

19. S. Walheim, M. Böltau, J. Mlynek, G. Krausch, U. Steiner. Structure Formation via Polymer Demixing in Spin-Cast Films. Macromolecules, 1997. 30, 4995-5003.

20. C. Ton-That, A.G. Shard, D.O.H. Teare, R.H. Bradley. XPS and AFM surface studies of solvent-cast PS/PMMA blends. Polymer, 2001. 42, 1121-1129.

21. X. Li, Y. Han, L. An. Surface morphology control of immiscible polymer-blend thin films. Polymer, 2003. 44, 8155-8165.

22. P. Müller-Buschbaum, J.S. Gutmann,M. Stamm. Control of surface morphology by the interplay between phase separation and dewetting. Journal of Macromolecular Science, Part B, 1999. 38, 577-592.

23. M. Geoghegan, R.A.L. Jones, R.S. Payne, P. Sakellariou, A.S. Clough, J. Penfold. Lamellar structure in a thin polymer blend film. Polymer, 1994. 35, 2019-2027. 
24. M. Geoghegan,G. Krausch. Wetting at polymer surfaces and interfaces. Progress in Polymer Science, 2003. 28, 261-302.

25. C. Ton-That, A.G. Shard, R. Daley,R.H. Bradley. Effects of Annealing on the Surface Composition and Morphology of PS/PMMA Blend. Macromolecules, 2000. 33, 8453-8459.

26. A. Budkowski, A. Bernasik, P. Cyganik, J. Raczkowska, B. Penc, B. Bergues, K. Kowalski, J. Rysz,J. Janik. Substrate-Determined Shape of Free Surface Profiles in Spin-Cast Polymer Blend Films. Macromolecules, 2003. 36, 4060-4067.

27. I. Amersham. lodine-125. 1993, Little Chalfont, Buckinghamshire, U.K.

28. R.S. Sousa, M.M. Brás, P. Moradas-Ferreira, M.A. Barbosa. Dynamics of Fibronectin Adsorption on TiO2 Surfaces. - Langmuir, 2007. 23, 7046-7054.

29. N. Otsu. A Threshold Selection Method from Gray-Level Histograms. IEEE Transactions on Systems, Man, and Cybernetics, 1979. 9, 62-66.

30. R.C. González, R.E. Woods, S.L. Eddins. Digital Image Processing Using MATLAB. 2003, Prentice-Hall, Upper Saddler River, NJ.

31. R.C. González, R.E. Woods. Digital Imaging Processing. 2007, Prentice-Hall, Upper Saddle River, NJ.

32. T. Mathworks. MATLAB Image Processing Toolbox User's Guide. 2006, Natick, MA. The MathWorks, Inc.

33. M. Pérez-Garnes, C. González-García, D. Moratal, P. Rico, M. Salmerón Sánchez. Fibronectin distribution on demixed nanoscale topographies. The International Journal of Artificial Organs, 2011. 34, 54-63.

34. X. Liu, J.Y. Lim, H.J. Donahue, R. Dhurjati, A.M. Mastro, E.A. Vogler. Influence of substratum surface chemistry/energy and topography on the human fetal osteoblastic cell line hFOB 1.19: Phenotypic and genotypic responses observed in vitro. Biomaterials, 2007. 28, 4535-4550.

35. M.J. Dalby, S. Childs, M.O. Riehle, H.J.H. Johnstone, S. Affrossman, A.S.G. Curtis. Fibroblast reaction to island topography: changes in cytoskeleton and morphology with time. Biomaterials, 2003. 24, 927-935.

36. M.J. Dalby. Topographically induced direct cell mechanotransduction. This issue contains a special section on Effects of Mechanical Forces Engineering Reactions at the Cellular Level, 2005. 27, 730-742.

37. C.G. Galbraith, K.M. Yamada, M.P. Sheetz. The relationship between force and focal complex development. The Journal of Cell Biology, 2002. 25, 695-705. 
38. N.Q. Balaban, U.S. Schwarz, D. Riveline, P. Goichberg, G. Tzur, I. Sabanay, D. Mahalu, S. Safran, A. Bershadsky, L. Addadi, B. Geiger. Force and focal adhesion assembly: a close relationship studied using elastic micropatterned substrates. Nature Cell Biology, 2001. 3, 466-472.

39. D. Gugutkov, G. Altankov, J.C. Rodríguez Hernández, M. Monleón Pradas, M. Salmerón Sánchez. Fibronectin activity on substrates with controlled -OH density. Journal of Biomedical Materials Research Part A, 2010. 92A, 322-331.

40. G. Altankov, T. Groth. Reorganization of substratum-bound fibronectin on hydrophilic and hydrophobic materials is related to biocompatibility. Journal of Materials Science: Materials in Medicine, 1994. 5, 732-737.

41. G. Altankov, T. Groth. Fibronectin matrix formation and the biocompatibility of materials. Journal of Materials Science: Materials in Medicine, 1996. 7, 425-429.

42. R. Tzoneva, T. Groth, G. Altankov, D. Paul. Remodeling of fibrinogen by endothelial cells in dependence of fibronectin matrix assembly. Effect of substratum wettability. Journal of Materials Science: Materials in Medicine, 2002. 13, 12351244.

43. G. Altankov, F. Grinnell, T. Groth. Studies on the biocompatibility of materials: fibroblast reorganization of substratum-bound fibronectin on surfaces varying in wettability. Journal of Biomedical Materials Research, 1996. 30, 385-391.

44. I.C. Gonçalves, M.C.L. Martins, M.A. Barbosa, B.D. Ratner. Protein adsorption on 18-alkyl chains immobilized on hydroxyl-terminated self assembled monolayers. Biomaterials, 2005. 26, 3891-3899.

45. G. Altankov, T. Groth. Fibronectin matrix formation by human fibroblasts on surfaces varying in wettability. Journal of Biomaterials Science, Polymer Edition 1996. 8, 299-310. 



\title{
5. Surface mobility regulates cell adhesion and skeletal stem cells differentiation
}

\begin{abstract}
Summary
In this chapter fibronectin activity is shown to be extremely sensitive to subtle variations in polymer chemistry, and surface mobility is identified as a new physical parameter of the matrix able to regulate skeletal stem cell differentiation. A family of acrylic polymers with minimal differences in their chemical composition (the number of methyl groups in the lateral chain) provide materials of different stiffness and surface mobility, where protein adsorption is altered. On surfaces with similar fibronectin adsorption and distribution, initial cell adhesion and differentiation were regulated by surface mobility, which enhanced both cellular functions.
\end{abstract}

* Results presented in this chapter have been published in: Brizuela $N$, González-García C, Llopis V, Rodríguez-Hernández JC, Moratal D, Rico P, Salmerón-Sánchez M. Soft Matter, 2010, 6, 4748-55; and González-García C, Moratal D, Oreffo ROC, Dalby MJ, Salmerón-Sánchez M. Integrative Biology, 2012, 4, 531-539. 



\subsection{Introduction}

Mesenchymal or skeletal stem cells are able to differentiate along the stromal lineage to give rise to osteoblasts, chondrocytes and adipocytes through the application, typically, of chemical cues and specific factors [1-2]. There is also a wealth of emergent data about that mesenchymal or skeletal stem cells are highly sensitive to their environment and, when cultured on synthetic substrates, these cells respond to cues provided by chemistry, stiffness, surface topography and dimensionality (2D vs 3D), which are able to direct skeletal stem cell lineage differentiation [3-11].

Cell-material interactions occur through a layer of matrix proteins including fibronectin (FN), vitronectin, fibrinogen and laminin that interface living cells and synthetic surfaces [12-15]. The concentration, distribution, and motility of the adsorbed protein layer on a surface, plays a fundamental role in the biofunctionality of a synthetic material. Thus it may be possible to manipulate these parameters to augment the biological response of a cell to a substrate [16].

It is recognized that the mechanical properties of the matrix are known to influence cell behavior regardless the protein coating of the substrate. Differentiated cells such as fibroblasts, muscular VSMC cells, chondrocytes and neurons, cultured on rigid/stiff substrates, have been shown to develop micronsized focal adhesions connected by actin fibers. However, these focal adhesions structures are gradually lost as cells are grown on softer matrices, as obtained by, for example, changing the crosslinking density of gels [17-20]. There is evidence that cell spreading and motility are enhanced on stiff substrates in comparison to soft surfaces (which favors cell-cell interaction and leads to more dense cell aggregates) [21]. Furthermore, cell proliferation has been shown to be increased on stiff surfaces and, in the case of a rigidity gradient on the substrate, cells migrate to stiffer regions (durotaxis) [22-23]. 
Seminal work from Engler et al. provided the first evidence that matrix elasticity can direct stem cell lineage specification in the absence of soluble induction factors [4]. The authors showed stem cells expressed markers for neurogenic, myogenic or osteogenic lineages when cultured on substrates mimicking neural, muscle and bone stiffness respectively [3-4, 24-26]. However, the preparation of substrates with controlled rigidity often leads to small variations in substrate chemistry, as observed in changing the crosslinking ratio in a polyacrylamide gel $[4,18]$. In addition, some studies suggest that these changes in themselves lead to subtle variations in surface chemistry which alter protein adsorption that as a consequence alter cell behavior [27].

The current work investigates mesenchymal stem cell differentiation on a family of FN-coated polymers whose physical properties (stiffness and surface mobility) could be modulated by minute variations in material chemistry -the sequential addition of methyl groups in the side group of a vinyl chain. FN was adsorbed on the different substrates and its supramolecular organization characterized by AFM. FN adsorption, in terms of the surface density and conformation, was noted to not occur equally on each test substrate. Subtle variations in surface chemistry were noted and these led to a non-monotonical dependence of mesenchymal stem cell differentiation in response to the physical properties of the matrix. Our findings identify surface mobility as a key factor able to regulate skeletal stem cell differentiation with wider implications therein for the modulation and manipulation of stem, progenitor and adult populations in hard and soft tissue regeneration. 


\subsection{Materials and Methods}

\subsubsection{Preparation of films}

Polymer sheets were obtained by radical polymerization of a solution of the corresponding acrylic monomer; methyl (MA), ethyl (EA) and butyl acrylate (BA) (Sigma-Aldrich) using $0.2 \mathrm{wt} \%$ benzoin ( $98 \%$ pure, Scharlau) as a photoinitiator. After polymerization, low molecular-mass substances were extracted from the material by drying in vacuo at $60^{\circ} \mathrm{C}$. Then, each one of the synthesized polymers was dissolved in toluene at a concentration of $2 \mathrm{wt} \%$. Thin films were prepared by spin casting of the polymer solutions on $12 \mathrm{~mm}$ glass coverslips at $2000 \mathrm{rpm}$ for $30 \mathrm{~s}$. Samples were dried in vacuo at $60^{\circ} \mathrm{C}$ before further characterization.

\subsubsection{Characterization of films}

\section{Water contact Angle}

Surface wettability was characterized by measuring the water contact angle with a DataPhysics OCA 20 device. A drop of water of $10 \mu$ was employed. The measurements were performed per triplicate.

\section{Mechanical measurements}

Mechanical measurements were performed on a Perkin Elmer DMA device in the traction mode. The elastic modulus was recorded as a function of temperature; from $-50^{\circ} \mathrm{C}$ to $50^{\circ} \mathrm{C}$. Specimens were bars ca. $5 \times 8 \times 1 \mathrm{~mm}$.

\section{Atomic force microscopy}

Atomic force microscope was employed to analyze the surface of the substrates and the protein distribution on them. 
AFM experiments were performed using a Multimode AFM equipped with NanoScope IIla controller from Veeco (Manchester, UK) operating in tapping mode in air. The Nanoscope 5.30r2 software version was used. Si-cantilevers from Veeco (Manchester, UK) were used with force constant of $2.8 \mathrm{~N} / \mathrm{m}$ and resonance frequency of $75 \mathrm{kHz}$. The phase signal was set to zero at a frequency $5-10 \%$ lower than the resonance one. Drive amplitude was $600 \mathrm{mV}$ and the amplitude setpoint $A_{s p}$ was $1.8 \mathrm{~V}$. The ratio between the amplitude setpoint and the free amplitude $A_{s p} / A_{0}$ was kept equal to 0.8 .

Samples were analyzed in the AFM and height, phase and amplitude magnitudes were recorded simultaneously for each image.

\subsubsection{Protein adsorption}

The protein adsorption was characterized by the adsorbed surface density (by Western Blot) and its distribution and conformation on the different substrates (by AFM).

\section{Distribution and conformation}

Fibronectin from human plasma (Sigma) was adsorbed on the different substrates by immersing the material sheets in several FN solutions at concentrations of 2, 5, 20 and $50 \mu \mathrm{g} / \mathrm{ml}$ in PBS for 10min. After adsorption, samples were rinsed in PBS to eliminate the non-adsorbed protein. The remaining drops on the surface were dried by exposing the sample to a nitrogen flow for 2-3 min. AFM was performed in the tapping mode immediately after sample preparation. Height, phase and amplitude magnitude were recorded simultaneously for each image. 


\section{Protein quantification}

To quantify the amount of adsorbed fibronectin, the remaining protein in the supernatant was measured, i.e. the amount of protein that remained in solution without adsorbing on the material surface, as explained elsewhere [28]. Different aliquots of non-adsorbed protein on substrates were subjected to $5 \%$ SDS polyacrylamide gel electrophoresis (PAGE), using Laemmli buffer $2 x$ and denaturing standard conditions. Proteins were transferred to a positively charged polyvinylidene difluoride nylon membrane (GE Healthcare) using a semi-dry transfer cell system (Biorad), and blocked by immersion in $5 \%$ skimmed milk in PBS for $1 \mathrm{~h}$ at room temperature. The blot was incubated with anti-human fibronectin polyclonal antibody (developed in rabbit, Sigma) (1:500) in PBS and washed three times (10 min each) with PBS containing 0.1\% Tween-20 and $2 \%$ skimmed milk. The blot was subsequently incubated in horseradish peroxidase-conjugated donkey anti-rabbit immunoglobulin G (GE Healthcare) diluted 1:20000 in PBS containing TWEEN 20 and $2 \%$ milk ( $1 \mathrm{~h}$ at room temperature). The enhanced chemiluminescence detection system (GE Healthcare) was used according to the manufacturer's instructions prior to exposing the blot to X-ray film for $1 \mathrm{~min}$.

Image analysis of the western bands was done using in-house software developed under MATLAB R2009b (The MathWorks, Inc., Natick, MA, USA). All the western blotting bands were digitized using the same scanner (Epson Stylus Photo RX500, Seiko Epson Corpo., Nagano, Japan) and the same scan parameters: 8 bits gray scale image and $300 \mathrm{dpi}$. The digitized images were binarized using the Otsu method, which chooses the threshold that minimizes the intraclass variance of the thresholded black and white pixels, in order to create a mask that automatically selected the edge of each western blot band [29]. This mask was applied to a negative version of the original scanned picture providing a resulting image which contained only the western bands. The last step of the process consisted of adding all the pixels that conformed each band correctly weighted by their intensity level. 


\subsubsection{Cell culture}

Human bone marrow stromal cells were obtained from hematologically normal patients undergoing routine hip-replacement surgery as described previously with full ethical approval and patient consent [30]. Skeletal/mesenchymal stem cell populations were enriched from the bone marrow stromal cell population with Stro-1 selection using magnetic activated cells sorting (MACS) as previously detailed [31]. Stro-1 has been used as a stringent marker for enhancing the most primitive multipotent population of the bone marrow [32-35]. Thus, these cells can be used at very low passage preventing phenotypical drift due to prolonged culture/excessive passaging. Prior to seeding on FN-coated substrates, STRO-1+ cells were cultured in 75 $\mathrm{cm}^{2}$ tissue culture flasks and cells were maintained in basal medium (aMEM supplemented with $10 \%$ foetal bovine serum and $2 \%$ antibiotics) at $37^{\circ} \mathrm{C}$. All cells used in this study were form passage 3 or lower.

Sample disks (12 $\mathrm{mm}$ diameter) previously sterilized in UV for $1 \mathrm{~h}$ and placed in a 24-well tissue culture plate were hydrated with PBS and coated with FN 20 $\mu \mathrm{g} / \mathrm{mL}$ ( $1 \mathrm{~h}$ at room temperature). Then, $1 \times 10^{4}$ cells were placed onto each substrate and the experiments were carried out in aMEM medium in serum-free conditions at $37^{\circ} \mathrm{C}$ in a humidified atmosphere under $5 \% \mathrm{CO}_{2}$ for $2 \mathrm{~h}$, in order to study the initial adhesion on FN coated substrates. After that, the medium was changed to aMEM medium with $10 \%$ FBS, in order to provide the necessary nutrients during the incubation time, and the substrates were incubated at $37^{\circ} \mathrm{C}$ for different times: 3 days for cell adhesion, 1 day to detect the phosphorylation of Runx2, and 21 days for osteocalcin (OCN) and osteopontin (OPN) expression. The medium was replaced after one culture day in all experiments, and it was changed twice weekly in experiments of 21 days. Each experiment was performed in triplicate. 


\subsubsection{Cell adhesion}

After 3 days, MSCs were washed in phosphate buffered saline (PBS) and fixed with $4 \%$ formaldehyde (Fisher) with $2 \%$ sucrose in phosphate-buffered saline (PBS), at $37^{\circ} \mathrm{C}$ for 15 minutes. Afterwards, the samples were rinsed with PBS and a permeabilising buffer (10.3 g sucrose, $0.292 \mathrm{~g} \mathrm{NaCl}, 0.06 \mathrm{~g} \mathrm{MgCl}$, $0.476 \mathrm{~g}$ Hepes buffer, $0.5 \mathrm{ml}$ Triton $\mathrm{X}$, in $100 \mathrm{ml} \mathrm{PBS}, \mathrm{pH}$ 7.2) was added at 4 ${ }^{\circ} \mathrm{C}$ for 5 minutes. The samples were saturated then with $1 \%$ BSA/DPBS at 37 ${ }^{\circ} \mathrm{C}$ for 5 minutes. Subsequently they were incubated a $37^{\circ} \mathrm{C}$ for $1 \mathrm{~h}$ with primary antibody against vinculin (monoclonal mouse antibody, Sigma, 1:150) and with rhodamine-conjugated phalloidin (Invitrogen, 1:50) to stain actin, in 1\% BSA in PBS. After three washes with PBS/0.5\% Tween 20, a biotinylated anti-mouse secondary antibody (Vector Laboratories, 1:50) was incubated for 60 minutes at $37^{\circ} \mathrm{C}$, followed by fluorescein streptavidin tertiary label (Vector Laboratories, 1:50) for 30 minutes at $4^{\circ} \mathrm{C}$. Finally the samples were rinsed in PBS three times before mounted in Vectashield containing DAPI staining (Vector Laboratories). An Axiovert 200M fluorescence microscope was used for imaging.

\subsubsection{MSC differentiation}

After different culture times, MSCs were washed in phosphate buffered saline (PBS) and fixed with $4 \%$ formaldehyde (Fisher) with $2 \%$ sucrose in phosphate-buffered saline (PBS), at $37^{\circ} \mathrm{C}$ for 15 minutes. Afterwards, the samples were rinsed with PBS and a permeabilising buffer (10.3 g sucrose, $0.292 \mathrm{~g} \mathrm{NaCl}, 0.06 \mathrm{~g} \mathrm{MgCl} 2,0.476 \mathrm{~g}$ Hepes buffer, $0.5 \mathrm{ml}$ Triton X, in $100 \mathrm{ml}$ PBS, pH 7.2) was added at $4{ }^{\circ} \mathrm{C}$ for 5 minutes. The samples were saturated then with $1 \%$ BSA/DPBS at $37^{\circ} \mathrm{C}$ for 5 minutes. Subsequently they were incubated a $37^{\circ} \mathrm{C}$ for $1 \mathrm{~h}$ with primary antibody against phosphoRunx2 (rabbit polyclonal, Abgent, 1:100), or OPN (mouse monoclonal, Autogen Bioclear, $1: 50$ ), or OCN (mouse monoclonal, Autogen Bioclear, 1:50), all of them dissolved in 1\% BSA in PBS. After three washes with PBS/0.5\% Tween 20, the appropriate biotinylated anti-mouse or anti-rabbit secondary antibody (Vector 
Laboratories, 1:50) was incubated for 60 minutes at $37^{\circ} \mathrm{C}$, followed by fluorescein streptavidin tertiary label (Vector Laboratories, 1:50) for 30 minutes at $4{ }^{\circ} \mathrm{C}$. Finally the samples were rinsed in PBS three times before mounted in Vectashield containing DAPI staining (Vector Laboratories). Secondary and tertiary antibody controls were performed for these cells. An Axiovert 200M fluorescence microscope was used for imaging.

\subsubsection{Image analysis}

\section{Focal adhesion plaques}

The size distribution of the focal plaques was determined through a severalstep image analysis including a contour delineation of the cell. For a perfect segmentation of the cell, (i) images showing the actin cytoskeleton were grayscaled and equalized. (ii) The cell was then detected (segmented). Since the cytoskeleton differed greatly in contrast from the background image, a gradient-magnitude method (Sobel) [36-38] was applied to the image and once the gradient image was calculated, a binary mask was created containing the segmented cytoskeleton. (iii) Compared to the original image, the binary gradient mask showed gaps in the lines surrounding the cell (the outline of the object of interest was not completely delineated). These linear gaps disappeared when the Sobel image was dilated using linear structuring elements (a vertical structuring element followed by a horizontal one), obtaining a clear and perfect contour detection of the cell. Once the cell was perfectly segmented, the obtained binary mask was then applied to the image obtained in the red channel for vinculin. This permitted the focus of the attention on the cell and the focal adhesions, as any other object in the image was virtually erased. This new image was then binarized through Otsu's method and size-filtered to avoid any extra small particles in the image that did not represent focal plaques of the size to be determined [29]. Once the sizes of the focal contacts were determined, a size distribution was easily obtained. 


\section{Differentiation markers (OPN, OCN, phosphoRunx2)}

Images were firstly equalized, providing an output grayscale image with its intensity values evenly distributed throughout the intensity range. Afterwards, they were segmented into 5 different classes by means of Otsu's multiple thresholding method [29]. Each class was then size-filtered using an opening morphological operator to eliminate remaining isolated pixels and the existing gaps were filled using an erosion morphological operator followed by a dilation one, using both a diamond structuring element of size 3 . The calculus of the intensity and the area covered by the 3 most brightest classes of the 5 different ones into which the image was segmented previously was then easily performed.

\subsubsection{Statistics}

All experiments were performed at least three times, in triplicate, unless otherwise noted. Data are reported as mean \pm standard error. Results were analyzed by one-way ANOVA using SYSTAT 8.0 (SPSS). If treatment level differences were determined to be significant, pair-wise comparisons were performed using a Tukey post hoc test. A 95\% confidence level was considered significant. 


\subsection{Results and discussion}

\subsubsection{Material properties}

Substrates investigated in this work are a set of acrylic polymers which consist of a vinyl backbone chain with the side groups $-\mathrm{COO}\left(\mathrm{CH}_{2}\right)_{x} \mathrm{H}$, where $x=1,2,4$ (Figure 5.1a). Thus, the only difference in their molecular structure is the number of methyl groups in the lateral chain. Surface wettability for these substrates increases $10^{\circ}$ from PMA to the rest of the substrates, where remained approximately constant at $80^{\circ}$ (Figure 5.1b), in agreement with the similar surface chemistry. In contrast, the elastic moduli (matrix elasticity), as measured at $37^{\circ} \mathrm{C}$ (the physiological temperature at which cell cultures were performed), was observed to decrease monotonically as the number of methyl groups in the side chain increased, without modifying any other functionality of the system (Figure 5.1c). Similarly, the glass transition temperature of the system, a dynamic property that accounts for the mobility of the polymer chains, decreased from $10{ }^{\circ} \mathrm{C}$ to $-50^{\circ} \mathrm{C}$ as number of carbons in the lateral chain increases (Figure 5.1d). 
a)

$$
\begin{aligned}
& \left(\mathrm{CH}_{2}-\mathrm{CH}\right)_{\mathrm{n}} \\
& \quad \mathrm{C} / \mathrm{O}-\overline{\mathrm{CH}}_{3}^{\mathrm{C}-1}
\end{aligned}
$$

Poly(methyl acrylate), PMA

$$
\begin{aligned}
& \left.+\mathrm{CH}_{2}-\mathrm{CH}\right)_{n} \\
& \quad \mathrm{C} O \frac{\text { \# of } \mathrm{C}-2}{\mathrm{CH}_{2} \mathrm{CH}_{3}}
\end{aligned}
$$

Poly(ethyl acrylate), PEA

$$
\begin{aligned}
& \left.+\mathrm{CH}_{2}-\mathrm{CH}\right)_{\mathrm{n}} \\
& \quad \mathrm{O} / \mathrm{C}-\frac{\text { \# of } \mathrm{C}-4}{\mathrm{CH}_{2} \mathrm{CH}_{2} \mathrm{CH}_{2} \mathrm{CH}_{3}}
\end{aligned}
$$

Poly(butyl acrylate), PBA
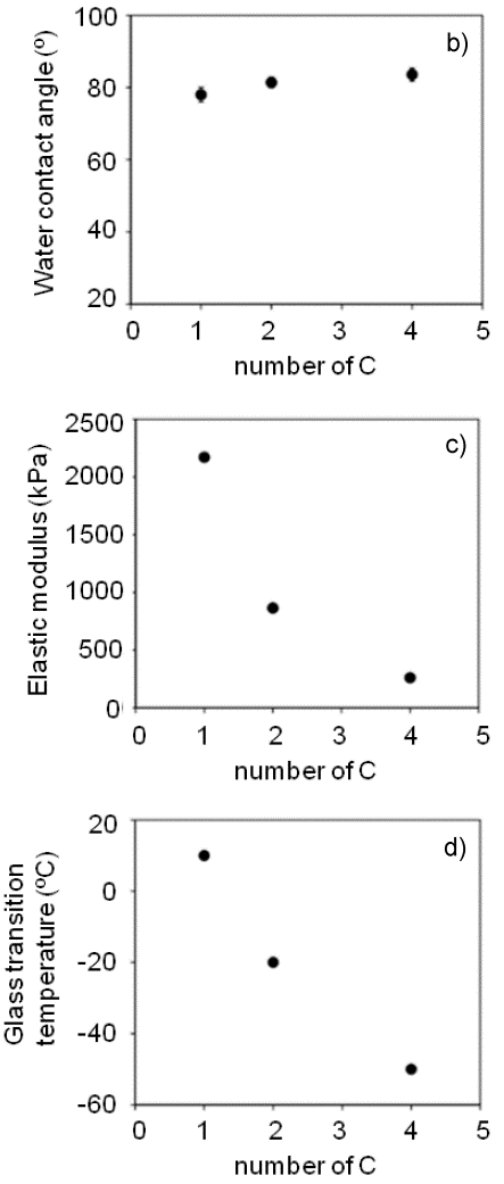

Figure 5.1 Properties of the material substrates. a) Chemical structure, b) water contact angle, c) elastic modulus at $37^{\circ} \mathrm{C}$, and d) glass transition temperature of the different substrates as a function of the length of the side group (number of C): PMA (1), PEA (2) and PBA (4).

The glass transition temperature $\left(T_{g}\right)$ is related to the mobility of the polymer chains, which is frozen at temperatures below the glass transition and increases dramatically at temperatures above $\mathrm{T}_{\mathrm{g}}$ [39]. More specifically, it has been recently shown that surface layer mobility is enhanced as the glass transition temperature of the films decrease [40]. In this family of polymers, the surface mobility is higher as the length of the lateral chain increases, since the glass 
transition temperature, i.e. the energy required for the polymer chains begin to acquire mobility, diminishes as the number of carbons increases (Figure 5.1d). It is important to remark here that surface mobility, as accounted by $T_{g}$, is a magnitude whose physical origin is independent of the mechanical modulus of the material: the mobility of the polymer chains is higher, at e.g. $37^{\circ} \mathrm{C}$, as lower is the $T_{g}$ of the sample, and while mechanical response involves the deformation of the substrate, surface mobility occurs regardless the mechanical actions performed on the substrate. The adsorbed proteins are able to sense surface mobility but remain unaffected by the mechanical properties of the surface, since proteins are not able to deform the substrate on which are adsorbed.

The topography of the surfaces was examined by AFM prior to protein adsorption. Similar roughness parameters were obtained regardless of the polymer composition (arithmetic average of the height deviations from the center plane, $\mathrm{Ra}=20 \mathrm{~nm}$ and standard deviation of the height values, Rms=25 $\mathrm{nm}$ ). The obtained films are not porous and are approximately $500 \mathrm{~nm}$ thick. In addition, in order to check the stability of the films, the surface of the materials was also scanned after immersion in PBS (i.e. without FN) and no significant modification in roughness was found. Therefore, this family of materials provides a system with minimal variations in surface chemistry, similar wettability and qualitatively different mechanical properties (the stiffness accounted for by the elastic modulus) and surface mobility (by the glass transition temperature) (Figure 5.1).

\subsubsection{Protein adsorption}

The amount of FN adsorbed on the different surfaces was quantified by western blot. For that, the amount of protein present in the supernatant after adsorption on the material surface was analyzed. A calibration curve was built by loading gels with known amounts of $\mathrm{FN}$ and the resulting bands quantified by image analysis making use of the Otsu's algorithm to systematically identify the 
band borders [29]. Figure 5.2 shows the results of the experiment on the different polymer substrates after adsorption from a FN solution of concentration $20 \mu \mathrm{g} / \mathrm{ml}$ for $2 \mathrm{~h}$. There is no significant difference among the amount of adsorbed FN on each substrate, which remains constant with a surface density of approximately $450 \mathrm{ng} / \mathrm{cm}^{2}$.

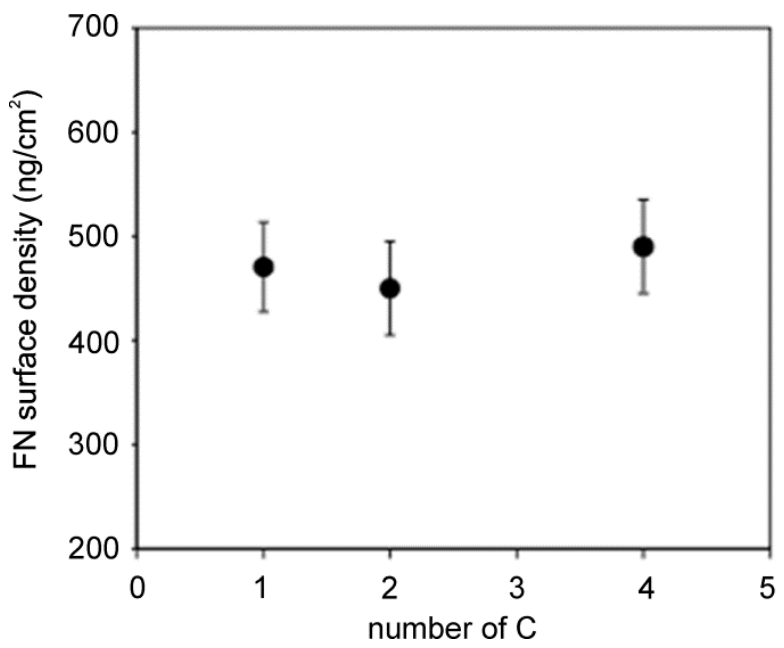

Figure 5.2 Fibronectin surface density on material surfaces as a function of the length of the side group (number of C): PMA (1), PEA (2) and PBA (4).

Figure 5.3 shows AFM phase images of the adsorbed FN on the different substrates from protein solutions of different concentrations (as indicated in the figure) for $10 \mathrm{~min}$. FN organization and distribution on the surface depends, for each substrate, on the concentration of the initial protein solution from which the protein is adsorbed. The lowest concentration $(2 \mu \mathrm{g} / \mathrm{ml})$ results in isolated globular FN molecules homogeneously distributed on the material for the three substrates. For a concentration of $5 \mu \mathrm{g} / \mathrm{ml}$ (Figure 5.3) globular protein molecules are still observed on PMA, but with higher density. However, the formation of an incipient network is already observed on PEA and a well interconnected one is observed on PBA. Protein adsorption from a solution of concentration $20 \mu \mathrm{g} / \mathrm{ml}$ gives rise to the formation of FN networks on PEA and PBA but not on PMA. Further increase of the concentration of the protein 
solution $(50 \mu \mathrm{g} / \mathrm{ml})$ gives rise to denser FN networks on PEA and PBA but only non-connected molecules remain on PMA.

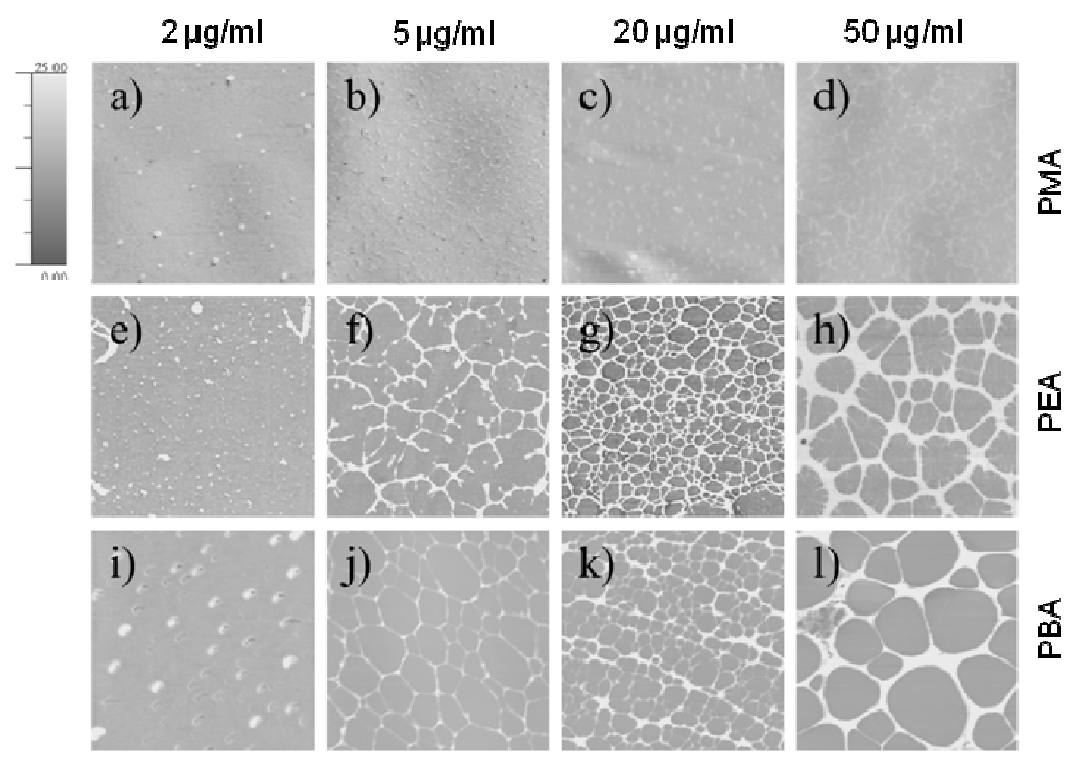

Figure 5.3 The Fibronectin distribution on the different substrates as observed by the phase magnitude in AFM after adsorption from solutions of different concentrations.

Figure 5.4 shows protein conformation and distribution at different magnifications (from $5 \mu \mathrm{m}$ to $500 \mathrm{~nm}$ window) after adsorption on the different substrates from a $20 \mu \mathrm{g} / \mathrm{ml}$ protein solution, which is the concentration typically employed when coating a substrate with the protein for cell culture purposes [41-42]. Upon adsorption, FN organization into networks takes place on PEA $(x=2)$ and PBA $(x=4)$ but not on PMA $(x=1)$. Only dispersed FN molecules are observed on the PMA substrate as the arrows in Figure 5.4 point out. 


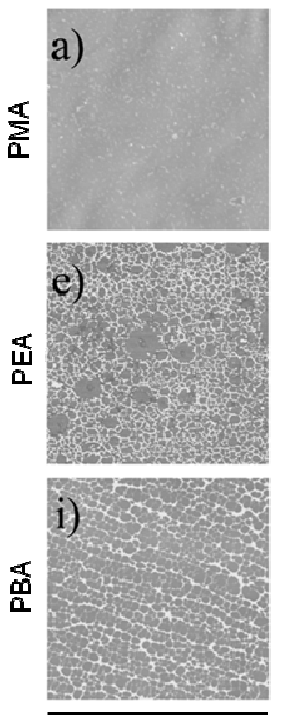

$5 \mu \mathrm{m}$
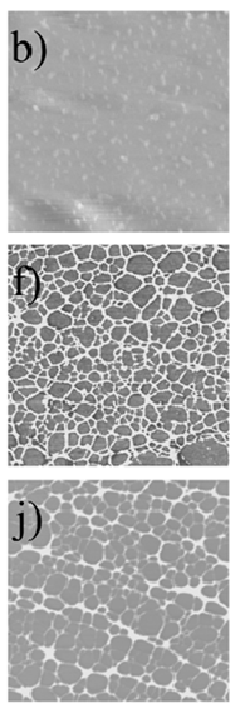

$2 \mu \mathrm{m}$
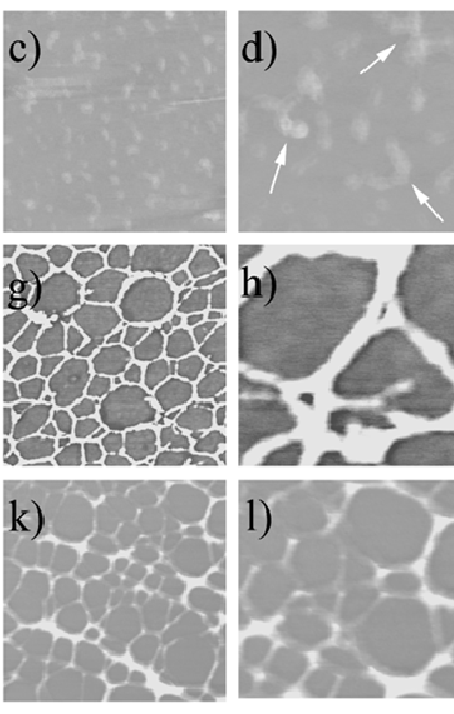

$1 \mu \mathrm{m}$

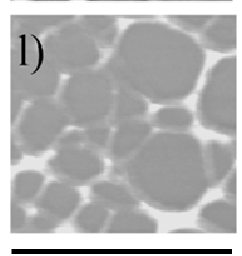

$500 \mathrm{~nm}$

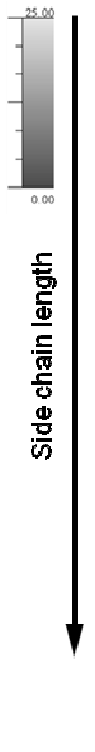

Figure 5.4 The distribution of fibronectin adsorbed on the different substrates from a solution of $20 \mu \mathrm{g} / \mathrm{ml}$, as observed by the phase magnitude in AFM at different magnifications.

That is to say, the distribution and conformation of the adsorbed FN, which determines its biological activity, shows some variations among the substrates. PEA is a well studied polymer which is known to trigger FN organization upon adsorption, leading to a so-called substrate induced fibronectin fibrillogenesis in absence of cells [28, 43-44]. The dynamics of the assembly process for the FN network on PEA was followed by AFM, and the resulting supramolecular network has shown to be biologically active, driving cell adhesion, focal adhesion formation and matrix deposition as well as enhanced myoblast differentiation [43-45]. In this study, Figure 5.3 shows that to include two additional methyl groups on the side chain of the polymer to obtain PBA, does also lead to the organization of $F N$ into networks on the substrate but with a different dynamic. FN adsorption from solutions of increasing composition leads to the formation of a well-developed protein network at lower concentrations of the solution, as the number of methyl groups in the side chain of the polymer 
increases. The glass transition temperature of PBA is $30^{\circ} \mathrm{C}$ below that of PEA (Figure 5.1d), which means that surface mobility is enhanced on PBA. This property can be related to the fact that the organization of FN takes place with faster dynamics on PBA than PEA, i.e., from lower concentrations of the adsorbing FN solution on PBA than on PEA. That is to say, well interconnected FN fibrils are found on PEA after adsorption from $20 \mu \mathrm{g} / \mathrm{ml}$ solution and on PBA after adsorption from $5 \mu \mathrm{g} / \mathrm{ml}$ solution. Nevertheless, similar supramolecular organization of the FN protein is found on PEA and PBA after adsorption from a solution of concentration $20 \mu \mathrm{g} / \mathrm{ml}$ (the one used to investigate the cell-material interaction) irrespective of the small differences in material chemistry and, consequently, independently of physical properties of these matrices such as either stiffness or surface mobility. By contrast, only globular FN molecules are distributed across the PMA surface, which supports the idea that minute variations in polymer chemistry alter FN conformation during adsorption [27]. These data show the importance of considering the adsorbed protein layer between surface and cell before discussing the influence of any physical property on cell response.

Protein adsorption on this family of substrates occurs in such a way that allows studying two different phenomena at the cell-material interface. On the one hand, comparing the PMA with the rest of substrates, where similar amount of $\mathrm{FN}$ is adsorbed but with different distribution, differences in cell response cannot be attributed to the effect of matrix physical properties, since differences in FN activity are found. On the other hand, comparing PEA and PBA substrates allows one to focus on the effects of matrix physical properties (stiffness and surface mobility) on cell behavior, after discarding effects purely related to the organization of FN at the cell-material interface [46].

It is important to note that the elastic modulus measured for the different substrates is higher than $500 \mathrm{kPa}$ (Figure 5.1c), which is higher than the stiffness of the bone natural microenvironment. Since cells must deform the substrate to sense it, and taking into account the range of forces cells can exert 
(which range from 1 to $5 \mathrm{nN} / \mu^{2}$ ) [47-48], it would appear that cells are not able to deform so rigid substrates $[4,49-50]$ and, consequently, the family of materials investigated must be sensed as simply rigid substrates by cells. Moreover, it is convenient to remark here that the elastic modulus was measured in the traction mode for the bulk polymers and the substrates employed consist on polymer thin films (500 nm thickness), obtained by spin casting of the polymer solutions on glass coverslides. Since it has been shown that cells are able to sense the stiffness of the underlying substrate up to $1 \mu \mathrm{m}$ depth, the underlying glass makes our substrates still stiffer from cells perspective. [51-52]. This would indicate that changes observed in cell response are not linked to stiffness of the substrate [53]; thus surface mobility is suggested as the determining factor in the cellular response.

\subsubsection{Cell adhesion and skeletal stem cell differentiation}

Mesenchymal stem cells respond dramatically in both morphology and lineage to physical characteristics of the matrix presented, including surface chemistry [9], nanotopography [6], and stiffness [4] even in the absence of soluble factors in the media $[4,6]$. In this work, the initial cell adhesion of skeletal mesenchymal stem cells and its differentiation to cell bone lineage, due to the only influence of the physical properties of the substrates, were investigated.

\section{Cell adhesion}

The initial cell adhesion of human skeletal mesenchymal stem cells (hMSCs) was evaluated after 3 days of culture on the FN-coated surfaces to ensure a good adhesion on the surface and still be individual cells [54], which allow focusing on the cell-material interaction rather than cell-cell interaction. It is important to note that the initial cell-material interaction occurred in serum-free medium, thus the initial cell contact is only via the initial layer of adsorbed $\mathrm{FN}$ on the material surfaces. Figure 5.5 demonstrates the overall morphology of cells 
following staining for actin. Cells were noted to present prominent actin fibers terminating at well-developed focal adhesion complexes, as depicted in first row (Figure 5.5) for vinculin.
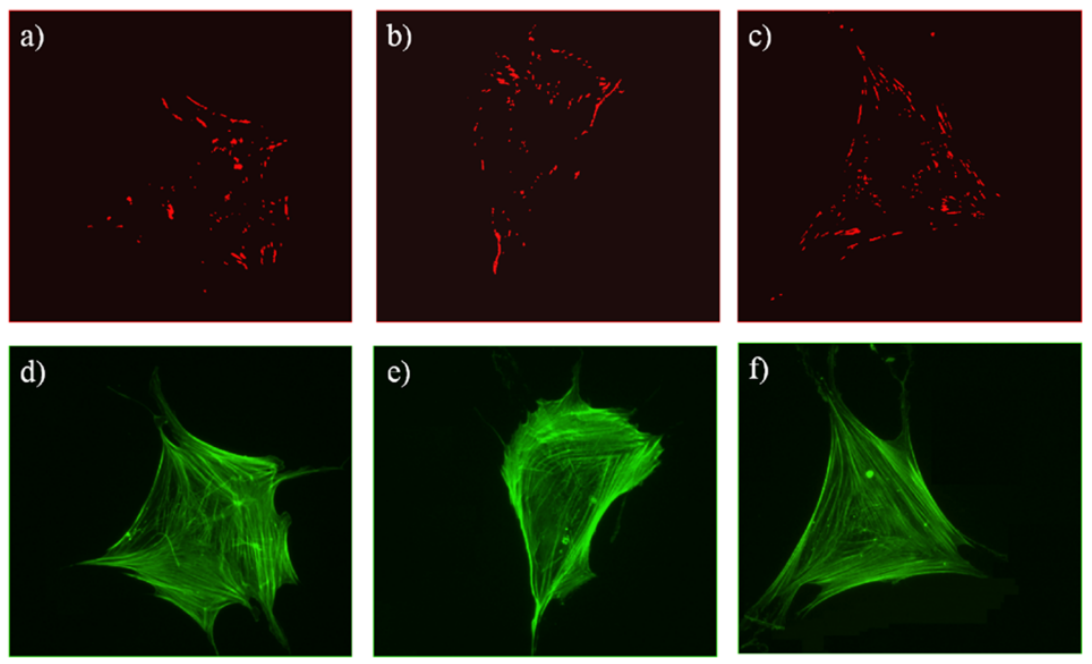

Figure 5.5 Focal adhesion formation (vinculin, top) and actin cytoskeleton organization after 3 days on FN coated surfaces for cells on the different surfaces: PMA (a,d), PEA $(\mathrm{b}, \mathrm{e})$ and PBA $(\mathrm{c}, \mathrm{f})$.

The area of the focal plaques was quantified by image analysis (of vinculin images) for several $(n>10)$ cells on the different substrates. The sequential process to delimitate focal adhesion plaques from the original image (described in the experimental section) and the focal plaques frequency distribution on the different substrates are presented in Figure 5.6. The distribution of focal plaques was similar for cells on the three surfaces, with a higher fraction (40\%) of the smallest adhesions $\left(<1 \mu \mathrm{m}^{2}\right)$ that decreased monotonically up to $6 \mu \mathrm{m}^{2}$ (Figure 5.6b).

Focal adhesions play an essential role in cellular mechanosensing, including mechanochemical signal conversion and integrin clustering and strengthening of integrin-cytoskeleton linkages [55-56]. The total force transmitted by focal adhesions has been suggested to be proportional to their area [47]. The lack of 
differences found for the cytoskeleton developments in agreement with the similar size distribution of focal adhesion plaques on these three surfaces.

In contrast, there are significant differences for the distribution of the absolute number of focal contacts per cell: Figure 5.6c demonstrates higher numbers of focal contacts of 1,2 and $3 \mu \mathrm{m}^{2}$ on the substrate with the longest side group $(x=4)$. This is more clearly observed in Figure 5.6d illustrating the total number of focal adhesions per cell which was qualitatively higher on $x=4$.
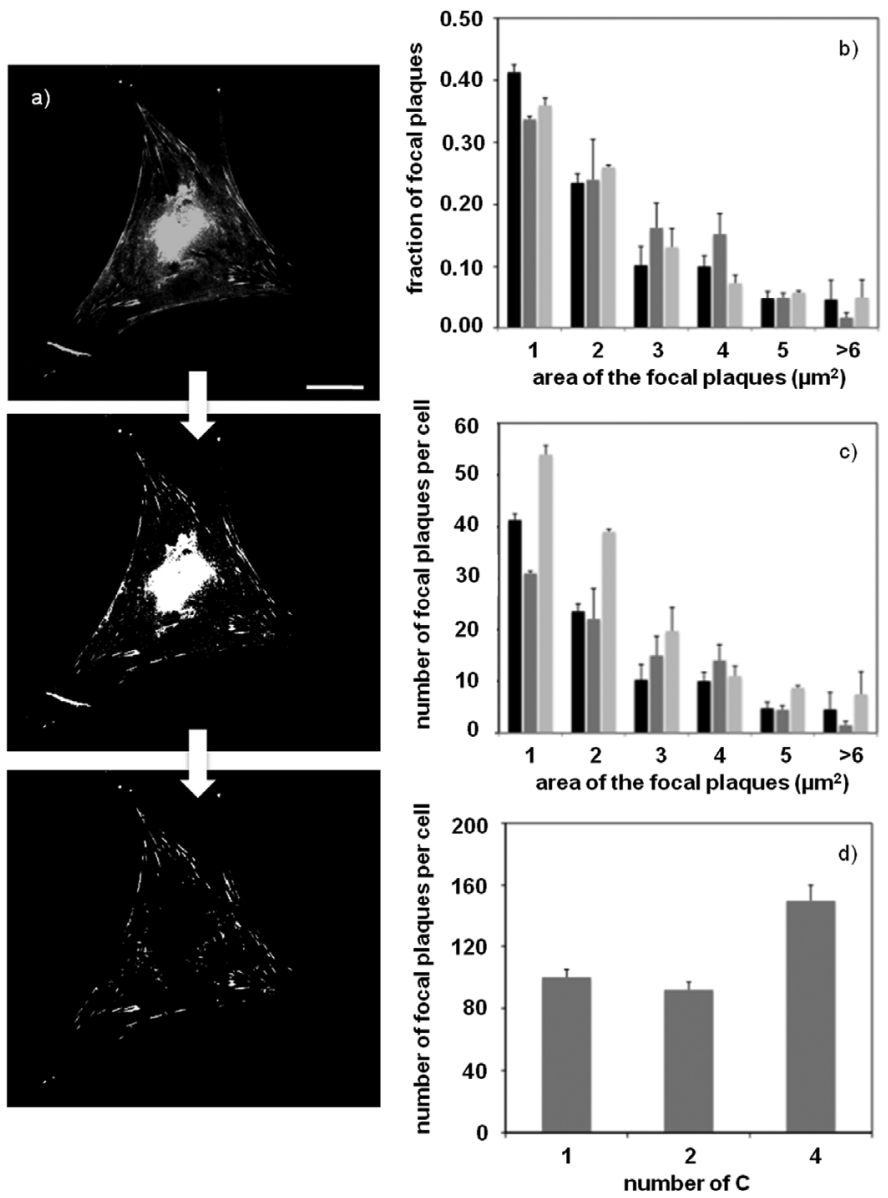

Figure 5.6 Image analysis of focal adhesions. a) The sequential process to delimitate focal adhesion plaques from the original image (vinculin) is show for one cell. b) Size 
distribution of the focal plaques and c) distribution of the number of focal plaques per cell as a function of the area of the focal plaques on the different substrates. d) Total number of focal plaques per cell on the different substrates (number of $\mathrm{C}$ ).

Since cells are not able to detect differences in substrate stiffness -in materials with elastic modulus of the order of magnitude of this family of polymers (higher than $500 \mathrm{kPa}$, Figure 5.1c)-, the initial cell adhesion of MSCs was regulated by the surface mobility on substrates on which similar fibronectin activity was found ( $x=2$ and 4 ). Comparing both materials, cell adhesion was enhanced on the substrate of higher surface mobility.

We have recently investigated the cell adhesion of MC3T3 osteoblast-like cells on this family of polymers. Comparing the substrates with similar FN activity, a size distribution with higher focal adhesion plaques was found on PEA ( $x=2)$, the material with lower surface mobility. That is to say, for these cells, the initial cell adhesion -assessed by the size of focal plaques instead the number of focal adhesions- was enhanced on the surface with lower mobility. However, it is important to mark that both studies were performed with different kind of cells and the cell adhesion was characterized by focusing on different parameters of the focal adhesions.

\section{$\underline{\text { Skeletal stem cell differentiation }}$}

The effect of the subtle variations in surface chemistry on mesenchymal or skeletal stem cell differentiation was examined in basal media devoid of any supplements. Taking into account the range of stiffness measured on these materials, differentiation along the osteoblastic lineage was determined. The immunofluorescence staining of secreted matrix-associated proteins (OCN and OPN) were used as markers of osteoblastic differentiation [6-7, 54]. A methodology to quantify imunofluorescence images for osteogenic markers was developed (see details in the experimental section, page 145) and is shown in Figure 5.7 for osteocalcin (OCN) secretion on one of the surfaces. 

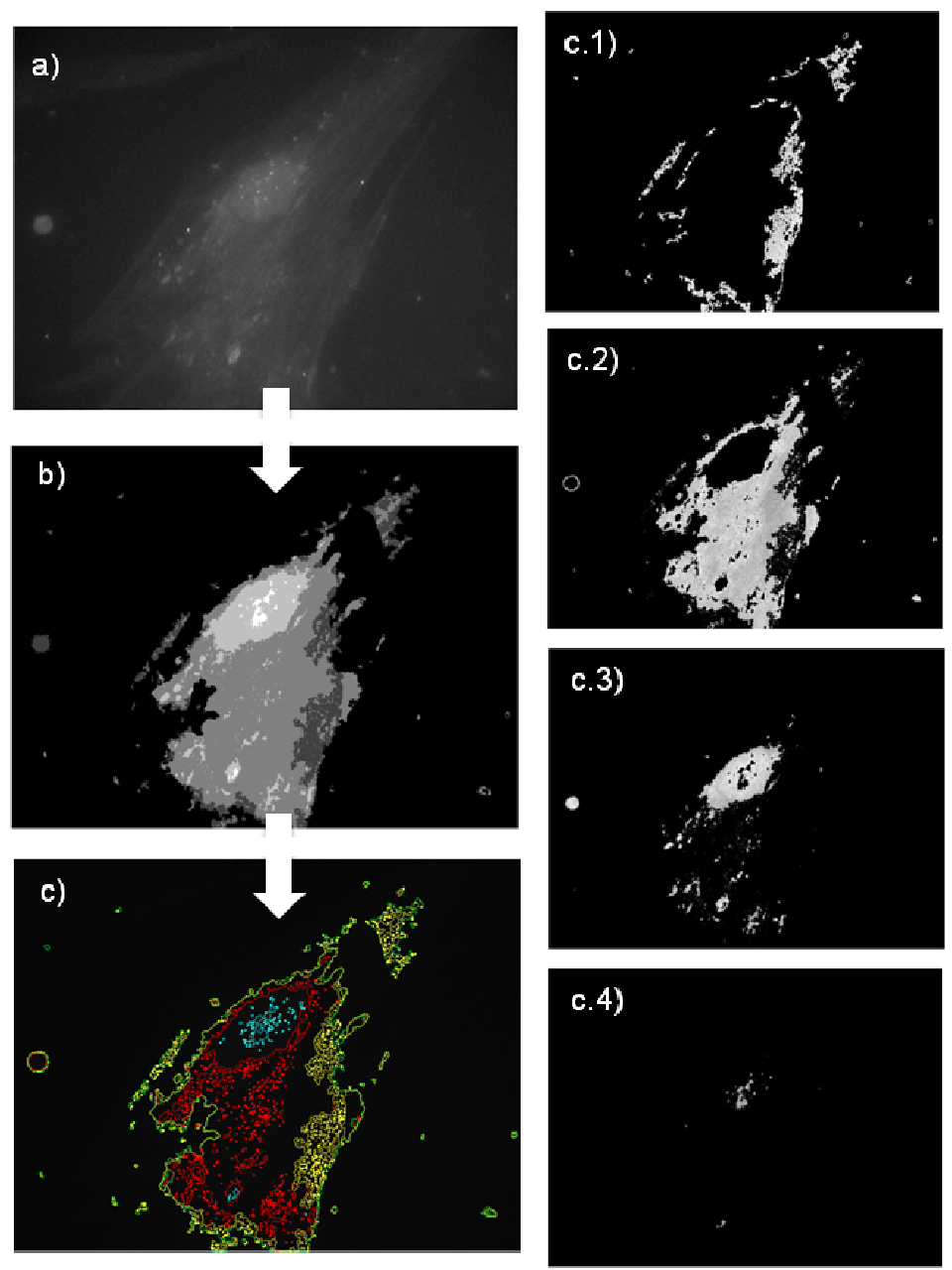

Figure 5.7 Image analysis for quantification of osteoblastic markers (osteocalcin, osteopontin and Runx2). The figure shows the sequential process of the analysis of OCN secretion for one substrate.

Figure 5.8 shows representative images for OCN expression on the different substrates examined. Quantification of the images shows non-monotonical dependence for OCN expression as the number of carbons increases in the side group of the substrates. Thus, OCN was upregulated on PMA $(x=1)$ and PBA $(x=4)$, while lower expression was observed on PEA $(x=2)$. 

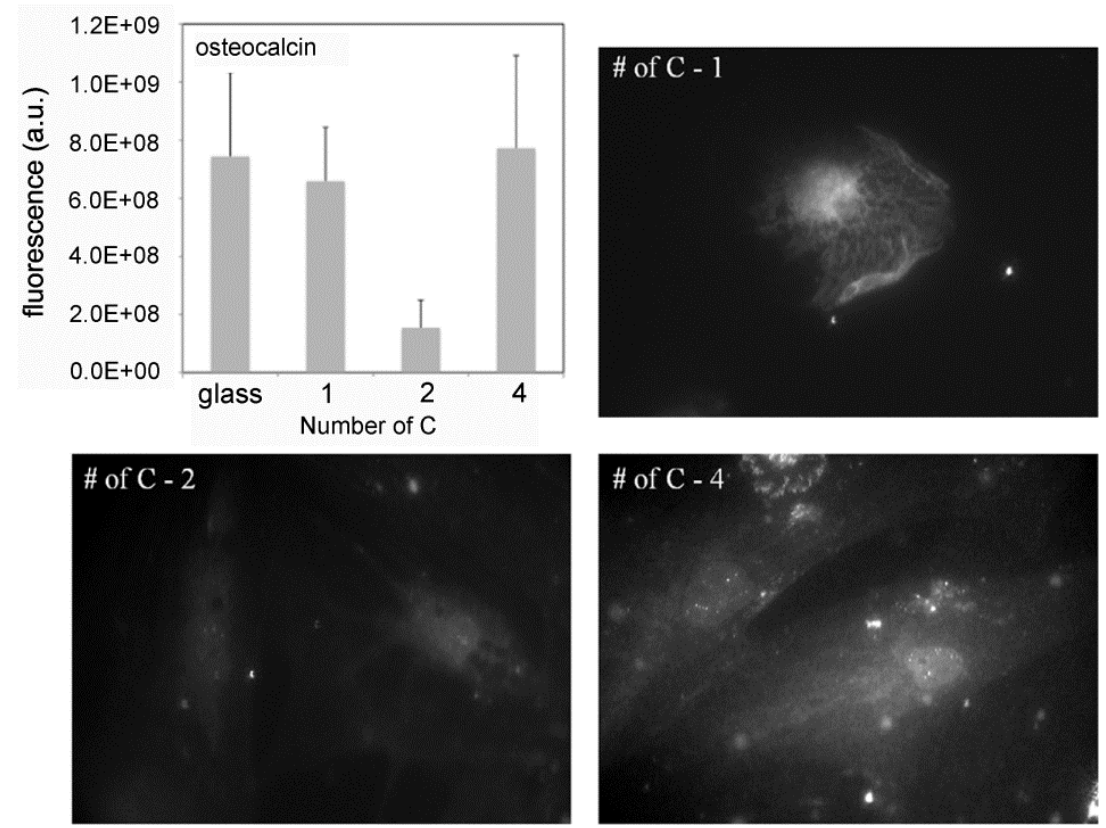

Figure 5.8 Osteocalcin staining of osteoprogenitors after 21 days of culture on the different surfaces containing increasing number of carbons in the side group, PMA (1), PEA (2) and PBA (4). The graph shows quantification from images as described previously in experimental section and Figure 5.7

The elastic modulus was noted to decrease and surface mobility increase monotonically as the length of the side groups increased ( $x$ from 1 to 4 ). Thus these data shows that OCN expression depends non-monotonically on physical properties of the matrix for this family of $\mathrm{FN}$-coated surfaces. Similar results were observed for osteopontin (OPN) secretion on the different substrates (Figure 5.9). 

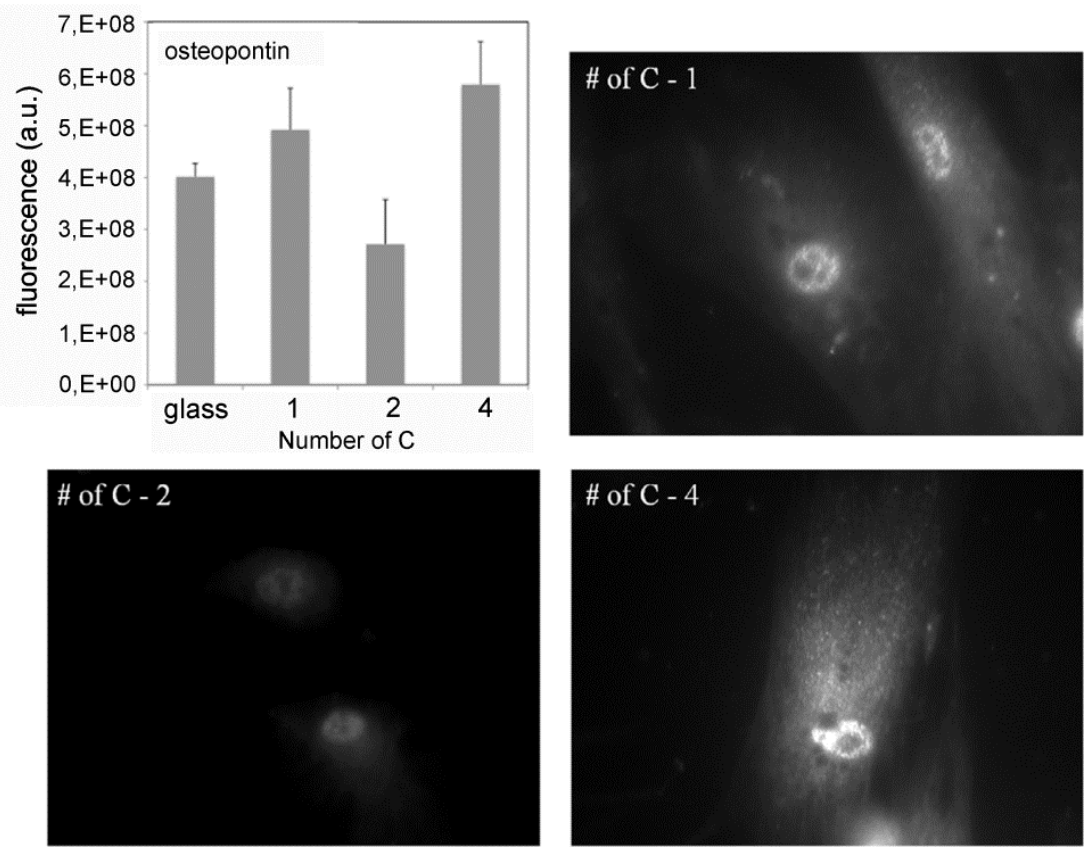

Figure 5.9 Osteopontin staining of osteoprogenitors after 21 days of culture on the different surfaces containing increasing number of carbons in the side group, PMA (1), PEA (2) and PBA (4). The graph shows quantification from images as described previously in experimental section and Figure 5.7

In contrast, the dependence of the phosphorylation of Runx2 was upregulated for cells on PBA $(x=4)$, although no significant differences were found between PMA $(x=1)$ and PEA $(x=2)$ (Figure 5.10). In all cases, glass was included as a control surface. 

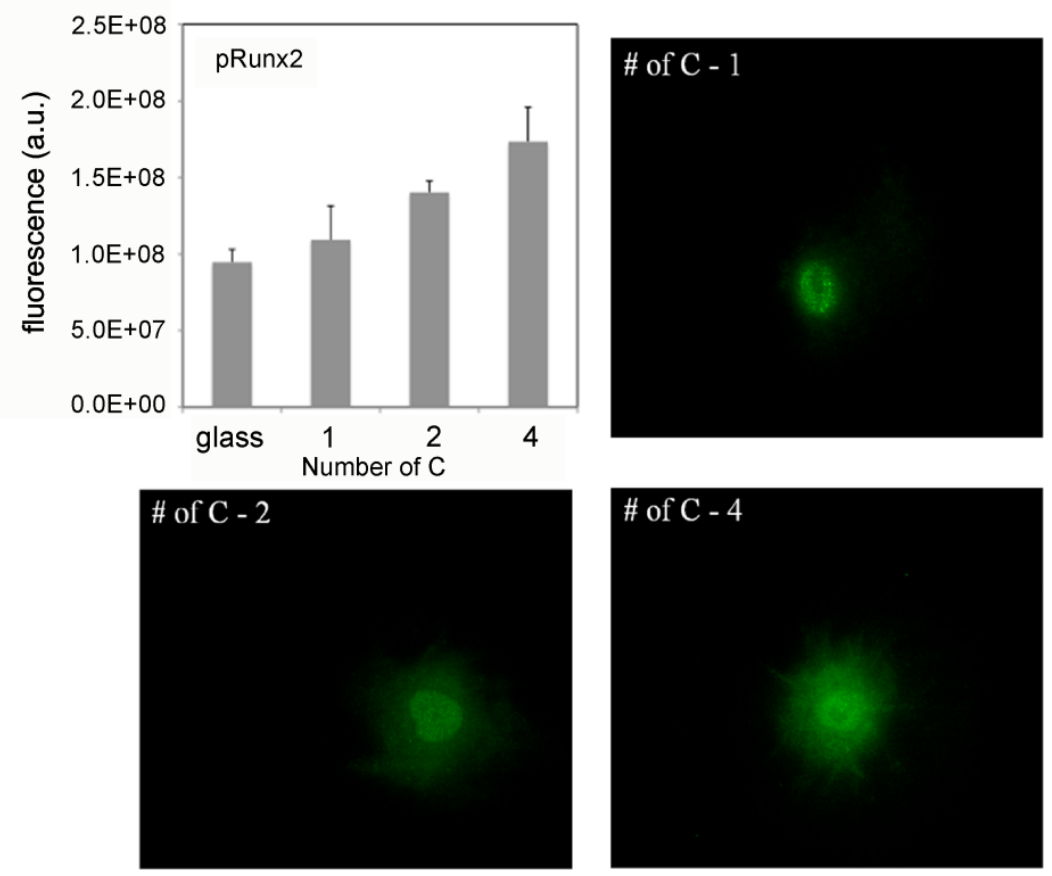

Figure 5.10 Phosphorylation of Runx2 staining of osteoprogenitors after 1 day of culture on the different surfaces containing increasing number of carbons in the side group, PMA (1), PEA (2) and PBA (4). The graph shows quantification from images as described previously in experimental section and Figure 5.7

These results present evidence of a non-monotonical dependence of mesenchymal stem cell differentiation on a family of substrates with subtle variations of surface chemistry, namely the sequential addition of methyl groups in the side group of a vinyl chain (Figure 5.1). The effect of matrix elasticity on mesenchymal stem cell differentiation has been described to occur on synthetic substrates of stiffness that mimic the physiological tissue microenvironment, that for osteoblastic lineages should be in the range of osteoid precursors of bone (25 - $40 \mathrm{kPa})$ [4]. Figure 5.1c shows that the elastic modulus measured for PEA and PBA is one order of magnitude higher (500 kPa) that the stiffness of the bone natural microenvironment. Thus, since cells must deform the substrate to sense the substrate, taking into account the range of forces cells 
can exert (which range from 1 to $5 \mathrm{nN} / \mu^{2}$ ) [47-48] as well as the distribution of focal adhesions that have been quantified (Figure 5.6), it would appear that cells are not able to deform the underlying substrates and, consequently, both PEA ( $x=2)$ and PBA $(x=4)$ must be sensed as simply rigid substrates by cells. This would indicate changes are not linked to stiffness [53].

There is some evidence that the mobility of the adhesion ligands at the cellmaterial interface improves cell behavior. Increasing the tether length of a synthetic peptide containing the RGD and the synergy sequence PHSRH to the underlying substrate, enhanced cell spreading and reduced the time to form focal adhesions [57]. Similarly, disorder can be interpreted as one form of mobility, and it was found that disordered nanopatterns of RGD on a bioinert background provided a much greater variety of ligand density for positive cell adhesion [58]. On a more physical ground, disorder and mobility are related to the same thermodynamic magnitude: entropy; which would suggest that surfaces of higher entropy would favor cell adhesion. Furthermore, osteoblast differentiation of skeletal stem cells has been found to be enhanced on disorder nanoscale topographies [6], that can be equally described as surfaces of increased entropy as compared to the order system with qualitatively the same nanotopography. In this study we demonstrate that even if $\mathrm{FN}$ is adsorbed with the same density and supramolecular distribution on PEA $(x=2)$ and PBA $(x=4)$, cell differentiation along the osteoblastic lineages is enhanced on PBA $(x=4)$ (Figures 5.8-5.10) on which more focal adhesions are found (Figure 5.6). The glass transition temperature of PBA $(x=4)$ is $30^{\circ} \mathrm{C}$ below that of PEA $(x=2)$, which means that surface mobility is enhanced on PBA.

This property can also be related to the fact that the organization of FN takes place with faster dynamics on PBA than PEA, i.e. a FN network was formed from lower concentrations of the adsorbing FN solution on PBA than on PEA. Strikingly, surface mobility not only enhanced cell adhesion, as previously shown for other systems [59], as seen by the higher number of focal adhesion plaques found in PBA $(x=4)$ than PEA $(x=2)$ (Figure 5.6), but it targets skeletal 
stem cell differentiation along the osteoblastic lineage with greater efficiency, as shown by the upregulation of characteristic osteoblastic markers osteocalcin, osteopontin and Runx2 (Figures 5.8-5.10). In addition, it has been recently shown that subtle differences in $-\mathrm{CH}_{3}$ chain lengths (an associated surface mobility) are able to induce changes in MSC phenotype [10], supporting a direct effect of surface mobility on cell differentiation.

\subsection{Conclusions}

The system based on a vinyl chain with the side groups $-\mathrm{COO}\left(\mathrm{CH}_{2}\right)_{x} \mathrm{H}$, where $x=1,2,4$, allows assessment of the influence of minute variations in surface chemistry in protein adsorption, cell adhesion and cell differentiation.

Even if the amount of adsorbed FN on each substrate remains constant, the distribution of the protein -its supramolecular assembly- on the substrate's surface is sensitive to minute changes in substrate chemistry. Thus, transition from $x=1$ to $x=2$ drastically alters $F N$ distribution at the cell-material interface, from a globular form on PMA to the formation of a well-interconnected FN network on PEA, such that other physical parameters of the matrix (e.g. stiffness) do not play any role in cell response. That is to say, one cannot compare the cellular behavior on PMA and the other two surfaces and ascribe their differences to the effect of the physical properties of the substrate, since there are qualitative differences in fibronectin activity among surfaces. However, $\mathrm{FN}$ activity (surface density and distribution) is similar on the surfaces $\mathrm{x}=2$ and $x=4$, which allows the investigation of the role of other physical properties of the matrix on cell differentiation.

Stiffness of this family of surfaces is well above the physiological elastic moduli of the osteoid precursors of bone, and consequently material surfaces behave simply as stiff surfaces for the cell mechanomachinery. Nevertheless, surface mobility is higher on $x=4$ than $x=2$, as quantified by the glass transition temperature of the system, which enhanced cell adhesion and enhanced 
differentiation of mesenchymal stem cells to the osteoblastic lineage. Thus, this study has identified surface mobility, and its quantification by the glass transition temperature, as a new physical parameter of the matrix able to direct skeletal stem cell differentiation. Our findings indicate the potential to modulate stem and progenitor cell commitment along desired lineages through surface mobility of the underlying material surface. 


\subsection{References}

1. M.F. Pittenger, A.M. Mackay, S.C. Beck, R.K. Jaiswal, R. Douglas, J.D. Mosca, M.A. Moorman, D.W. Simonetti, S. Craig, D.R. Marshak. Multilineage Potential of Adult Human Mesenchymal Stem Cells. Science, 1999. 284, 143-147.

2. M.F. Pittenger. Mesenchymal stem cells from adult bone marrow. Methods in molecular biology, 2008. 449, 27-44.

3. R. McBeath, D.M. Pirone, C.M. Nelson, K. Bhadriraju, C.S. Chen. Cell Shape, Cytoskeletal Tension, and RhoA Regulate Stem Cell Lineage Commitment. Developmental Cell, 2004. 6, 483-495.

4. A.J. Engler, S. Sen, H.L. Sweeney, D.E. Discher. Matrix Elasticity Directs Stem Cell Lineage Specification. Cell, 2006. 126, 677-689.

5. N. Huebsch, P.R. Arany, A.S. Mao, D. Shvartsman, O.A. Ali, S.A. Bencherif, J. Rivera-Feliciano, D.J. Mooney. Harnessing traction-mediated manipulation of the cell/matrix interface to control stem-cell fate. Nat Mater, 2010. 9, 518-526.

6. M.J. Dalby, N. Gadegaard, R. Tare, A. Andar, M.O. Riehle, P. Herzyk, C.D.W. Wilkinson, R.O.C. Oreffo. The control of human mesenchymal cell differentiation using nanoscale symmetry and disorder. Nature Materials, 2007. 6, 997-1003.

7. S. Oh, K.S. Brammer, Y.S.J. Li, D. Teng, A.J. Engler, S. Chien, S. Jin. Stem cell fate dictated solely by altered nanotube dimension. Proceedings of the National Academy of Sciences, 2009. 106, 2130-2135.

8. L.E. McNamara, R.J. McMurray, M.J.P. Biggs, F. Kantawong, R.O.C. Oreffo, M.J. Dalby. Nanotopographical control of stem cell differentiation. Journal of Tissue Engineering, 2010. 2010, 120623.

9. J.E. Phillips, T.A. Petrie, F.P. Creighton, A.J. García. Human mesenchymal stem cell differentiation on self-assembled monolayers presenting different surface chemistries. Acta Biomaterialia, 2010. 6, 12-20.

10. J.M. Curran, F. Pu, R. Chen, J.A. Hunt. The use of dynamic surface chemistries to control msc isolation and function. Biomaterials, 2011. 32, 4753-4760.

11. J.M. Curran, R. Chen, J.A. Hunt. The guidance of human mesenchymal stem cell differentiation in vitro by controlled modifications to the cell substrate. Biomaterials, 2006. 27, 4783-4793.

12. F. Grinnell. Focal adhesion sites and the removal of substratum-bound fibronectin. The Journal of Cell Biology, 1986. 103, 2697-2706. 
13. U.S. Schwarz, I.B. Bischofs. Physical determinants of cell organization in soft media. Medical Engineering \&amp; Physics, 2005. 27, 763-772.

14. J.D. Sipe. Tissue Engineering and Reparative Medicine. Annals of the New York Academy of Sciences, 2002. 961, 1-9.

15. C. Werner, T. Pompe, K. Salchert. Modulating Extracellular Matrix at Interfaces of Polymeric Materials. in Polymers for Regenerative Medicine, C. Werner, Editor. 2006, Springer Berlin / Heidelberg: 63-93.

16. K. Anselme, M. Bigerelle, B. Noel, E. Dufresne, D. Judas, A. lost, P. Hardouin. Qualitative and quantitative study of human osteoblast adhesion on materials with various surface roughnesses. Journal of Biomedical Materials Research, 2000. 49, 155-166.

17. D.E. Discher, P. Janmey, Y.-I. Wang. Tissue Cells Feel and Respond to the Stiffness of Their Substrate. Science, 2005. 310, 1139-1143.

18. R.J. Pelham, Y.-I. Wang. Cell locomotion and focal adhesions are regulated by substrate flexibility. Proceedings of the National Academy of Sciences, 1997. 94, 13661-13665.

19. L.A. Flanagan, Y.E. Ju, B. Marg, M. Osterfield, P.A. Janmey. Neurite branching on deformable substrates. Neuroreport, 2002. 13, 2411-2415.

20. A. Schneider, G. Francius, R. Obeid, P. Schwinté, J. Hemmerlé, B. Frisch, P. Schaaf, J.-C. Voegel, B. Senger, C. Picart. Polyelectrolyte Multilayers with a Tunable Young's Modulus: Influence of Film Stiffness on Cell Adhesion. Langmuir, 2005. 22, 1193-1200.

21. P.L. Ryan, R.A. Foty, J. Kohn, M.S. Steinberg. Tissue spreading on implantable substrates is a competitive outcome of cell-cell vs. cell-substratum adhesivity. Proceedings of the National Academy of Sciences, 2001. 98, 4323-4327.

22. J.Y. Wong, A. Velasco, P. Rajagopalan, Q. Pham. Directed Movement of Vascular Smooth Muscle Cells on Gradient-Compliant Hydrogelst. Langmuir, 2003. 19, 1908-1913.

23. C.-M. Lo, H.-B. Wang, M. Dembo, Y.-I. Wang. Cell movement is guided by the rigidigy of the substrate. Biophysical Journal, 2000. 79, 144-152.

24. K. Saha, A.J. Keung, E.F. Irwin, Y. Li, L. Little, D.V. Schaffer, K.E. Healy. Substrate Modulus Directs Neural Stem Cell Behavior. Biophysical Journal, 2008. 95, 44264438. 
25. A.S. Rowlands, P.A. George, J.J. Cooper-White. Directing osteogenic and myogenic differentiation of MSCs: interplay of stiffness and adhesive ligand presentation. American Journal of Physiology - Cell Physiology, 2008. 295, C1037C1044.

26. J.S. Park, J.S. Chu, A.D. Tsou, R. Diop, Z. Tang, A. Wang, S. Li. The effect of matrix stiffness on the differentiation of mesenchymal stem cells in response to TGF- $\beta$. Biomaterials, 2011. 32, 3921-3930.

27. Y.H. Bae, P.A. Johnson, C.A. Florek, J. Kohn, P.V. Moghe. Minute changes in composition of polymer substrates produce amplified differences in cell adhesion and motility via optimal ligand conditioning. Acta Biomaterialia, 2006. 2, 473-482.

28. P. Rico, J.C. Rodríguez Hernández, D. Moratal, G. Altankov, M. Monleón Pradas, M. Salmerón-Sánchez. Substrate-Induced Assembly of Fibronectin into Networks: Influence of Surface Chemistry and Effect on Osteoblast Adhesion. Tissue Engineering: Part A, 2009. 15, 3271-3281.

29. N. Otsu. A Threshold Selection Method from Gray-Level Histograms. IEEE Transactions on Systems, Man, and Cybernetics, 1979. 9, 62-66.

30. X.B. Yang, H.I. Roach, N.M.P. Clarke, S.M. Howdle, R. Quirk, K.M. Shakesheff, R.O.C. Oreffo. Human osteoprogenitor growth and differentiation on synthetic biodegradable structures after surface modification. Bone, 2001. 29, 523-531.

31. D. Howard, K. Partridge, X. Yang, N.M.P. Clarke, Y. Okubo, K. Bessho, S.M. Howdle, K.M. Shakesheff, R.O.C. Oreffo. Immunoselection and adenoviral genetic modulation of human osteoprogenitors: in vivo bone formation on PLA scaffold. Biochemical and biophysical research communications, 2002. 299, 208-215.

32. P.J. Simmons, B. Torok-Storb. Identification of stromal cell precursors in human bone marrow by a novel monoclonal antibody, STRO-1. Blood, 1991. 78, 55-62.

33. J.T. Triffitt, C.J. Joyner, R.O.C. Oreffo, A.S. Virdi. Osteogenesis: bone development from primitive progenitors. Biochemical Society Transactions, 1998. 26, 21-27.

34. X. Yang, R.S. Tare, K.A. Partridge, H.I. Roach, N.M.P. Clarke, S.M. Howdle, K.M. Shakesheff, R.O.C. Oreffo. Induction of Human Osteoprogenitor Chemotaxis, Proliferation, Differentiation, and Bone Formation by Osteoblast Stimulating Factor1/Pleiotrophin: Osteoconductive Biomimetic Scaffolds for Tissue Engineering. Journal of Bone and Mineral Research, 2003. 18, 47-57.

35. S.-H. Mirmalek-Sani, R.S. Tare, S.M. Morgan, H.I. Roach, D.I. Wilson, N.A. Hanley, R.O.C. Oreffo. Characterization and Multipotentiality of Human Fetal 
Femur?Derived Cells: Implications for Skeletal Tissue Regeneration. Stem cells, 2006. 24, 1042-1053.

36. R.C. González, R.E. Woods, S.L. Eddins. Digital Image Processing Using MATLAB. 2003, Prentice-Hall, Upper Saddler River, NJ.

37. R.C. González, R.E. Woods. Digital Imaging Processing. 2007, Prentice-Hall, Upper Saddle River, NJ.

38. T. Mathworks. MATLAB Image Processing Toolbox User's Guide. 2006, Natick, MA. The MathWorks, Inc.

39. G.E. Strobl. The physics of polymers: concepts for understanding their structures and behavior. 1997, Berlín. Springer.

40. Z. Yang, Y. Fujii, F.K. Lee, C.-H. Lam, O.K.C. Tsui. Glass Transition Dynamics and Surface Layer Mobility in Unentangled Polystyrene Films. Science, 2010. 328, 1676-1679.

41. G. Altankov, V. Thom, T. Groth, K. Jankova, G. Jonsson, M. Ulbricht. Modulating the biocompatibility of polymer surfaces with poly(ethylene glycol): Effect of fibronectin. Journal of Biomedical Materials Research, 2000. 52, 219-230.

42. A.J. García, D. Boettiger. Integrin-fibronectin interactions at the cell-material interface: initial integrin binding and signaling. Biomaterials, 1999. 20, 2427-2433.

43. D. Gugutkov, G. Altankov, J.C. Rodríguez Hernández, M. Monleón Pradas, M. Salmerón Sánchez. Fibronectin activity on substrates with controlled -OH density. Journal of Biomedical Materials Research Part A, 2010. 92A, 322-331.

44. D. Gugutkov, C. González-García, J.C. Rodríguez Hernández, G. Altankov, M. Salmerón-Sánchez. Biological Activity of the Substrate-Induced Fibronectin Network: Insight into the Third Dimension through Electrospun Fibers. - Langmuir, 2009. 25, 10893-10900.

45. M. Salmerón-Sánchez, P. Rico, D. Moratal, T.T. Lee, J.E. Schwarzbauer,A.J. García. Role of material-driven fibronectin fibrillogenesis in cell differentiation. Biomaterials, 2011. 32, 2099-2105.

46. A.S. Rowlands, P.A. George, J.J. Cooper-White. Directing osteogenic and myogenic differentiation of MSCs: interplay of stiffness and adhesive ligand presentation. Americam Journal of Physiology: Cell Physiology, 2008. 295, C10371044.

47. N.Q. Balaban, U.S. Schwarz, D. Riveline, P. Goichberg, G. Tzur, I. Sabanay, D. Mahalu, S. Safran, A. Bershadsky, L. Addadi, B. Geiger. Force and focal adhesion 
assembly: a close relationship studied using elastic micropatterned substrates. Nature Cell Biology, 2001. 3, 466-472.

48. C.G. Galbraith, K.M. Yamada, M.P. Sheetz. The relationship between force and focal complex development. The Journal of Cell Biology, 2002. 25, 695-705.

49. G. De Santis, A.B. Lennon, F. Boschetti, B. Verhegghe, P. Verdonck, P.J. Prendergast. How can cells sense the elasticity of a substrate? An analysis using a cell tensegrity model. European Cells and Materials, 2011. 22, 202-213.

50. T. Yeung, P.C. Georges, L.A. Flanagan, B. Marg, M. Ortiz, M. Funaki, N. Zahir, W. Ming, V. Weaver, P.A. Janmey. Effects of substrate stiffness on cell morphology, cytoskeletal structure, and adhesion. Cell Motility and the Cytoskeleton, 2005. 60, 24-34.

51. A. Buxboim, K. Rajagopal, A.E.X. Brown, D.E. Discher. How deeply cells feel: methods for thin gels. Journal of Physics: Condensed Matter, 2010. 22, 194116.

52. J.M. Maloney, E.B. Walton, C.M. Bruce, K.J. Van Vliet. Influence of finite thickness and stiffness on cellular adhesion-induced deformation of compliant substrata. Physical review. E, Statistical, nonlinear, and soft matter physics, 2008. 78, 041923.

53. G.C. Reilly, A.J. Engler. Intrinsic extracellular matrix properties regulate stem cell differentiation. Special Issue on Cell Mechanobiology, 2010. 43, 55-62.

54. L.E. McNamara, T. Sjöström, K.E.V. Burgess, J.J.W. Kim, E. Liu, S. Gordonov, P.V. Moghe, R.M.D. Meek, R.O.C. Oreffo, B. Su, M.J. Dalby. Skeletal stem cell physiology on functionally distinct titania nanotopographies. Biomaterials, 2011. 32, 7403-7410.

55. V. Vogel, M.P. Sheetz. Local force and geometry sensing regulate cell functions. Nature Reviews Molecular Cell Biology, 2006. 7, 265-275.

56. A. Nicolas, B. Geiger, S.A. Safran. Cell mechanosensitivity controls the anisotropy of focal adhesions. Proceedings of the National Academy of Sciences of the United States of America, 2004. 101, 12520-12525.

57. W. Kuhlman, I. Taniguchi, L.G. Griffith, A.M. Mayes. Interplay Between PEO Tether Length and Ligand Spacing Governs Cell Spreading on RGD-Modified PMMA-gPEO Comb Copolymers. - Biomacromolecules, 2007. 8, 3206-3213.

58. J. Huang, S.V. Grater, F. Corbellini, S. Rinck, E. Bock, R. Kemkemer, H. Kessler, J. Ding, J.P. Spatz. Impact of Order and Disorder in RGD Nanopatterns on Cell Adhesion. - Nano Letters, 2009. 9, 1111-1116. 
59. H.J. Kong, T.R. Polte, E. Alsberg, D.J. Mooney. FRET measurements of celltraction forces and nano-scale clustering of adhesion ligands varied by substrate stiffness. Proceedings of the National Academy of Sciences of the United States of America, 2005. 102, 4300-4305. 



\section{Role of vitronectin in fibronectin activity at the cell-material interface}

\section{Summary}

The effect of vitronectin (VN), an ECM adhesion protein, on FN adsorption and cell-mediated FN reorganization is evaluated in this chapter. Poly(ethyl acrylate), PEA, an acrylic polymer which induces spontaneous fibronectin organization into well-developed networks was employed as a material substrate. FN adsorption, cell adhesion and cellular $\mathrm{FN}$ reorganization in the presence or absence of $\mathrm{VN}$ were analyzed. FN surface density and its distribution on PEA surfaces were altered when FN was adsorbed competitively with VN. The presence of adsorbed VN on the surfaces enhanced the cellmediated FN reorganization and secretion, in comparison with the $\mathrm{FN}$ reorganization process that took place either with pure $\mathrm{FN}$ or the presence of serum proteins. 



\subsection{Introduction}

The extracellular matrix (ECM) is a dynamic and heterogeneous meshwork of fibrillar and non-fibrillar components that provide an active microenvironment for cell adhesion, differentiation, migration and proliferation. ECM regulates numerous cell functions by activating multiple signalling pathways at adhesion sites which will trigger cell fate. However, cells interacting with the ECM are not only receiving information from specific cues in the ECM [1], but, simultaneously, and as consequence, cells respond to these inputs by remodelling the surrounding matrix and/or secreting new one [2-4]. ECM components are secreted by cells as non-functional protein units, which are assembled into functional supramolecular structures in a highly regulated manner [5-7]. The regulation of the matrix reorganization is an important process, since the matrix assembly is crucial for cells to develop their functions, so defects in ECM assembly can cause different diseases [8].

Fibronectin is an abundant component of the ECM and its assembly is the initial step which orchestrates the assembly of other ECM proteins, since FN fibrils possess binding sites for multiple ECM components, and promotes cell adhesion, growth, migration and signalling. Moreover, FN fibrils provide support for cell adhesion receptors (most notably integrins) that trigger different signalling pathways [6-7]. Because of that numerous researches have been focused in mimic the physiological FN network in vitro; by cell-free routes able to induce FN fibrillogenesis [9-13], and varying the extracellular environment (physicochemical properties of the substrate, ECM proteins adsorption,...) which triggers different cues that regulate the cell-mediated FN reorganization [14-16].

The influence of material properties on cellular $\mathrm{FN}$ reorganization in the presence of serum proteins has been investigated in numerous studies [17-19]. However, the individual effect of each of these proteins on FN fibrillogenesis has not been investigated yet. Among the ECM proteins, VN is a multi- 
functional adhesive glycoprotein found in the circulation and in different tissues, with a molecular weight of $75 \mathrm{kDa}$, and is involved in several physiological and pathological processes, including haemostasis, angiogenesis, tumour cell invasion and pericellular proteolysis, which involve matrix remodelling. VN contains binding sites for collagens, heparin, complement components, plasminogen and plasminogen activator inhibitor [20-21]. It engages and activates members of the integrin family $\left(\alpha_{v} \beta_{1}, \alpha_{v} \beta_{3}, \alpha_{v} \beta_{5}, \alpha_{\| \mathrm{lb}} \beta_{3}\right)$ through the RGD motif present in the molecule and this interaction contributes to cell adhesion, migration and integrin-mediated signal transduction. Moreover, the role of VN on FN fibrillogenesis has also been previously suggested [16]. The binding between $V N$ and its main cell surface receptor $-\alpha_{\vee} \beta_{3}$ integrin- initiated the $\mathrm{FN}$ fibrillogenesis by triggering the traslocation of $\alpha_{5} \beta_{1}$ integrins. The movement of $\mathrm{FN}$ receptors from focal adhesion and along fibrillar adhesions (ECM contacts) initiated FN fibrillogenesis by transmitting cytoskeletongenerated forces to extracellular FN molecules (Figure 6.1). 


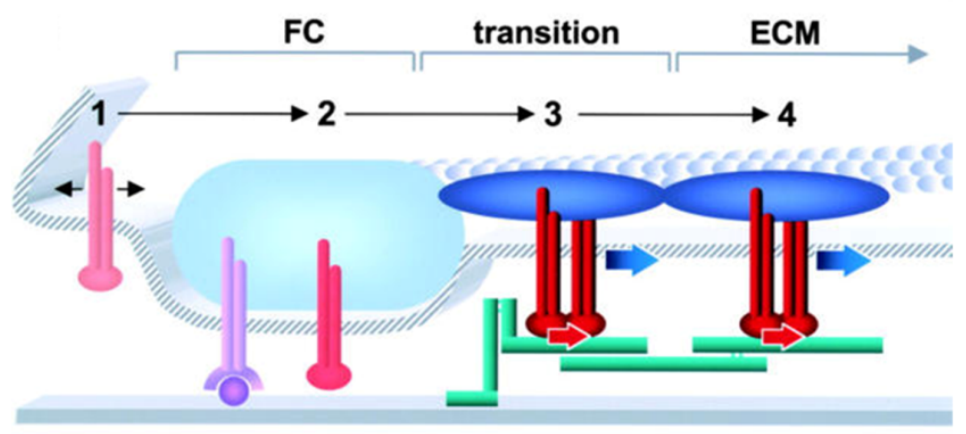

$\int \begin{aligned} & \alpha_{s} \beta_{1} \text { integrins } \\ & \text { (different activation states) }\end{aligned}$

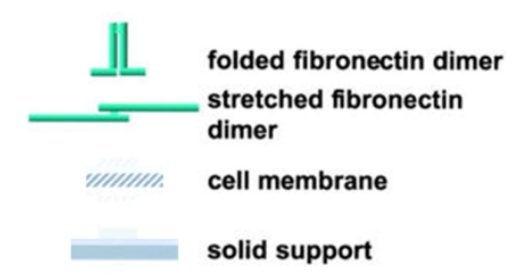

focal contact (FC) complex

ECM contact complexes

containing tensin

$\Rightarrow$ translocation force

F-actin

vitronectin receptor

vitronectin

pulling force

Figure 6.1 Model of early FN fibrillogenesis driven by $\alpha{ }_{5} \beta_{1}$ integrin translocation suggested by [16]. 1) Nonactivated integrins are diffusely distributed on the cell surface. 2) Within focal contacts (FC), $\alpha_{5} \beta_{1}$ integrins can be activated. 3) FN binding to $\alpha_{5} \beta_{1}$ integrins induces formation of homogeneous clusters of this integrin; the $\beta_{1}$ integrin cytoplasmic domains organize tensin-containing ECM complexes capable of translocating along actin filaments. 4) Moving ECM contact complexes pull $\alpha_{5} \beta_{1}$ integrins clusters out of FC into new fibrillar ECM contacts, which stretch bound FN molecules. Adapted from [16].

This work investigates $\mathrm{FN}$ and $\mathrm{VN}$ adsorption, under non-competitive and competitive conditions, on PEA surfaces; given that it is a material capable to trigger FN organization upon adsorption, leading to a physiological-like material-driven fibronectin fibrillogenesis in the absence of cells [14-15, 22]. Moreover, the presence of VN during FN adsorption allows a direct assessment of its effect on FN organization onto the surfaces and the subsequent cellmediated $\mathrm{FN}$ reorganization. 


\subsection{Materials and methods}

\subsubsection{Preparation of PEA films}

Polymer sheets were obtained by radical polymerization of a solution of the ethyl acrylate monomer (EA) (Sigma-Aldrich) using $0.35 \mathrm{wt} \%$ benzoin $(98 \%$ pure, Scharlau) as a photoinitiator. The polymerization was carried out up to limiting conversion for 12 hours. After polymerization, low molecular-mass substances were extracted from the material by drying in vacuo and $60^{\circ} \mathrm{C}$.

Thin films were prepared by making use of a spin-coater. To do that, the synthesized poly (ethyl acrylate) was dissolved in toluene (2.5 wt\%) (SigmaAldrich). Spin casting was performed on $12 \mathrm{~mm}$ glass coverslips at $2000 \mathrm{rpm}$ for $30 \mathrm{~s}$. Samples were dried in vacuo at $60^{\circ} \mathrm{C}$ before further characterization.

\subsubsection{Atomic force microscopy (AFM)}

AFM experiments were performed using a Multimode AFM equipped with NanoScope Illa controller (Digital Instruments-Veeco) operating in tapping mode in air. The Nanoscope 5.30r2 software version was used. Si-cantilevers (Veeco, Manchester, UK) were used with force constant of $2.8 \mathrm{~N} / \mathrm{m}$ and resonance frequency of $75 \mathrm{kHz}$. The phase signal was set to zero at a frequency of $5-10 \%$ lower than the resonance one, as suggested by manufacturer. Drive amplitude was $600 \mathrm{mV}$ and the amplitude setpoint $\left(A_{\mathrm{sp}}\right)$ was $2.2 \mathrm{~V}$. The ratio between the amplitude setpoint and the free amplitude $\mathrm{A}_{\mathrm{sp}} / \mathrm{A}_{0}$ was kept equal to 0.9 .

Samples were analyzed in the AFM to characterize the roughness of the substrate, and height, phase and amplitude magnitudes were recorded simultaneously for each image. In addition, in order to check the stability of the films, the surface of the materials was also scanned after immersion in PBS, and no significant modification in roughness was found. 


\subsubsection{Protein adsorption}

Protein adsorption was characterized by the adsorbed surface density (by Western Blot) and its distribution and conformation on the different substrates (by AFM).

\section{Protein distribution}

Fibronectin (Gibco) and vitronectin (Sigma-Aldrich) from human plasma were adsorbed on PEA substrates. For that, PEA films were immersed (for 10 $\min$ ) in several protein solutions of $10 \mu \mathrm{g} / \mathrm{ml}$ of total protein in PBS at different weight ratios of $\mathrm{FN} / \mathrm{VN}, 100 / 0,70 / 30,50 / 50,30 / 70$ and $0 / 100$. Both proteins were also individually adsorbed on PEA films from pure protein solutions of 3 , 5,7 and $10 \mu \mathrm{g} / \mathrm{ml}$ in PBS for $10 \mathrm{~min}$. After protein adsorption, samples were rinsed in PBS to eliminate the non-adsorbed protein. Remaining drops on the surface were dried by exposing the sample to a gentle nitrogen flow for 2-3 min.

Protein distribution onto the materials was evaluated by AFM in the tapping mode in air, immediately after sample preparation. Height, phase and amplitude magnitudes were recorded simultaneously for each image.

\section{Fibronectin quantification by Western Blot}

The amount of fibronectin adsorbed onto the substrates, from pure FN solutions and from FN-VN solutions, was quantified by Western Blot. For that, the remaining protein in the supernatant after adsorption onto the substrates for $1 \mathrm{~h}$ was measured as explained elsewhere [14]. Different aliquots of nonadsorbed protein on substrates were subjected to 5\%-SDS polyacrylamide gel electrophoresis (PAGE), using Laemmli buffer $2 x$ and denaturing standard conditions. Proteins were transferred to a positively charged polyvinylidene difluoride nylon membrane (GE Healthcare) using a semidry transfer cell system (Biorad), and blocked by immersion in 5\% skimmed milk in PBS for $1 \mathrm{~h}$ at room temperature. The blot was incubated with anti-human fibronectin polyclonal antibody (developed in rabbit, Sigma) (1:500) in PBS containing 
$0.1 \%$ TWEEN 20 and $2 \%$ skimmed milk for $1 \mathrm{~h}$ at room temperature and washed three times (10 min for each wash) with PBS containing $0.1 \%$ TWEEN 20. The blot was subsequently incubated in horseradish peroxidase-conjugated anti-rabbit immunoglobulin G (GE Healthcare) diluted 1:20000 in PBS containing TWEEN 20 and $2 \%$ milk ( $1 \mathrm{~h}$ at room temperature). The enhanced chemiluminescence detection system (GE Healthcare) was used according to the manufacturer's instructions prior to exposing the blot to X-ray film for $5 \mathrm{~min}$.

Analysis of the western blot bands was done using an in house software developed under MATLAB R2009a (The MathWorks, Inc., Natick, MA, USA). All the bands were digitized using the same scanner (Epson Stylus Photo RX500, Seiko Epson Corpo., Nagano, Japan) and the same scan parameters: 8 bits gray scale image and 300 dpi. The digitized images were binarized using the Otsu method, which chooses the threshold that minimizes the intraclass variance of the thresholded black and white pixels, in order to create a mask that automatically selected the edge of each western blot band [23]. This mask was applied to a negative version of the original scanned picture providing a resulting image which contained only the western bands. The last step of the process consisted of adding all the pixels that conformed each band correctly weighted by their intensity level.

\subsubsection{Cell culture}

Prior to seeding on substrates, NIH3T3 mouse embryonic fibroblast cells (European Collection of Cell Cultures) were maintained in DMEM medium supplemented with $1 \%$ penicillin-streptomycin and $10 \%$ calf serum, and passaged twice a week using standard techniques.

Sample disks (12 $\mathrm{mm}$ diameter) placed in a 24-well tissue culture plate were coated for $1 \mathrm{~h}$ with $\mathrm{FN}$ solutions of different concentrations $(3,5,7$ and 10 $\mu \mathrm{g} / \mathrm{ml}$ ) and $\mathrm{FN}-\mathrm{VN}$ solutions of $10 \mu \mathrm{g} / \mathrm{ml}$ in PBS at different ratios of both proteins $(100 / 0,70 / 30,50 / 50,30 / 70$ and $0 / 100)$. Then, $26 \cdot 10^{3}$ cells $\left(13 \cdot 10^{3}\right.$ 
cells $/ \mathrm{cm}^{2}$ ) were placed onto each substrate and were maintained at $37^{\circ} \mathrm{C}$ in a humidified atmosphere under $5 \% \mathrm{CO}_{2}$ for $3 \mathrm{~h}$.

\subsubsection{Cell adhesion}

After $3 \mathrm{~h}$ of incubation in serum-free conditions, cells were washed in Dulbecco's phosphate buffered saline (DPBS, Invitrogen) and fixed in formaldehyde solution $3.7 \%$ (Sigma) for $15 \mathrm{~min}$ at room temperature. Afterwards, the samples were rinsed with DPBS three times and a permeabilising buffer (10.3 g sucrose, $0.292 \mathrm{~g} \mathrm{NaCl}, 0.06 \mathrm{~g} \mathrm{MgCl}_{2}, 0.476 \mathrm{~g}$ Hepes buffer, $0.5 \mathrm{ml}$ Triton $\mathrm{X}$, in $100 \mathrm{ml}$ water, $\mathrm{pH}$ 7.2) was added at room temperature for $5 \mathrm{~min}$. In order to reduce the background signal, the samples were then incubated in $1 \%$ BSA/DPBS at room temperature for $30 \mathrm{~min}$. Then, samples were incubated in monoclonal mouse antibody against vinculin (1:400 in 1\% BSA/DPBS; Sigma) at room temperature for $1 \mathrm{~h}$. The samples were rinsed in $0.5 \%$ Tween 20/DPBS three times for 5 min each. Cy3-conjugated rabbit anti-mouse secondary antibody (1:200 in 1\% BSA/DPBS; Jackson Research) was then added at room temperature for $1 \mathrm{~h}$. Simultaneously, BODIPY FL phallacidin was added for the duration of this incubation 1 :40 in $1 \%$ BSA/PBS; Invitrogen). Finally, samples were washed in $0.5 \%$ Tween 20/DPBS three times before mounted in Vectashield containing DAPI (Vector Laboratories, Peterborough, UK). A Nikon fluorescent microscope was used for cellular imaging.

\subsubsection{Fibronectin reorganization}

The ability of cells to reorganise adsorbed FN (i.e. early matrix) was evaluated under different culture conditions. On the one hand, FN reorganization was monitoring after coating PEA films with several pure FN solution of different concentrations $(3,5$ and $7 \mu \mathrm{g} / \mathrm{ml})$ and seeding cells in calf serum containing medium. On the other hand, PEA films were coated with solutions of $\mathrm{FN}-\mathrm{VN}$ of $10 \mu \mathrm{g} / \mathrm{ml}$ at different ratios 100/0,70/30,50/50, 30/70 and 
0/100 and rinsed with PBS twice before seeding cells in serum-free conditions. After 3 hours, cells were washed in Dulbecco's phosphate buffered saline (DPBS, Invitrogen) and fixed in 3.7\% formaldehyde solution (Sigma) at room temperature for $15 \mathrm{~min}$. Samples were rinsed with DPBS and the permeabilization buffer was added at room temperature for $5 \mathrm{~min}$. $1 \%$ BSA/DPBS was added at room temperature for $30 \mathrm{~min}$. Samples were incubated with a polyclonal rabbit anti-FN antibody (1:400, Sigma), dissolved in $1 \%$ BSA/DPBS for $1 \mathrm{~h}$, washed, and incubated with a goat anti-rabbit Cy3conjugated secondary antibody for $1 \mathrm{~h}$ before washed and mounted with Vectashield containing DAPI. FN reorganization was monitoring by making use of a Nikon fluorescent microscope.

The cell-mediated FN reorganization was also assessed after incubation with antibody against $\beta_{1}$ integrin. PEA sample disks were coated with $10 \mu \mathrm{g} / \mathrm{ml}$ FN-VN solutions at $100 / 0$ and $30 / 70$ ratios, and rinsed with PBS twice before seeding $26 \cdot 10^{3}$ cells in each sample in serum-free conditions. After $1 \mathrm{~h}$ of culture, cells were incubated with a rat anti- $\beta_{1}$ integrin antibody (monoclonal anti-mouse CD29, BD Bioscience) for $1 \mathrm{~h}$ at $37^{\circ} \mathrm{C}$ to allow the antibody binding to dorsal $\beta_{1}$ integrins, thus the culture time was $2 \mathrm{~h}$. Then, cells were washed in Dulbecco's phosphate buffered saline (DPBS, Invitrogen) and fixed in $3.7 \%$ formaldehyde solution (Sigma) for $15 \mathrm{~min}$ at room temperature. Samples were rinsed with DPBS and saturated in 1\% BSA/DPBS at room temperature for 30 min. Afterwards, samples were incubated with a polyclonal rabbit anti-FN antibody (1:400, Sigma) dissolved in 1\% BSA/DPBS for $1 \mathrm{~h}$, washed, and incubated with a goat anti-rabbit Alexa 488-conjugated secondary antibody (1:200, Invitrogen) and a goat polyclonal anti-rat Cy3-conjugated secondary antibody (1:200, abcam) for $1 \mathrm{~h}$ before washing and mounting with Vectashield containing DAPI.

As a control, cells were also incubated on PEA samples for $2 \mathrm{~h}$ without exposing live cells to $\beta_{1}$ integrin antibody, and $F N$ and $\beta_{1}$ integrins were 
detected by immunofluorescence. Glass coverslides were employed as a control.

\subsection{Results and discussion}

Extracellular matrix of tissues in vivo is composed by different biological molecules that regulate the cell response by generating input signals for cells. The cell-mediated matrix assembly is a crucial process for cells to develop their functions. In this work, the influence of VN, an ECM adhesion glycoprotein, on $\mathrm{FN}$ adsorption and distribution at the material interface, as well as cell-mediated FN fibrillogenesis is investigated.

\subsubsection{Protein adsorption on PEA surfaces}

In order to evaluate the effect of vitronectin on fibronectin adsorption on PEA surfaces, the amount of adsorbed $\mathrm{FN}$ in the presence or absence of $\mathrm{VN}$ was determined by Western Blot. AFM was employed to analyze the distribution of both proteins onto the substrates.

\section{FN surface density}

The amount of FN adsorbed on PEA surfaces was quantified by image analysis of the western blot bands. Two known amounts of FN were charged in the gel to obtain the relationship between the protein concentration and the band intensity, which was employed to quantify the amount of FN adsorbed on the substrates. Figure 6.2 shows the quantification of the adsorbed FN on PEA surfaces from FN solutions of different concentrations $(10,7,5$ and $3 \mu \mathrm{g} / \mathrm{ml}$ ) in absence of VN (Figure 6.2; grey), and from solutions of both proteins, FN-VN $(10 \mu \mathrm{g} / \mathrm{ml})$, at different ratios $(100 / 0,70 / 30,50 / 50,30 / 70$ and 0/100) (Figure 6.2; black). In both cases, the amount of adsorbed FN decreases as the FN concentration in solution does. Surprisingly, a higher FN surface density was found on PEA surfaces when FN was adsorbed competitively with VN for the 
higher concentrations $(70 \%, 50 \%)$ : the amount of adsorbed $\mathrm{FN}$ in the presence of $\mathrm{VN}$ was higher than the adsorbed from pure $\mathrm{FN}$ solutions of equivalent concentration. However, when FN was adsorbed from a solution of $3 \mu \mathrm{g} / \mathrm{ml}$, the $\mathrm{FN}$ adsorption was not enhanced by the presence of $\mathrm{VN}$.

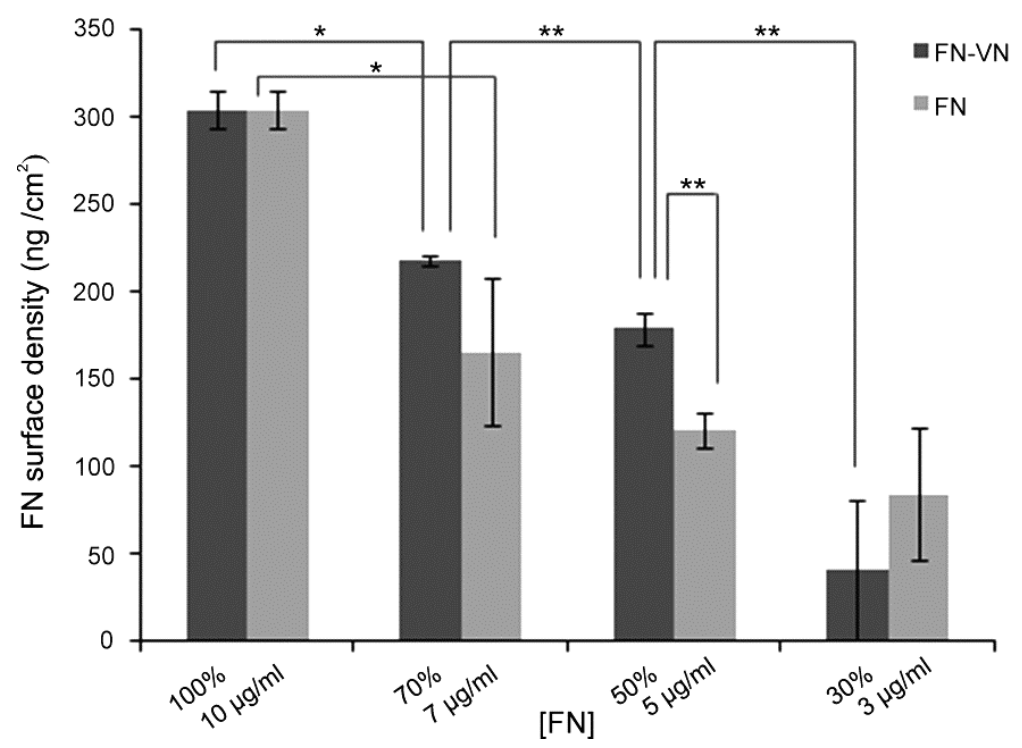

Figure 6.2 Fibronectin surface density on PEA films, from pure FN solutions of different concentration (grey) and for FN and VN competitively adsorbed from FN-VN solutions $(10 \mu \mathrm{g} / \mathrm{ml})$ at different ratios (black). Statistically significant differences (as determined by ANOVA) are indicated with ${ }^{*} P<0.05$ and ${ }^{* *} P<0.1$.

Although the individual adsorption of both proteins on PEA substrates has been previously studied [14, 24], the competitive adsorption of both proteins on this material had not been addressed yet. In previous studies, FN and VN were competitively adsorbed on substrates of different chemistry and surface wettability (including materials with similar wettability to PEA), showing that the amount of $\mathrm{FN}$ adsorbed on the different materials was lower as the $\mathrm{VN}$ concentration in solution increased; therefore, the presence of VN inhibited FN adsorption [25]. However, the results obtained in this work suggest that the VN enhances FN adsorption on PEA. This higher FN density obtained during the 
competitive adsorption process might be related to the conformation adopted by VN molecules adsorbed on this particular chemistry [24]. However, since no binding domain between $\mathrm{FN}$ and $\mathrm{VN}$ has been described [20, 26-27], the exposition of specific functional groups of adsorbed $\mathrm{VN}$ molecules seem not be responsible of the higher affinity. On the other hand, when the concentration of VN in solution is high enough $(70 \%)$, it seems that the $\mathrm{FN}$ molecules compete with $\mathrm{VN}$ molecules during adsorption, since lower FN surface density was found after competitive adsorption with $\mathrm{VN}$.

Protein adsorption on material surfaces is a process driven by both the intensity of the energetic interactions between the molecular groups and the entropic changes as a consequence of the unfolding of the protein as bound water is released from the surface [28-29]. When several proteins are dissolved together in a solution, the adsorption of each protein onto the substrate is influenced by the affinity between the protein and the substrate giving rise to a competitive process. In protein mixtures the adsorption behavior is often a result of an overlap of transport, adsorption, and repulsion processes. Small proteins diffuse faster than large ones and are the dominating species in the early adsorption stage. Therefore, in a binary solution of $\mathrm{FN}-\mathrm{VN}, \mathrm{VN}$ is probably the first one to be adsorbed, since $\mathrm{VN}$ is a lower molecular weight protein than $\mathrm{FN}[20,26]$. Once the $\mathrm{VN}$ is adsorbed, it might act as nucleation point for $\mathrm{FN}$ adsorption, since a protein diffusing in close proximity to the surface is more likely to adsorb if there are already pre-adsorbed proteins (cooperative effect) [30-31], increasing the adsorption rate as a result of increasing surface coverages $[30,32]$.

Although the amount of $\mathrm{VN}$ adsorbed on this material should be quantified to fully understand the competitive adsorption of these proteins on this material, the characterization of $\mathrm{FN}$ adsorption in the presence and absence of $\mathrm{VN}$ is enough to investigate the influence of $\mathrm{VN}$ on $\mathrm{FN}$ adsorption and cell response. 


\section{FN conformation and distribution}

The conformation and distribution of $F N$ and $V N$ on PEA surfaces was assessed by AFM. Figure 6.3 shows AFM phase images for FN and VN individually adsorbed from pure protein solutions of different concentrations 3 , 5,7 and $10 \mu \mathrm{g} / \mathrm{ml}$, for $10 \mathrm{~min}$. An interconnected FN network is observed when $\mathrm{FN}$ is adsorbed from a solution of concentration $10 \mu \mathrm{g} / \mathrm{ml}$ and the interconnectivity diminishes as the concentration of FN in solution does (Figure 6.3; a,f-h) as previously observed [14]. Whereas VN adopts a globular form when is adsorbed from the lowest concentration, and protein molecules associate into small aggregates after adsorption from solutions of higher concentrations (Figure 6.3; i-k,e) [24]. When VN is adsorbed form the highest concentration $(10 \mu \mathrm{g} / \mathrm{ml})$ the size of aggregates increases considerably (Figure $6.3 e)$.

Both proteins were also competitively adsorbed from solutions of $10 \mu \mathrm{g} / \mathrm{ml}$ of total protein concentration at different ratios of FN-VN, 100/0, 70/30, 50/50, $30 / 70$ and $0 / 100$ (first row), for $10 \mathrm{~min}$. The interconnectivity of the FN network, formed when $\mathrm{FN}$ is adsorbed from a pure solution of $10 \mu \mathrm{g} / \mathrm{ml}$, decreases as the ratio FN/VN in solution does. As observed in Figure 6.3, the adsorption of fibronectin, when $V N$ is present in the solution, gives rise to a more interconnected protein network compared to that obtained when $\mathrm{FN}$ is adsorbed at the same concentration from pure FN solutions (Figure 6.3, compare a-d and $f-h)$. 


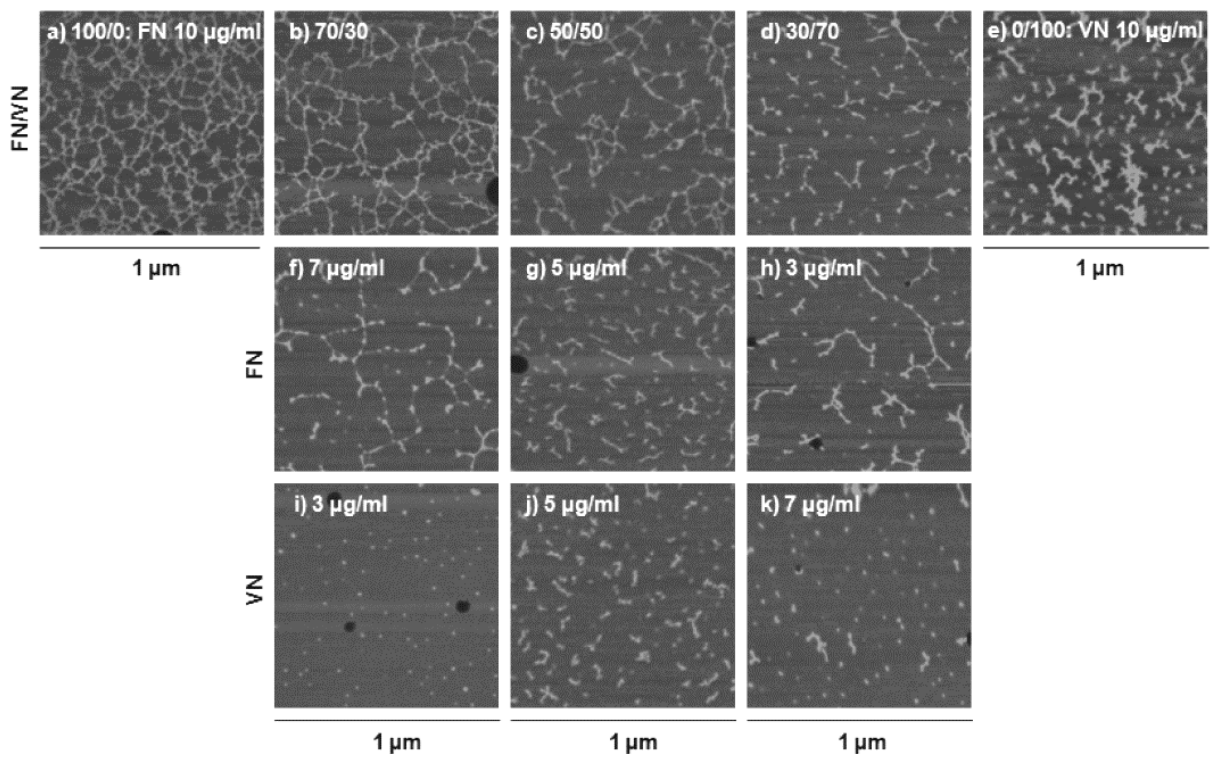

Figure 6.3 Conformation and distribution of FN and VN on PEA surfaces as observed by the phase magnitude in AFM. FN adsorbed from protein solutions of $10,7,5$ and $3 \mu \mathrm{g} / \mathrm{ml}$ (a,f-h). VN adsorbed from protein solutions of 3, 5, 7 and $10 \mu \mathrm{g} / \mathrm{ml}(\mathrm{i}-\mathrm{k}, \mathrm{e})$. FN and VN competitively adsorbed from protein solutions of $10 \mu \mathrm{g} / \mathrm{ml}$ at different ratios of FN/VN, 100/0, 70/30, 50/50, 30/70 and 0/100 (a-e).

AFM images do not allow distinguishing between molecules of both proteins. However, since VN induced FN adsorption (Figure 6.2), the more interconnected protein network observed in the presence of VN (Figure 6.3; bd) might be related to a higher amount of adsorbed FN [15]. Moreover, given that VN does not contain any specific binding domains for $F N$ and other VN molecules [20], VN is likely not to be biophysically linked to the FN network. Nevertheless, as $\mathrm{VN}$ is a lower molecular weight protein than $\mathrm{FN}$, when both proteins are adsorbed at the same time, VN could be trapped inside the $\mathrm{FN}$ network, and provide higher mobility to the FN network [33-37]. In addition, this higher mobility of the FN molecules adsorbed on the surfaces might contribute to a faster dynamics in forming the FN network, as occurs in the family of acrylic polymer investigated in chapter 4 . 


\subsubsection{Cell adhesion}

Figure 6.4 shows the overall morphology of cells adhering for $3 \mathrm{~h}$ on FN-VNcoated and FN-coated PEA surfaces, visualized via staining for actin (first and fourth column respectively). Cells presented prominent actic fibers inserting into well-developed focal adhesion complexes, as depicted in the central rows for vinculin (second row for FN-VN-coated PEA surfaces and third row for FNcoated PEA surfaces). Focal adhesions formation is lower as the concentration of $\mathrm{FN}$ in solution decreases (Figure $6.4 ; \mathrm{k}-\mathrm{m}$ ). Although cells adhered on PEA surfaces coated with both $\mathrm{FN}$ and $\mathrm{VN}$, as previously investigated [14, 24], for the same protein coating concentration, cells growing on FN-coated PEA surfaces (Figure $6.4 ; \mathrm{f}$ ) show larger focal adhesion plaques than those growing on VN-coated PEA surfaces (Figure 6.4; j). However, focal adhesions formation was similar on surfaces coated with protein solutions $(10 \mu \mathrm{g} / \mathrm{ml})$ of intermediate compositions of FN-VN (Figure $6.4 ; \mathrm{g}-\mathrm{i}$ ), and was higher than on surfaces where the $\mathrm{FN}$ was adsorbed from pure $\mathrm{FN}$ solutions of equivalent concentration (Figure 6.4; k-m). 


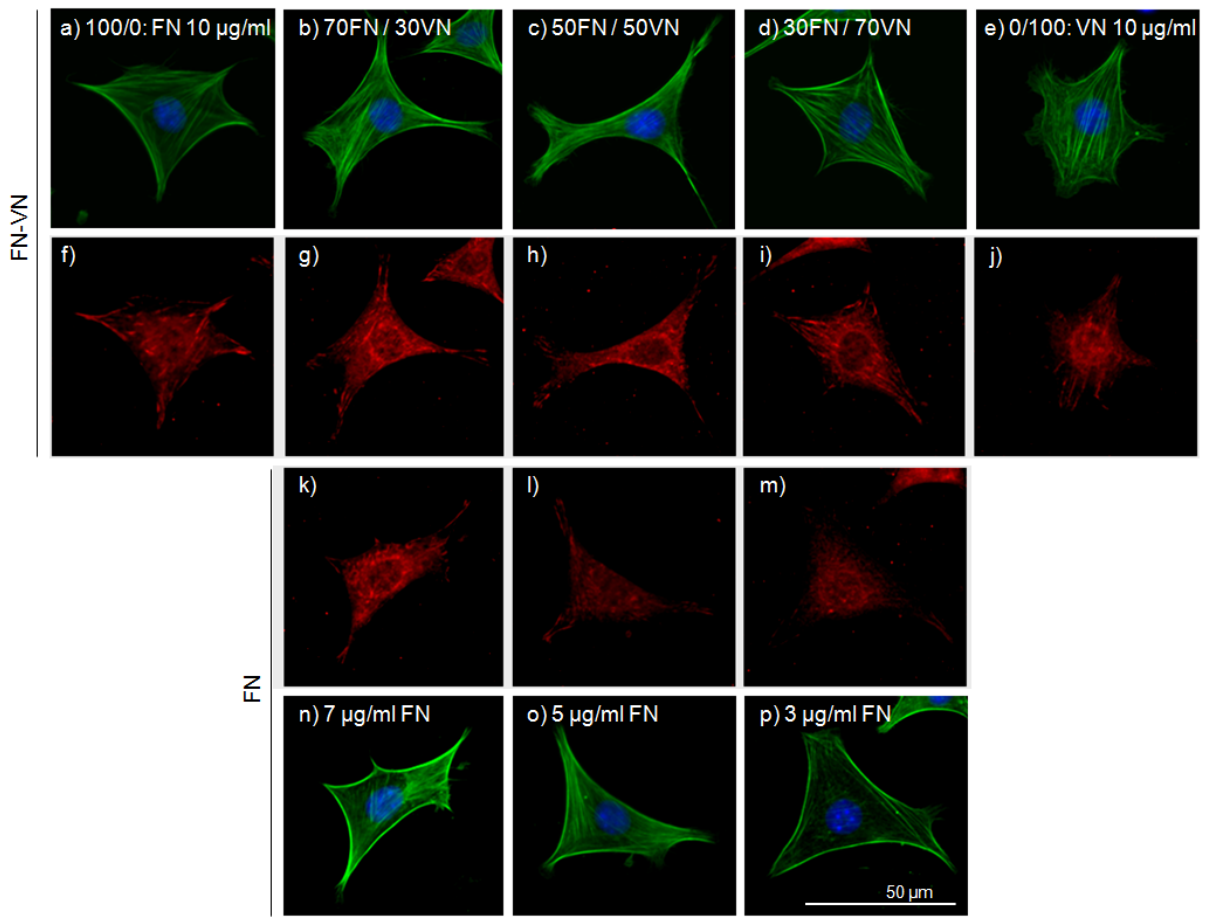

Figure 6.4 NIH3T3 fibroblasts after $3 \mathrm{~h}$ on FN-VN-coated (a-j) and FN-coated (k-p) PEA surfaces. First and fourth rows show F-actin cytoskeleton with nucleus counterstained with DAPI. The second and third rows show the focal adhesion plaques (vinculin).

According to these results, cell adhesion was enhanced on surfaces where the FN density was higher and the FN network was more interconnected. These results agree with the fact that the cell response is enhanced on surfaces where FN adopts a more biologically active, physiological-like distribution, i.e. the formation of a network of FN fibrils [15, 22]. Cells recognize faster and with higher affinity already assembled FN fibrils versus adsorbed protein. NIH3T3 cells showed higher focal adhesions formation on FN-coated surfaces, where FN was organized in a protein network, than on VN-coated surfaces, where VN adopted a globular form. Comparing PEA surfaces with the same FN concentration, cell adhesion was improved in the presence of VN, where a higher FN density and a more interconnected protein network were found. 


\subsubsection{Cellular FN reorganization}

Figure 6.5 shows the cellular reorganization of $\mathrm{FN}$ after $3 \mathrm{~h}$ of culture on $\mathrm{FN}$ VN-coated (first row) and FN-coated PEA surfaces (second row). It is observed that cells are able to reorganize $\mathrm{FN}$ in fibrils more actively as the FN surface density diminishes (Figure 6.5; a-d and e-g). Since previous investigations have shown that for cells to remove and reorganize the adsorbed FN layer in matrix fibrils, the material needs to adsorb proteins loosely [1, 38-40], the lower FN density adsorbed and the formation of a less interconnected network (Figures 6.2-6.3) probably facilitate the protein reorganization, due to the higher surface mobility [41]. However, cell-mediated FN reorganization is stronger on FN-VNcoated PEA surfaces compared to on FN-coated PEA surfaces (Figure 6.5; compare b-d and e-g): for a specific FN coating concentration, cells assemble FN much more actively in the presence of $\mathrm{VN}$; despite the $\mathrm{FN}$ surface density was higher. This fact supports the idea that $\mathrm{VN}$ is also adsorbed on surfaces and its presence has a stronger effect in $\mathrm{FN}$ fibrillogenesis compared to $\mathrm{FN}$ reorganization in the presence of proteins from calf serum in the culture medium. The presence of VN molecules could also contribute to increase the mobility of the FN network, as explained in section 6.3.1, which facilitates FN reorganization. Furthermore, VN molecules adsorbed on PEA surfaces can be recognized by cells and its binding to cell surface receptors might initiate $\mathrm{FN}$ assembly, as previously suggested [16]. Therefore, the VN adsorbed on this material enhanced the $\mathrm{FN}$ adsorption and $\mathrm{FN}$ reorganization. 

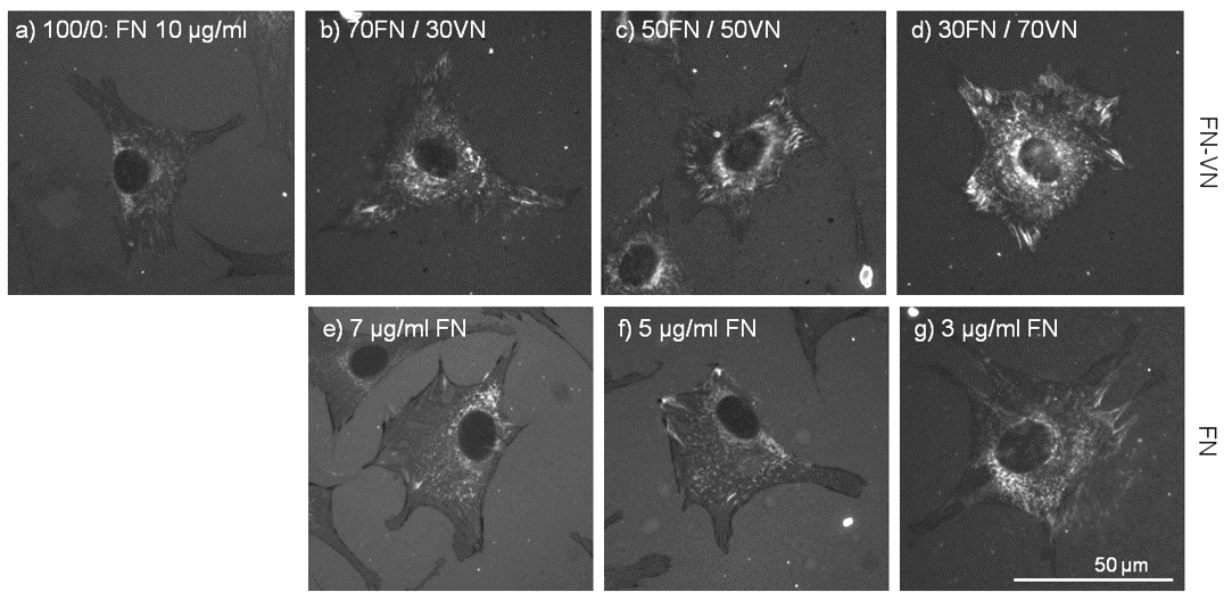

Figure 6.5 Cell-mediated FN reorganization after 3 hours incubation on FN-VN-coated PEA surfaces, in serum-free conditions (a-d) and on FN-coated PEA surfaces in serum containing conditions $(\mathrm{e}-\mathrm{g})$.

The assembly of fibronectin into a fibrillar matrix is a regulated step-wise process that involves binding to integrin receptors and interactions between fibronectin molecules. In most situations in vivo, matrix assembly occurs within existing three-dimensional (3D) extracellular matrix networks. Therefore, cell surface receptors (integrins) of the entire cell surface (ventral and dorsal) are activated and, after binding with extracellular matrix proteins, can trigger different signaling pathways which might not be equally activated in a twodimensional environment [42-45]. Seeking to mimic the reorganization that takes place in vivo, the cellular FN reorganization was also studied after activation of dorsal $\beta_{1}$ integrins by the binding of a monoclonal antibody. The activation of dorsal integrins might stimulate the reorganization of the adsorbed FN layer, by triggering signaling pathways and enhancing the affinity of FN binding $[42,46-47]$. Fibrils of assembled $F N$ might bind to the dorsal $\beta_{1}$ integrins closest to the cell-material interface, which could be the beginning of the formation of a three-dimensional extracellular matrix along the dorsal cell surface. 
After $1 \mathrm{~h}$ of cell adhesion in serum free conditions, NiH3T3 cells were incubated for $1 \mathrm{~h}$ with a primary antibody against $\beta_{1}$ integrins to allow the dorsal activation of these integrins. Afterwards, extracellular FN and dorsal $\beta_{1}$ integrin were detected with antibodies without permeabilizing cells, in order to visualize only the reorganized FN on the dorsal cell surface. That is to say, the ability of cells to remove adsorbed $\mathrm{FN}$ at the material interface and start assembling a 3D matrix. Figure 6.6 shows the cellular reorganization of $F N$ after dorsal $\beta_{1}$ integrins excitation. First column shows $\mathrm{FN}$ reorganization on $\mathrm{FN}$-coated glass and PEA substrates in the presence or absence of VN. When FN is adsorbed without any other ECM protein and cells are seeded in serum-free conditions, the production of $\mathrm{FN}$ and its organization on fibrils on the dorsal cell surface is almost absent in both glass and PEA substrates. However, when FN is coadsorbed with $30 \%$ of $\mathrm{VN}$, reorganization takes place much more actively on glass than on PEA surface, where is almost absent. This supports the idea that the presence of $\mathrm{VN}$ enhances $\mathrm{FN}$ reorganization, by providing higher mobility to the FN network, as well as specific sites for binding cell surface receptors, which might initiate FN assembly [16]. Moreover, a higher reorganization of the adsorbed FN occurs on hydrophilic glass, which is a substrate that bounds proteins loosely and leads to strong cell rearrangement of the adsorbed protein layer [48] (comparing to PEA substrate).

Dorsal $\beta_{1}$ expression is higher for cells on FN-VN-coated glass and PEA surfaces than cells on FN-coated substrates, as observed in the second column of Figure 6.6. Moreover, FN fibrils are observed co-localizing with dorsal $\beta_{1}$ integrins on glass substrate (third column), where FN reorganization is higher, which suggest the binding between the $\mathrm{FN}$ fibrils and these activated dorsal integrins. 


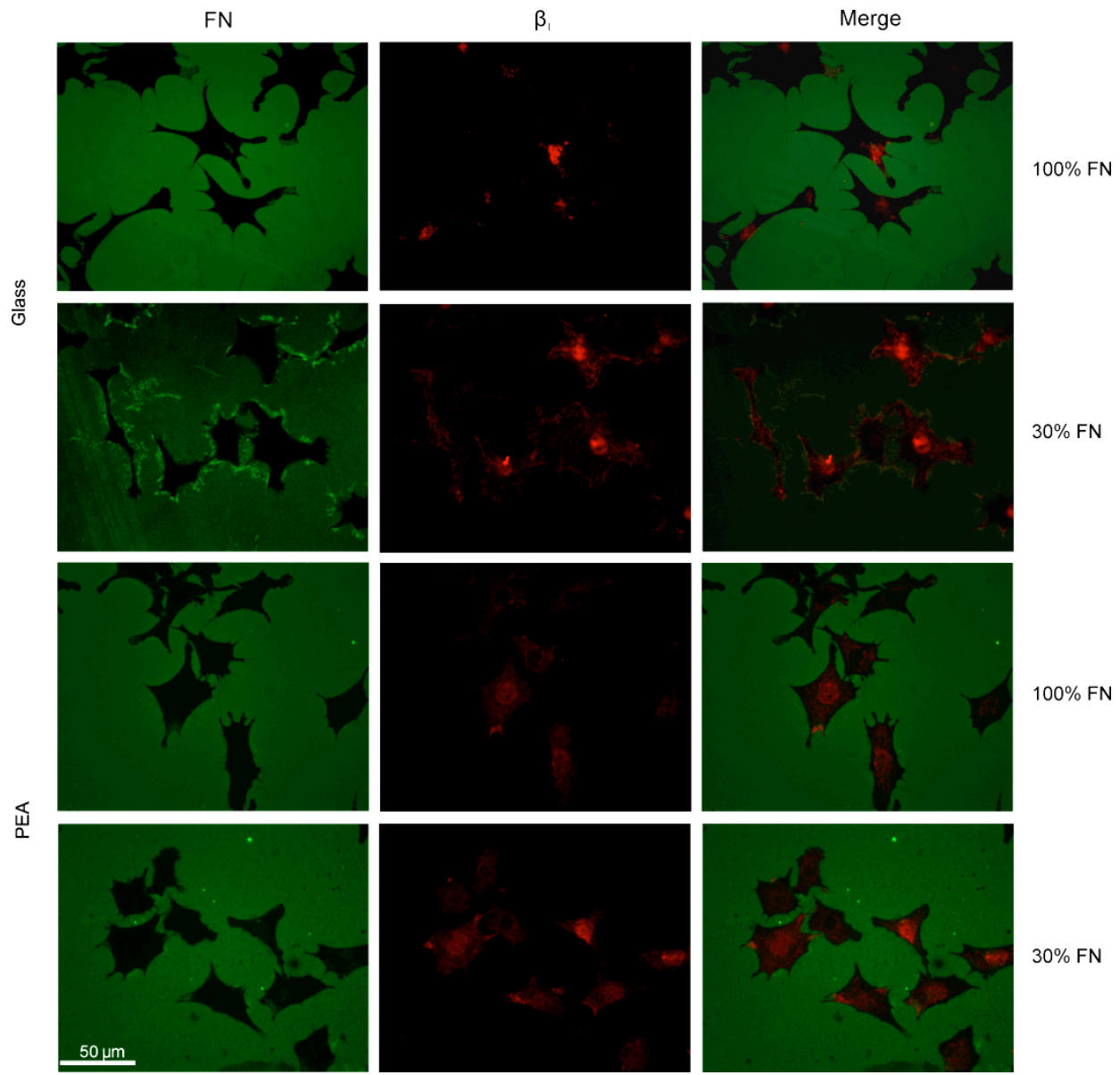

Figure 6.6 Cell-mediated FN reorganization after dorsal $\beta_{1}$ integrins excitation on FN and FN-VN-coated substrates (labelled FN on first column). $\beta_{1}$ integrin is shown in the second column. The third column is the superposition of the other two.

In the case of PEA, by comparing the FN reorganization observed without activation of dorsal integrins (Figure 6.5) and after dorsal $\beta_{1}$ integrin excitation (Figure 6.6), it seems that the most of the reorganized FN on Figure 6.5 takes place in the ventral cell surface, and much higher reorganization would be required to allow the binding of $F N$ fibrils to the activated dorsal $\beta_{1}$ integrins. 


\subsection{Conclusions}

This work investigates the role of vitronectin in fibronectin adsorption on PEA surfaces, and the subsequent cell adhesion and cellular FN reorganization. To do so, $\mathrm{FN}$ and $\mathrm{VN}$ adsorption, under non-competitive and competitive conditions, was investigated on PEA surfaces. On this material substrate, where $\mathrm{FN}$ is organized into well developed networks, the presence of $\mathrm{VN}$ enhances $\mathrm{FN}$ adsorption. Higher amount of FN adsorbed on PEA surfaces was found when FN and VN were competitively adsorbed, and a more interconnected FN network was formed as compared to solutions containing the same amount of $\mathrm{FN}$ and no VN. Moreover, the presence of VN during FN adsorption is likely to provide higher mobility to the FN network, contributing to enhance cell adhesion and cell-mediated $\mathrm{FN}$ reorganization.

In addition, the ability of cells to remove adsorbed $\mathrm{FN}$ at the material interface and start assembling a 3D matrix was evaluated on PEA and glass surfaces. Hydrophilic glass, a surface that bounds proteins loosely, leads to a strong $\mathrm{FN}$ reorganization in the presence of $\mathrm{VN}$, allowing the binding of $\mathrm{FN}$ fibrils to activated dorsal $\beta_{1}$ integrins. However, on PEA surfaces, where FNsubstrate interaction is stronger, cell-mediated $\mathrm{FN}$ reorganization was lower, making it difficult the binding of $\mathrm{FN}$ fibrils, assembled in the ventral cell surface, to the dorsal $\beta_{1}$ integrins. 


\subsection{References}

1. G. Altankov, T. Groth. Reorganization of substratum-bound fibronectin on hydrophilic and hydrophobic materials is related to biocompatibility. Journal of Materials Science: Materials in Medicine, 1994. 5, 732-737.

2. Z. Avnur, B. Geiger. The removal of extracellular fibronectin from areas of cellsubstrate contact. Cell, 1981. 25, 121-132.

3. R.O. Hynes. Integrins: Bidirectional, Allosteric Signaling Machines. Cell, 2002. 110, 673-687.

4. F. Grinnell. Focal adhesion sites and the removal of substratum-bound fibronectin. The Journal of Cell Biology, 1986. 103, 2697-2706.

5. X. Zhou, R.G. Rowe, N. Hiraoka, J.P. George, D. Wirtz, D.F. Mosher, I. Virtanen, M.A. Chernousov, S.J. Weiss. Fibronectin fibrillogenesis regulates threedimensional neovessel formation. Genes \& development, 2008. 22, 1231-1243.

6. I. Vakonakis, I.D. Campbell. Extracellular matrix: from atomic resolution to ultrastructure. Current Opinion in Cell Biology, 2007. 19, 578-583.

7. M. Larsen, V.V. Artym, J.A. Green, K.M. Yamada. The matrix reorganized: extracellular matrix remodeling and integrin signaling. Current Opinion in Cell Biology, 2006. 18, 463-471.

8. P. Singh, C. Carraher, J.E. Schwarzbauer. Assembly of Fibronectin Extracellular Matrix. Annual Review of Cell and Developmental Biology, 2010. 26, 397-419.

9. K. Sakai, T. Fujii, T. Hayashi. Cell-Free Formation of Disulfide-Bonded Multimer from Isolated Plasma Fibronectin in the Presence of a Low Concentration of SH Reagent under a Physiological Condition. Journal of Biochemistry, 1994. 115, 415421.

10. D.F. Mosher, R.B. Johnson. In vitro formation of disulfide-bonded fibronectin multimers. Journal of Biological Chemistry, 1983. 258, 6595-6601.

11. D.C. Hocking, R.K. Smith, P.J. McKeown-Longo. A novel role for the integrinbinding III-10 module in fibronectin matrix assembly. The Journal of Cell Biology, 1996. 133, 431-444.

12. J. Ulmer, B. Geiger, J.P. Spatz. Force-induced fibronectin fibrillogenesis in vitro. Soft Matter, 2008. 4, 1998-2007.

13. S. Underwood, A. Afoke, R.A. Brown, A.J. MacLeod, P. a Shamlou, P. Dunnill. Wet extrusion of fibronectin-fibrinogen cables for application in tissue engineering. Biotechnology and bioengineering, 2001. 73, 295-305. 
14. P. Rico, J.C. Rodríguez Hernández, D. Moratal, G. Altankov, M. Monleón Pradas, M. Salmerón-Sánchez. Substrate-Induced Assembly of Fibronectin into Networks: Influence of Surface Chemistry and Effect on Osteoblast Adhesion. Tissue Engineering: Part A, 2009. 15, 3271-3281.

15. D. Gugutkov, C. González-García, J.C. Rodríguez Hernández, G. Altankov, M. Salmerón-Sánchez. Biological Activity of the Substrate-Induced Fibronectin Network: Insight into the Third Dimension through Electrospun Fibers. - Langmuir, 2009. 25, 10893-10900.

16. R. Pankov, E. Cukierman, B.-Z. Katz, K. Matsumoto, D.C. Lin, S. Lin, C. Hahn, K.M. Yamada. Integrin Dynamics and Matrix Assembly: tensin-dependent translocation of alpha(5)beta(1) integrins promotes early fibronectin fibrillogenesis. The Journal of Cell Biology, 2000. 148, 1075-1090.

17. G. Altankov, T. Groth. Fibronectin matrix formation biocompatibility of materials. Journal of Materials Science: Materials in Medicine, 1996. 7, 425-429.

18. G. Altankov, T. Groth. Reorganization of substratum-bound fibronectin on hydrophilic and hydrophobic materials is related to biocompatibility. Journal of Materials Science: Materials in Medicine, 1994. 5, 732-737.

19. G. Altankov, F. Grinnell, T. Groth. Studies on the biocompatibility of materials: fibroblast reorganization of substratum-bound fibronectin on surfaces varying in wettability. Journal of biomedical materials research, 1996. 30, 385-391.

20. K.T. Preissner. Structure and biological role of vitronectin. Annual Review of Cell and Developmental Biology 1991. 7, 275-310.

21. C.D. Madsen, N. Sidenius. The interaction between urokinase receptor and vitronectin in cell adhesion and signalling. European Journal of Cell Biology, 2008. 87, 617-629.

22. M. Salmerón-Sánchez, P. Rico, D. Moratal, T.T. Lee, J.E. Schwarzbauer, A.J. García. Role of material-driven fibronectin fibrillogenesis in cell differentiation. Biomaterials, 2011. 32, 2099-2105.

23. N. Otsu. A Threshold Selection Method from Gray-Level Histograms. IEEE Transactions on Systems, Man, and Cybernetics, 1979. 9, 62-66.

24. G. Toromanov, C. González-García, G. Altankov, M. Salmerón-Sánchez. Vitronectin activity on polymer substrates with controlled $-\mathrm{OH}$ density. Polymer, 2010. 51, 2329-2336. 
25. D.J. Fabrizius-Homan, S.L. Cooper. Competitive adsorption of vitronection with albumin, fibrinogen, and fibronectin on polymeric biomaterials. Journal of Biomedical Materials Research, 1991. 25, 953-971.

26. Y. Mao, J.E. Schwarzbauer. Fibronectin fibrillogenesis, a cell-mediated matrix assembly process. Matrix Biology, 2005. 24, 389-399.

27. M. Leiss, K. Beckmann, A. Girós, M. Costell, R. Fässler. The role of integrin binding sites in fibronectin matrix assembly in vivo. Current Opinion in Cell Biology, 2008. 20, 502-507.

28. C. Werner, T. Pompe, K. Salchert. Modulating Extracellular Matrix at Interfaces of Polymeric Materials. in Polymers for Regenerative Medicine, C. Werner, Editor. 2006, Springer Berlin / Heidelberg: 63-93.

29. A. García. Interfaces to Control Cell-Biomaterial Adhesive Interactions. in Polymers for Regenerative Medicine, C. Werner, Editor. 2006, Springer Berlin / Heidelberg: 171-190.

30. M. Rabe, D. Verdes, S. Seeger. Understanding protein adsorption phenomena at solid surfaces. Advances in Colloid and Interface Science, 2011. 162, 87-106.

31. R.C. Chatelier,A.P. Minton. Adsorption of globular proteins on locally planar surfaces: models for the effect of excluded surface area and aggregation of adsorbed protein on adsorption equilibria. Biophysical Journal, 1996. 71, 23672374.

32. V. Ball, A. Lustig, J.J. Ramsden. Lag phases in the adsorption of lysozyme to $\mathrm{Si}(\mathrm{Ti}) \mathrm{O} 2$ surfaces in the presence of sodium thiocyanate. Part I. Phenomenology. Physical Chemistry Chemical Physics, 1999. 1, 3667-3671.

33. L.H. Sperling. Introduction to physical polymer science. J.W. Sons. 2001, New York, NY.

34. J.R. Retama, B. Lopez-Ruiz, E. Lopez-Cabarcos. Microstructural modifications induced by the entrapped glucose oxidase in cross-linked polyacrylamide microgels used as glucose sensors. Biomaterials, 2003. 24, 2965-2973.

35. X. Zhang, I. Burgar, M.D. Do, E. Lourbakos. Intermolecular Interactions and Phase Structures of Plasticized Wheat Proteins Materials. Biomacromolecules, 2005. 6, 1661-1671.

36. E.B. Stukalin, J.F. Douglas, K.F. Freed. Plasticization and antiplasticization of polymer melts diluted by low molar mass species. Journal of Chemical Physics, 2010. 132, 084504:084501-084511. 
37. P. Blasi, A. Schoubben, S. Giovagnoli, L. Perioli, M. Ricci, C. Rossi. Ketoprofen poly(lactide-co-glycolide) physical interaction. AAPS PharmSciTech, 2007. 8, E7885.

38. G. Altankov, T. Groth. Fibronectin matrix formation and the biocompatibility of materials. Journal of Materials Science: Materials in Medicine, 1996. 7, 425-429.

39. G. Altankov, F. Grinnell, T. Groth. Studies on the biocompatibility of materials: fibroblast reorganization of substratum-bound fibronectin on surfaces varying in wettability. Journal of Biomedical Materials Research, 1996. 30, 385-391.

40. R. Tzoneva, T. Groth, G. Altankov, D. Paul. Remodeling of fibrinogen by endothelial cells in dependence of fibronectin matrix assembly. Effect of substratum wettability. Journal of Materials Science: Materials Medicine, 2002. 13, 1235-1244.

41. M. Cantini, P. Rico, D. Moratal, M. Salmeron-Sanchez. Controlled wettability, same chemistry: biological activity of plasma-polymerized coatings. Soft Matter, 2012. 8, 5575-5584.

42. Y. Mao, J.E. Schwarzbauer. Stimulatory effects of a three-dimensional microenvironment on cell-mediated fibronectin fibrillogenesis. Journal of Cell Science, 2005. 118, 4427-4436.

43. E. Cukierman, R. Pankov, D.R. Stevens, K.M. Yamada. Taking Cell-Matrix Adhesions to the Third Dimension. Science, 2001. 294, 1708-1712.

44. J.L. Sechler, S.A. Corbett, M.B. Wenk, J.E. Schwarzbauer. Modulation of CellExtracellular Matrix Interactionsa. Annals of the New York Academy of Sciences, 1998. 857, 143-154.

45. I. Vlodavsky, G.M. Lui, D. Gospodarowicz. Morphological appearance, growth behavior and migratory activity of human tumor cells maintained on extracellular matrix versus plastic. Cell, 1980. 19, 607-616.

46. C. Wu, V.M. Keivenst, T.E. O'Toole, J.A. McDonald, M.H. Ginsberg. Integrin activation and cytoskeletal interaction are essential for the assembly of a fibronectin matrix. Cell, 1995. 83, 715-724.

47. R.J. Faull, J. Wang, D.I. Leavesley, W. Puzon, G.R. Russ, D. Vestweber, Y. Takada. A Novel Activating Anti-ß1 Integrin Monoclonal Antibody Binds to the Cysteine-rich Repeats in the $\beta 1$ Chain. Journal of Biological Chemistry, 1996. 271, 25099-25106.

48. D. Gugutkov, G. Altankov, J.C. Rodríguez Hernández, M. Monleón Pradas, M. Salmerón Sánchez. Fibronectin activity on substrates with controlled -OH density. Journal of Biomedical Materials Research Part A, 2010. 92A, 322-331. 


\section{Cell-mediated matrix remodeling at the nanoscale}

\section{Summary}

Early matrix reorganization in serum-free conditions on different acrylic polymers, PMA and PEA, is evaluated in this chapter. A change in the adsorbed FN layer, at the nanoscale, was observed by AFM after cell seeding on PEA surfaces, where $\mathrm{FN}$ was organized in a protein network. Different hypotheses were raised in order to investigate the cellular process that takes place in the first stages of cell adhesion. Collagen I secretion, evaluated by immunostaining, and matrix degradation, assessed by the enzymatic activity of MMP2 and 9 and immunostaining of MMP2, were excluded. We hypothesize that this effect might be caused by matrix degradation through the activity of other different MMPs or by endocytosis of the adsorbed FN. 



\subsection{Introduction}

Cellular interaction with ECM is highly dynamic in nature. In particular, cells are not only receiving information from specific cues in the ECM [1], but, simultaneously, and as consequence, cells respond to these inputs by remodeling the surrounding matrix and/or secreting new one [2-5]. Fibronectin is an important regulator of ECM remodeling; the deposition of several ECM molecules, including collagen type I and III, depends on the presence and stability of ECM fibronectin [6-7]. This ability of fibronectin to organize other proteins in the ECM is an important aspect of its function.

ECM remodeling is a dynamic process that consists of two opposite events: assembly and degradation. At least two mechanisms exist for the degradation and removal of proteins from the ECM: extracellular proteolysis [8-9] and endocytosis followed by intracellular degradation [10-13]. The proteolytic cleavage of ECM components represents a main mechanism for degradation and removal of the excess ECM [8-9]. The major enzymes that degrade ECM and cell surface associated proteins are MMPs, a family (24 members) of zinc dependent endopeptidases, which together with adamalysin-related membrane proteinases that contain disintegrin and metalloproteinase domains (ADAMs or MDCs), such as thrombin, tissue plasminogen activator (tPA), urokinase (UPA) and plasmin, are involved in the degradation of ECM proteins. MMPs are either secreted or anchored to the cell membrane by a transmembrane domain or by their ability to bind directly UPAR and integrin $\alpha_{v} \beta_{3}$ [14]. Pro-MMP is an inactivated form of MMPs which requires physical delocalization of the prodomain from the catalytic site for its activation. Most of the MMPs are secreted as proenzymes and their activation occurs in the pericellular and extracellular space. Matrix remodeling is subject of extensive biomedical research [15] but remodeling is poorly understood at the biomaterials level. Only a few examples in the literature have related the use of synthetic materials to the activity of MMPs [16-18]. 
Several works have investigated the cell-mediated matrix reorganization [1920], however, only a few reports have assessed the matrix reorganization at the nanoscale [21-22].

Atomic force microscopy (AFM) is a potential tool to evaluate biological processes at the molecular scale. It is a powerful experimental approach for the morphological characterization of cell adhesion [23-24]. Although fluorescence images of the F-actin provide information about the cytoskeleton development, the AFM allows to get high-resolution imaging of cellular structures [25]. Moreover, it offers the possibility of operating in aqueous solution, thus has great potential as a tool for imaging living cells in their physiological environments and for studying biologically important dynamic cellular processes in real time with molecular resolution [21]. In addition, AFM can be used to quantitatively measure mechanical properties of a cell [26-27].

AFM has been employed to investigate the conformation and distribution of proteins adsorbed onto a material surface [28-30], as well as the morphology of cells adhered onto material substrates [24]. However, very few studies have addressed the cell-mediated matrix reorganization at molecular level by using AFM [21-22]. In this work the cell-mediated FN reorganization is studied on PMA, PEA surfaces and glass control. It makes use of AFM to investigate the cell-mediated FN matrix reorganization at the nanoscale on PEA surfaces, where $\mathrm{FN}$ is organized in a protein network and the adsorbed protein layer is reorganized in a particular way. Different hypothesis are investigated seeking to explain the cellular processes that take place in the first stages of cell adhesion on this material. 


\subsection{Materials and methods}

\subsubsection{Preparation of films}

Polymer sheets were obtained by radical polymerization of a solution of the corresponding methyl (MA) and ethyl (EA) acrylate (Sigma-Aldrich) using 0.2 wt $\%$ benzoin ( $98 \%$ pure, Scharlau) as a photoinitiator. After polymerization, low molecular-mass substances were extracted from the material by drying in vacuo at $60^{\circ} \mathrm{C}$. Then, each of synthesized polymers was dissolved in toluene at a concentration of $2 \mathrm{wt} \%$. Thin films were prepared by spin casting of the polymer solutions on $12 \mathrm{~mm}$ glass coverslips at $2000 \mathrm{rpm}$ for $30 \mathrm{~s}$. Samples were dried in vacuo at $60{ }^{\circ} \mathrm{C}$ before further characterization. Glass coverslides were employed as a control.

\subsubsection{Atomic force microscopy}

Atomic force microscope was employed to analyze the surface of the substrates, the protein distribution on them and cell morphology.

AFM experiments were performed using a Multimode AFM equipped with NanoScope Illa controller from Veeco (Manchester, UK) operating in tapping mode in air. The Nanoscope 5.30r2 software version was used. Si-cantilevers from Veeco (Manchester, UK) were used with force constant of $2.8 \mathrm{~N} / \mathrm{m}$ and resonance frequency of $75 \mathrm{kHz}$. The phase signal was set to zero at a frequency $5-10 \%$ lower than the resonance one. Drive amplitude was $600 \mathrm{mV}$ and the amplitude setpoint $A_{s p}$ was $1.8 \mathrm{~V}$. The ratio between the amplitude setpoint and the free amplitude $A_{s p} / A_{0}$ was kept equal to 0.8 .

Samples were analyzed in the AFM, and height, phase and amplitude magnitudes were recorded simultaneously for each image. 


\subsubsection{Protein adsorption}

Fibronectin from human plasma (Sigma) was adsorbed on the different substrates by immersing the material sheets in several FN solutions at concentrations of 5 and $20 \mu \mathrm{g} / \mathrm{ml}$ in PBS for $10 \mathrm{~min}$. After adsorption, samples were rinsed in PBS to eliminate the non-adsorbed protein. The remaining drops on the surface were dried by exposing the sample to a nitrogen flow for 2-3 min. AFM was performed in the tapping mode immediately after sample preparation.

\subsubsection{Cell culture}

MC3T3-E1 cells were obtained from the RIKEN CELL BANK (Japan). Prior to seeding on $\mathrm{FN}$-coated substrates, cells were maintained in DMEM medium supplemented with $10 \%$ fetal bovine serum and $1 \%$ penicillin-streptomycin and passaged twice a week using standard techniques. Sample disks $(12 \mathrm{~mm}$ diameter) placed in a 24-well tissue culture plate were coated with FN 5 and 20 $\mu \mathrm{g} / \mathrm{ml}$ for $10 \mathrm{~min}$ and $1 \mathrm{~h}$. Then, $2 \cdot 10^{4}$ cells were placed onto each substrate (cell density: 10000 cells $/ \mathrm{cm}^{2}$ ) and were maintained at $37^{\circ} \mathrm{C}$ in a humidified atmosphere under $5 \% \mathrm{CO}_{2}$ for different time points: $30 \mathrm{~min}, 2 \mathrm{~h}$ and $48 \mathrm{~h}$. Each experiment was performed in triplicate.

\subsubsection{Cell morphology and protein reorganization by AFM}

The AFM was also employed to assess, at the nanoscale, the cell morphology and the protein distribution onto the substrate after cell seeding. For that, after 30 min of culture, cells were washed in Dulbecco's phosphate buffered saline (DPBS, Invitrogen) and fixed in Formalin solution 10\% (Sigma) at $4{ }^{\circ} \mathrm{C}$ for $30 \mathrm{~min}$. Remaining drops of DPBS on the sample surface were gently dried by exposing the sample to a nitrogen flow for 2-3 min. Cell morphology and the protein distribution onto the substrate surfaces were evaluated by AFM working in the tapping mode in air environment, immediately after sample preparation. 


\subsubsection{Immunofluorescence}

The ability of cells to reorganize adsorbed FN (i.e. early matrix) was monitored after coating all samples with 5 and $20 \mu \mathrm{g} / \mathrm{ml} \mathrm{FN}$ solutions and rinsing with PBS twice before seeding cells in serum-free conditions. The synthesis of collagen I (after $30 \mathrm{~min}$ of culture) and matrix metalloproteinase-2 (after $30 \mathrm{~min}$ and $2 \mathrm{~h}$ of culture) by MC3T3-E1 osteoblastic-like cells was investigated.

At the end of incubation time, cells were washed in Dulbecco's phosphate buffered saline (DPBS, Invitrogen) and fixed in 10\% formalin solution (Sigma) at $4{ }^{\circ} \mathrm{C}$ for 30 min (for FN and MMP-2 detection), and fixed in formaldehyde solution $3.7 \%$ (Sigma) at room temperature for $15 \mathrm{~min}$ (for Col I detection). Samples were rinsed with DPBS and the permeabilization buffer was added at room temperature for $5 \mathrm{~min}$. In order to reduce the background signal, the samples were then incubated in 1\% BSA/DPBS at room temperature for $30 \mathrm{~min}$. Samples were incubated with primary antibody against FN (polyclonal rabbit; $1: 400$, Sigma), or Col I (monoclonal mouse; 1:400, Sigma), or MMP2 (polyclonal rabbit; $2 \mu \mathrm{g} / \mathrm{ml}$, Sigma) in 1\% BSA/DPBS at room temperature for 1 h. The samples were rinsed in $0.5 \%$ Tween 20/DPBS three times for 5 min each and the appropriate anti-rabbit or anti-mouse Cy3-conjugated secondary antibody (1:200 in 1\% BSA/DPBS, Invitrongen) was incubated at room temperature for $1 \mathrm{~h}$. Simultaneously, BODIPY FL phallacidin was added for the duration of this incubation (1:40 in 1\% BSA/PBS; Invitrogen). Finally, samples were washed in $0.5 \%$ Tween 20/DPBS three times before mounted in Vectashield containing DAPI (Vector Laboratories, Peterborough, UK). A Nikon fluorescence microscope was used for cellular imaging.

\subsubsection{Zymography}

In order to detect active and pro-matrix metalloproteinases (gelatinases MMP2 and 9) secreted by cells, MC3T3-E1 cells were cultures on each material for different culture times in serum-free conditions. Then, the supernatants were 
subjected to $10 \%$-SDS polyacrylamide gel electrophoresis (PAGE) containing $0.1 \%$ gelatin (Biorad), using a loading buffer $2 \times(62.5 \mathrm{mM}$ Tris- $\mathrm{HCl} \mathrm{pH} 6.8,25 \%$ glycerol, $4 \%$ SDS, $0.01 \%$ bromophenol blue) and denaturing standard conditions. A prestained marker was employed to control the electrophoresis time. Afterwards, gelatin gel was incubated in renaturation buffer $(2.5 \%$ Triton $\mathrm{X}-100 / \mathrm{H}_{2} \mathrm{O}$ ) at room temperature for $30 \mathrm{~min}$ to remove the SDS and thus, the proteinase activity was retrieved. Then, gel was incubated in a development buffer (50mM base Tris, $200 \mathrm{mM} \mathrm{NaCl}, 5 \mathrm{mM}$ anhydrous $\mathrm{CaCl}_{2}, 0.02 \% 30 \%$ brij-35) overnight at $37^{\circ} \mathrm{C}$. The enzymatic activity was revealed by staining the gel at room temperature with a solution containing $0.5 \%$ Coomassie $(40 \%$ methanol, $10 \%$ acetic acid, $0.5 \%$ Coomassie R-250) and, subsequently, a destaining solution ( $40 \%$ methanol, $10 \%$ acetic acid) was added at room temperature to detect the bands. The bands were visualized with a Molecular Imager Gel Doc XR+ transilluminator (Imaging System, BioRad) and were analyzed with Image $\mathrm{J}$.

\subsubsection{Live/Dead viability assay}

MC3T3-E1 cells were incubated for different culture times on FN-coated substrates in serum-free conditions. Then, cells were incubated for $15 \mathrm{~min}$ with $300 \mu \mathrm{l}$ of combined Live/Dead assay reagents, using the concentrations recommended by the manufacturer: $2 \mu \mathrm{M}$ calcein $\mathrm{AM}$ and $4 \mu \mathrm{M}$ Ethidium homodimer-1 (EthD-1, Molecular Probes, Inc, Eugene, OR). All the labelled cells were visualized under a fluorescence microscope. Viable green fluorescent cells and dead red fluorescent cells were counted in ten different fields, and the percent of dead cells was calculated $(n \geq 15)$. The experiment was performed in triplicate and the results were averaged. 


\subsection{Results and discussion}

\subsubsection{FN distribution}

FN distribution on PMA and PEA surfaces before seeding cells was assessed by AFM. Figure 7.1 shows phase images of the FN adsorbed from protein solutions of 5 and $20 \mu \mathrm{g} / \mathrm{ml}$ for $10 \mathrm{~min}$. Isolated globular protein molecules are homogeneously distributed on PMA when FN is adsorbed from 5 $\mu \mathrm{g} / \mathrm{ml}$, whereas interconnected protein molecules give rise to an incipient $\mathrm{FN}$ network on PEA surface. For a higher concentration $(20 \mu \mathrm{g} / \mathrm{ml})$, FN molecules formed aggregates on PMA, however a well-interconnected FN network is observed on PEA. Glass coverslides were employed as a control, and the FN distribution on this hydrophilic surface is also shown in Figure 7.1. FN molecules adopted a globular form and were distributed in aggregates along the glass surface.

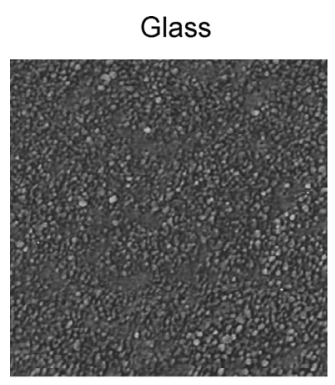

$1 \mu \mathrm{m}$
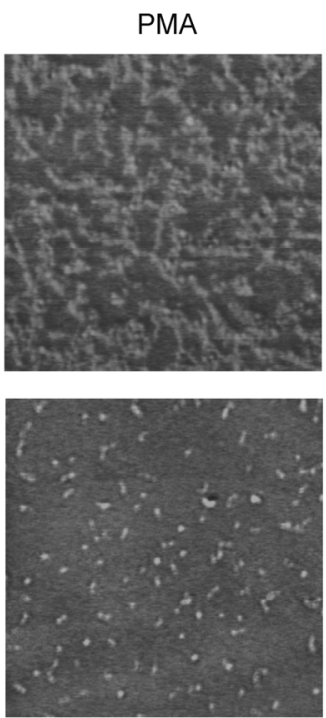
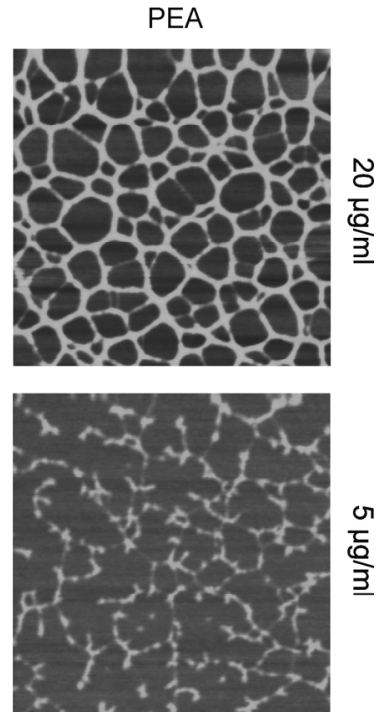

\section{음}

G

$\stackrel{\frac{\tau}{0}}{\underline{3}}$

Figure 7.1 Fibronectin distribution on the different substrates as observed by the phase magnitude in AFM. The protein was adsorbed for $10 \mathrm{~min}$ from solutions of 5 and 20 $\mu \mathrm{g} / \mathrm{ml}$. 


\subsubsection{Cell-mediated FN reorganization}

Cell-mediated FN reorganization on the different substrates was assessed in serum-free conditions. Figure 7.2 shows the cellular reorganization of the FN adsorbed from solutions of 5 and $20 \mu \mathrm{g} / \mathrm{ml}$, after different cultures times (30 min and $2 \mathrm{~h}$ ), as observed by fluorescence images. Rounded cell morphology is observed after adhesion for 30 min (third row), whereas cells are able to spread better on the different substrates after longer times, regardless the FN concentration employed for the protein coating (first and second rows). On the different materials FN staining was higher when the protein was adsorbed from a $5 \mu \mathrm{g} / \mathrm{ml}$ solution.

It is important to note that MC3T3-E1 cells were seeded in serum-free conditions. It is known that the presence of other proteins (e.g. vitronectin or albumin) are necessary for the FN reorganization to take place [19-20]. This fact may explain the scarce traces of $\mathrm{FN}$ reorganization observed in the different substrates. Surprisingly, a brighter area around adherent cells was only observed on PEA surfaces, regardless the initial concentration from which FN was adsorbed and the different culture times. 


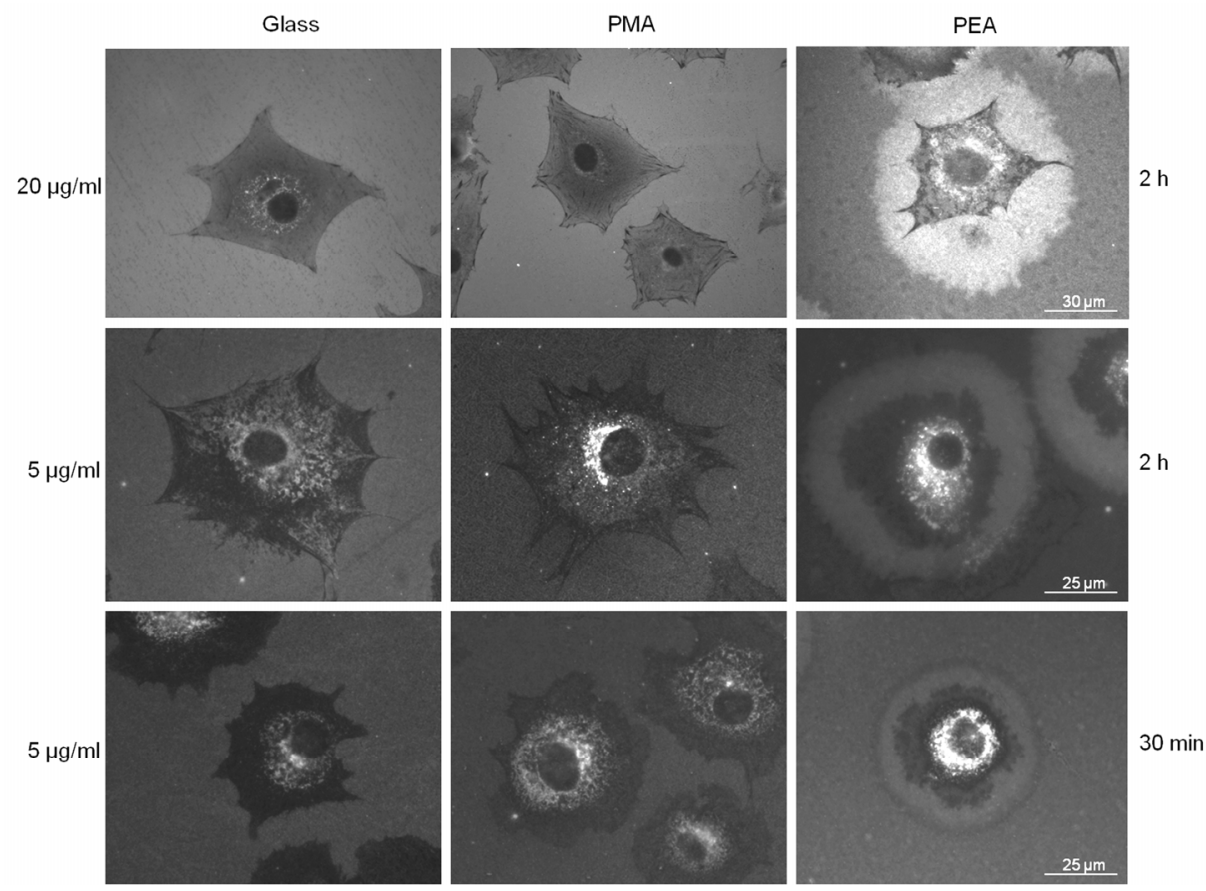

Figure 7.2 Staining of adsorbed FN from solutions of 5 and $20 \mu \mathrm{g} / \mathrm{ml}$ on PMA, PEA and glass control, after different culture times.

The brighter area observed around cells growing on PEA surfaces was also investigated by making use of the AFM in tapping mode, in order to detect, at the nanoscale, any change in the distribution of the adsorbed FN. MC3T3-E1 cells were adhered on FN-coated PEA surfaces for 30 min. A short culture time was chosen in order to assess the observed phenomenon at the initial stages. Figure 7.3 shows AFM height and phase images, at different scales (from 60 to $5 \mu \mathrm{m}$ window), of two different cells adhered on PEA surface. The 3D reconstruction of the cells can be observed at the bottom of the figure. 


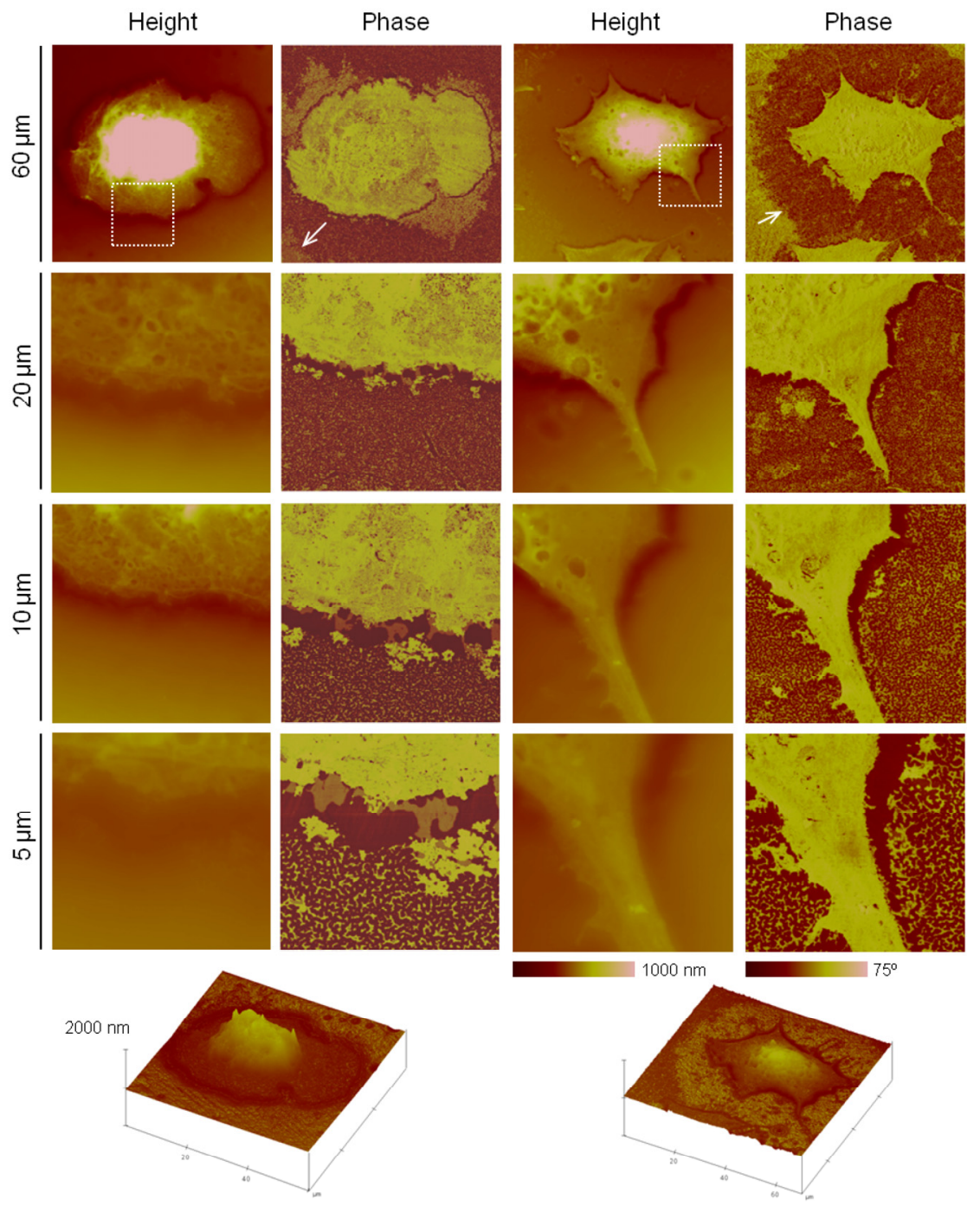

Figure 7.3 Cell morphology and FN distribution after 30 min of cell seeding on PEA surfaces as observed by height and phase magnitudes in the AFM. The inset squares in first row represent the detailed area at different magnification in the rest of the images and the arrows point out a change on the FN distribution. A $3 D$ reconstruction of the cells is observed at the bottom of the figure. 
Cell morphology can be observed in height images at different scales, and also in the 3D reconstruction of these images, where the height of the spread cell on the substrate is clearly observed. On the other hand, the protein distribution on the surface can be visualized in the phase images. At higher scale (first row), a change in the distribution of the adsorbed $\mathrm{FN}$ layer is identified in the phase images, as the arrows in Figure 7.3 point out. When the cell edge is scanned at lower scales, FN distribution around cells can be visualized, mainly in the $5 \mu \mathrm{m}$ window, and interconnected protein molecules can be observed. On the other hand, the interface where a shift in the conformation of the adsorbed FN takes place was scanned at different scales, as shown in Figure 7.4a. The distribution of the adsorbed protein was altered in areas close to cells regarding the protein distribution in areas between cells, as better indentified at higher magnitude in Figure 7.4b. While some interconnected protein molecules can be observed around cells, a dense FN network is observed far away from cells suggesting a cell-mediated remodeling of the closer protein matrix. 


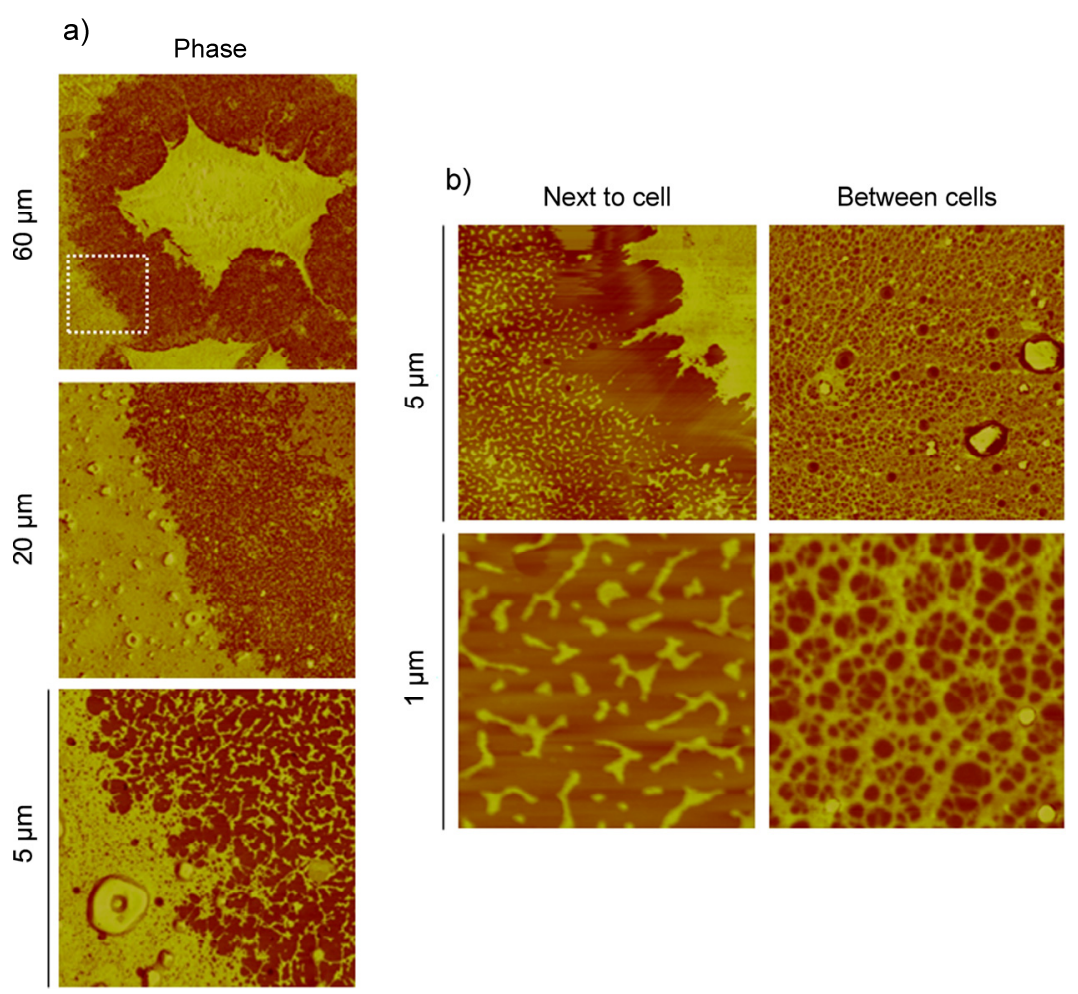

Figure 7.4 Cellular reorganization, at the nanoscale, of the FN adsorbed on PEA surface, as observed by the phase image in the AFM. a) Interface observed in the protein layer, b) FN distribution next to cells and between cells.

It is important to point out that differences in $\mathrm{FN}$ distribution are found both close to and between cells (i.e. the area of the substrate where any cell has been adhered) when comparing the FN distribution on PEA surfaces before and after cell seeding (Figure 7.1 and Figure 7.4). After cell culture, the arms of the interconnected FN molecules observed on the cell-free substrate, become thicker on the area next to spread cells. However, a dense FN network is formed on areas in between cells.

These results suggest that some cellular remodeling of the adsorbed FN, even in serum-free conditions, is taking place in the initial stages of cell adhesion. Since cells are able to alter the distribution of the adsorbed FN layer 
on this material in a particular way, several hypotheses were therefore raised in order to further investigate the cellular processes that are occurring, as discussed afterwards.

\section{$\underline{\text { Collagen I secretion }}$}

The higher density of assembled protein found on areas between cells in AFM images suggests the secretion of new matrix. However, no traces of secreted or reorganized FN were observed far away from cells, since no changes in fluorescence levels were found when FN was detected with antibodies. Moreover, the brighter area around cells (Figure 7.2) could indicate a higher amount of FN next to cell, however, a lower density of FN in that area was found in AFM images (Figure 7.4). Therefore, the secretion of other ECM proteins and their posterior degradation is suggested.

MC3T3-E1 osteoblast-like cells are able to produce collagen type I (Col I) when cell differentiation takes place [31]. Moreover, the deposition and assembly of several ECM molecules, including collagen I, depends on the presence of an organized fibrillar fibronectin matrix (i.e. a pre-existing $\mathrm{FN}$ network can induce the collagen I assembly) [6, 32]. Therefore, the denser protein network found between cells could be due to the collagen matrix formation. In that case, the lost of protein in areas next to cells could be due to the endocytosis of collagen I, which is regulated by FN polymerization, as previously shown [32]. So, the ability of MC3T3-E1 cells to secrete collagen I was assessed by immunostaining. Figure 7.5 shows the cellular secretion of Col $\mathrm{I}$ at different magnifications after cell seeding on FN-coated substrates for 30 min. Cells growing on PEA surfaces were able to synthesize Col I, as observed in the Figure 7.5 , where the collagen I is only observed within cell area and no traces of Col I are observed between cells. 


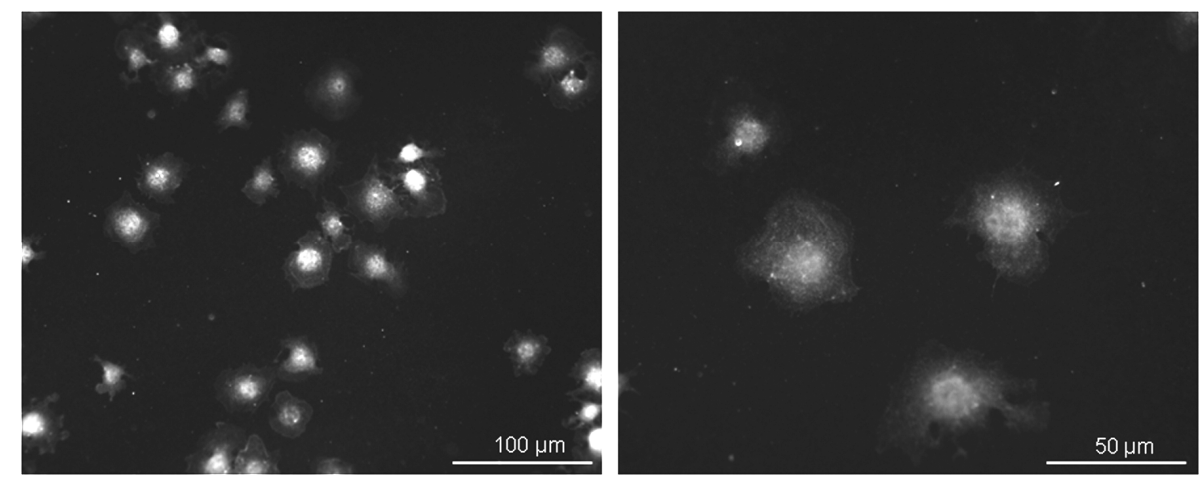

Figure 7.5 Synthesis of collagen I by MC3T3-E1 osteoblast-like cells cultured on PEA surfaces for $30 \mathrm{~min}$, at different magnifications.

Nevertheless, the low levels of secreted Col I found are reasonable and somehow expected, since a short time of culture has been studied [33]. The lack of Col I observed between cells rules out the idea that the denser protein network is due to the secretion and assembly of Col I. The secretion of other matrix protein was not raised, since MC3T3-E1 cells were incubated for a short time of culture and collagen I is the most characteristic protein synthesized by this cell type [5, 33].

\section{Matrix degradation}

The high levels of fluorescence around adherent cells on PEA, observed in Figure 7.2, suggest a higher FN density, however, a less interconnected FN network was found in these areas in AFM images (Figure 7.4). This also suggests that proteolytic activity could take place in areas around cells, and more accessible binding sites for antibodies could be present in the degraded protein and, consequently, the levels of fluorescence be higher. Moreover, it has been recently demonstrated that the pre-existent FN network on PEA induces the proteolytic degradation process, compared to the degradation of the globular FN on PMA [34]. 
The ability of cells to degrade the ECM, after contact by cell movements or by the release and diffusion of proteinases, was investigated by characterizing the enzymatic activity of two different matrix metalloproteinases, MMP2 and MMP9 (gelatinases), on the different materials. The results of the gelatin zimography in Figure 7.6a show the proteolitic activity of MMP2 and MMP9 and their various forms (MMP2, pro-MMP2, MMP9 and pro-MMP9) after $2 \mathrm{~h}$ of culture on the different materials coated with $\mathrm{FN}$ at $5 \mu \mathrm{g} / \mathrm{ml}$. A protein coating of $20 \mu \mathrm{g} / \mathrm{ml}$ was also employed to study the enzymatic activity on PEA. Similar activity of both MMP2 and MMP9 was found on the different substrates and the levels on PEA surfaces were similar regardless the concentration of the protein coating. On the other hand, the synthesis of MMP2 was investigated by immunostaning after different culture times on PEA surfaces, seeking to assess whether this proteinase was preferably localized on the brighter areas, where the matrix degradation is hypothesized. As shown in Figure 7.6b, MMP2 was synthesized by cells growing on PEA and glass surfaces, however there are not traces of this protein around cells, probably due to its removal from the surfaces during washes in the followed protocol for immunostaining. 
a)

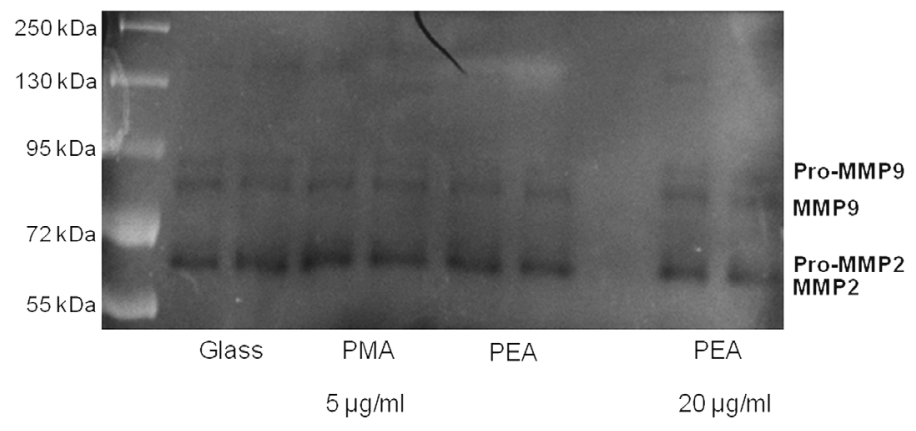

b)

Glass

MMP2

PEA

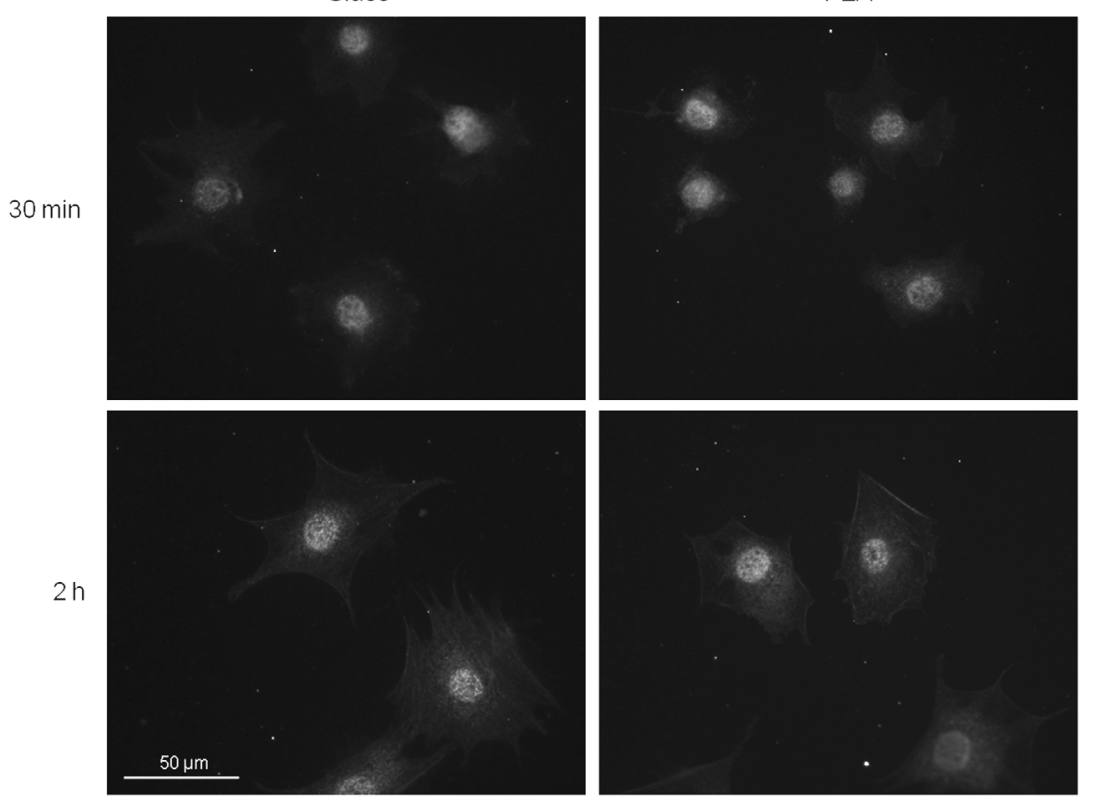

Figure 7.6 Matrix proteolitic degradation by MC3T3-E1 osteoblastic-like cells. a) Gelatin zimography showing the activity of MMP2 and 9, and their various forms (MMP2, proMMP2, MMP9 and pro-MMP9). b) MMP2 in cells growing on PEA and glass. Glass was employed as a control.

Since there are not differences in the proteolytic activity of MMP2 and MMP9 on the different substrates coated with FN $5 \mu \mathrm{g} / \mathrm{ml}$ (Figure 7.6a), higher matrix degradation on PEA surfaces cannot be concluded. It is possible that other 
differences in their activity on the different materials might be observed, since the extended FN conformation on PEA surfaces might expose specific cleavage sites which are hidden on FN adsorbed on PMA surfaces. Therefore the proteolytic degradation by other MMPs should be investigated before excluding the degradation of the FN layer. In fact, it has been shown that MMP1 is crucial to regulate the fibronectin remodeling by promoting extracellular cleavage of this protein [35].

On the other hand, the endocytosis followed by intracellular degradation is other mechanism of degradation and removal of proteins from the ECM [10-12]. Concretely, previous data have shown that endocytosis is a major mechanism that regulates turnover of ECM fibronectin $[13,36]$ and is regulated by $\beta_{1}$ integrins, including $\alpha_{5} \beta_{1}$. It has also been shown that FN cleavage by MMP1 is necessary for its efficient endocytosis [35]. So, further experiments should be done to investigate a possible protein endocytosis induced by this material.

\subsection{Cell viability and cell proliferation}

Despite the fact that PEA substrates have been employed in numerous studies on which good cell response of different cell types has been shown [3740], cytotoxicity assays and cell proliferation studies were performed in order to exclude any apoptotic signal secreted by cells as the cause of changes in FN layer on PEA surfaces. Figure 7.7a) shows the results of live/dead assay, where $11 \%$ of cell dead is observed after 30 min of culture on PEA, compared to $2 \%$ in PMA surfaces. However, after $2 \mathrm{~h}$ of culture no dead cells were found on both substrates. Cell viability on glass was also high, since no dead cells were found.

Cell proliferation on the different substrates was evaluated after $2 \mathrm{~h}$ and $48 \mathrm{~h}$ of culture. A lower proliferation rate was observed on PMA and PEA surfaces comparing to glass. However, small differences in cell proliferation were found between both polymers. 
a)

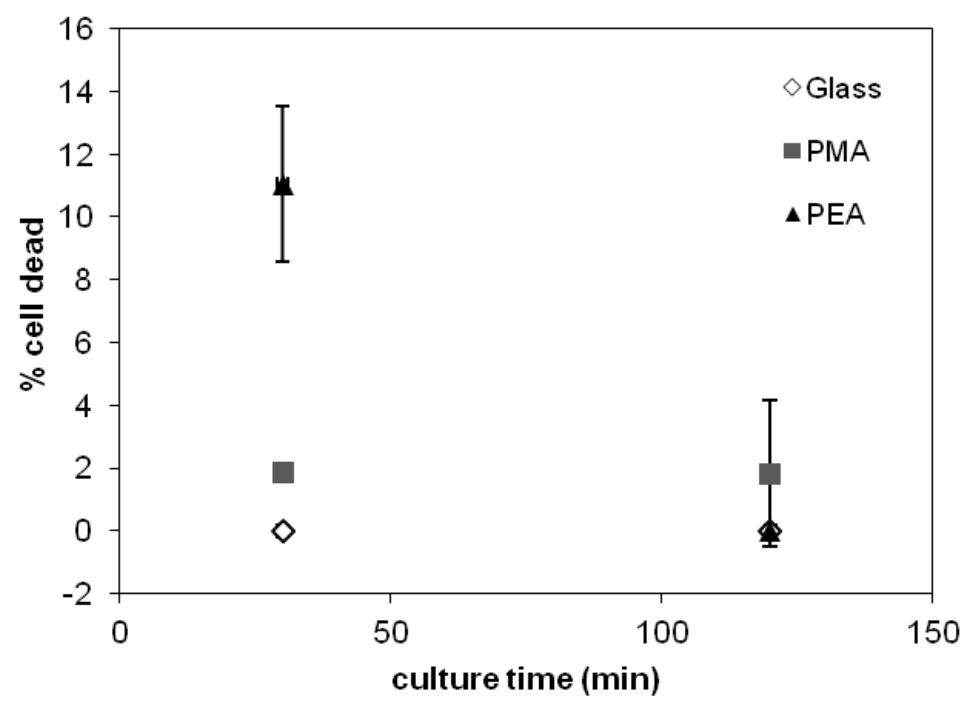

b)

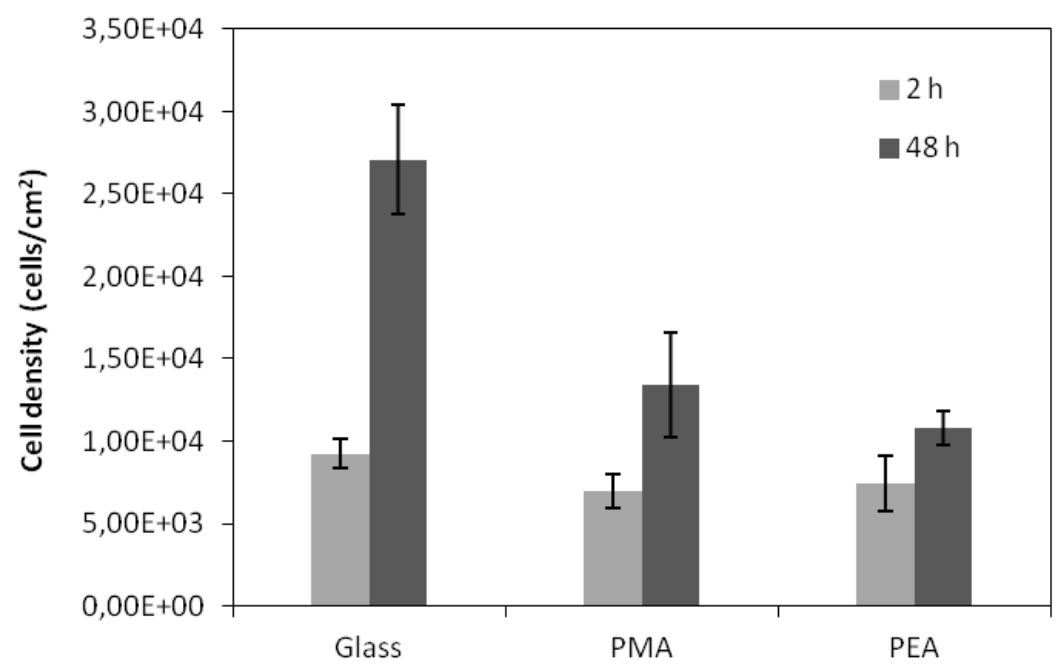

Figure 7.7 a) Cell viability and b) cell proliferation of MC3T3-E1 cells growing on PMA, PEA substrates and glass control for different culture times.

Since a very low percent of dead cells were found after 30 min of culture on PEA surfaces and no dead cells were found after $2 \mathrm{~h}$, the non-cytotoxicity of PEA was verified. Moreover, cells were able to proliferate after adhesion on this 
material. Therefore, further experiments should be done to determine the cellular processes that are taking place during matrix remodeling when MC3T3E1 cells adhere on this material.

\subsection{Conclusions}

Early matrix remodeling was investigated in serum-free conditions on substrates on which FN adopts different conformations. Surprisingly on PEA surfaces, where a FN network is formed, a change in the adsorbed FN layer both close to cells and in between cells- was observed by AFM at the nanoscale after cell adhesion. Thus, different hypotheses were raised in order to investigate the cellular processes occurring in the first stages of cell adhesion on PEA surfaces.

Concretely, collagen I secretion was investigated in order to explain the denser protein mesh observed far away from cells, since collagen $\mathrm{I}$ is synthesized by MC3T3-E1 cells when their differentiation takes place. However, as no traces of this protein were found in between cells, this hypothesis was excluded. Matrix degradation was also assessed on the different materials due to the lower FN density observed around cells on PEA surfaces. Nevertheless, no differences were found in the enzymatic activity of MMP2 and MMP9 on the different materials. Since the non-cytotoxicity of PEA surfaces was also verified, other approaches such as the matrix remodeling by other matrix metalloproteinases or endocytosis of the protein should be investigated to further investigate this phenomenon. 


\subsection{References}

1. G. Altankov, T. Groth. Reorganization of substratum-bound fibronectin on hydrophilic and hydrophobic materials is related to biocompatibility. Journal of Materials Science: Materials in Medicine, 1994. 5, 732-737.

2. F. Grinnell. Focal adhesion sites and the removal of substratum-bound fibronectin. The Journal of Cell Biology, 1986. 103, 2697-2706.

3. R.O. Hynes. Integrins: Bidirectional, Allosteric Signaling Machines. Cell, 2002. 110, 673-687.

4. Z. Avnur, B. Geiger. The removal of extracellular fibronectin from areas of cellsubstrate contact. Cell, 1981. 25, 121-132.

5. T.A. Owen, M. Aronow, V. Shalhoub, L.M. Barone, L. Wilming, M.S. Tassinari, M.B. Kennedy, S. Pockwinse, J.B. Lian, G.S. Stein. Progressive development of the rat osteoblast phenotype in vitro: reciprocal relationships in expression of genes associated with osteoblast proliferation and differentiation during formation of the bone extracellular matrix. Journal of Cellular Physiology, 1990. 143, 420-430.

6. J. Sottile, D.C. Hocking. Fibronectin Polymerization Regulates the Composition and Stability of Extracellular Matrix Fibrils and Cell-Matrix Adhesions. Molecular Biology of the Cell, 2002. 13, 3546-3559.

7. T. Velling, J. Risteli, K. Wennerberg, D.F. Mosher, S. Johansson. Polymerization of Type I and III Collagens Is Dependent On Fibronectin and Enhanced By Integrins $\alpha 11 \beta 1$ and $\alpha 2 \beta 1$. Journal of Biological Chemistry, 2002. 277, 37377-37381.

8. J.E. Koblinski, M. Ahram, B.F. Sloane. Unraveling the role of proteases in cancer. Clinica Chimica Acta, 2000. 291, 113-135.

9. M.M. Mohamed, B.F. Sloane. Cysteine cathepsins: multifunctional enzymes in cancer. Nature Reviews. Cancer, 2006. 6, 764-775.

10. L. East, A. McCarthy, D. Wienke, J. Sturge, A. Ashworth, C.M. Isacke. A targeted deletion in the endocytic receptor gene Endo180 results in a defect in collagen uptake. EMBO, 2003. 4, 710-716.

11. T.M. Odrljin, C.G. Haidaris, N.B. Lerner, P.J. Simpson-Haidaris. Integrin $\alpha \vee \beta 3$ Mediated Endocytosis of Immobilized Fibrinogen by A549 Lung Alveolar Epithelial Cells. American Journal of Respiratory Cell and Molecular Biology, 2001. 24, 1221. 
12. T.S. Panetti, S.A. Wilcox, C. Horzempa, P.J. McKeown-Longo. Integrin Receptormediated Endocytosis of Vitronectin Is Protein Kinase C-dependent. Journal of Biological Chemistry, 1995. 270, 18593-18597.

13. J. Sottile, J. Chandler. Fibronectin Matrix Turnover Occurs through a Caveolin-1dependent Process. Molecular Biology of the Cell, 2005. 16, 757-768.

14. M.R. Buck, D.G. Karustis, N.A. Day, K.V. Honn, B.F. Sloane. Degradation of extracellular-matrix proteins by human cathepsin $B$ from normal and tumour tissues. The Biochemical journal, 1992. 282, 273-278.

15. A. Page-McCaw, A.J. Ewald, Z. Werb. Matrix metalloproteinases and the regulation of tissue remodelling. Nat Rev Mol Cell Biol, 2007. 8, 221-233.

16. C.-M. Yang, C.-S. Chien, C.-C. Yao, L.-D. Hsiao, Y.-C. Huang, C.B. Wu. Mechanical strain induces collagenase-3 (MMP-13) expression in MC3T3-E1 osteoblastic cells. The Journal of biological chemistry, 2004. 279, 22158-22165.

17. R. Wan, Y. Mo, X. Zhang, S. Chien, D.J. Tollerud, Q. Zhang. Matrix metalloproteinase-2 and -9 are induced differently by metal nanoparticles in human monocytes: The role of oxidative stress and protein tyrosine kinase activation. Toxicology and applied pharmacology, 2008. 233, 276-285.

18. V. Llopis, P. Rico, J. Ballester, D. Moratal, M. Salmerón-Sánchez. Role of surface chemistry in protein remodelling at the cell-material interface. Plos one, 2011.

19. G. Altankov, V. Thom, T. Groth, K. Jankova, G. Jonsson, M. Ulbricht. Modulating the biocompatibility of polymer surfaces with poly(ethylene glycol): Effect of fibronectin. Journal of Biomedical Materials Research, 2000. 52, 219-230.

20. G. Altankov, T. Groth. Fibronectin matrix formation and the biocompatibility of materials. Journal of Materials Science: Materials in Medicine, 1996. 7, 425-429.

21. J. Friedrichs, A. Taubenberger, C.M. Franz, D.J. Muller. Cellular Remodelling of Individual Collagen Fibrils Visualized by Time-lapse AFM. Journal of Molecular Biology, 2007. 372, 594-607.

22. K.L. De Jong, H.C. MacLeod, P.R. Norton, N.O. Petersen. Fibronectin organization under and near cells. European Biophysics Journal, 2006. 35, 695-708.

23. A. Simon, M.-C. Durrieu. Strategies and results of atomic force microscopy in the study of cellular adhesion. Micron, 2006. 37, 1-13.

24. D. Docheva, D. Padula, M. Schieker, H. Clausen-Schaumann. Effect of collagen I and fibronectin on the adhesion, elasticity and cytoskeletal organization of prostate cancer cells. Biochemical and biophysical research communications, 2010. 402, 361-366. 
25. J.A. Dvorak. The application of atomic force microscopy to the study of living vertebrate cells in culture. Methods, 2003. 29, 86-96.

26. Q. Guo, Y. Xia, M. Sandig, J. Yang. Characterization of cell elasticity correlated with cell morphology by atomic force microscope. Journal of Biomechanics, 2012. 45, 304-309.

27. Q.S. Li, G.Y.H. Lee, C.N. Ong, C.T. Lim. AFM indentation study of breast cancer cells. Biochemical and biophysical research communications, 2008. 374, 609-613.

28. T. Ballet, L. Boulange, Y. Brechet, F. Bruckert, M. Weidenhaupt. Protein conformational changes induced by adsorption onto material surfaces : an important issue for biomedical applications of material science. Bulletin Of The Polish Academy Of Sciences Technical Sciences, 2010. 58, 303-315.

29. D.R. Schmidt, H. Waldeck, W.J. Kao. Protein Adsorption to Biomaterials. D.A. Puleo,R. Bizios, Editor. 2009, 1-18.

30. T.S. Tsapikouni, Y.F. Missirlis. $\mathrm{pH}$ and ionic strength effect on single fibrinogen molecule adsorption on mica studied with AFM. Colloids and surfaces. B, Biointerfaces, 2007. 57, 89-96.

31. J.S. Johansen, M.K. Williamson, J.S. Rice, P.A. Price. Identification of proteins secreted by human osteoblastic cells in culture. Journal of Bone and Mineral Research, 1992. 7, 501-512.

32. F. Shi, J. Harman, K. Fujiwara, J. Sottile. Collagen I matrix turnover is regulated by fibronectin polymerization. American Journal of Physiology - Cell Physiology, 2010. 298, C1265-C1275.

33. J.-Y. Choi, B.-H. Lee, K.-B. Song, R.-W. Park, I.-S.-. Kim, K.-Y. Sohn, J.-S. Jo, H.M. Royoo. Expression patterns of bone-related proteins during osteoblastic differentiation in MC3T3-E1 cells. Journal of Cellular Biochemistry, 1996. 61, 609618.

34. V. Llopis-Hernández, P. Rico, D. Moratal, M. Salmerón Sánchez. Role of materialdriven fibronectin fibrillogenesis in matrix remodeling. Matrix biology, 2012. Submitted.

35. F. Shi, J. Sottile. MT1-MMP regulates the turnover and endocytosis of extracellular matrix fibronectin. Journal of Cell Science, 2011. 124, 4039-4050.

36. F. Shi, J. Sottile. Caveolin-1-dependent $\beta 1$ integrin endocytosis is a critical regulator of fibronectin turnover. Journal of Cell Science, 2008. 121, 2360-2371.

37. P. Rico, J.C. Rodríguez Hernández, D. Moratal, G. Altankov, M. Monleón Pradas, M. Salmerón-Sánchez. Substrate-Induced Assembly of Fibronectin into Networks: 
Influence of Surface Chemistry and Effect on Osteoblast Adhesion. Tissue Engineering: Part A, 2009. 15, 3271-3281.

38. D. Gugutkov, C. González-García, J.C. Rodríguez Hernández, G. Altankov, M. Salmerón-Sánchez. Biological Activity of the Substrate-Induced Fibronectin Network: Insight into the Third Dimension through Electrospun Fibers. - Langmuir, 2009. 25, 10893-10900.

39. D. Gugutkov, G. Altankov, J.C. Rodríguez Hernández, M. Monleón Pradas, M. Salmerón Sánchez. Fibronectin activity on substrates with controlled -OH density. Journal of Biomedical Materials Research Part A, 2010. 92A, 322-331.

40. M. Salmerón-Sánchez, P. Rico, D. Moratal, T.T. Lee, J.E. Schwarzbauer, A.J. García. Role of material-driven fibronectin fibrillogenesis in cell differentiation. Biomaterials, 2011. 32, 2099-2105. 

8. Conclusions 

The influence of material properties on fibronectin response, in term of adsorbed amount and conformation, has been investigated on different sets of materials with tailored physico-chemical properties. The effect of these properties on early cell response and cellular functionality has been investigated and correlated to the state of the fibronectin adsorbed onto the material.

The main findings extracted from this thesis are presented below.

\section{1) Nanoscale topography influences fibronectin adsorption and cell response.}

The effect of nanotopography on FN adsorption and cell behavior was investigated using PLLA/PS nanotopographies of different sizes.

FN adsorption depends on the size of the nanostructure, i.e. the amount of adsorbed $\mathrm{FN}$ is higher on the $14 \mathrm{~nm}$ deep substrate than on the other two ones (29 and $45 \mathrm{~nm}$ deep pits). Protein conformation and distribution between valleys and peaks is similar when $\mathrm{FN}$ adsorption takes place from solutions of concentration of $10 \mu \mathrm{g} / \mathrm{ml}$ or higher (thus including the concentration employed in cell cultures, $20 \mu \mathrm{g} / \mathrm{ml}$ ).

The distribution of focal adhesions (vinculin) is strongly affected by the size of the nanopits. Focal adhesion plaques are too small in $14 \mathrm{~nm}$ deep pit nanotopographies, so that even if cells are able to adhere on the substrate and they develop the actin cytoskeleton, there is no trace of reorganization for the adsorbed FN layer. In the long term, this leads to diminished functionality in the formation of the new matrix. In nanotopographies with higher deep pits (29 and $45 \mathrm{~nm}$ ), where focal adhesion plaques are more developed, the adsorbed FN layer is more reorganized, which results in higher secretion and organization of new FN matrix. 


\section{2) Surface mobility regulates cell adhesion and skeletal stem cell differentiation.}

The system based on a vinyl chain with the side groups $-\mathrm{COO}\left(\mathrm{CH}_{2}\right)_{x} \mathrm{H}$, where $x=1,2,4$, allows assessment of the influence of minute variations in surface chemistry in protein adsorption, cell adhesion and cell differentiation.

Transition from $x=1$ (PMA) to $x=2$ (PEA) drastically alters $F N$ distribution at the cell-material interface, from a globular form on PMA to the formation of a well-interconnected FN network on PEA, such that other physical parameters of the matrix (e.g. stiffness) do not play any role in cell response. Surface mobility is higher on $x=4(P B A)$ than $x=2(P E A)$, as quantified by the glass transition temperature of the system, which led to a faster dynamics in FN network formation and enhanced cell adhesion and differentiation of mesenchymal stem cells to the osteoblastic lineage. Thus, this study identifies surface mobility, and its quantification by the glass transition temperature, as a new physical parameter of the matrix able to direct skeletal stem cell differentiation.

Our findings indicate the potential to modulate stem and progenitor cell commitment along desired lineages through surface mobility of the underlying material surface.

\section{3) Vitronectin influences fibronectin adsorption and cell-mediated fibronectin reorganization.}

The role of vitronectin (VN) on fibronectin (FN) adsorption and cellular response on PEA surfaces has been investigated.

On this material substrate, PEA, where FN is organized into well developed, physiological-like networks, the presence of $\mathrm{VN}$ enhances $\mathrm{FN}$ adsorption. Higher amount of FN is adsorbed on PEA surfaces when FN and $V N$ are competitively adsorbed, and a more interconnected $\mathrm{FN}$ network is formed as compared to solutions containing the same amount of FN and no VN. Moreover, the presence of $\mathrm{VN}$ during $\mathrm{FN}$ adsorption is likely to provide higher mobility to 
the FN network, contributing to enhance cell adhesion and cell-mediated FN reorganization.

\section{4) Cell-mediated matrix remodeling at the nanoscale reveals a change in distribution of adsorbed fibronectin layer on PEA surfaces.}

Early matrix remodeling was investigated in serum-free conditions on substrates on which FN adopts different conformations. Surprisingly on PEA surfaces, where a FN network is formed, a change in the adsorbed FN layer both close to cells and in between cells- is observed by AFM at the nanoscale after cell adhesion. It seems that FN layer is remodeled in areas close to cells, whereas a denser FN network is observed in between cells.

Different hypotheses, which might explain cellular processes occurring in the first stages of cell adhesion on PEA surfaces, have been investigated. Concretely, collagen I secretion was investigated in order to explain the denser protein mesh observed far away from cells, since collagen I is synthesized by MC3T3-E1 cells when their differentiation takes place. However, as no traces of this protein were found in between cells, this hypothesis was excluded. Matrix degradation was also assessed on the different materials due to the lower FN density observed around cells on PEA surfaces. Nevertheless, no differences were found in the enzymatic activity of MMP2 and MMP9 on the different materials. Since the non-cytotoxicity of PEA surfaces was also verified, other approaches such as the matrix remodeling by other matrix metalloproteinases or endocytosis of the protein should be investigated to further investigate this phenomenon. 

Annex 



\section{Annex: AFM images of fibronectin conformation and cell morphology in liquid environment}

Seeking to approach the physiological conditions in which biological molecules are found in vivo, preliminary studies of the fibronectin conformation and morphology of different cells at the molecular scale were performed by AFM in liquid environment.

Figure 8.1 shows, at different scales, the morphology of MC3T3-E1 cells on FNcoated PEA surfaces. In Figure 8.2, distribution of FN adsorbed on PEA surfaces at different concentrations and visualized by AFM in both air and liquid environment is observed. 

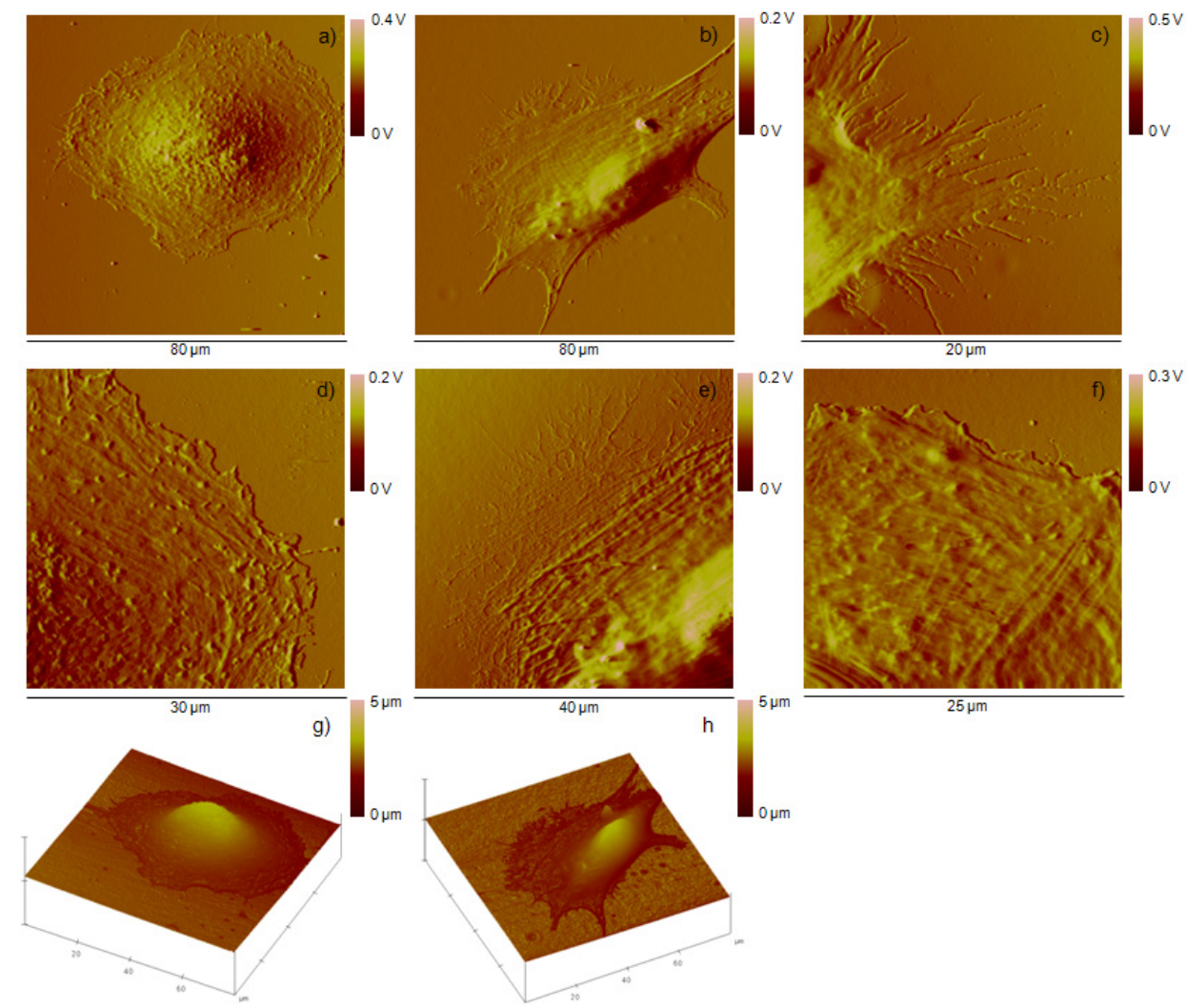

$25 \mu \mathrm{m}$

Figure 8.1 Morphology of MC3T3-E1 osteoblast-like cells on FN-coated PEA surfaces at 20 $\mu \mathrm{g} / \mathrm{ml}$, as observed by AFM amplitude images (a-f) in liquid environment. Two different cells are observed in a,b images and, at lower scale, a detail of cell cytoskeleton shows the actin filaments ( $d-e)$. The cells $3 D$ reconstruction is observed in the bottom of the figure $(g-h)$. Part of the cytoskeleton of other different cells is observed in c,f images. 

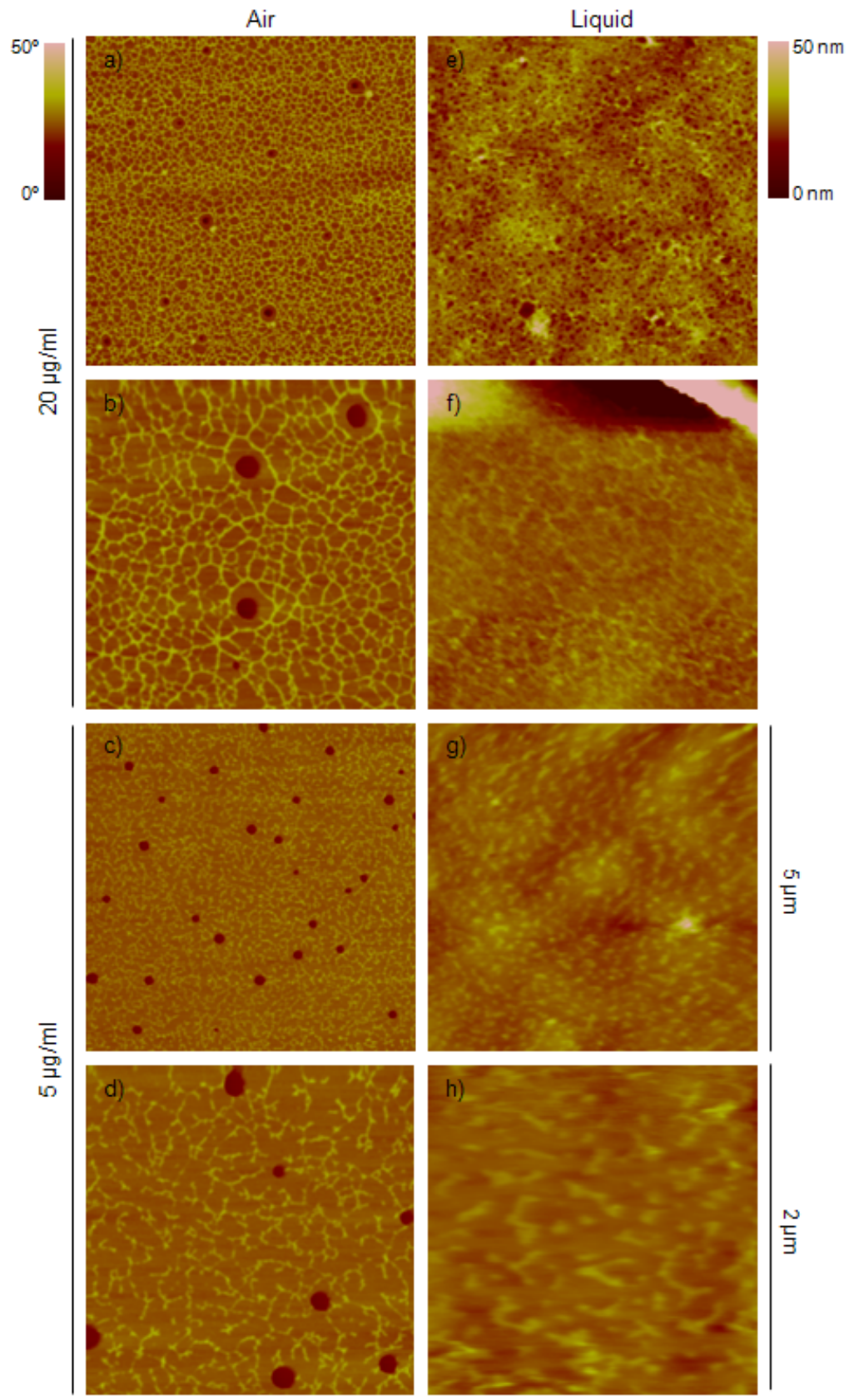

Figure 8.2 Conformation of the FN adsorbed on PEA surfaces at different concentrations, as observed by AFM images in air (a-d) and liquid (e-h) environment, at different scales. 
When $\mathrm{FN}$ is adsorbed on PEA surfaces from a protein solution of $20 \mu \mathrm{g} / \mathrm{ml}$, protein images obtained by AFM under physiological conditions support the presence of a FN network on this material, similar to those obtained in air. A less interconnected FN network is observed in both environments when $\mathrm{FN}$ is adsorbed at $5 \mu \mathrm{g} / \mathrm{ml}$.

However, AFM under liquid conditions presents problems of stability, which makes it more difficult to visualize adsorbed proteins, thus FN network is less clearly observed under these conditions. 


\section{Glossary}

$\begin{array}{ll}\text { AFM } & \text { Atomic Force Microscopy } \\ \text { A }_{0} & \text { Free oscillation amplitude of the AFM cantilever } \\ \text { A }_{\text {sp }} & \text { Set point amplitude of the AFM cantilever } \\ \text { BSA } & \text { Bovine Serum Albumin } \\ \text { Col } & \text { Collagen } \\ \text { DAPI } & \text { 4',6-diamidino-2-phenylindole } \\ \text { DMA } & \text { Dynamic Mechanical Analysis } \\ \text { DMEM } & \text { Dulbecco's Modified Eagle Medium } \\ \text { DPBS } & \text { Dulbecco's Phosphate Buffered Saline } \\ \text { ECM } & \text { Extracellular matrix } \\ \text { FN } & \text { Fibronectin }\end{array}$

HEPES (4-(2-hydroxyethyl)-1-piperazineethanesulfonic acid)

${ }^{125}$-FN FN labeled with $I^{125}$

MMP Matrix metalloproteinase

MSCs Mesenchymal stem cells

PAGE Polyacrylamide gel electrophoresis

PBA Poly (butyl acrylate)

PEA Poly (ethyl acrylate) 
PHA Poly (hexyl acrylate)

pl Isoelectric point

PLLA Poly (L-lactic acid)

PMA Poly (methyl acrylate)

PS Polystyrene

$\mathrm{Ra} \quad$ Mean roughness

SDS Sodium Dodecyl Sulfate

$\mathrm{T}_{\mathrm{g}} \quad$ Glass transition temperature

VN Vitronectin

WB Western Blot

WCA Water contact angle 


\section{Publications}

1. Poly(L-lactide) substrates with tailored surface chemistry by plasma copolymerization of acrylic monomers.

Cristina González García, Llorenç Latorre Ferrus, David Moratal, Manuel Monleón Pradas, Manuel Salmerón Sánchez

Plasma Processes and Polymers 6, 190-198 (2009)

2. Biological activity of substrate-induced fibronectin network: Insight into the third dimension through electrospun fibers.

Dencho Gugutkov, Cristina González-García, José Carlos Rodríguez Hernández, George Altankov, Manuel Salmerón-Sánchez.

Langmuir 25, 10893-10900 (2009)

3. Effect of nanoscale topography on fibronectin adsorption, focal adhesion size and matrix organization.

Cristina González-García, Susana R. Sousa, David Moratal, Patricia Rico, Manuel Salmerón-Sánchez.

Colloids and Surfaces B: Biointerfaces 77, 181-190 (2010)

4. Molecular assembly and biological activity of a recombinant fragment of fibronectin (FNIII 7-10 ) on poly(ethyl acrylate).

Patricia Rico, Cristina González-García, Timothy A. Petrie, Andrés J. García, Manuel Salmerón-Sánchez.

Colloids and Surfaces B: Biointerfaces 78, 310-316 (2010)

5. Vitronectin activity on polymer substrates with controlled -OH density.

Georgi Toromanov, Cristina González-García, George Altankov, Manuel Salmerón-Sánchez.

Polymer 51, 2329-2336 (2010)

6. Subtle variations in polymer chemistry modulate substrate stiffness and fibronectin activity.

Nayrim Brizuela Guerra*, Cristina González-García*, Virginia Llopis, José Carlos Rodríguez Hernández, David Moratal, Patricia Rico, Manuel Salmerón-Sánchez.

('These two authors contributed equally to this work)

Soft Matter 6, 4748-4755 (2010). 
7. Different assembly of type IV collagen on hydrophilic and hydrophobic substrata alters endothelial cells interaction.

N. Miranda Coelho, C. González-García, J. A. Planell, M. SalmerónSánchez, G. Altankov.

European Cells and Materials 19, 262-272 (2010)

8. Fibronectin distribution on demixed nanoscale topographies.

M. Pérez Garnes , C. González-García*, D. Moratal, P. Rico, M. SalmerónSánchez.

International Journal of artificial organs 34, 54-63 (2011)

('These two authors contributed equally to this work)

9. Fibrinogen organization at the cell-material interface directs endothelial cell behavior.

D. Gugutkov, C. González-García, G. Altankov, M. Salmerón-Sánchez. Journal of bioactive and compatible polymers 26, 375-387 (2011)

10. Arrangement of Type IV Collagen on $\mathrm{NH} 2$ and $\mathrm{COOH}$ Functionalized Surfaces.

N.M. Coelho, C. González-García, G. Altankov, M. Salmerón-Sánchez.

Biotechnology and bioengineering 108, 3009-3018 (2011)

11. Arrangement of Type IV Collagen and Laminin on Substrates with Controlled Density of-OH Groups.

N.M. Coelho, C. González-García, G. Altankov, M. Salmerón-Sánchez

Tissue Engineering Part A 17, 2245-2257 (2011).

12. Surface mobility regulates skeletal stem cell differentiation.

C. González-García, D. Moratal, R.C. Oreffo, M.J. Dalby, M. SalmerónSánchez

Integrative Biology 4, 531-539 (2012)

13. Material-driven fibronectin fibrillogenesis.

M. Cantini, C. González-García, V. Llopis-Hernández, M. SalmerónSánchez. Protein at Interfaces III; T. Horbett, J. Brash, W. Norde, eds.; American Chemical Society. Washington DC. In press.

14. Focal adhesion kinase in cell-materials interactions.

C. González-García, M. Salmerón-Sánchez, A.J. García.

Polymers in Regenerative Medicine: Biomedical Applications from Nano- to Macro Structures. John Wiley \& Sons. In press. 


\section{Acknowledgements}

I would like to show my gratitude to all those with whom I have shared these last five years, and who have helped me, in one way or another, to get to this moment.

First of all, I would like to express my most sincere thanks to my thesis supervisor Manuel Salmerón, for giving me the opportunity to develop my final degree project at the Center for Biomaterials and Tissue Engineering, and since then, encouraging me to continue this path and allowing me to develop my $\mathrm{PhD}$; for his guidance, his great support and dedication during these last years, and for trusting me and offering me such great opportunities. Thanks!

I would like to thank all the people at the Center for Biomaterials and Tissue Engineering; professors, technicians and students, for their help and support, for their advice, and for creating such a good workplace. Thanks to Gloria Gallego, for her support at the beginning of my Ph.D. and her help in the last years. Thanks a lot to all my colleagues and friends at the CBIT, especially to those who have shared these years so closely with me, for their friendship, their help and support, for their great encouragement during the writing period, for so many great times together inside and outside the lab, and for making me smile every day, even in the bad times...: Thanks to Miriam for always being there and for her great support; to Marco for encouraging me, even with the distance, and for his valuable help with English; to Harmony for all our conversations; to Pachi for her help and for teaching me everything about the biological experiments; to Virginia for her encouragement and support, even through those messages during the writing of this work; to Pepe for explaining me so many doubts about biological topics, and for his time and patience during the writing period; to Tati for her support, and for always having a time to talk to me; to Carmen for her cheerful character, and for her company in this last phase; to Myriam for her help and for caring of my health ;) Thanks to Manu and Nayrim for the time we worked together and for their contribution to this work; thanks to 
Joseca for his help and support during my first years at the CBIT, and to Elisa for increasing my curiosity about the culture lab and explaining me my first questions. And thanks to Lidia, Alex, Amparo B, Amparo G, Carmen, Gabriela, Cristina, Laura, María... for their help and for the good times that we spent together.

Thanks to the staff of the Microscopy Service at the Universitat Politècnica de València, for their guidance and help, especially to José Luis, for his advice and his company during those long afternoons of AFM...

The financial support of the Spanish Ministry of Science and Innovation through the projects DPI2010-20399-C04-03 and CICyT-MAT2009-14440-C0201, and my FPI fellowship BES-2008-007151, is kindly acknowledged; as well as the support of the Networking Biomedical Research Center (CIBER-BBN) and the Prince Felipe Research Centre.

I also would like to convey my gratitude to the professors responsible for my stays at other Research Centers during my Ph.D.: Prof. Susana Sousa, at the Instituto de Engenharia Biomédica in Porto; Prof. Matthew Dalby, at the Center for Cell Engineering in Glasgow; and Prof. George Altankov, at the Institute of Bioengineering of Catalonia in Barcelona; for allowing me to develop part of my work in their laboratories, for their help and valuable advice, and their support during my stays. Thanks to the people of the respective Centers, for their hospitality and support during those months away from home, especially to Susana Sousa for looking after me inside and outside the lab; to Joana for opening her home to me; to Nilza for sharing those long "days of radioactivity" with me; to Rebecca for her help and support; and thanks to Nuno, for devoting some of his time to my work during the last phase of his thesis.

Thanks to Mark and Aileen for their help with my English.

Thanks to my friends for their great support, especially to Andrea and Natalia, for always being there, despite the distance. 
Finalmente me gustaría agradecer de corazón a mis padres, por preocuparse tanto por mí, por su apoyo constante, su paciencia y su total dedicación y ayuda; a mi hermana Bea, por nunca dejar de escucharme y ayudarme tanto; y a mi hermano Luismi, por darme siempre tan buenos consejos. Y mi agradecimiento más especial a Jorge, por formar parte de mi vida, por estar a mi lado y animarme constantemente, gracias por cada momento...

$\mathrm{Y}$ a todas aquellas personas que no he nombrado y que de una forma u otra han contribuido a que este trabajo salga adelante. 